\title{
An Archaeological Survey of 307 Acres at Camp Swift, Bastrop County, Texas: 2003
}

\author{
David L. Nickels \\ Antonio Padilla \\ Raba Kistner \\ James E. Barrera \\ Center for Archaeological Studies \\ C. Britt Bousman \\ Department of Anthropology, Texas State University
}

Follow this and additional works at: https://scholarworks.sfasu.edu/ita

Part of the American Material Culture Commons, Archaeological Anthropology Commons, Environmental Studies Commons, Other American Studies Commons, Other Arts and Humanities Commons, Other History of Art, Architecture, and Archaeology Commons, and the United States History Commons

Tell us how this article helped you.

This Article is brought to you for free and open access by the Center for Regional Heritage Research at SFA ScholarWorks. It has been accepted for inclusion in Index of Texas Archaeology: Open Access Gray Literature from the Lone Star State by an authorized editor of SFA ScholarWorks. For more information, please contact cdsscholarworks@sfasu.edu. 
An Archaeological Survey of 307 Acres at Camp Swift, Bastrop County, Texas:

2003

\section{Creative Commons License}

(c) (1) (8)

This work is licensed under a Creative Commons Attribution-NonCommercial 4.0 International License 


\section{An Archaeological Survey of 307 Acres at} Camp Swift, Bastrop County, Texas: 2003

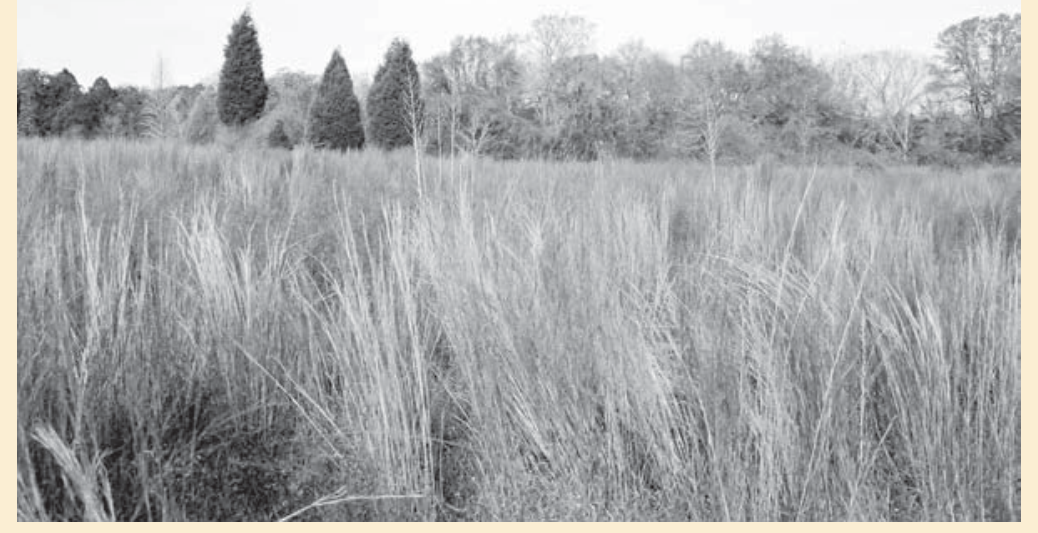

By David L. Nickels, Antonio Padilla, James E. Barrera and C. Britt Bousman

Principal Investigators: C. Britt Bousman and David L. Nickels 


\title{
An Archaeological Survey of $\mathbf{3 0 7}$ Acres at Camp Swift, Bastrop County, Texas: 2003
}

\author{
by \\ David L. Nickels, Antonio E. Padilla, and James E. Barrera \\ With a contribution by C. Britt Bousman
}

\author{
Principal Investigators \\ C. Britt Bousman \\ and David L. Nickels
}

Archaeological Studies Report No. 6

Center for Archaeological Studies

Texas State University-San Marcos

2005 
The following information is provided in accordance with the General Rules of Practice and Procedure, Title 13, Chapter 26, Texas Administrative Code:

1. Type of investigation: Intensive pedestrian survey with limited subsurface testing of prehistoric and historic archaeological sites

2. Project name: Archaeological Survey of 307 Acres at Camp Swift, Bastrop County, Texas: 2003

3. County: Bastrop

4. Principal Investigators: C. Britt Bousman and David L. Nickels

5. Name and location of sponsoring agency: The Adjutant General's Department of Texas, Directorate of Facilities and Engineering, Environmental Branch, Austin, Texas

6. Published by the Center for Archaeological Studies, Texas State University-San Marcos, 601 University Drive, San Marcos, Texas 78666 (2005)

Texas State University-San Marcos is a member of the Texas State University System Copyright (C) 2005 by Center for Archaeological Studies at Texas State University-San Marcos

All rights reserved.

No part of this book may be reproduced or utilized in any form or by any means, electronic or mechanical, including photocopying, recording or by any information storage and retrieval system without permission in writing.

For further information on this and other publications by the Center for Archaeological Studies, please contact:

Center for Archaeological Studies

Texas State University-San Marcos

601 University Drive

San Marcos, Texas 78666

www.txstate.edu/anthropology/cas/

Editors: Jessica Hurley, and Carole Leezer

Cover photography: Heavily wooded stream courses and grass-covered, rolling uplands are typical of the terrain and vegetation at Camp Swift.

Printed in the United States of America 


\section{Management Summary}

\section{Management Objectives}

The Texas Army National Guard conducts military training on Camp Swift, an approximately 11,500 acre tract in northern Bastrop County, Texas. As required by law, an environmental assessment of the area was conducted with pedestrian surveys beginning as early as 1979. The Adjutant General's Department of Texas (AGTX) was charged with oversight management of archaeological compliance for the Camp. The survey was undertaken to meet requirements under sections 106 and 110 of the National Historic Preservation Act (NHPA). Under Sections 106 and 110 of the NHPA, the protection of cultural resources is related to their eligibility for inclusion in the National Register of Historic Places (NRHP), which is in turn dependent on their NRHP significance as defined in 36 CFR Part 60. The National Historic Preservation Act Amendments of 1992 clarified Section 110 and directed federal agencies to establish preservation programs corresponding to their activities and effects on historic properties. Under Section 110 , federal agencies may evaluate the significance of cultural resources not currently threatened to assist with the development of preservation planning.

The purpose of the surveys was to identify cultural resources at Camp Swift and to provide the Texas National Guard with recommendations as to the eligibility of the sites for nomination to the National Register of Historic Places (NRHP). In the case of prehistoric sites, significance is often based on Criterion D of the National Historic Preservation Act (NHPA) as defined by the National Park Service in 36 CFR 60. The significance of a site under Criterion D, and therefore its eligibility for listing on the NHRP, is based on its having yielded information important in history or prehistory, or on its having the potential to yield such information in the future. The question of what information is important, a point not addressed in the NRHP, is a function of research questions or developed historic contexts.

\section{Contracting Parties}

The Center for Archaeological Studies (CAS) of Texas State University-San Marcos contracted with the sponsoring agency, the Texas Army National Guard. The investigations were conducted under interagency cooperative agreement number TX 01-ENV-29 401-03-3872. C. Britt Bousman and David L. Nickels served as co-principal investigators for the project. David L. Nickels directed the daily field operations.

\section{Scope of Work}

The purpose of this survey was to identify prehistoric and historic cultural resources in a 307 acre portion of Camp Swift and assess the sites as to their eligibility for listing on the National Register of Historic Places. 


\section{Summary of Results and Site Significance}

In September through November 2003, the Center for Archaeological Studies (CAS), Texas State University- San Marcos conducted a Phase I archaeological survey on 307 acres at Camp Swift, Bastrop County, Texas. Texas Historical Commission standards for Phase I pedestrian surveys and site shovel tests were exceeded. CAS personnel excavated 668 shovel tests and nine backhoe trenches. Artifacts recovered from shovel tests and the surface are curated at the Texas Archeological Research Laboratory. A total of 11 new archaeological sites with nine prehistoric, and four historic components were discovered. In addition, nine isolated artifacts were recorded. Five of the nine prehistoric components were not eligible to be listed on the National Register of Historic Places, and no further work recommended. The remaining four prehistoric sites require additional investigations to determine their eligibility. Three of the four historic components were assessed as not eligible for listing on the National Register for Historic Places (NRHP), and the fourth historic component warrants additional investigations.

\section{Prehistoric Sites}

Prehistoric sites were judged as eligible for listing on the NRHP based on the following criteria:

High potential: Sites with clear high integrity. Sites that shovel test results indicate a pattern of stratified deposits with temporally distinct assemblages, have an excellent potential for buried, intact deposits and/or datable features, or otherwise have the potential to address research issues.

Moderate potential: Sites with high to moderate integrity. Sites that shovel test results have not clearly demonstrated high integrity, but with further testing potentially could yield buried, intact deposits with distinct artifact assemblages and/or datable features, and otherwise have the potential to address research issues.

Minimal potential: Little or no integrity sites. Sites upon which shovel test results have produced no evidence of intact deposits, sites with clearly mixed assemblages, and/or have otherwise been disturbed so that there is little or no potential for providing credible information.

As the current project involved excavation of shovel tests and surface observations, recommendations required to be made by CAS according to the survey contract were as follows: 1) eligible for listing on the National Register of Historic Places, 2) not eligible for listing on the National Register of Historic Places, or 3) requires further investigation beyond the scope of this survey project.

Four prehistoric site components and/or distinct prehistoric sites were assessed as having little or no integrity, likewise having minimal research potential, and thus recommended as not eligible for the National Register of Historic Places. These sites are 41BP662, 41BP664, 41BP669 and 41BP670. 
Five prehistoric site components were assessed as demonstrating moderate integrity, and potentially capable of having high research potential; thus we believe further investigation beyond the scope of this inventory survey are required before recommendations can be made regarding their eligibility for nomination to the National Register of Historic Places. These sites are 41BP665, 41BP666, 41BP667, 41BP671 and 41BP672.

No prehistoric site components and/or distinct prehistoric sites were assessed as demonstrating high integrity or displaying high research potential. However, we believe further investigations beyond the scope of this project are required before recommendations can be made regarding their eligibility for nomination to the National Register of Historic Places.

\section{Historic Sites}

Department of the Interior Regulations 36 CFR 60 provide for the registration of historic properties on the NRHP that:

A) are associated with events that have made a significant contribution to the broad patterns of our history; or

B) are associated with the lives of persons significant in our past; or

C) embody the distinctive characteristics of a type, period, or method of construction, or that represent the work of a master, or that possess high artistic values, or that represent a significant and distinguishable entity whose components may lack individual distinction; or

D) have yielded, or may yield, information important in prehistory or history.

In addition, the integrity of individual properties should be evaluated in relation to like properties with a similar cultural theme, within the same geographical area, and generally within the same time frame. For this study, historic properties were evaluated based on Criterion A: Agriculture, Criterion B: Important Individuals, Criterion C: Architecture, and Criterion D: Research Potential.

Three of the four identified historic component or sites within the boundaries of the survey area are notbelieved to be eligible for listing on the National Register of Historic Places, and no further investigations are recommended. These are 41BP663, 41BP668 and 41BP670. The historic component at 41BP666 has a moderate research potential and further research is required to determine if it may be eligible for listing on the National Register of Historic Places. 


\section{Table of Contents}

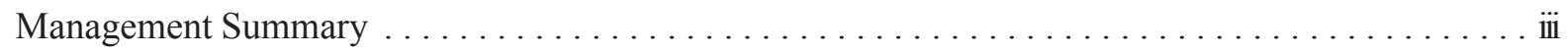

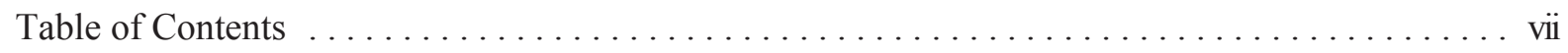

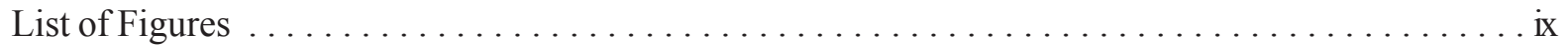

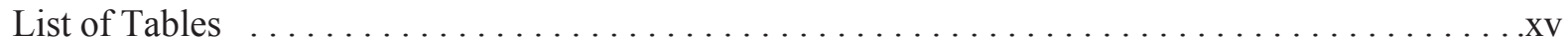

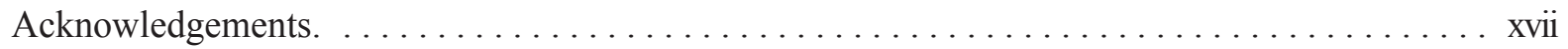

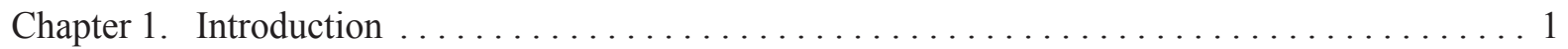

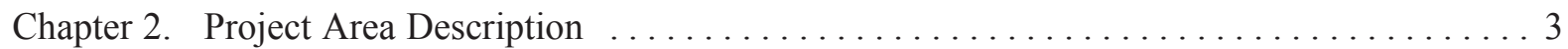

Chapter 3. Previous Archaeological Investigations $\ldots \ldots \ldots \ldots \ldots \ldots \ldots \ldots \ldots \ldots \ldots \ldots \ldots$

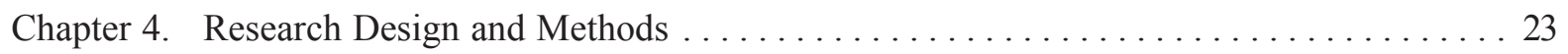

Chapter 5. Site Descriptions, Analysis, Recommendations, and Isolated Finds . . . . . . . . 33

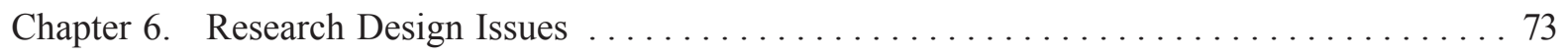

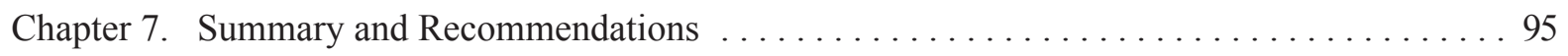

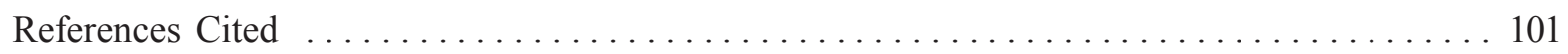

Appendix A. Shovel Test Data . . . . . . . . . . . . . . . . . . . . . . . . 119

Appendix B. Combined USGS Map Showing Site Locations . . . . . . . . . . . inside back cover 


\section{List of Figures}

1-1. Camp Swift is located in north central Bastrop County, Texas $\ldots \ldots \ldots \ldots \ldots \ldots \ldots 1$

2-1. Bastrop County is situated approximately $30 \mathrm{~km}$ east of the Balcones

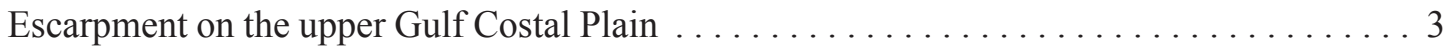

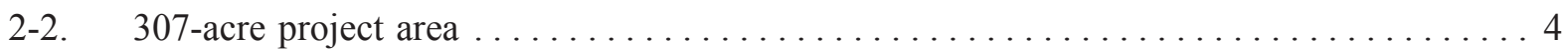

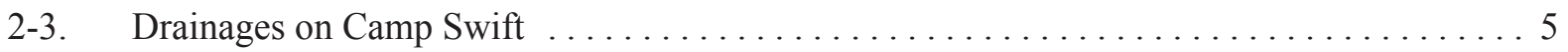

2-4. Camp Swift is located within the Post Oak Savannah vegetation region $\ldots \ldots \ldots \ldots \ldots 7$

2-5. American Beautyberry (Callicarpa americana) with developed dark red berries, grow within the well-drained, wooded areas in the uplands

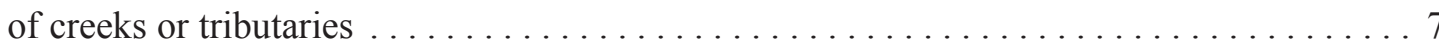

2-6. Heavily wooded stream divides and grass-covered, rolling uplands are typical of the terrain and vegetation at Camp Swift $\ldots \ldots \ldots \ldots \ldots \ldots$.

2-7. Camp Swift lies within the Texan biotic province $\ldots \ldots \ldots \ldots \ldots \ldots \ldots \ldots$

4-1. Project map showing designated survey areas for management

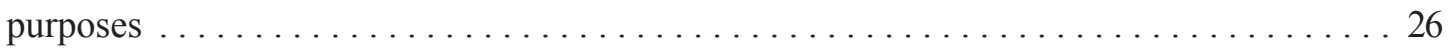

4-2. Areas of dense brush required two individuals to walk transects $\ldots \ldots \ldots \ldots \ldots \ldots$

4-3. Project map showing areas of probability and shovel test locations $\ldots \ldots \ldots \ldots \ldots 27$

4-4. Collecting shovel test data in Area C; all sediments were screened through

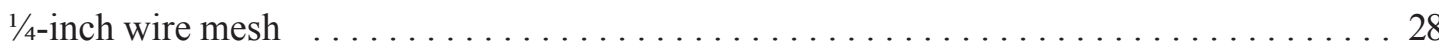

4-5. Armando Salinas conducted the trenching operations for the project $\ldots \ldots \ldots \ldots 28$

4-6. Monitoring backhoe trench excavations adjacent to Big Sandy Creek $\ldots \ldots \ldots \ldots \ldots 29$ 
5-1. 41BP662 lies on a terrace of Big Sandy Creek; facing southwest $\ldots \ldots \ldots \ldots \ldots 4$

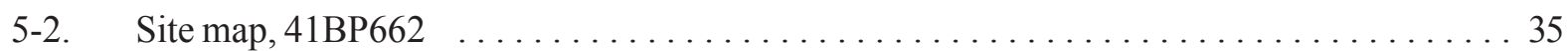

5-3. 41BP664 lies on an old, upper terrace and sidelope; facing west $\ldots \ldots \ldots \ldots \ldots$

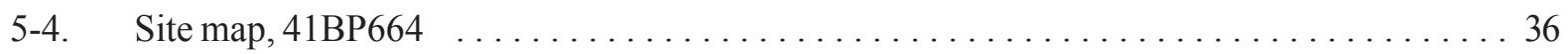

5-5. Melissa Lehman collecting information at a shovel test location on 41BP665, situated on an upper terrace and sideslope; facing northwest. . . . . . . 37

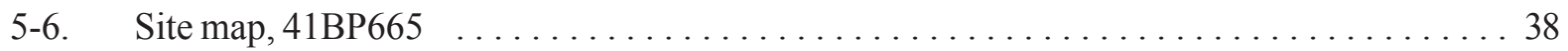

5-7. 41BP666 covers a broad upland ridge and sideslope between two drainages; facing northeast $\ldots \ldots \ldots \ldots \ldots \ldots \ldots \ldots \ldots \ldots$

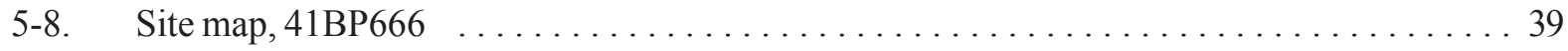

5-9. Distribution of all chipped stone artifacts

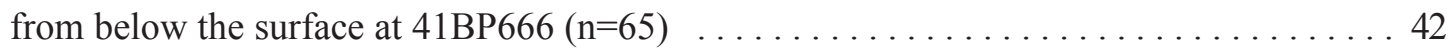

5-10. Distribution of all chipped stone within the upper $30 \mathrm{~cm}$ at 41BP666 $(\mathrm{n}=29)$

5-11. Distribution of all chipped stone recovered from below $30 \mathrm{~cm}$ at 41BP666 $(\mathrm{n}=38)$

5-12. Distribution of all fire-cracked rocks greater than 1" in size at 41BP666

5-13. 41BP667 is a small prehistoric open campsite situated on a gradually sloping terrace adjacent to a densely wooded area along Big Sandy Creek; facing southwest . . . 44

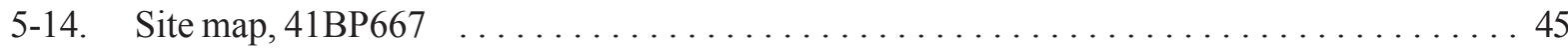


5-15. A petrified wood chopping tool was found on the surface at $41 \mathrm{BP} 667$

5-16. 41BP669 is a small prehistoric open campsite situated on a gradually sloping terrace adjacent to Big Sandy Creek; facing south $\ldots \ldots \ldots \ldots \ldots \ldots \ldots$. . . . 46

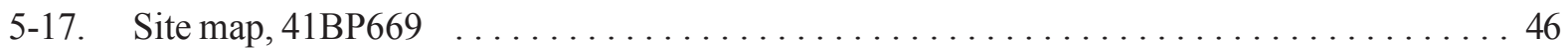

5-18. 41BP670 consists of an ephemeral scatter of chipped stone tools and debitage in a historic quarry with Uvalde gravels exposed; facing northwest . . . . . . . 48

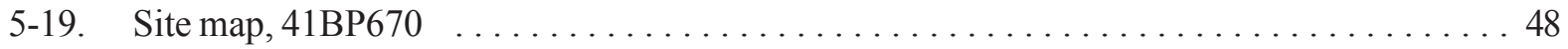

5-20. A uniface and one of the bifaces found on the surface at $41 \mathrm{BP} 670 \ldots \ldots \ldots \ldots \ldots$

5-21. 41BP671 is a large open campsite buried in this heavily wooded area;

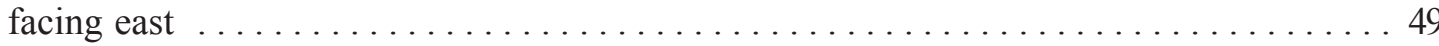

5-22. Drainage cutbank adjacent to 41BP671; facing southeast $\ldots \ldots \ldots \ldots \ldots \ldots \ldots \ldots$

5-23. Shovel tests on "Island" formed when stream shifted at 41BP671;

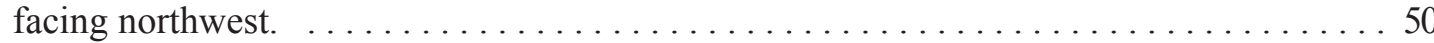

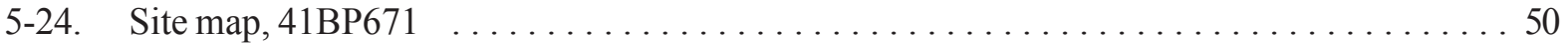

5-25. 41BP672 is situated on an upper terrace near Big Sandy Creek;

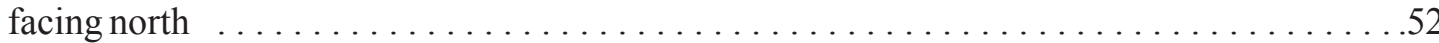

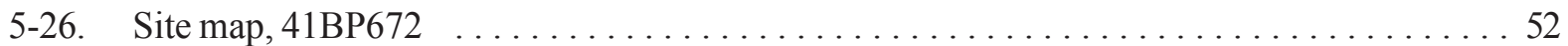

5-27. Site 41BP663; the bulldozed house that may have belonged to the Vonkochneritz family was in the middle of this thicket; facing northeast $\ldots \ldots \ldots \ldots \ldots \ldots \ldots \ldots 4$

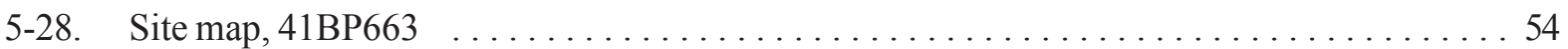


5-29. Selected artifacts collected from shovel tests at 41BP663; clockwise from top: square nails, whiteware, stoneware, amber glass

5-30. This was the site of Noel Branton's house at 41BP666;

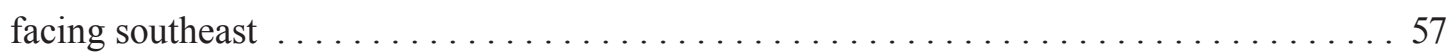

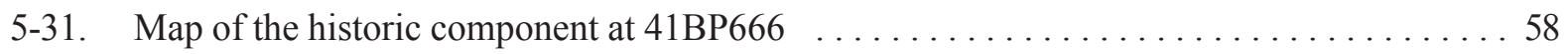

5-32. Chimney base at Noel Branton's house, 41BP666; facing southeast $\ldots \ldots \ldots \ldots \ldots$

5-33. Gray, salt glazed, red bricks found on the surface at 41BP666, presumably from a pottery kiln

5-34. Broken, 3.785 liter stoneware crock found on the surface at 41BP666

5-35. Clear glass condiment bottle found on the surface at 41BP666 was produced in either 1917 or 1927 by the Owens Bottle Company. 61

5-36. Jimmy Barrera in trench beside earthen berm at 41BP666;

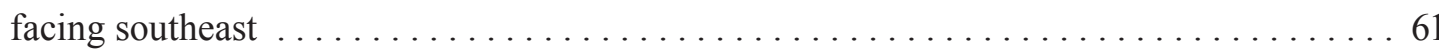

5-37. Earthen berm with wooden door and cedar fence posts at 41BP666;

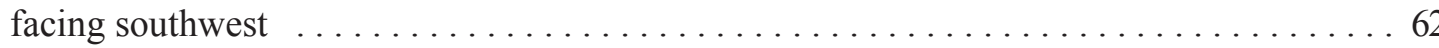

5-38. 41BP668 lies at the base of a slope, on an old field; facing north $\ldots \ldots \ldots \ldots \ldots$

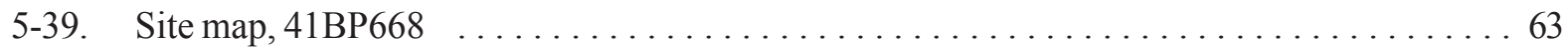

5-40. Jimmy Barrera recording sandstone structure remains at 41BP670;

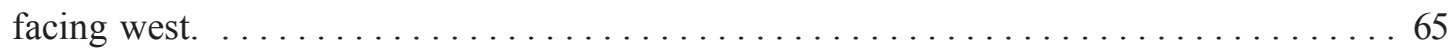

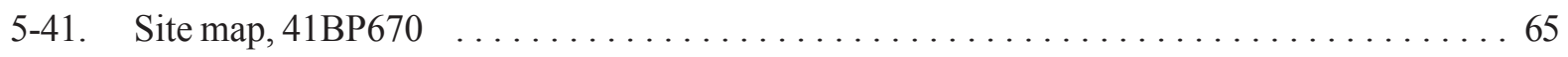


5-42. Sandstone structural remains at 41BP670; facing southeast $\ldots \ldots \ldots \ldots \ldots \ldots \ldots \ldots$

5-43. Sketched plan view of sandstone structural remains at 41BP670 $\ldots \ldots \ldots \ldots \ldots \ldots 6$

5-44. Soil susceptibility values collected from shovel probe samples around the structural walls at 41BP670 . . . . . . . . . . . . . . . . . . . . . 67

5-45. $\mathrm{pH}$ values collected from shovel probe samples around the

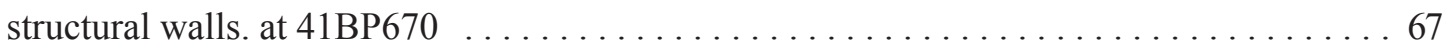

5-46. Remains of the dam on the creek at 41BP670; facing west $\ldots \ldots \ldots \ldots \ldots \ldots$

5-47. This dark brown whiskey bottle neck dating to between 1880 and 1900 was found in the creek bottom above the dam at 41BP670

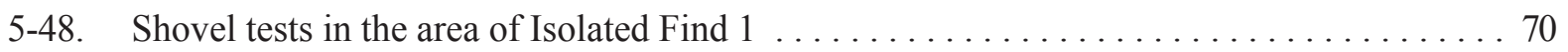

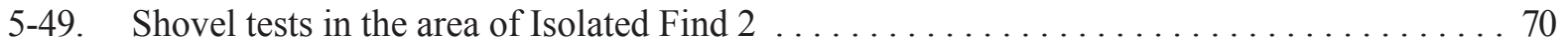

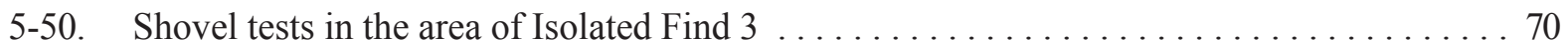

5-51. Shovel tests in the area of Isolated Find $4 \ldots \ldots \ldots \ldots \ldots \ldots \ldots \ldots \ldots \ldots \ldots \ldots \ldots \ldots \ldots \ldots$

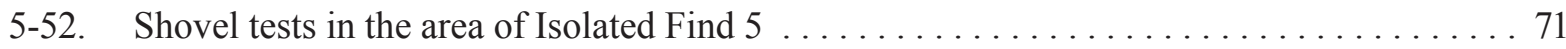

5-53. Shovel tests in the area of Isolated Find $6 \ldots \ldots \ldots \ldots \ldots \ldots \ldots \ldots \ldots \ldots \ldots \ldots \ldots \ldots \ldots$

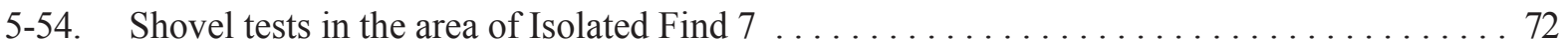

6-1. Temporal periods represented by diagnostic artifacts $\ldots \ldots \ldots \ldots \ldots \ldots \ldots \ldots$

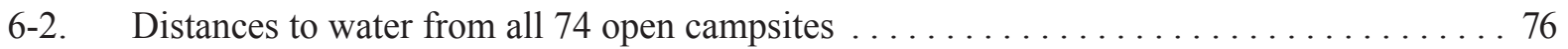

6-3. Distance to water from open campsites with diagnostic artifacts $\ldots \ldots \ldots \ldots \ldots \ldots 77$ 
6-4. Distances to lithic procurements sites from all open campsites on

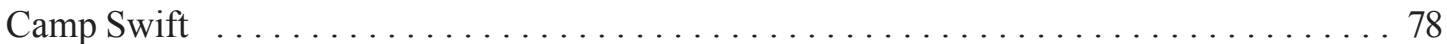

6-5. Pie chart showing the percentages of open campsites that are

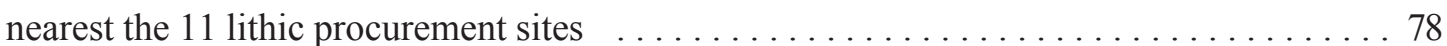

6-6. Late Prehistoric campsites and their distances from the nearest

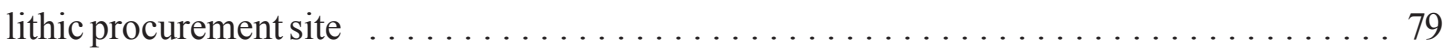

6-7. Magnetic susceptibility $\left(\mathrm{Xm} 10^{-6}\right)$ and $\mathrm{pH}$ values for Backhoe Trench $1 \ldots \ldots \ldots$

6-8. Magnetic susceptibility $\left(\mathrm{Xm} 10^{-6}\right)$ and $\mathrm{pH}$ values for Backhoe Trench $2 \ldots \ldots \ldots$

6-9. Magnetic susceptibility $\left(\mathrm{Xm} 10^{-6}\right)$ and $\mathrm{pH}$ values for Backhoe Trench $3 \ldots \ldots \ldots$

6-10. Magnetic susceptibility $\left(\mathrm{Xm} 10^{-6}\right)$ and $\mathrm{pH}$ values for Backhoe Trench $4 \ldots \ldots \ldots$

6-11. Magnetic susceptibility $\left(\mathrm{Xm} 10^{-6}\right)$ and $\mathrm{pH}$ values for Backhoe Trench $5 \ldots \ldots \ldots$

6-12. Magnetic susceptibility $\left(\mathrm{Xm} 10^{-6}\right)$ and $\mathrm{pH}$ values for Backhoe Trench $6 \ldots \ldots \ldots 7$

6-13. Magnetic susceptibility $\left(\mathrm{Xm} 10^{-6}\right)$ and $\mathrm{pH}$ values for Backhoe Trench $7 \ldots \ldots \ldots 8$

6-14. Magnetic susceptibility $\left(\mathrm{Xm} 10^{-6}\right)$ and $\mathrm{pH}$ values for Backhoe Trench $8 \ldots \ldots \ldots$

6-15. Magnetic susceptibility $\left(\mathrm{Xm} 10^{-6}\right)$ and $\mathrm{pH}$ values for Backhoe Trench $9 \ldots \ldots \ldots$

6-16. Decreasing acreage of farmsteads on Camp Swift $\ldots \ldots \ldots \ldots \ldots \ldots \ldots \ldots \ldots \ldots$ 


\section{List of Tables}

2-1. Soils most prominent on Camp Swift $\ldots \ldots \ldots \ldots \ldots \ldots \ldots \ldots \ldots \ldots \ldots \ldots \ldots \ldots \ldots \ldots \ldots \ldots \ldots$

2-2. Common vegetation within various plant communities on Camp

Swift (Vera 1978; adapted from Skelton and Freeman 1979) . . . . . . . . . . . . . 6

2-3. Mammals expected to either visit or inhabit the project area $\ldots \ldots \ldots \ldots \ldots \ldots$

2-4. Reptiles expected to either visit or inhabit the project area $\ldots \ldots \ldots \ldots \ldots \ldots \ldots$

2-5. Birds expected to either visit or inhabit the project area $\ldots \ldots \ldots \ldots \ldots \ldots$

3-1. Cultural chronologies pertinent to the Camp Swift area $\ldots \ldots \ldots \ldots \ldots \ldots \ldots \ldots \ldots$

5-1. Previously recorded sites either within or periphery to the current

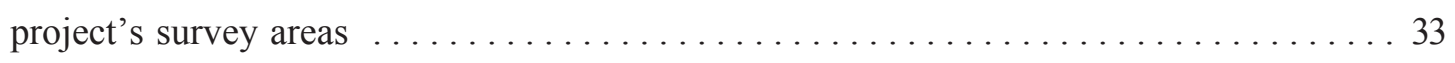

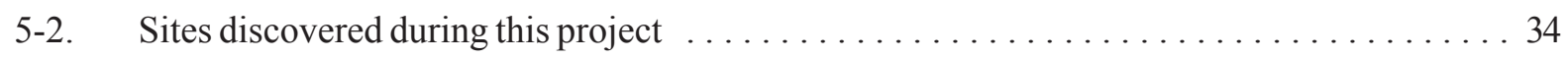

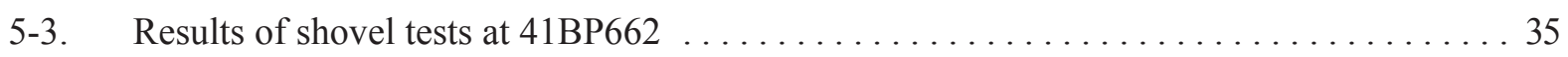

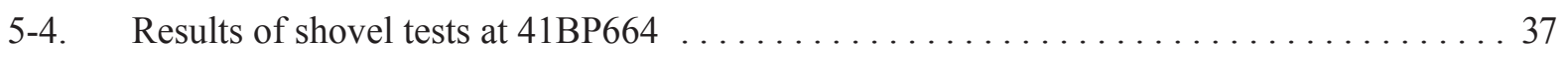

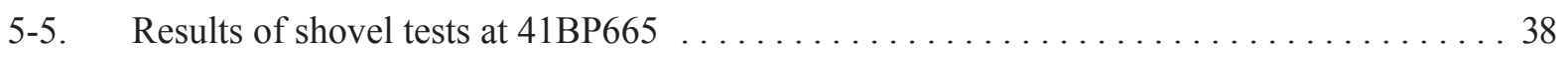

5-6. Totals of cultural remains recovered from shovel tests at $41 \mathrm{BP} 666 \ldots \ldots \ldots \ldots \ldots$

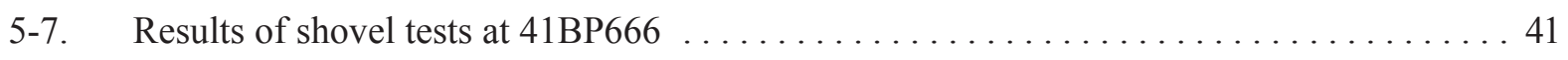

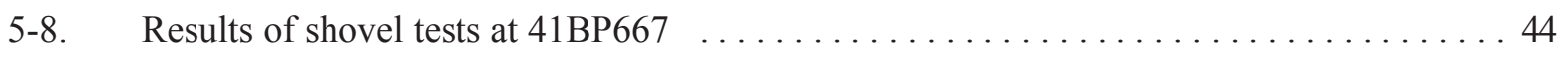

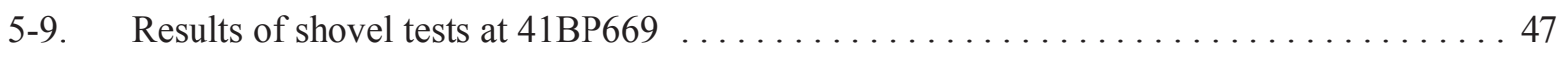




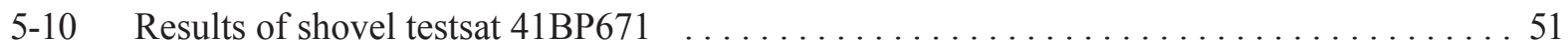

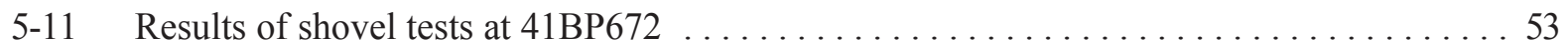

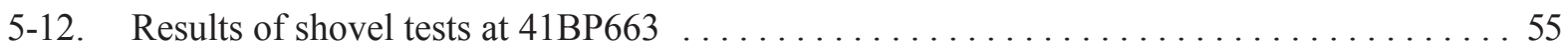

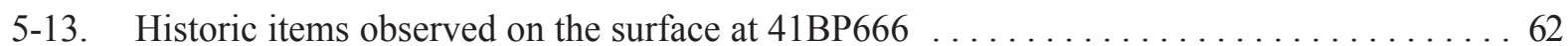

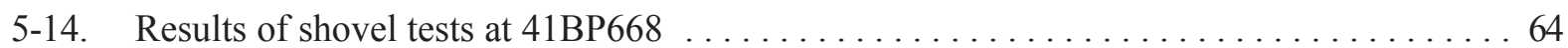

6-1. Prehistoric component types documented at Camp Swift $\ldots \ldots \ldots \ldots \ldots \ldots \ldots \ldots$

6-2. Diagnostic artifacts recovered from Camp Swift sites $\ldots \ldots \ldots \ldots \ldots \ldots \ldots \ldots \ldots$

6-3. Distances of open campsites with diagnostic artifacts to water $\ldots \ldots \ldots \ldots \ldots \ldots \ldots 77$

6-4. Depths of soil as determined by shovel tests $\ldots \ldots \ldots \ldots \ldots \ldots \ldots \ldots \ldots \ldots$

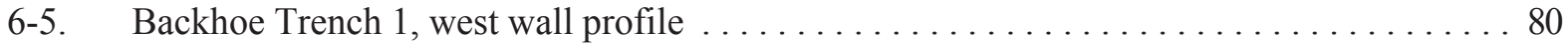

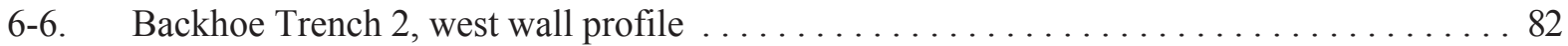

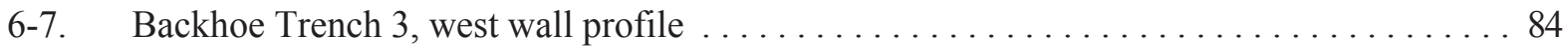

6-8. Backhoe Trench 4, southwest wall profile $\ldots \ldots \ldots \ldots \ldots \ldots \ldots \ldots \ldots \ldots \ldots \ldots$

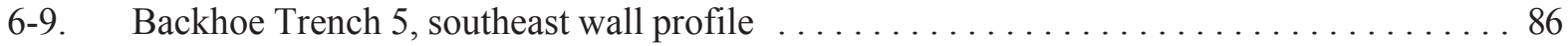

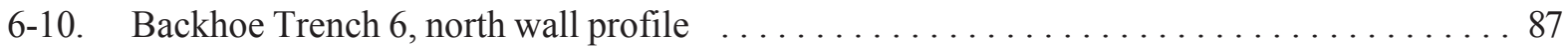

6-11. Backhoe Trench 7, northeast wall profile $\ldots \ldots \ldots \ldots \ldots \ldots \ldots \ldots \ldots \ldots \ldots \ldots$

6-12. Backhoe Trench 8, southeast wall profile $\ldots \ldots \ldots \ldots \ldots \ldots \ldots \ldots \ldots \ldots \ldots$ 
6-13. Backhoe Trench 9, southeast wall profile $\ldots \ldots \ldots \ldots \ldots \ldots \ldots \ldots \ldots \ldots \ldots \ldots$

6-14. Early developments in the Camp Swift area $\ldots \ldots \ldots \ldots \ldots \ldots \ldots \ldots \ldots \ldots \ldots$

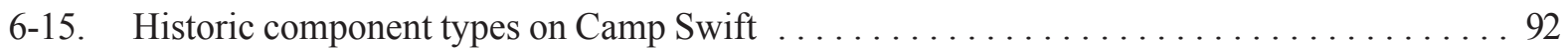

6-16. Developments on Camp Swift relative to the surrounding area $\ldots \ldots \ldots \ldots \ldots \ldots$

7-1. Prehistoric site components assessed as having moderate integrity $\ldots \ldots \ldots \ldots$ 


\section{Acknowledgements}

The authors wish to thank Ms. Shellie Sullo and Ms. Kristen Wenzel, the previous and current Cultural Resource Managers for the Texas National Guard, who made this project possible and were extremely helpful throughout every phase. Also Master Sergeant Robert West, the Camp Swift Facility Manager, coordinated with us almost daily to ensure our testing project did not conflict with military training requirements. Throughout the project, co-principle Investigator Britt Bousman was extremely supportive and enthusiastic, and enjoined us in many stimulating discussions regarding site formation processes within the sandy mantle. The fieldwork was conducted by Project Archaeologist David Nickels, with Jimmy Barrera, Melissa Lehman, and Antonio Padilla as crew members. The lithic analysis was conducted by Jimmy Barrera, Linda Hodges, Melissa Lehman, and Antonio Padilla. Ray Umsheid and Matt Melancon fine-tuned the maps and illustrations for this publication. Jessica Hurley, and Carole Leezer were the co-

editors. Finally, under the direction of Connie Gibson, the artifacts, photographs and written documents were prepared for curation by Jimmy Barrera, Antonio Padilla, and Shawn Soucie. 


\section{Chapter 1}

\section{INTRODUCTION}

David L. Nickels

This report documents an archaeological survey of 307 acres at Camp Swift, in north-central Bastrop County, Texas (Figure 1-1). Camp Swift is owned by the Texas Army National Guard office of Adjutant General (hereinafter referred to as AGTX).

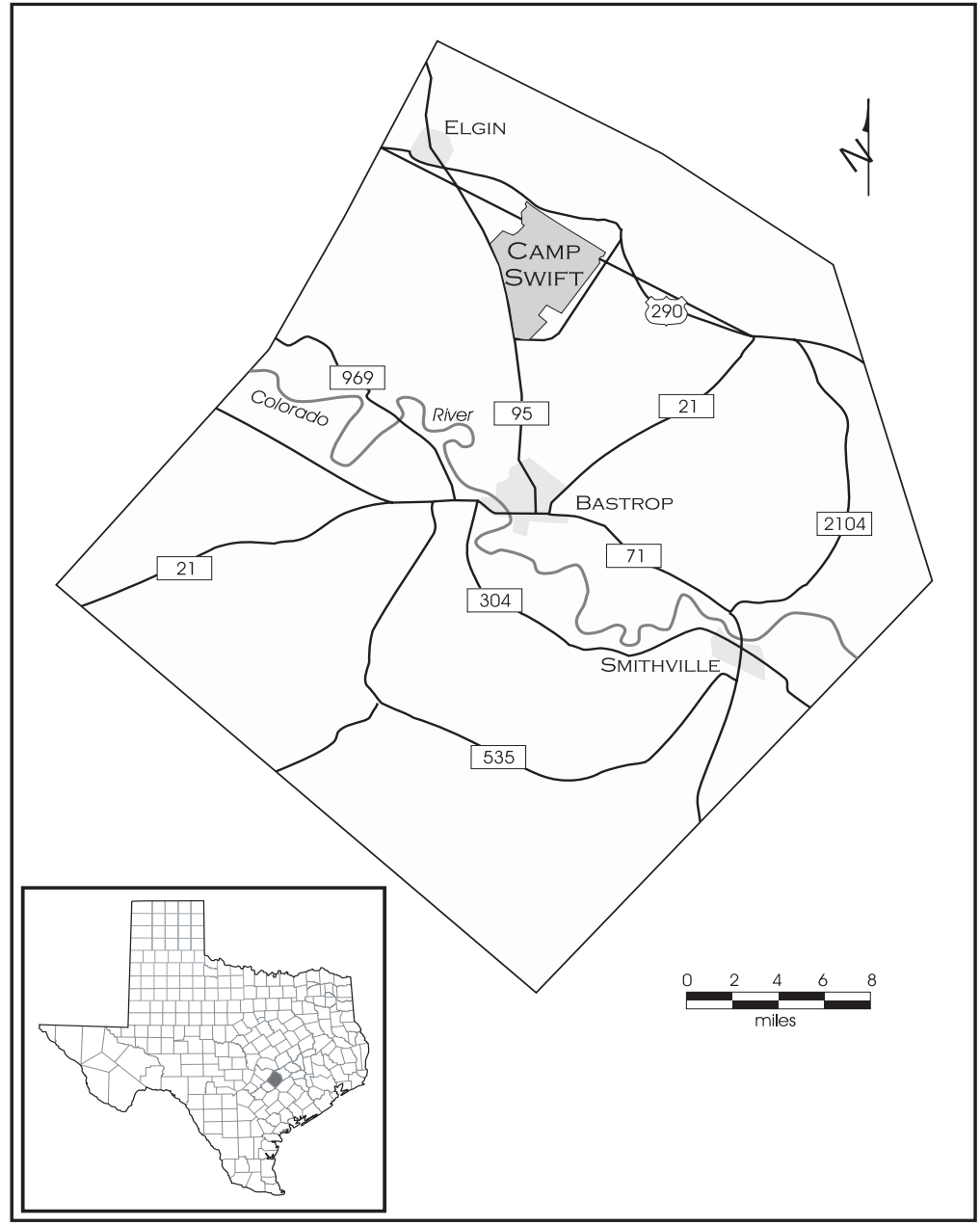

Figure 1-1. Camp Swift is located in north central Bastrop County, Texas.
The entire Camp now encompasses approximately 11,500 acres, reduced from its WWII era 52,982 acres. Camp Swift's headquarters is located north of Bastrop and south of Elgin. Members of all military services, several civilian law enforcement agencies, and other state entities use the land for tracked and wheeled vehicle maneuvers, dismounted (on-foot) military training, and weapons firing.

With the completion of this 307-acre project, all 11,500 acres at Camp swift have now been archaeologically surveyed. A total of 11 previously unrecorded sites were documented during this project, bringing the total number of sites on Camp Swift to 181. The surveys and additional archaeology investigations at Camp Swift are discussed in Chapter 3. Within the 307-acre project area, 668 shovel tests and nine backhoe trenches were dug in a systematic pattern to find sites, to define their boundaries, and to further evaluate site integrity. All prehistoric artifacts from shovel tests and a few selected prehistoric surface items were collected. All historic artifacts discovered in shovel tests 
were recorded, but only selected historic artifacts from shovel tests and from the surface were collected. All collected artifacts are housed at the University of Texas at Austin, Texas Archeological Research Laboratory (TARL).

\section{Project Background}

The AGTX Environmental Resources Management Office is charged with oversight of archaeological compliance for Camp Swift. This testing project was undertaken to meet requirements under Sections 106 and 110 of the National Historic Preservation Act (NHPA). The National Register of Historic Places (NRHP) and the Advisory Council for Historic Preservation (ACHP) were created by the NHPA. Under Sections 106 and 110 of the NHPA, the protection of cultural resources is related to their eligibility for inclusion in the NRHP, which is in turn dependent on their NRHP significance as defined in 36 CFR Part 60. The NHPA Amendments of 1992 clarified Section 110 and directed federal agencies to establish preservation programs corresponding to their activities and effects on historic properties. Under Section 110, federal agencies may evaluate the significance of cultural resources not currently threatened to assist with the development of preservation planning. The federal regulatory process is described in detail in 36 CFR Part 800. Section 106 specifies that the ACHP must be given the opportunity to comment on those cultural resources (in this case, archaeological sites) that may be eligible for listing on the NRHP. In turn, the State Historic Preservation Officer (SHPO) at the Texas Historical Commission - Department of Antiquities Protection (THC-DAP) advises the AGTX regarding their obligations under Sections 106 and 110. In compliance with the aforementioned laws and regulations, the AGTX has developed an Installation Cultural Resource Management Plan(ICRMP) for Camp Swift. It is under the jurisdiction and guidance of the discussed laws, regulations, and the ICRMP for Camp Swift that this testing project was undertaken.

\section{Report Organization}

This report is divided into a total of seven chapters, including this introductory chapter. Overviews of the environment, geology, and soils are presented in Chapter 2, while Chapter 3 synthesizes the cultural chronology and previous archaeological research in the region. Chapter 4 includes our research design for this project. It encompasses our approach to both prehistoric and historic assets, field and laboratory methodologies employed during the project, and addresses the cultural contexts and issues for the prehistoric and historic sites tested. Chapter 5 provides a site-bysite description, a description of isolated finds, and the levels and results of work conducted, followed by the conclusions and recommendations for each site individually. Chapter 6 discusses what we have learned based upon our research design and methods. Finally, a project summary and overall recommendations are presented in Chapter 7.

Appendix A presents the shovel test depths. A combined USGS Quadrangle map showing the site locations is included in a pocket envelope at the end of this report. In addition to these project and site data sets, Texas archaeological site forms were completed for all 11 sites recorded in the project area. These are available at TARL in Austin. 


\section{Chapter 2}

\section{Project Area Description}

\section{David L. Nickels and Antonio E. Padilla}

\section{Introduction}

Camp Swift is located in north-central Bastrop County, approximately eight miles north of the city of Bastrop and eight miles south of the city of Elgin. Bastrop County is approximately 30 kilometers $(\mathrm{km})$ east of the Balcones Escarpment. It is dominated by oak-hickory forests, with the relict, Lost Pine Forest in its central section, and its northwestern boundary at the edge of the Blackland Prairie (Figure 2-1). The topography is described as rolling interfluves and hills, with broad alluvial terraces along the Colorado River valley, which runs from northwest to southeast through the center of the county. Elevations within the county range from 400 feet to 600 feet above mean sea level. The 891 square-mile county is comprised of approximately one-fourth farmland, of which about one-third is used for cattle grazing, and a little over one-third is forested (Baker 1979; Bastrop County 2003).

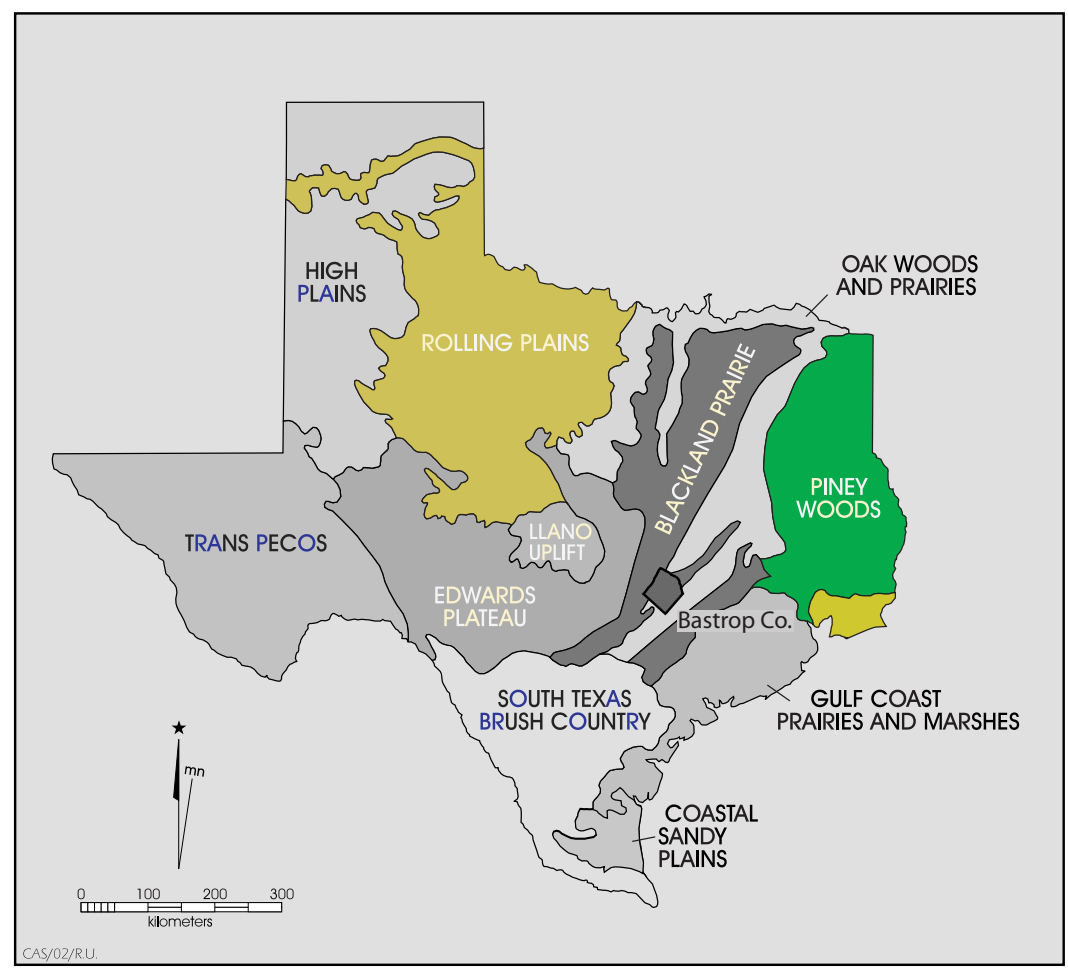

Figure 2-1. Bastrop County is situated approximately $30 \mathrm{~km}$ east of the Balcones Escarpment, on the upper Gulf Coastal plain.
Approximately 11,200 acres had previously been surveyed with varying degrees of intensity. The remaining 307 acres of land is the focus of this report (Figure 2-2). The project area lies in the northernmost portion of Camp Swift and includes the floodplains of Big Sandy Creek and two unnamed intermittent streams (Figure 2-3).

\section{Setting}

Camp Swift consists of rolling uplands, ridges, their associated slopes, and bottomlands dissected by both steadily flowing and intermit- 


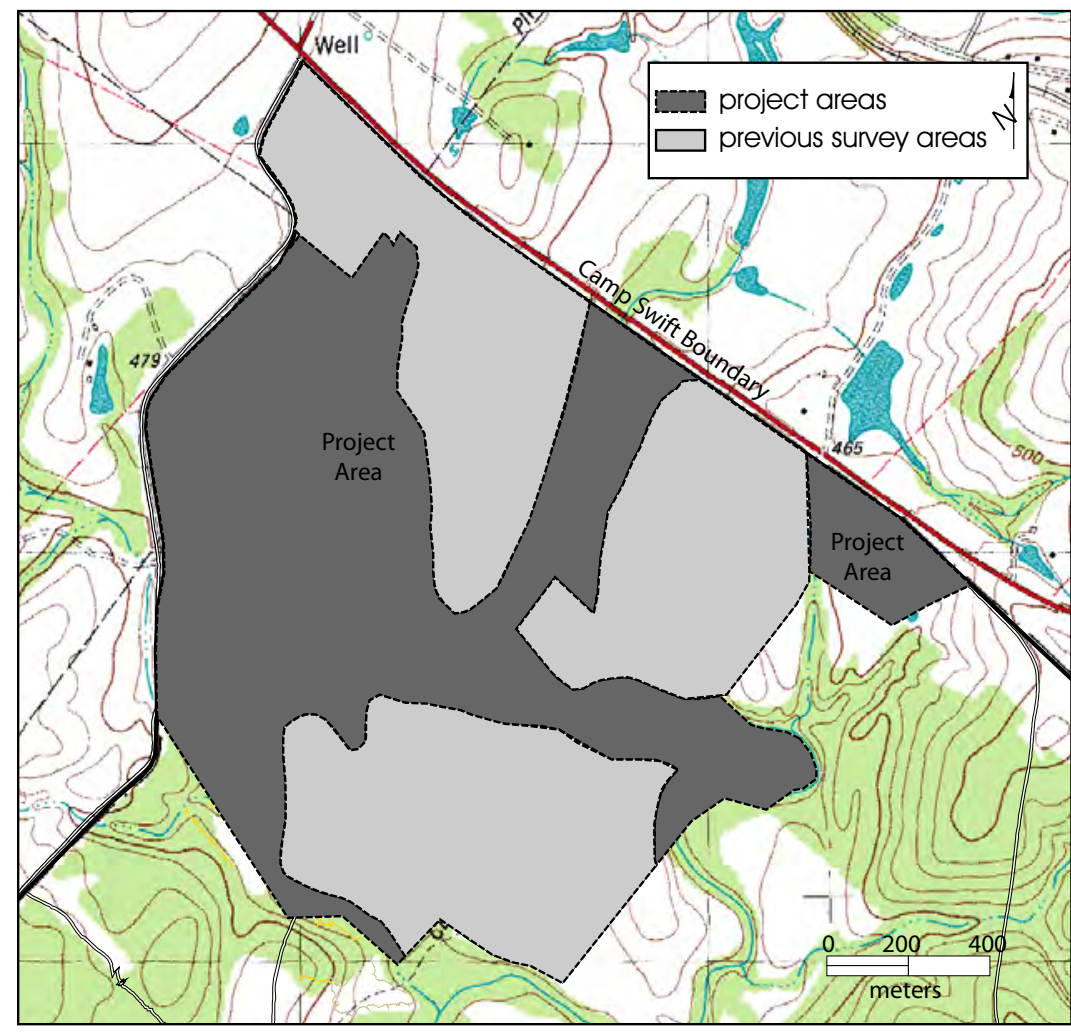

Figure 2-2.307-acre project area.

tent streams, all of which were encountered while conducting this survey. Many streams are incised and crisscross throughout the Camp. Spring Branch is the only one that is constantly flowing; Big Sandy Creek flows in some areas, and pools in many others before its waters disappear into areas of sand strata. The headwaters of Big Sandy Creek originate in western Lee County and flow through the project area in the northeastern portion of Camp Swift, eventually discharging into the Colorado River approximately $13 \mathrm{~km}$ to the southwest (Prochnow 2001; Big Sandy Creek 2003). Other intermittent streams (such as McLaughlin Creek, Dogwood Branch, and Dogwood Creek) discharge rapid runoffs during heavy rainfall (Figure 2-3).

\section{Climate}

Bastrop County has a subtropical humid climate, with cool winters and hot summers. The coolestmonth is January, with a mean temperature of $40^{\circ} \mathrm{F}$, and the warmest is July, with a mean maximum of $96^{\circ} \mathrm{F}$. The annual mean precipitation is 36.8 inches. All these factors combined allow for an annual growing season of 206 days (Bastrop County 2003).

\section{Physiography}

Camp Swift is composed of six physiographic zones; active floodplains, terraces, uplands, ridges, and foot and side slopes. Floodplains are low-lying and easily flooded during less severe, but above normal runoffs. They occur in large meanders, as over-bank sediment deposits flanking low water channels. Floodplain deposits on Camp Swift have been described by Prochnow (2001:35) as massive channel margin sands, with wavy, sandy clay lamellae representing flood episodes.

Also occurring along low water channels are terraces; although created by floodwater sedimentation, they are now further away and above active, aggrading floodplains. According to Prochnow (2001:31), terraces generally occur 3 to $5 \mathrm{~m}$ above modern stream channel beds, in modern meander belts and outer valley margins.

Above the alluvial terraces are uplands, ridges, and associated side slopes. These higher land forms, consisting of sandy loam sediments separate major drainages. The formation processes of these sandy loams are debatable, as either depositional or 


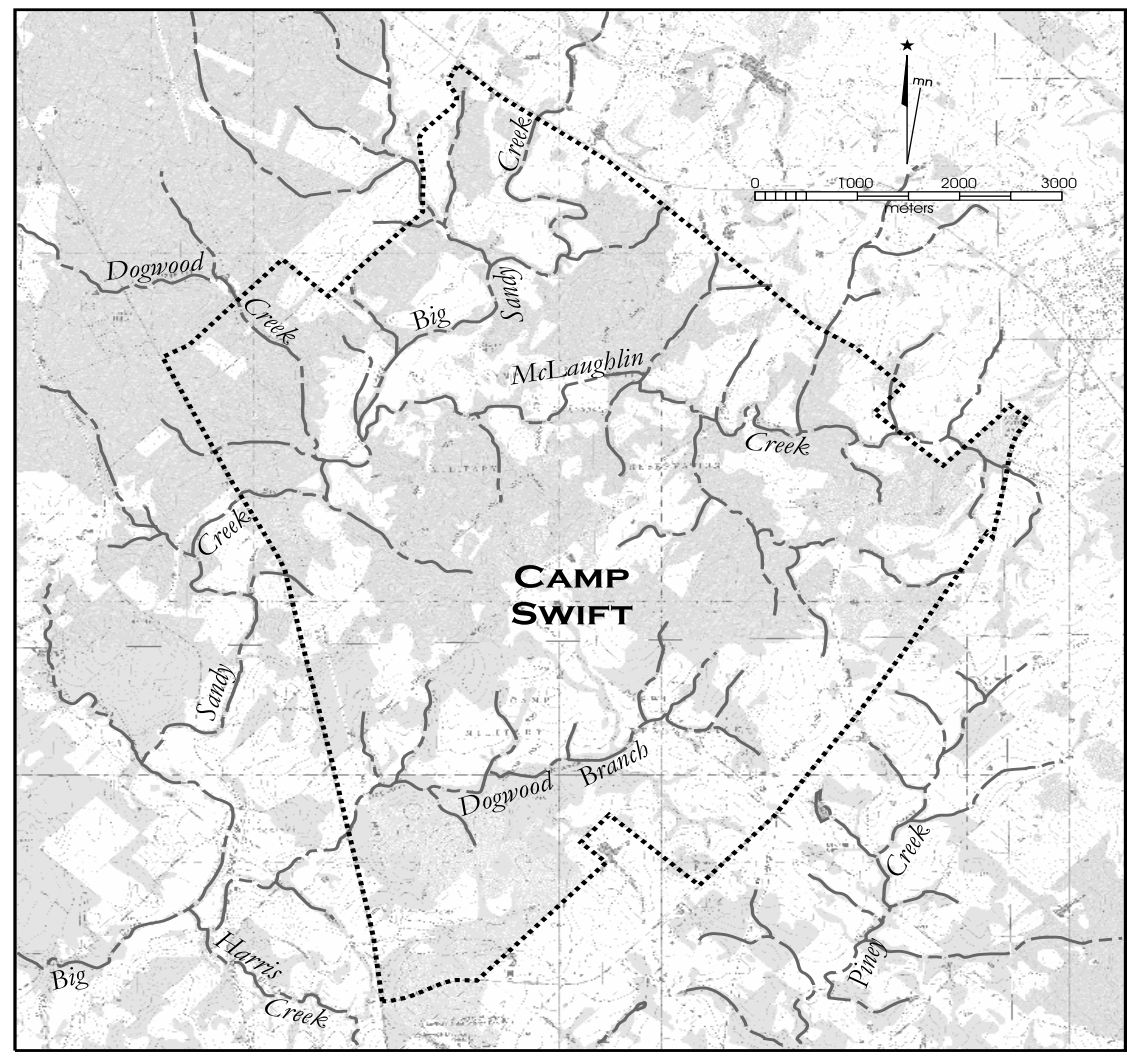

Figure 2-3. Drainages on Camp Swift.

pedogenic (see for example, Bruseth and Martin 2001; Frederick and Bateman 2001). Generally, the fine sands are underlain by clay $(\mathrm{Bt})$ horizons (Prochnow 2001).

\section{Geology and Soils}

Camp Swift's geological stratigraphy is composed of more recent sediments and soils that overlay sandstone, and light gray to yellowishbrown mudstone beds with various lignite and ironstone inclusions (Barnes 1974). These beds form the Wilcox Group. The Wilcox Group is subdivided into three formations: 1) Calvert Bluff Formation, 2) Simsboro Formation, and 3) Hooper Formation. Camp Swift is located on the Calvert Bluff Formation of the Wilcox Group (Barnes 1974). These beds weather into red buff-colored sands, confining dense lignite beds up to nine feet thick (Sellards et al. 1932:530, 584-586; Wilmarth 1938: 321). According to Judson and Kauffman (1990) the Calvert Bluff formation formed between approximately 37 and 58 million years ago. The mudstone and sandstone beds are found throughout Camp Swift. Mudstone beds are found on slopes and in valleys, and sandstone bed caps are commonly found in the uplands. Sandstone is less likely to erode, thus producing more narrow and steep valleys, while erosion of mudstone, a more friable sediment, forms broader and less steep valleys. The Big Sandy Creek valley is a good example of this process. As Big Sandy Creek enters the northeastern portion of Camp Swift, it is constricted to a width of approximately $396 \mathrm{~m}$, and as it cuts through the mudstone before exiting the northwestern portion of the Camp, it broadens to about $853 \mathrm{~m}$ (Prochnow 2001:31).

Soils most prominent at Camp Swift are classified as entisols or mollisols on floodplains and terraces, and alfisols in the uplands and slopes (Baker 1979). Entisols form in temperate regions "in coarse-textured resistant mineral parent materials (e.g., quartzite sands) that are subjected to little pedogenic development over time, ... and are commonly found on geomorphic surfaces which are unstable because of frequent flooding, erosion/ truncation, or human impact (drastically disturbed 
lands)." "They are common along floodplains, ... sand dunes in desert regions, ... and associated with recently mined or disturbed lands" (Wilding 2000:E-180). In both boreal and temperate regions, usually beneath prairie grass in North America, mollisols are found (Wilding 2000:E-181-182). "Alfisols ... are differentiated from other (soil) orders on the basis of textural differentiation resulting from translocation and/or in situ neoformation of clays that form argillic and kandic horizons." (Wilding 2000:E-182). The soil types commonly found at Camp Swift are shown in Table 2-1 (Prochnow 2001; Baker 1979).

\section{Flora}

Camp Swift is located within the vegetation region of Texas known as the Post Oak Savannah (or the Oak Woods and Prairies) (Gould 1975). This region stretches from northeast Texas, and southwesterly adjacent to the Blackland Prairie, along the base of the Balcones Escarpment (Figure 2-4). While conducting an environmental study of Camp Swift in anticipation of a portion of it being leased for lignite mining, Tera Corporation identified common vegetation within plant communities presented in Table 2-2. While conducting this investigation, archaeologists from CAS encountered many American Beauty berries (Callicarpa americana) with developed dark red berries within

Table 2-1. Soils most prominent on Camp Swift.

\begin{tabular}{|l|l|l|}
\hline Soils & Settings & Surface Textures \\
\hline Axtell series & Stream terraces and uplands & Fine sandy loam \\
\hline Demona series & Ridgetops, sideslopes, upland drainageways & Loamy fine sand \\
\hline Patilo series & Uplands & Fine sand \\
\hline Siltsid series & Uplands & Loamy fine sand \\
\hline Tabor series & Broad uplands & Fine sandy loam \\
\hline Gowen series & Floodplains, Bottomlands & Clay loam \\
\hline
\end{tabular}

Table 2-2. Common vegetation within various plant communities on Camp Swift (Tera 1978; adapted from Skelton and Freeman 1979).

\begin{tabular}{|l|l|l|}
\hline Plant Community & Vegetation & Settings \\
\hline $\begin{array}{l}\text { Post Oak-Red Cedar } \\
\text { Woodlands }\end{array}$ & Post oaks, red cedar & $\begin{array}{l}\text { Upper valley margins, } \\
\text { upland divides, sandy soils }\end{array}$ \\
\hline Mesquite Brushland & $\begin{array}{l}\text { Mesquite, red cedar, netleaf } \\
\text { hackberry, winged elm }\end{array}$ & $\begin{array}{l}\text { Disturbed slopes and knolls, } \\
\text { soils eroded to clay }\end{array}$ \\
\hline Old Field & Grasses, weeds & $\begin{array}{l}\text { Floodplains, lower valley } \\
\text { margins, thick sand }\end{array}$ \\
\hline Riparian & $\begin{array}{l}\text { Red cedar, black willow, } \\
\text { elm, cottonwood, black } \\
\text { hickory, pecan, pot oak, } \\
\text { hackberry }\end{array}$ & Floodplains \\
\hline
\end{tabular}




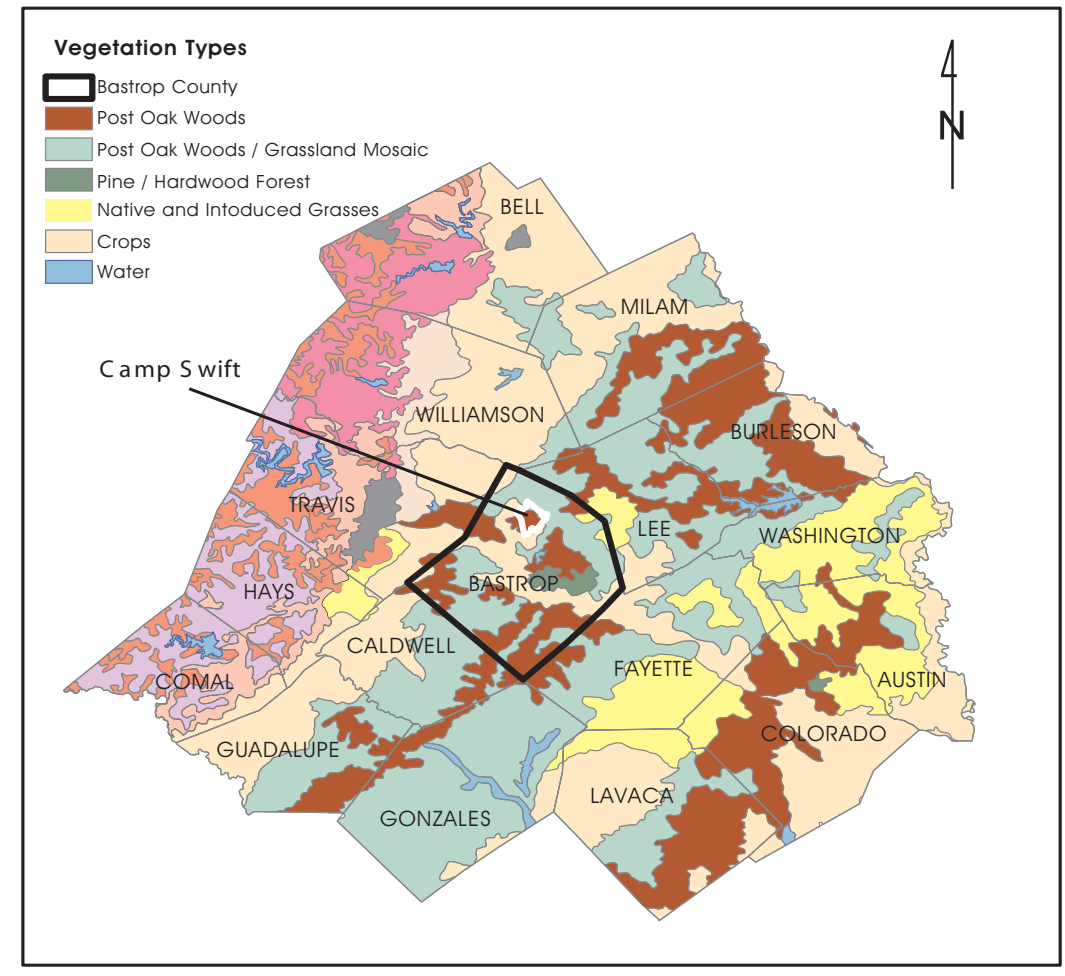

Figure 2-4. Camp Swift is located within the Post Oak Savannah vegetation region.

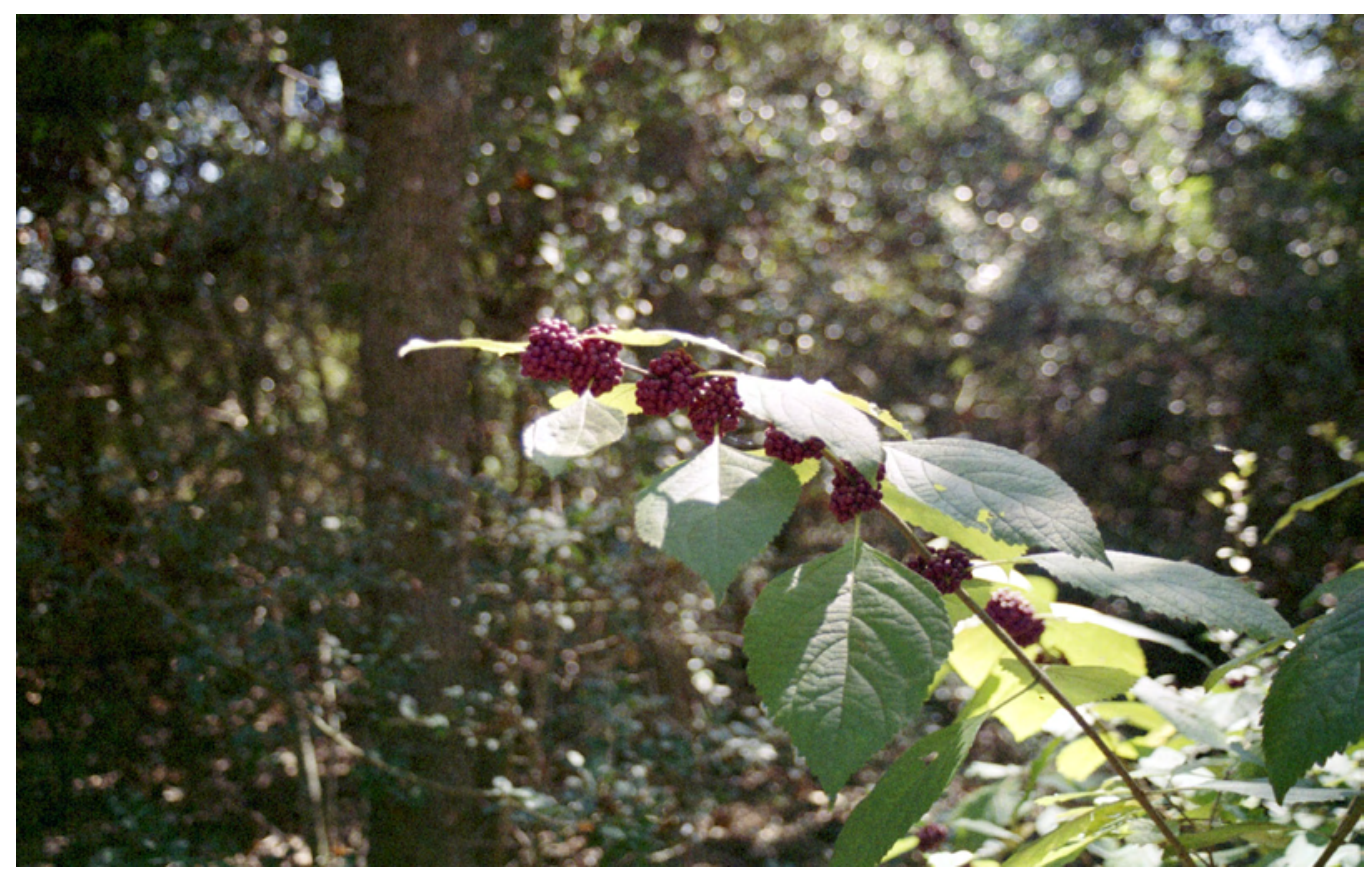

Figure 2-5. American Beautyberry (Callicarpa americana) with developed dark red berries, grow within the well-drained, wooded areas in the uplands of creeks or tributaries. 


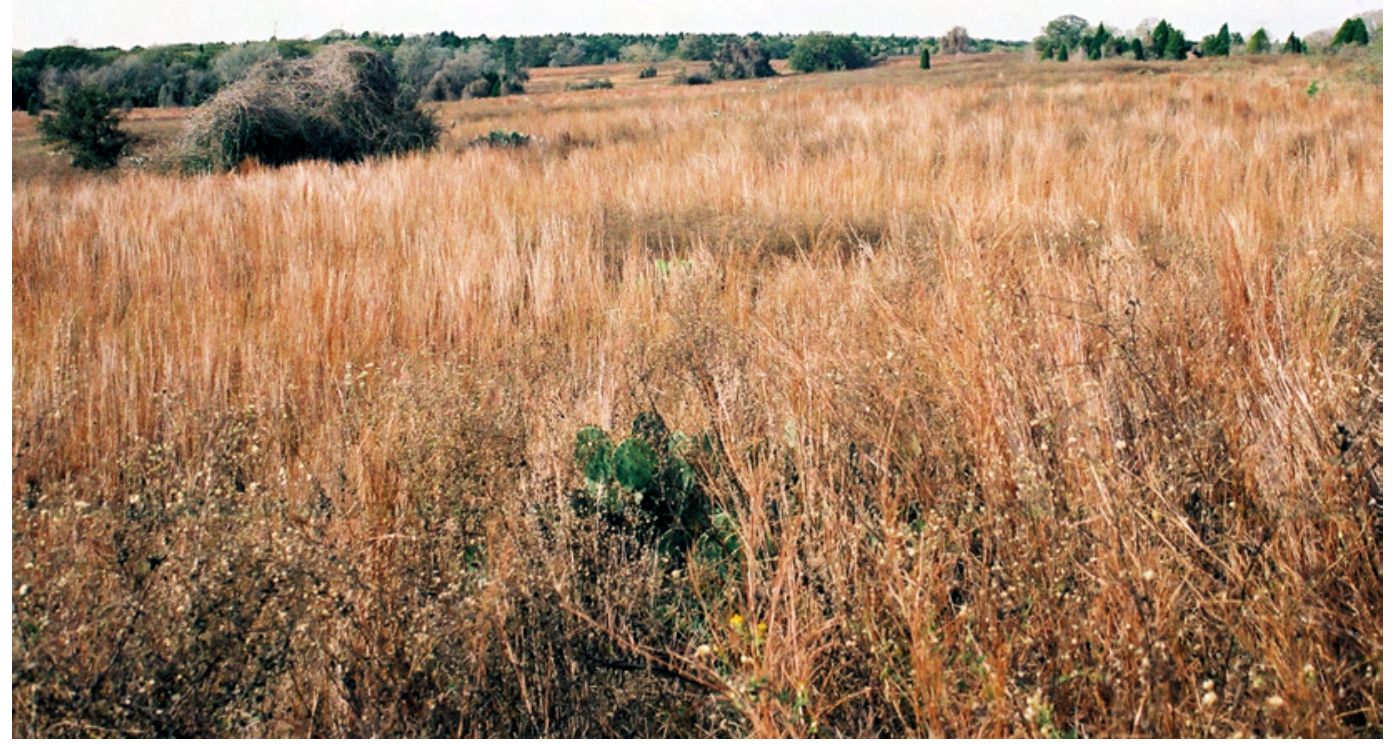

Figure 2-6. Heavily wooded stream courses and grass-covered, rolling uplands are typical of the terrain and vegetation at Camp Swift.

the well-drained, wooded areas in the uplands of creeks or tributaries (Figure 2-5 and 2-6).

\section{Fauna}

Camp Swift lies within the Texan biotic province (Figure 2-7) defined by Blair (1950). Along with the wide variety of flora that exists within the 11,500 acres of Camp Swift, a very diverse animal population also inhabits the area. Tables 2-3 through 2-5 show those animals likely to migrate through or make the Camp their permanent habitat (Tera 1978; Nightengale and Moncure 1996).

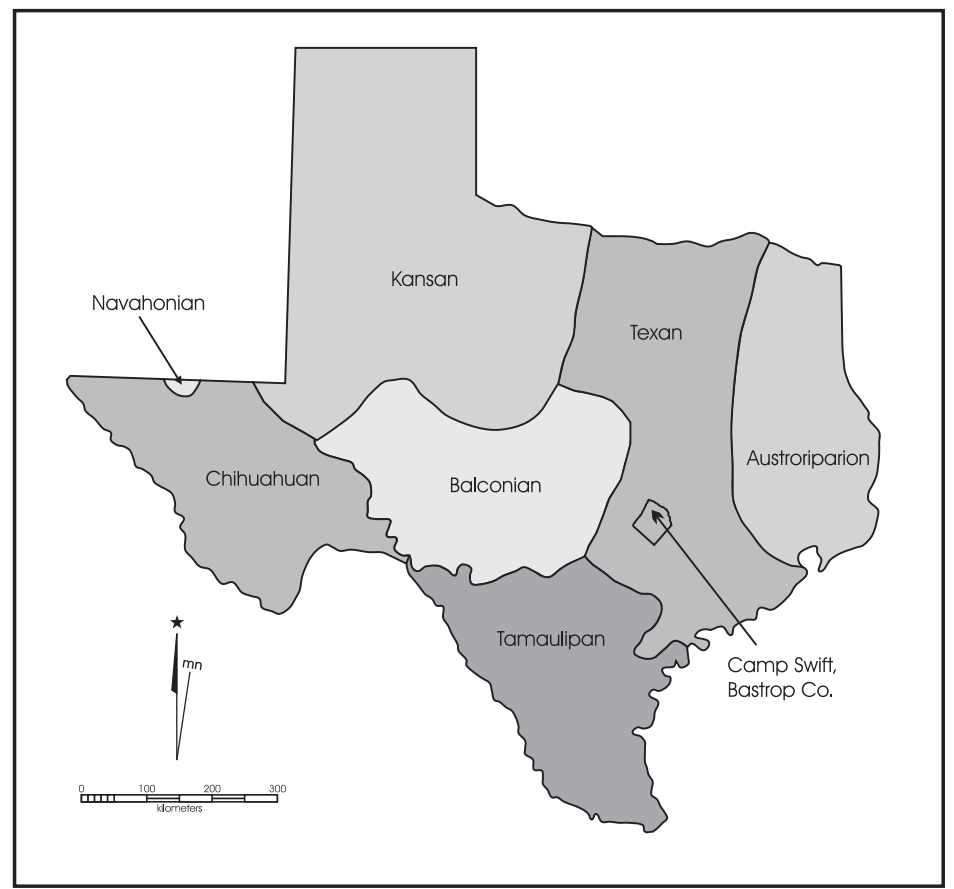

Figure 2-7. Camp Swift lies within the Texan biotic province. 
Table 2-3. Mammals expected to either visit or inhabit the project area.

\begin{tabular}{|c|c|c|c|}
\hline Common Name & Scientific Name & Common Name & Scientific Name \\
\hline white tailed deer & $\begin{array}{l}\text { Odocoileus } \\
\text { virginianus }\end{array}$ & black tailed jackrabbit & Lepus californicus \\
\hline coyote & Canis latrans & striped skunk & Mephitis mephitis \\
\hline grey fox & $\begin{array}{l}\text { Urocyon } \\
\text { cinereoargenteus }\end{array}$ & eastern cottontail & Sylvilagus floridanus \\
\hline bobcat & Lynx rufus & plains pocket gopher & Geomus bursarius \\
\hline raccoon & Procyon lotor & $\begin{array}{l}\text { spotted ground } \\
\text { squirrel }\end{array}$ & $\begin{array}{l}\text { Spermophilus } \\
\text { spilosoma }\end{array}$ \\
\hline opossum & $\begin{array}{l}\text { Didelphis } \\
\text { virginiana }\end{array}$ & piñon mouse & Peromyscus truei \\
\hline grey squirrel & Sciurus carolinensis & $\begin{array}{l}\text { nine-banded } \\
\text { armadillo }\end{array}$ & $\begin{array}{l}\text { Dasypus } \\
\text { novemcinctus }\end{array}$ \\
\hline wild hog & Sus scrofa & cougar & Felis concolor \\
\hline hispid cottonrat & Sigmodon hispidus & $\begin{array}{l}\text { fulvous harvest } \\
\text { mouse }\end{array}$ & $\begin{array}{l}\text { Reithrodontomys } \\
\text { fulvescens }\end{array}$ \\
\hline white-footed mouse & $\begin{array}{l}\text { Peromyscus } \\
\text { leucopus }\end{array}$ & & \\
\hline
\end{tabular}

Table 2-4. Reptiles expected to either visit or inhabit the project area.

\begin{tabular}{|l|l||l|l|}
\hline Common Name & Scientific Name & Common Name & Scientific Name \\
\hline $\begin{array}{l}\text { western diamondback } \\
\text { rattlesnake }\end{array}$ & Crotalus atrox & $\begin{array}{l}\text { broad-banded } \\
\text { copperhead }\end{array}$ & $\begin{array}{l}\text { Agkistrodon } \\
\text { contortrixnlaticinctus }\end{array}$ \\
\hline checkered garter snake & $\begin{array}{l}\text { Thamnophis } \\
\text { marcianus } \\
\text { marcianus }\end{array}$ & great plains skink & Eumeces obsoletus \\
\cline { 1 - 2 } yellow mud turtle & $\begin{array}{l}\text { Kinosternon } \\
\text { flavescens }\end{array}$ & western cottonmouth & $\begin{array}{l}\text { Agkistrodon } \\
\text { piscivorus leucostoma }\end{array}$ \\
\hline $\begin{array}{l}\text { eastern yellow belly } \\
\text { racer (blue racer) }\end{array}$ & $\begin{array}{l}\text { Coluber constricter } \\
\text { flaviventris }\end{array}$ & ornate box turtle & Terrapene ornate \\
\hline $\begin{array}{l}\text { common snapping } \\
\text { turtle }\end{array}$ & $\begin{array}{l}\text { Chelydra } \\
\text { serpentina }\end{array}$ & red eared slider & $\begin{array}{l}\text { Trachemys scritpta } \\
\text { elegans }\end{array}$ \\
\hline
\end{tabular}

Table 2-5. Birds expected to either visit or inhabit the project area.

\begin{tabular}{|l|l||l|l|}
\hline Common Name & Scientific Name & Common Name & Scientific Name \\
\cline { 2 - 2 } scissor-tailed flycatcher & Muscivora forficata & red tailed hawk & Buteo jamaicensis \\
\cline { 2 - 2 } red-bellied woodpecker & Centurus carolinus & western meadowlark & Sturnella neglecta \\
\hline Carolina chickadee & Parus carolinensus & American robin & Turdus migratorius \\
\cline { 2 - 3 } brown thrasher & Toxostoma rufum & northern mockingbird & Mimus polyglottos \\
\hline painted bunting & Passerina ciris & lark sparrow & $\begin{array}{l}\text { Chondestes } \\
\text { grammacus }\end{array}$ \\
\hline turkey vulture & Cathartes aura & mourning dove & Zenaidura macroura \\
\hline northern bobwhite & Colinus virginianus & greater roadrunner & $\begin{array}{l}\text { Geococcyx } \\
\text { californianus }\end{array}$ \\
\hline northern cardinal & $\begin{array}{l}\text { Cardinalis } \\
\text { cardinalis }\end{array}$ & & \\
& & & \\
\hline
\end{tabular}




\title{
Chapter 3
}

\section{Previous Archaeological excavations}

\author{
David L. Nickels and James E. Barrera
}

\section{Cultural Chronology}

Because of their locations, Camp Swift and Bastrop County lie in a transitional zone, with cultural influences from the Central, East, and Upper Coastal Regions of Texas (Goode 1989). Using the earlier works of Suhm (1957), Johnson et al. (1962) and Sorrow et al. (1967) as a springboard, Weir(1976) and Prewitt $(1981,1985)$ sorted through the archaeological data from Central Texas and established a chronology defined by phases. Collins (1995) reviewed the archaeological and palynological evidence for Central Texas and offered new chronological estimates for human occupation from the Paleoindian through Historic periods. Johnson and Goode (1994) accomplished the same for the Eastern Edwards Plateau. Patterson (1995) has synthesized the chronological evidence for Southeast Texas, including the Upper Coastal Region (see Figure 3-1). All dates given in the following discussion are approximate and given as years before present (B.P.), i.e, before A.D. 1950 when radiocarbon analysis was established.

\section{Paleoindian}

This period spans the time between ca. 11,5008400 B.P. in Central Texas (Collins 1995:381383), 12,000-7,000 B. P. in Southeast Texas (Patterson 1995), and between 11,500-7950 in the Pineywoods of northeast Texas (Perttula 1995). The Paleoindian period is divided into Early and Late intervals. The Early Paleoindian interval began toward the close of the Pleistocene. Diagnostic artifacts of the early Paleoindian interval include Clovis and Folsom projectile points. While Angostura, Wilson, Golondrina, St. Mary's Hall, and Barber (among others) appear during the Late Paleoindian interval (Bousman et al 2004).

Certainly, the distribution of Clovis-type points across most of North America and even into Central America suggests a wide dispersal and interaction of the people who made them (Kelly 1993; Wenke 1990:201). Within Texas' political boundaries, Meltzer and Bever (1995:47-81) have documented the presence of 406 Clovis points in 128 of 254 counties. In Southeast Texas, Patterson (1995:252) notes that "There are considerable data to indicate that San Patrice and Early Side-Notched were the principal point types in Southeast Texas during the Early Paleoindian period."

In general, the Early Paleoindian adaptation has been considered to be one of small bands of nomadic, big-game hunters following herds of Late Pleistocene fauna, including mammoth, mastodons, bison, camel, and horse, across North America (Black 1989a). More recently, emphasis has been placed on the wide diversity of animals and possibly plants used for subsistence by these early Americans (Black 1989b; Bousman et al 2004), such as turtles and tortoises, alligators, mice, badgers, and 
Table 3-1. Cultural chronologies pertinent to the Camp Swift area.

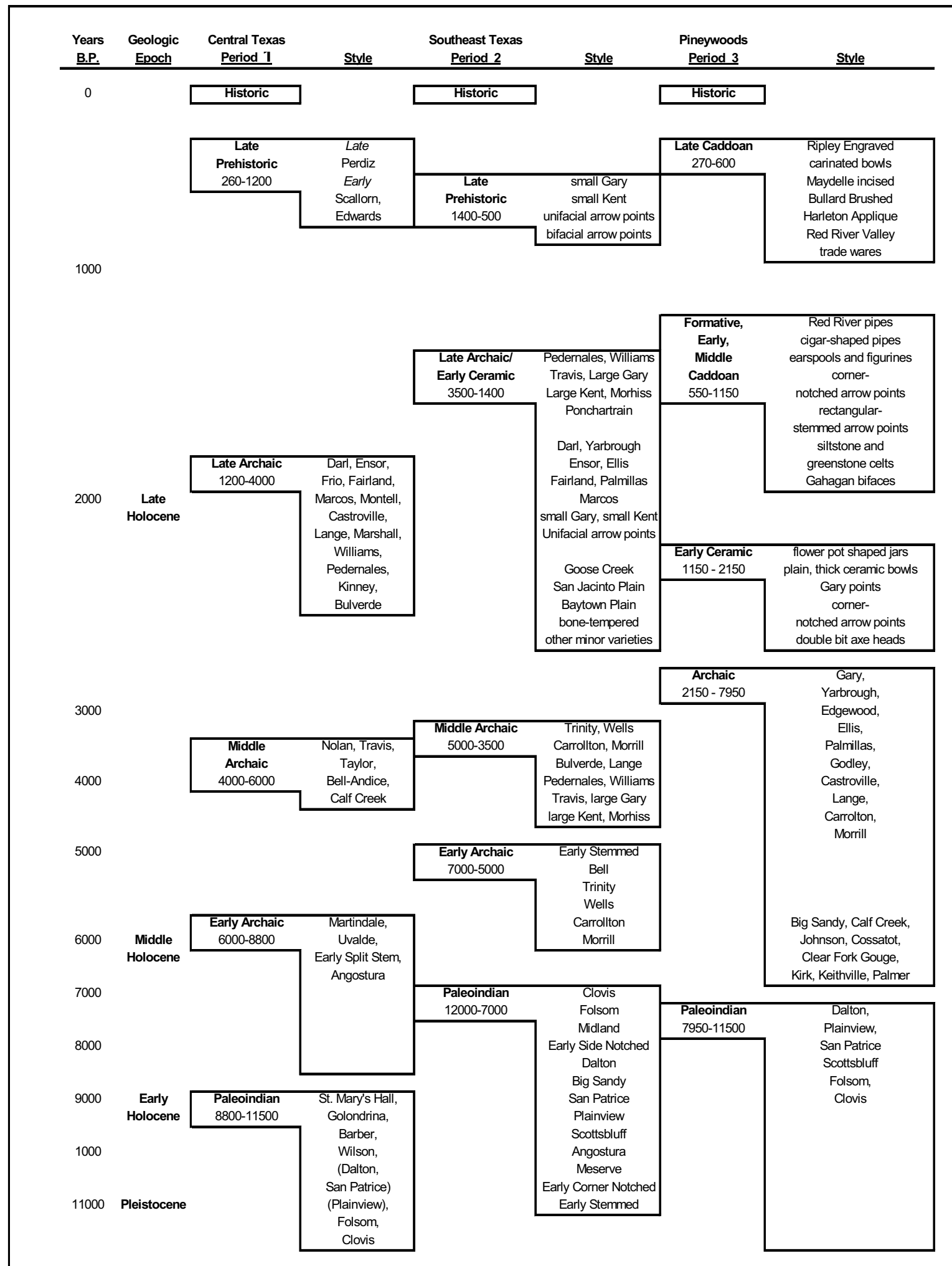

1. Collins 1995; 2. Patterson 1995; 3. Perttula 1995 
raccoons (Collins 1995:381; Collins and Brown 2000), although they undoubtedly hunted the large animals as well (Bousman et al 2004). Known Clovis sites include kill-sites, quarries, caches, open campsites, ritual sites, and burials (Collins 1995:381$383)$.

The Folsom interval follows the Clovis. Folsom artifacts are fairly common in Central Texas (Bousman et al. 2004), and these groups are often portrayed to be specialized bison hunters (Dibble and Lorrain 1968).

Most Paleoindian finds in Central Texas have consisted of surface lithic scatters on upland terraces and ridges and lack economic data (Black 1989a:25, 1989c:48). A few deeply buried Paleoindian components have been discovered in alluvium, such as Berclair Terrace in Bell County (Sellards 1940), Berger Bluff in Goliad County (Brown 1987), Kincaid Rockshelter in Uvalde County (Collins et al. 1989), Wilson-Leonard in Williamson County (Bousman et al. 2002; Collins et al. 1993; Collins et al. 1998), and the Gault site in Williamson County (Collins and Brown 2000).

As the warming trend that marked the transition from Pleistocene to Holocene climates began to take effect in Texas, prehistoric inhabitants adapted with changes in lifestyle. This climatic shift is also marked by the decline and extinction of mammoth, mastodon, horse, and camel. Giant bison (Bison antiquus) continued for a few thousand more years when it evolved into modern bison.

Archaeological evidence suggests that after 10,000 B.P., most large game animals were extinct in Texas (Bousman et al 2004). Human hunters were forced to concentrate on deer, antelope, and other medium-size or smaller game. Changes in the subsistence base required technological shifts that mark the beginning of the Late Paleoindian interval. The period between 10,000 B.P. and 8000 B.P. reflects a period of adjustment and transformation in Central Texas (Bousman et al 2002). Evidence of plant food procurement is first present in Central Texas in this interval and in the Lower Pecos evidence of extremely broad diets is present (Bousman et al. 2004). The Late Paleoindian interval is also the period when more widespread evidence of burial customs is evident (Bousman et al. 2004). However, by 8000 B.P. the period of experimentation had developed into a well recognized pattern known as the Archaic.

\section{Early Archaic}

As defined here, Collins (1995:383) dates the Early Archaic from 8400 to 6000 B.P. in Central Texas, although Bousman et al (2004) suggest it began at 8000 B.P. Patterson (1995) posits that the period covers approximately 2,000 years, from 7000 to 5000 B.P. in Southeast Texas. In East Texas, the Archaic interval begins around 7950 B.P (Perttula 1995). In general, more intensive exploitation of local and smaller resources in Central Texas - such as deer, fish, rodents, and plant bulbs - is indicated by greater densities of ground stone artifacts, fire-cracked rock cooking features, and more specialized tools such as Clear Fork gouges and Guadalupe bifaces (Collins 1998; Turner and Hester 1999:246, 256). Weir(1976) speculates that Early Archaic groups were small and highly mobile, an inference based on the fact that Early Archaic sites are thinly distributed and that diagnostic projectile point types are seen across a wide area, including most of Texas and Northern Mexico.

Story (1985) believes that population densities were low during the Early Archaic, and that groups consisted of related individuals in small bands with "few constraints on their mobility." (Story 1985:39) Their economy was based on the utilization of a 
wide range of resources, especially such yearround resources as prickly pear and lechugilla, as well as rodents, rabbits, and deer (Story 1985:38).

\section{Middle Archaic}

Collins (1995:383) defines this intermediate interval of the Archaic as lasting from about 6000 4000 B.P. in Central Texas. Patterson (1995) believes the 1,500 years between 5000 and 3500 B.P. represent this period in Southeast Texas. The Middle Archaic perhaps continued until around 3000 B.P. in Northeast Texas although the evidence is poorly dated (Perttula 1995; Story 1990). Based on the large number of sites from this period in Central Texas, the Middle Archaic appears to have been a time of increased population (Story 1985:40; Weir 1976:125, 128). However, further to the east of the Balcones Escarpment, near Camp Swift, Middle Archaic sites are very rare and this probably represents a regional population decline. This phenomena is not unusual in certain regions of Texas. For example the Middle Archaic period in the High Plains is viewed as occurring earlier (Johnson and Holliday 1986:46), it was all but abandoned during the 3,000-year dry and warm Altithermal (Hughes 1991).

Weir $(1976: 125-126,128)$ suggests that as the climate became moister, deer and acorns thrived in Central Texas, attracting groups at least seasonally, from all other regions of Texas. Other archaeologists (e.g., Story 1985:40; McKinney 1981) have argued that during the dry Middle Archaic, Native Americans basically deserted drier regions of Texas and congregated in Central Texas where numerous springs were still flowing, and subsistance resources were more abundant. Bousman (1998) interprets the pollen evidence from Boriack Bog as reflecting a long severe drought in the Middle Holocene.
A wide variation in projectile point styles suggests an increased diversity of Native American groups concentrated along the Balcones Escarpment. These groups were hunting a wide variety of animals and exploiting a diverse set of plants, especially seasonally available nuts (Black 1989b; Hall 1998). Weir (1976) believes that the widely scattered bands prevalent in the Early Archaic now began to coalesce, at least during the acorn-gathering season, into larger groups who shared the intensive work of gathering and processing the acorn harvest (Weir 1976:126). Many researchers, (Creel 1986; Prewitt 1991; Weir 1976), believe burned rock middens are a result of this endeavor, but other investigators such as Black et al. (1997) and Goode (1991) doubt this conclusion. Regardless, the exact processes which formed these middens are still a matter of controversy (Black 1989a:28; Black et al. 1997; Leach and Bousman 2001; Leach et al. 2005; Mauldin 2003a).

The common presence of deer remains in burned rock middens encourages the view that deer processing took place at these sites (Nickels et al. 2001; Black and McGraw 1985:278; Weir 1976:125). Bison bone is encountered in archaeological sites in Central Texas, at least occasionally, during all but the earliest part of the Middle Archaic (Dillehay 1974). There has been a tendency to equate the presence of burned rock middens with the absence of bison (Prewitt 1981); however, examinations of several recent faunal reports show that after about 4500 B.P. bison and burned rock middens are contemporaneous, at least in the southern Edwards Plateau and northern South Texas Plains (Meissner 1993). Cemeteries make their first appearance during this period, suggesting a movement toward less mobility, and perhaps more distinct territorial boundaries. 


\section{Late Archaic}

Collins (1995:384) dates the final interval of the Archaic in Central Texas to approximately 4000 1200 B.P. The Late Archaic opens at approximately the same time period in the Pineywoods, but in Southeast Texas, it represents the Early Ceramic period, about 3500-1400 B. P. (Patterson 1995). The most common projectile points are Ensor and Frio types (Turner and Hester 1993:114,122), both of which are short, triangular points with side notches. The Frio point also has a notched base (Turner and Hester 1999:122).

Some researchers believe populations increased throughout the Late Archaic (e.g., Prewitt 1985; Skinner 1981), while others feel populations remained the same or decreased during this period (Black 1989a:30). Prewitt (1981:80-81) asserts that the accumulation of burned rock middens nearly ceased during the course of this period; however, recent excavations provide evidence that large cooking features up to $15 \mathrm{~m}$ in diameter were still in use, and indeed became more prolific in the following Late Prehistoric period (see Black et al. 1997; Mauldin and Nickels 2003). Subsistence is assumed to have become less specialized on acorns in favor of a broad spectrum subsistence base (Black 1989a:30). By 1450 B.P., bison had again disappeared (Dillehay 1974). Story (1985:44-45) believes the presence of cemeteries at sites such as Ernest Witte in Austin County (Hall 1981), Hitzfelder Cave in Bexar County (Givens 1968), and Olmos Dam, also in Bexar County (Lukowski 1988) indicates that Late Archaic populations in Central Texas were increasing, and the indigenous groups were becoming more territorial in the Middle Archaic.

\section{LatePrehistoric}

The term "Late Prehistoric" is commonly used to designate the period following the Late Archaic, and is generally thought of as spanning the period 1200-420 B.P. in Central Texas (Collins 1995). Two distinct phases recognized within the Late Prehistoric in Central Texas are the Austin and Toyah phases. Collins (1995:385) recognizes that the commonly used date of 1200 B.P. for the end of the Archaic, and the beginning of the Late Prehistoric in Central Texas is arbitrary. A series of distinctive traits marks the shift from the Archaic to the Late Prehistoric period, including the technological shift to the bow and arrow and the introduction of pottery to Central Texas (Black 1989a:32; Story 1985:45-47). Most researchers agree the Austin phase was a time of population decrease in Central Texas (e.g., Black 1989a:32; Collins 2004; Dillehay 1974; Prewitt 1981, 1988).

Patterson (1995) agrees with Hudson (1976) that dart points such as Gary, Kent, Ellis, and Ensor were still being used in the inland areas of Southeast Texas during the Late Prehistoric period, 1400-500 B.P. He further suggests that the bow and arrow were used into Southeast Texas toward the end of the Middle Archaic, ca. 3500 B.P. Although the only evidence is small unifacially flaked points. This Middle Archaic model is not widely accepted. However, bifacial arrow point technology developed about 1350 B.P. in Southeast Texas and only occured in Central Texas starting around 1200 B.P.

\section{AustinPhase}

During the Austin phase, there appears to be a subtle transition from expanding stem dart points and large, early arrow points (e.g. Edwards point) to only smaller arrow points (e.g. Scallorn). The most prevalent point found at Austin phase sites is the Scallorn arrow point. Based on radiocarbon dates from burned rock middens, it appears that many more large cooking features were constructed and used for plant processing, among other subsistence items during this period (e.g., Mauldin 
2003b). Bison are not present in the Austin phase, and deer are commonly hunted (Collins 1995).

Settlement shifts into rockshelters such as Classen Rockshelter in northern Bexar County (Fox and Fox 1967; Shafer 1977; Skinner 1981) have been noted but these shifts are poorly understood. Cemeteries from this period often reveal evidence of conflict (Black 1989a:32). For example, an excavation of a burial just north of San Antonio (41BX952) revealed an Edwards point between two lumbar vertebra (Meissner 1991), and six human skeletons were exhumed from the Loeve-Fox site in Williamson County “.... with arrow points (all of the Scallorn type) in such a manner as to suggest that the penetration of projectiles was the cause of death" (Prewitt 1974:46).

\section{ToyahPhase}

Beginning rather abruptly at about 650 B.P. in Central Texas, a shift in technology occurred. This phase is characterized by the introduction of blade technology, the first ceramics in Central Texas (bone-tempered plain wares), a narrow contracting stem point type called Perdiz, and alternately beveled bifaces (Black 1989a:32; Huebner 1991:346). The Perdiz arrow point may best represent the appearance of a distinct culture in south Central Texas lasting for about 300 years, which archaeologists have labeled the Toyah phase.

In the late 1940s, J. C. Kelley (1947a; 1947b) identified the Perdiz arrow point with what he termed the Toyah Focus. Six years later, Jelks (1953) demonstrated that Scallorn (Austin Focus) projectile points were found underlying Perdiz and Cliffton (Toyah Focus) arrow points in the Blum Rockshelter. A few years after that, Suhm (1957) confirmed the predominance of Perdiz and Cliffton points as characteristic of the Toyah assemblage, vertically positioned over Austin Foci Scallorn points at a number of sites including Smith Rock Shelter in
Travis County. Other apparently intrusive arrow points in Toyah assemblages include Fresno points from the North Texas area.

Based on his excavations at Kyle Rock Shelter at Lake Whitney, Jelks' (1962:86-90) Toyah traits include: Perdiz and Cliffton arrow points, doublepointed and beveled knives, gravers, small drills, stone side-scrapers, expedient scrapers, crude bifaces, bison bone scrapers, deer bone spatulates, bone awls, Leon Plain and possibly intrusive pottery, ground stone, hematite pigment, worked mussel shells, smoothed antler tines, pendants, tubular bone beads, fishhooks, and needles, along with perishable wood and grass/mat items.

$$
\text { In Jelks's (1962:99) opinion, }
$$

"The Toyah Focus probably came to an end during the Late Prehistoric period, at which time it was replaced over much or all of central Texas by a short-lived complex of artifacts that included triangular arrow points, Goliad Plain pottery (described by Monger, 1959:164-165), and probablyother distinctive artifact styles. This hypothetical complex---if it actually exists---may represent the acheological remains of the historic and protohistoric Tonkawa and/or Jumano Indians." [Jelks 1962:99].

In the late 1960s, the term "Foci" and most of the concepts introduced by McKern's Midwestern System of Classification (McKern 1939) fell into disfavor and by the 1980s Austin and Toyah were being called phases.

Prewitt (1985) and Black (1989a) suggest Toyah technology encroached from north Central Texas. However, Patterson (1988) notes the Perdiz point was first seen in Southeast Texas by about 
1350 B.P. and was introduced to the west some 600-700 years later. Conversely, Johnson (1994) suggests that the Perdiz point seems to have had its origin along the western periphery of the Edwards Plateau, and perhaps its advanced technology spread quickly. Although its style is unique, and some would argue that style is the indicator of change (e.g. Sackett 1989; Weissner 1983), Johnson and Goode (1994) argue that it was functionally designed to hunt bison. Johnson (1994) believes the piercing point would have been ideal if shot in adequate numbers to make the bison bleed to death. Perdiz points are widely found throughout Texas, and often associated with bison kills ( Ricklis and Collins 1994).

Huebner (1991) suggests that the sudden return of bison to Central Texas resulted from a more xeric climate in the plains north of Texas, and increased grasses in the Cross-Timbers and Post Oak Savannah in north Central Texas, forming a "bison corridor" into the South Texas Plain along the eastern edge of the Edwards Plateau (Huebner 1991:354-355). Sites from this period frequently have bison bone beds (Black 1986; Black and McGraw 1985; Henderson 1978; Hulbert 1985; Prewitt 1974).

Although bone-tempered pottery with stickbrushed exteriors is considered diagnostic to Toyah, intrusive wares are also present. Sometimes found are asphaltum-coated sherds, a Karankawan, Texas Gulf Coast tradition. Some of the vessels found at Toyah sites are identical in decoration to Northeast Texas Caddoan vessels. Others show a Jornada Mogollon influence, particularly ollas, while others appear very similar to the Los Angeles type found in Sierra de Tamalipas (Perttula et al. 1995). In many cases, the jars found at Toyah sites contain residue, presumably from boiling bones for grease. The faunal assemblages would seem to support this presumption, as most are severely splintered, crushed and broken. The fact that crushed bone appears in much of Toyah pottery may not be a coincidence (Hester 1995).

Archaeological evidence that domesticated plants were introduced in Central Texas include a single corncob found in Late Prehistoric context in Timmeron Rockshelter in Hays County (Harris 1985), one found during excavations in Kyle Shelter in Hill County (Jelks 1962:113-114), and Zea mays remains at the Wild Turkey Midden (41MI8) in Mills County (Holloway 1988:4,8). However, there simply is not enough evidence to postulate there was ever a significant presence of maize in the area, nor that it was grown there. However, limited maize agriculture may have been practiced in North Texas near Dallas sometime between 850650 B.P. at the Cobb-Pool site (Martin 1988), and stable isotope data suggest that Caddos relied significantly on maize by 650 B.P. (Perttula 1995:337). The arrival of the Spanish during the later Protohistoric/Historic period brought significant cultivars to Central Texas.

\section{Protohistoric/Historic}

The end of the Late Prehistoric and beginning of the Historic period in East, Northeast, Southeast, and Central Texas is characterized by written accounts of European contact with indigenous groups. The Protohistoric period begins in 1528 when Spanish explorer Cabeza de Vaca traversed parts of Southeast Texas and left a diary of his five years spent traveling among the hunter-gatherers of Texas and northern Mexico (Covey 1961). In 1541, Coronado entered the Texas Panhandle with hopes of finding riches (Winship 1896). The same year, after assuming command from Hernando de Soto, Spanish explorer Luis de Moscoso Alvarado ventured into Northeast Texas and encountered Caddoan-speaking groups before turning back 
(Swanton 1939). In 1568, Englishman David Graham traveled from Mexico to Nova Scotia inland along the Texas Gulf Coast (Cutrer 1985:7-12).

By the 1550s, the Spanish had established large ranches in Northern Mexico, using Indian slaves as labor. Large mining ventures in Northern Mexico did the same. This encroachment from the south forced Native Americans to escape into South and Central Texas. Later the Spanish pushed into New Mexico and made Santa Fe the capital in 1598. Their harsh treatment of the natives lead to the Pueblo Rebellion of 1680. Before the Pueblo Rebellion a few horses had been acquired by Southern Plains groups, but as a result of the Spanish abandonement of New Mexico thousands of horses were left behind. These animals provided greater mobility for Native Americans and the impact would disrupt the original Central Texas Native America groups forever. The Apache now owned a means of transportation that would allow them to hunt and raid throughout the region. By the mid-1700s, the Apache were taking over hunting grounds of other groups in Central Texas. By that time, the French and English were encroaching from the east, and establishing trade relations with Indians up and down the Red River (Morris 1970:80-81).

Although the establishment of Spanish missions around San Antonio and East Texas in the late 1600 s and early 1700 s resulted in neophyte conversions and Native Americas living inside the missions, it is a time when few written documents exist detailing Native American life outside the missions. As a result, the Historic period is generally thought of as beginning in the 1700s, or ca. 260 B.P. in Central Texas (Collins 1995:386-387).

This early Historic or protohistoric period is best documented by the records of Spanish priests in charge of the missions, and the various priests and soldiers sent to inspect the missions and the unpredictable frontier. During this period the Spanish government launched several expeditions into New Spain(Texas). Early Spanish entradas through Bastrop County include those of Domingo Terán de los Rios in 1691, Pedro de Aguirre in 1709, and Louis Juchereau St. Denis in 1714. And in 1804, a small Spanish fort named Puesta de Colorado was built at the Camino Real crossing on the Colorado River (Leffler 2001). However, the Spanish did not establish permanent settlements in Bastrop County.

By 1827, Mexico had gained its independence from Spain, and European settlers were moving into the Bastrop area in Stephen F. Austin's "Little Colony". As an empresario, Austin was to settle 100 families east of the Colorado River in presentday Bastrop County. However Indian presence impeded further westward settlement toward the Camp Swift area until around 1836, when Texas gained its independence from Mexico and the Texas Rangers offered better protection (Leffler 2001). Although peace was declared under a treaty with the Comanche in 1845, Indian conflicts continued to occurr (e.g., Wilbarger 1985).

\section{Previous Archaeological Investiga- tions in Bastrop County and Camp Swift}

\section{Earliest Archaeological Investigations}

A. M. Wilson conducted the first archaeological work in the Bastrop area, surveying along the central portion of the Colorado River in Travis, Bastrop, and Fayette counties. Wilson (1930) recorded six prehistoric sites in Bastrop County, however, the site descriptions and localities are poorly documented. In 1953, T. N. Campbell and E. B. Jelks excavated two Late Prehistoric burials at the Goodwin Site (41BP1). The skeletal remains 
were observed in direct association with ceramic sherds and Scallorn arrow points (Texas Archeological Site Data Form, on file at the Texas Archeological Research Laboratory-University of Texas at Austin [TASDF, TARL]).

\section{0-1970 Investigations}

In 1962, the University of Texas Anthropological Society (UT-TAS) conducted archaeological investigations within Bastrop County that resulted in the documentation of previously unrecorded sites. During this survey, UT-TAS (Davis 1964) documented two Late Prehistoric burials (and associated artifacts) at the McCormick Site (41BP43). UT-TAS also documented a Late Prehistoric campsite (41BP55) southeast of Sayersville (Brown 1966; Hester 1966). 41BP55 lies in a plowed field near the confluence of Harris Creek and Big Sandy Creek, and was considered to have good potential for further investigations (TASDF, TARL). In 1968, UT-TAS conducted excavations on 41BP62, 41BP63, and 41BP64, recovering cultural materials associated with the Archaic through Late Prehistoric periods from all three sites (Malone 1968).

\section{0-1980 Investigations}

During the mid-seventies, UT-TAS began conducting investigations in Bastrop County, including a survey in 1975 of 160 acres on Camp Swift, resulting in the recording of 41BP68, a prehistoric chert scatter (Fawcett 1975). Subsequent surveys by UT-TAS within Bastrop County in 1976 and 1979 were limited to a reconnaissance level(Dibble 1976; Dillehay 1979).

In 1979, at the request of the Lower Colorado River Authority (LCRA), Skelton and Freeman (1979) investigated 4,000 acres to be impacted by a proposed lignite surface mine within Camp Swift. This intensive survey resulted in the discovery of 42 prehistoric sites and 43 historic sites. According to
Skelton and Freeman, the majority of sites at Camp Swift located on upper terraces and active floodplains had a higher degree of integrity than sites located on valley margins and upland divides. Skelton and Freeman's 1979 survey forms the basis for Camp Swift archaeological site data from which past and present archaeological work draws.

\section{0-1990 Investigations}

The Center for Archaeological Research (CAR) at the University of Texas at San Antonio performed a reconnaissance level survey of 1,900 acres in northern Bastrop County, and a small part of Lee County during July of 1980. CAR performed the survey for City Public Service (CPS) of San Antonio in order to locate any cultural resources that would be impacted by proposed lignite mining. This investigation resulted in the discovery of five prehistoric sites (41BP199, 41BP204-206, 41LE63) and four historic sites (41BP200-203) (Kelly and Roemer 1981).

In May and June 1983, CAR conducted a 117 acre pedestrian survey within the CPS Butler Lignite Prospect for the City of San Antonio (Brown 1983). During this survey, five prehistoric sites were recorded. Two of these sites contained mixed prehistoric and historic materials. Three of the five sites (41LE73, 41BP265, 41BP264) were recorded along hill ridges approximately 80 to 400 $\mathrm{m}$ from intermittent drainages. The remaining two (41LE74, 41LE75) are located along ephemeral drainages within $50 \mathrm{~m}$ of Willow Creek. One site (41BP264), located along a ridge $250 \mathrm{~m}$ from an intermittent drainage, produced tools that span the Late Archaic to Paleoindian time periods (i.e., Plainview, Pedernales, Clear Fork Tool).

In 1984, CAR performed an intensive cultural resources survey for the City of San Antonio on 2,433 acres of the CPS Butler Lignite Prospect in 
northern Bastrop and southern Lee Counties (Taylor 1987). Fourteen sites total were investigated, including three prehistoric sites consisting of light lithic scatters located in upland environments, along intermittent drainages. These three sites were tested using shovel probes, which provided no evidence of intact deposits. The three prehistoric sites (41BP271, 41BP272, 41LE85) were considered disturbed due to the lack of intact cultural features and heavily eroded surfaces (Taylor 1987).

In 1987, Espey, Huston \& Associates (EH\&A) surveyed a $4.5 \mathrm{~km}$ long $x 7.6 \mathrm{~m}$ wide area on the inside of the western perimeter fence along Highway 95 for a proposed water line running from Bastrop to Elgin(Moore 1987). The 4.5-km section ran from approximately the halfway point of the Camp to its northern boundary. They excavated 14 shovel tests along that portion and found no sites. Because the southern 4-km of right-of-way along the fence ran through a portion of the 4,000-acre surveyed by Skelton and Freeman (1979), EH\&A did not re-survey that lineal stretch, but did revisit 41BP139, a site recorded by Skelton and Freeman (1979).

From April to May 1989, LCRA conducted a survey and geomorphological investigation within a proposed 780-acre expansion to the Powell Bend II Lignite Prospect, the fourth investigation of this nature performed on this property (Nightengale et al. 1992). The 780-acre project area, adjacent to Camp Swift, has similar prehistoric cultural deposits, geomorphological, and paleoenvironmental records. Nine sites were recorded during the survey, two historic and seven prehistoric. Two of the prehistoric sites (41BP332, 41BP335) were located along opposing flood terraces of Harris Creek, which is an intermittent tributary of Dogwood Creek. The remaining five prehistoric sites (41BP330, 41BP331, 41BP333, 41BP334,
41BP338) are located along upland divides overlooking Harris Creek, and minor tributaries of Harris Creek. 41BP332, 41BP335, and 41BP331 were recommended for further work based on the cultural material recovered from shovel tests, and the presence of a Late Archaic, Ensor, dart point found on the surface of 41BP332.

\section{0-2003 Investigations}

In 1990 and 1991, LCRA conducted archaeological investigations on 350 acres of property and 4.5 miles of conveyance lines for the Camp Swift Regional Wastewater Project on land managed by the LCRA. During these investigations, fourteen sites were recorded, consisting of ten prehistoric and four historic sites. Four of the prehistoric sites (41BP359, 41BP360, 41BP366, 41BP367) are located along tributary banks, two on terraces (41BP363, 41BP364), two on a bluff/knoll setting (41BP358, 41BP365), and two sites (41BP361, 41BP362) are located on upland terrain. According to Nightengale and Moncure (1996), all the sites recommended for avoidance (i.e., 41BP358, 41BP359, 41BP360, 41BP363, 41BP364) contained intact buried deposits and thus should be regarded as highly significant.

A series of archaeological field projects were conducted on Camp Swift starting in the early 1990s. AGTX staff archaeologists conducted a series of surveys on Camp Swift in order to provide clearance for proposed training activities and facilities (Leshley 1994, 1996; Wormser 1993a, 1993b, 1994; Wormser and Leshley 1995; Stringer and Wormser 1996; Sullo and Wormser 1996). In August and September 1995, EH\&A conducted a cultural resources survey of ten seismic lines on Camp Swift in advance of a seismic exploration project for KCS Resources, Inc. During this project, a total of 520 shovel tests were excavated and seven new archaeological sites were discovered 
(Schmidt and Cruse 1995).

Later in 1995, EH\&A surveyed a linear rightof-way for a $138-\mathrm{km}$ transmission line rebuilding project that ran from south to north through the western portion of Camp Swift (Nash et al. 1995). Six new sites were discovered during this project. In April 1996, EH\&A surveyed 52.3 acres on Camp Swift for KCS Resources, Inc for the construction of four wellpads and connecting roads. No archaeological sites were recorded within the proposed construction area, and cultural resource clearance was recommended (Nash et al. 1996).

From November 1996 to July 1997, the AGTX conducted a pedestrian survey and limited shovel testing of 5,000 acres located at Camp Swift. During this investigation, 1,000 acres that had been previously surveyed by Skelton and Freeman in 1979 were revisited (Robinson 2001). An assessment of previously recorded prehistoric and historic sites for NRHP eligibility warranting further testing was included in this project.

In September of 2000, CAR excavated shovel tests on 41BP485 and 41BP487 and acquired GPS locations of 28 previously recorded sites (Robinson et al.2001). Geomorphological investigations during a 2000 survey by CAR included the excavation of 12 backhoe trenches and previously recorded data (Lim et al. 2000; Prochnow 2001).

According to Prochnow (2001), the deposits within Camp Swift generally have a low potential to contain buried intact archaeological deposits, given the factors of Late Holocene erosion and highenergy deposits along with intense bioturbation (Prochnow 2001). In 2001, Mauldin (2001) developed eligibility recommendations for all 168 re- corded sites within the Camp Swift boundaries. Twenty-two sites recorded during the 1997 AGTX pedestrian survey and 37 previously recorded sites were considered potentially eligible for the NRHP and warranted further testing (Mauldin 2001).

In November and December 2001, the Center for Archaeological Studies (CAS) at Texas State University conducted archaeological evaluations for the AGTX on 39 previously recorded sites located within Camp Swift (Nickels et al. 2003). Site relocation, mapping, and determining site boundaries, integrity, and significance were the primary goals of this project. Nine of the sites contain both prehistoric and historic components, and the remaining thirty sites have prehistoric components. Sites were classified as having minimal potential $(n=19)$, moderate potential $(n=7)$, or high potential $(n=13)$. These classifications were based on the presence or absence of stratified, intact deposits possibly containing datable features, and the possibility of contributing significant information toward recent research issues. All of the sites determined to have high potential are located in upland, ridge and or sideslope environments. Five out of eight moderate potential sites are located in upland environments, with the remaining three sites located along terraces and a drainageway.

As of January 21, 2004, there were 600 prehistoric and historic sites registered with TARL in Bastrop County, and prior to this current project, there were 170 known sites within the Camp. Although a review of survey reports indicates that 171 sites were documented, one of those (41BP383) is on land that has been sold by the AGTX, and is now on private property. With the discovery of 11 additional sites during this current project, there are now 181 known sites within the boundaries of Camp Swift. 


\title{
Chapter 4
}

\section{Research Design and Methods}

\author{
David L. Nickels and Antonio E. Padilla
}

\section{Research Design}

\section{Introduction}

In order to identify and address research issues pertinent to the project area, numerous publications describing previous archaeological investigations in and around Camp Swift were consulted. The Research Design portion of this chapter is divided into two sections. This first section discusses issues directly associated with the prehistoric period, while the second section deals with the occupation and development of land that is now Camp Swift during the historic period.

\section{Section I: Prehistoric Issues}

\section{Prehistoric Site Density and Distribution}

With the completion of this survey, all 11,500 acres of Camp Swift have been surveyed. Although today's survey standards and techniques are more stringent than those of 20-30 years ago, this is reasonable beginning from which to build a GIS database that can be used to examine settlement patterns and site distributions. By compiling the data obtained since the first formal survey of Camp Swift in 1979 (Skelton and Freeman 1979), we will be able to examine prehistoric site densities and distributions through time.

\section{Prehistoric Site Characteristics}

It is also possible to examine the similarities and differences in site size, features, artifact assem- blage (technology), and inferred activities associated with prehistoric occupations through time. The linkages between the organization of technology and settlement patterns is an obvious approach that can be employed (Henry 1989).

\section{Formation of the Sandy Mantle}

One important research issue that must be investigated on any archaeological project is the geological context of archaeological sites (Butzer 1982; Waters 1992). This usually involves a study of published geological and soil maps for the area under study, describing the sediments and soils observed at archaeological sites and nearby cutbanks, and placing the archaeological materials within this depositional context. The ultimate objective of this effort is to determine the potential for recovering archaeological sites in well-preserved buried contexts. Most sites have only a low potential for preservation because they exist on the surface or in eroded contexts, but it is critical to identify those few sites that are well preserved in order to efficiently use the limited resources spent on archaeological investigations.

It was anticipated that the shovel tests and backhoe trenches excavated during this survey project would compliment our current studies at Camp Swift and add to our knowledge of how the sandy mantle was formed in east Central Texas, as well as its potential for preserving or containing intact archaeological sites. 


\section{Depths of the Sandy Mantle}

Our current studies at Camp Swift involve not only an extensive examination of how the sandy mantle was formed, but also its depth over various landforms. The results from this survey project would add to the existing database, and contribute to refining a model that predicts site distribution and expected integrity.

\section{Section II: Historic Issues}

\section{Historic Spatial Relationships}

It was antcipated that additional historic sites would be found during the survey. The archaeological and archival investigations of these sites should help clarify the spatial relationships of early Euroamerican farming, ranching, and industrial activities in Bastrop County. It is currently understood that the project area was originally settled in the 1850s. As such, insights into the evolution of settlement patterns in the Camp Swift area through the beginning of WWII is probable.

\section{HistoricEconomic Activities}

Although historic structures have presumably been destroyed when Camp Swift was created, stone foundations could still be extant, covered by dense vegetation characteristic of the Camp. Artifact assemblages typically include ceramics, glass, and metal. Evidence obtained by careful documentation of structural remains and artifact assemblages could be used to infer the probable economic scale of the occupants. Placed within context, we should be able to better interpret the living habits of pre-Camp Swift landowners.

\section{Methods}

This project's objective was to locate all cultural resources within the 307-acre project area, using pedestrian survey methods, shovel tests, backhoe trenches, and archival research to locate and record any historic and prehistoric sites encountered. Cultural resource investigations were conducted under the direct supervision of the coprinciple investigator/project archaeologist. CAS excavated 668 shovel tests and nine backhoe trenches during this project.

\section{Prefield Planning}

Before the project began, the principle investigators discussed issues with Ms. Shellie Sullo from the AGTX Cultural Resources Office to refine fieldwork and reporting standards. Prior to initiation of actual fieldwork, detailed archival research, soil surveys, geologic and topographic maps, and aerial photographs were consulted to better understand the site potential in the project area. Reports of previous surveys (see background sections above, pages 20-23) were reviewed, and site descriptions from the various projects at Camp Swift were examined in detail. In addition, a review was conducted of the current literature for the North, Central and Northeast Texas Archaeological Regions. To insure systematic recording procedures, the co-principle investigator/project archaeologist met with each crew member before the fieldwork began to review artifact classifications and recording procedures.

\section{Site Types}

Based on these reviews a series of potential prehistoric and historic site types were identified. These site types are defined below.

\section{Prehistoric Site Types}

Prehistoric site types classified as either open campsites, lithic procurement sites, lithic scatters, and burial sites were identified during the surveys. Open campsites were identified by the presence of intact burned rock features or scattered fire-cracked rock, evidence of late-stage reduced lithics, and a 
wide variety of either chipped or ground stone tools. In some cases an open campsite had a combination of all three; in some cases a single hearth or scattered burned rock with only a few flakes was also typed as an open campsite. The key factor in classifying a site as an open campsite was the presence of burned rock.

Lithic procurement sites were identified on the basis of evidence that gravel deposits were used as a source of raw material. Within the gravels should be evidence of early stage reduction in the form of tested cobbles, minimally scarred cores, and large exterior flakes, and possibly quarry blanks broken during manufacture. Lithic scatters were typed based on the absence of campsite features and material, but with the presence of cores and flakes regardless of stages of reduction, possibly crudely flaked bifaces broken during manufacture, and possibly discarded broken tools. Rock cairns and conspicuous artificial dirt mounds and artificially sealed rock crevices should be considered as possible burial sites.

\section{Historic Site Types}

Early historic settlement in the region would be represented by wooden or stone above-ground structures. Later industrial operations included lignite and clay mining. In these contexts, historic properties could be typed as mines, open pits, associated mine structures and constructed features, farmsteads, trash dumps, and individual burials or cemeteries. Isolated properties could include windmills, wells, cattle pens and dipping vats, and irrigation ditches to name a few.

\section{Fieldwork}

Fieldwork was conducted by staff archaeologists under the direct supervision of the project's co-principleeinvestigator/project archaeologist. The fieldwork consisted of a 100-percent pedestrian survey, site documentation, limited surface collections, surface inventories, shovel tests, and backhoe trenches. In adhering to a limited collection policy, no prehistoric and historic artifacts were collected from the surface. Since the entire project area had less than 30 percent surface visibility, excavation of systematic shovel tests was necessary as deemed by SHPO Survey Standards in order to define any cultural resources within the project area. CAS archaeologists collected all prehistoric and selected historic cultural material recovered from shovel tests. In addition, attributes of surface artifacts were recorded on sites where they were visible.

\section{Pedestrian Survey}

The 307-acre project area was subdivided into 11 different areas labeled alphabetically areas A-K (Figure 4-1). This division of the project area was based on natural and man-made boundaries (i.e. creeks, roads, fences, tree lines). Using the boundaries as a starting point, and spaced no more than $30 \mathrm{~m}$ apart, the field crew surveyed the project area using hand held compasses following a bearing set by the project archaeologist. Depending on the vegetation (open grasslands, dense vegetation and wooded areas), individual transects were performed, or partnered transects were used (Figure 4-2). Transects were marked with flagging tape labeled according to area and transect.

\section{ShovelTests}

The project area was further divided with regard to shovel test density within areas designated as high, moderate, or low probability (Figures 4-2 and 4-3). These areas are assigned according to the geographic setting (i.e. floodplains, terraces, uplands). Much of the project area encompasses high and moderate probability locations such as promontories adjacent to second and third order streams, floodplains and lower terraces with prob- 


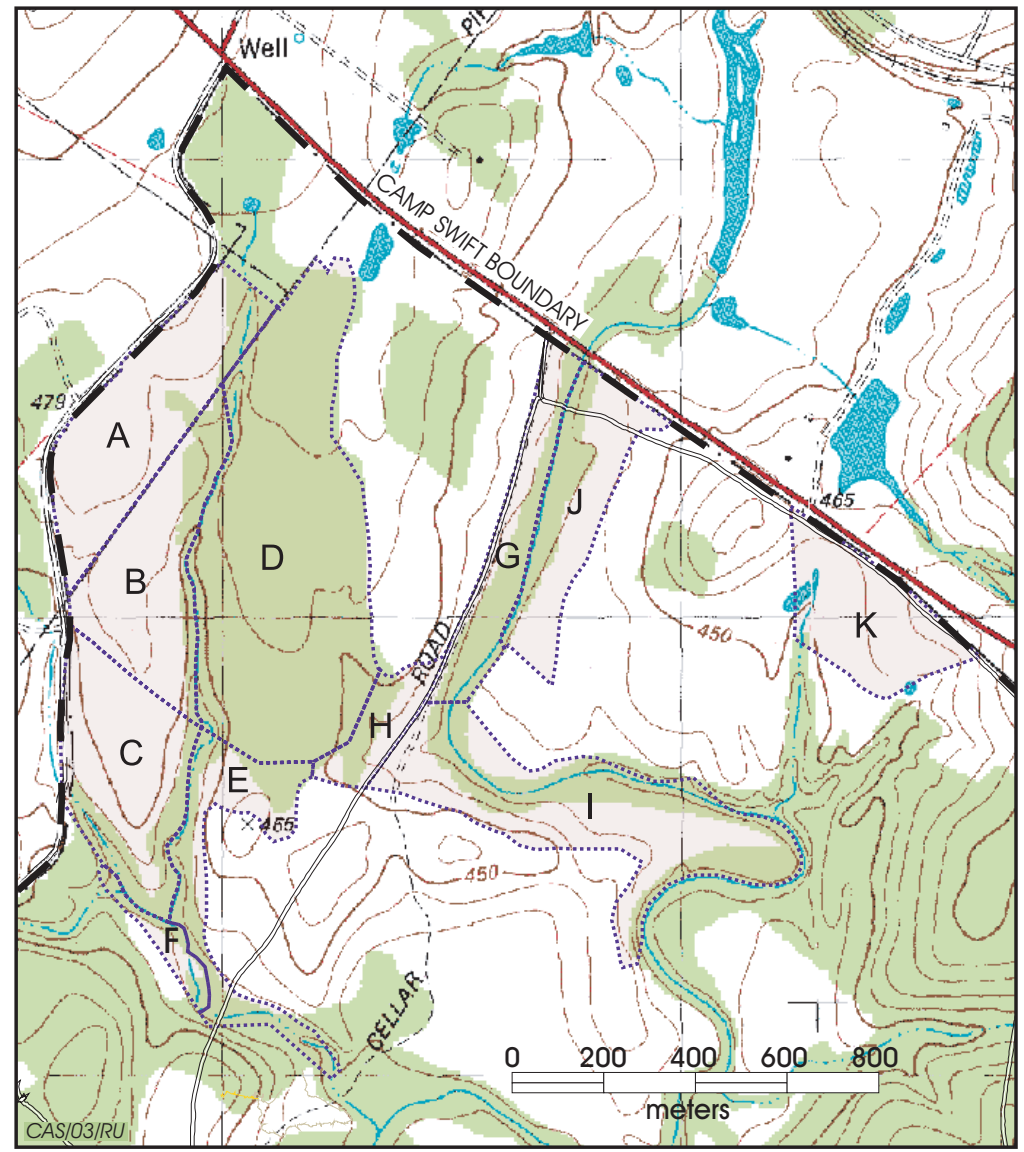

Figure 4-1. Project map showing designated survey areas for management purposes.

able deep alluvium, and/or upland areas that are in the general vicinity of such streams but at greater distance from channels. Low probability areas are restricted to generally flat, open regions away from streams and/ or hilltops and knolls. Very few areas appear to have been heavily disturbed either through erosion or artificial processes; much of the acreage is densely wooded. In addition to shovel tests and regardless of the probability for sites, emphasis was placed on the inspection of cutbanks, roadcuts, treefalls, gotransects. pher mounds, and any burrows.

Spacing within different probability areas was maintained while CAS personnel excavated systematic shovel tests across the project area. Shovel test intervals were generally spaced in $120 \mathrm{~m}$ intervals within the low probability areas, and shovel test intervals were "staggered" meaning that two people parallel to each other in transect would place their first shovel test at different distances from the beginning of the transect and the remaining shovel tests on the two parallel transects would be spaced at a set distance of $120 \mathrm{~m}$. This created a grid-like pattern of shovel tests across the area as the survey proceeded (see Figure 4-3). In moderate probability areas shovel tests were gener-

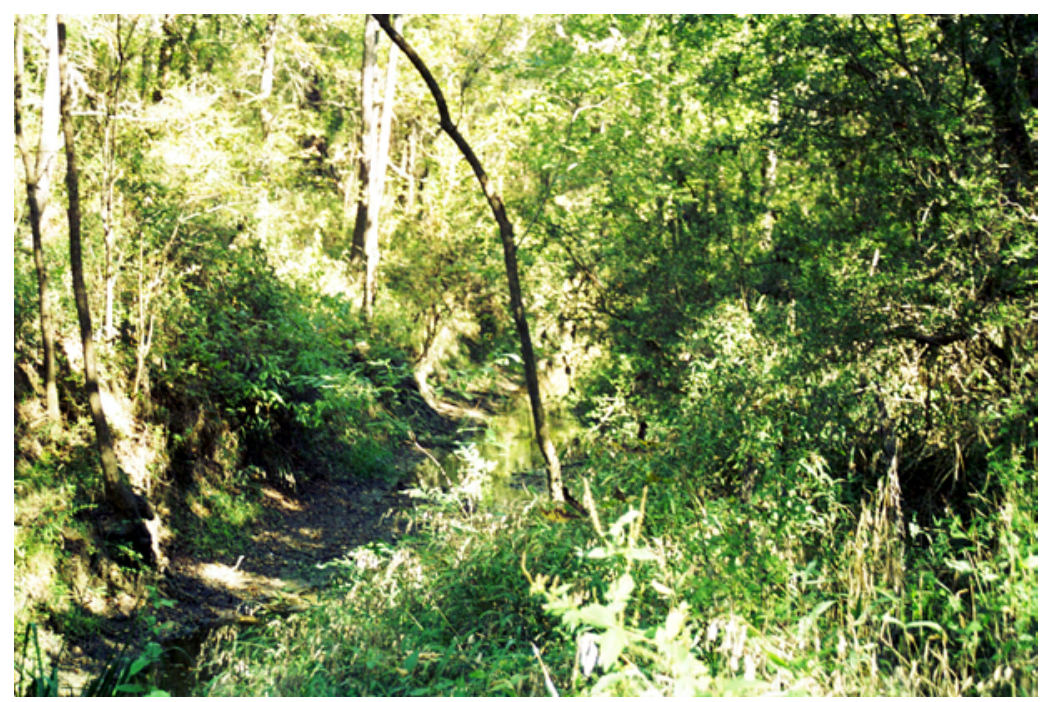

Figure 4-2. Areas of dense brush required two individuals to walk 


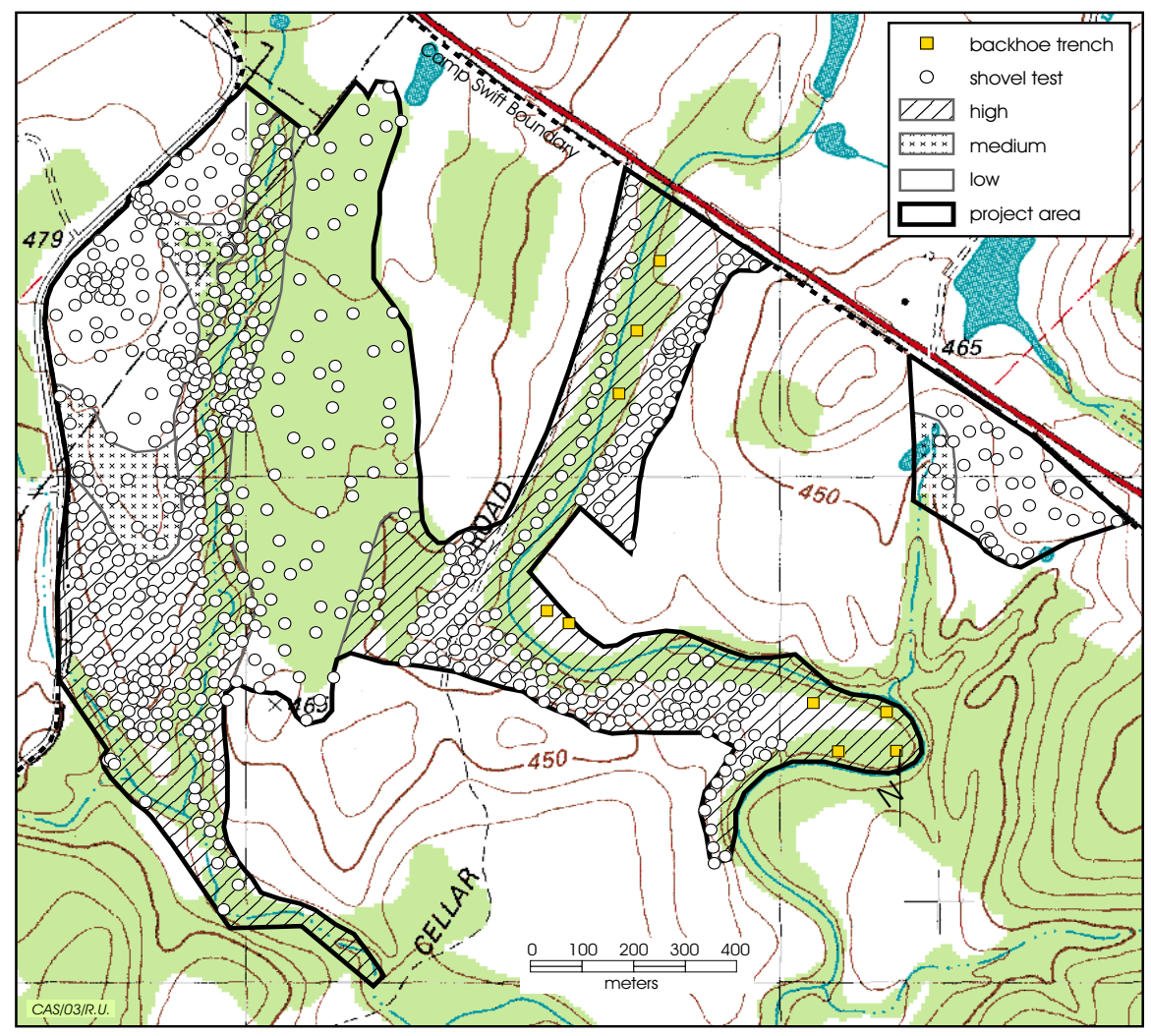

Figure 4-3. Project map showing areas of probability and shovel test locations. dard CAS shovel test forms and every shovel test was flagged with tape and labeled with Area, Transect, and Shovel Test number (e.g., Area B, L-2). All shovel test locations were recorded with a hand held Trimble $C$ GeoExplorer ${ }^{\circledR} 3$ Global Positioning System (GPS). A stick with flagging tape was placed upright in positive shovel tests to aid in relocation.

Heavily disturbed areas within the ally placed every $60 \mathrm{~m}$ while in high probability areas shovel tests were generally spaced $30 \mathrm{~m}$ apart.

Shovel tests were excavated approximately 30 $\mathrm{cm}$ in diameter, removing no more than $10 \mathrm{~cm}$ of matrix per level, and terminating at $100 \mathrm{~cm}$. Additional levels were removed if artifacts were encountered in what would be the standard bottom $100 \mathrm{~cm}$ level, and the potential for subsurface cultural strata was deemed high, as in alluvial or thicker, sandy sediments. In deep, sandy soils, shovel tests were generally terminated between 100 and $140 \mathrm{~cm}$ below the surface. All matrix removed was screened through 1/4-in wire mesh (Figure 4-4). All artifacts from shovel tests were collected, bags were labeled with their appropriate field provenience, and the artifacts were then transported to CAS for analysis and temporary curation. Each level removed was noted on stan- project area (i.e. caliche roads, pipelines) were not tested. However visual observations were still made in the disturbed areas, which usually had less vegetation cover.

\section{Backhoe Trenches}

Excavations using a backhoe in selected areas was conducted by the co-principle investigator/ geoarchaeologistin order to investigate soil profiles and record them using standard soil survey procedures. Salinas Brothers Hauling and Excavating provided the backhoe and operator to perform the trenching (Figure 4-5). All nine backhoe trenches were excavated to 2-3 $\mathrm{m}$ in depth and approximately $5 \mathrm{~m}$ in length. Two CAS archaeologists monitored the backhoe excavations and all sediments as they were removed (Figure 4-6). One wall from each trench was examined in detail by the project geoarchaeologist, and records including photographs, wall profiles, and geological soil zone 


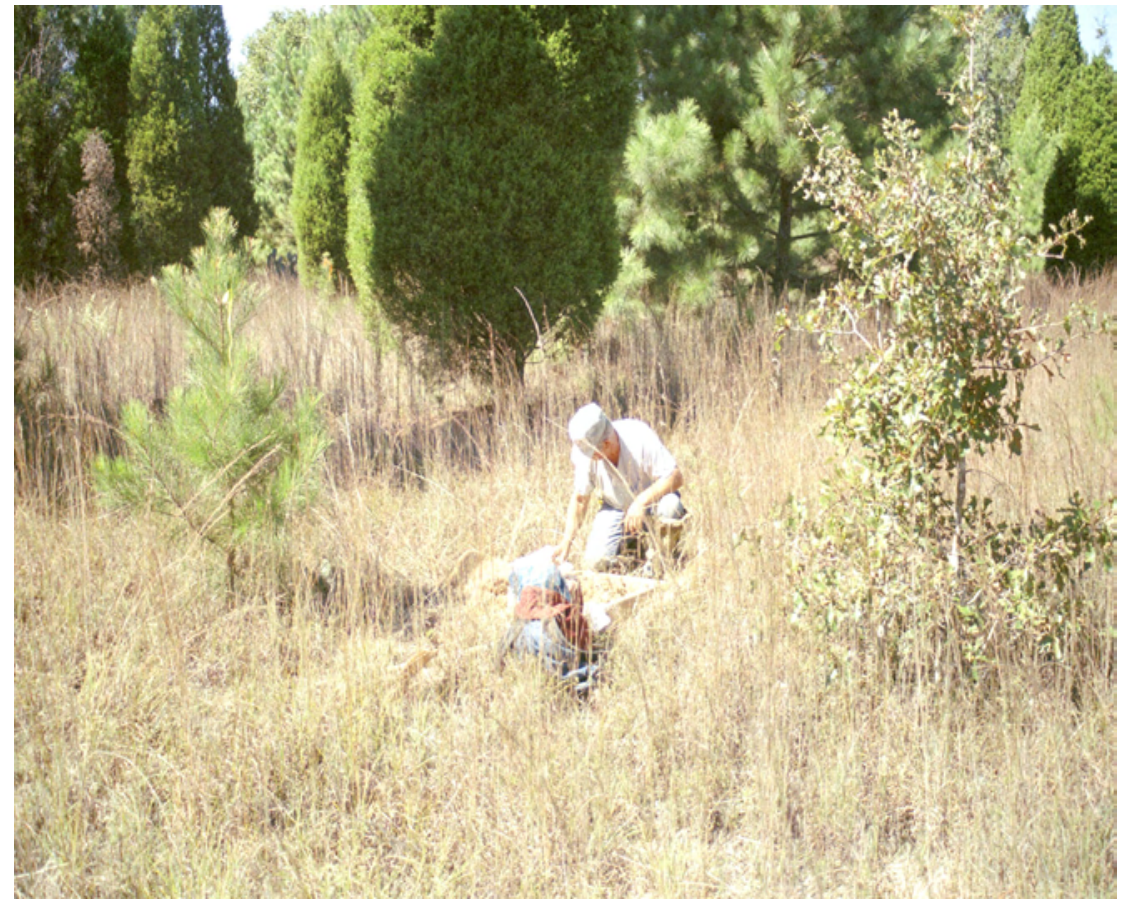

Figure 4-4. Shovel testing in Area C; all sediments were screened through 1/4-

the surface, site boundaries were initially established according to surface artifact distribution. Later, as shovel tests confirmed the presence/absence of subsurface cultural material, the boundaries were expanded accordingly; if sites were discovered through systematic shovel tests, the same rule applied. Crew members then rotated through the various tasks of properly documenting the site. Notes were made regarding site disturbance, vegetation, features, and pertinent landmarks visible from the site datum.

descriptions were made. A zone is a geological term used for labeling homogeneous sediment and/ or soil layers. Soil samples were taken from one wall of each backhoe trench for $\mathrm{pH}$ and magnetic susceptibility analysis.
To establish the site datum, a large nail and aluminum tag with field site number was hammered into a tree at the site's center or the best vantage point. USGS 7.5' topographic maps and a Trimble $(C$

\section{Documenting Sites}

An archaeological site was defined as having at least five artifacts in a $25 \mathrm{~m}^{2}$ area, or at least two positive shovel tests in the same area, or at least one cultural feature. Once a site was discovered, crew members intensively examined the ground surface, flagging artifacts, noting any highdensity concentrations. If artifacts were present on

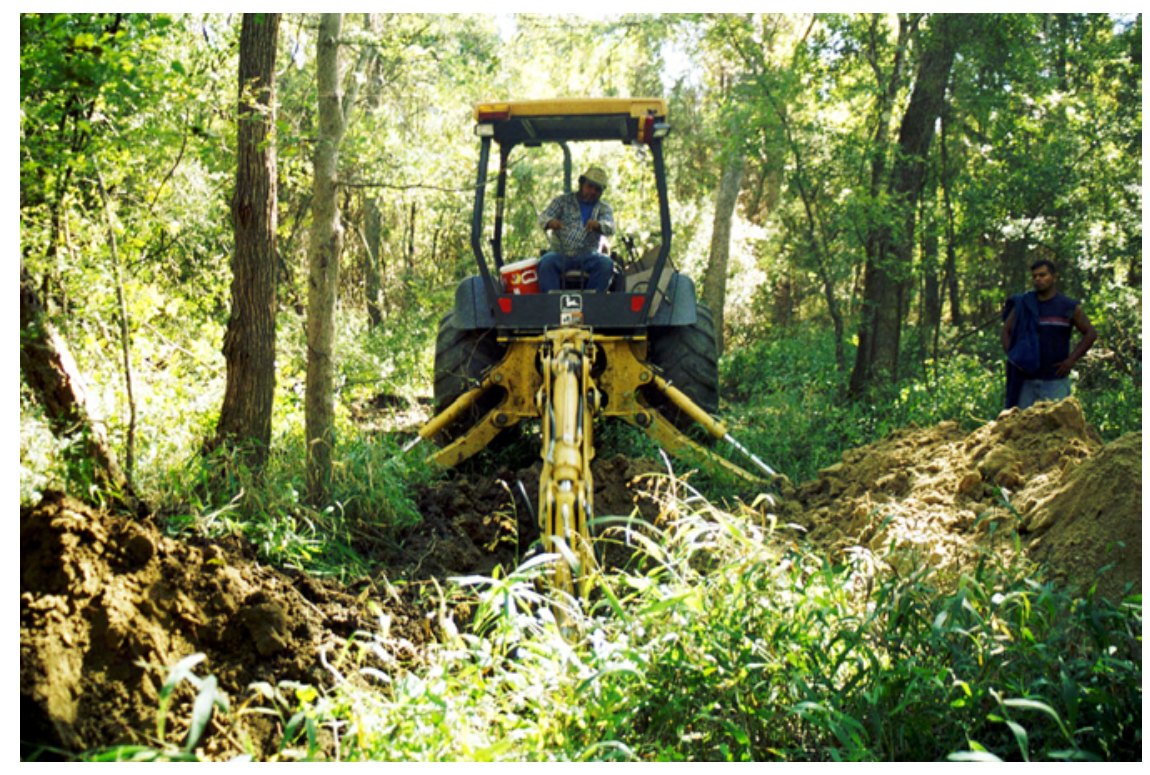

Figure 4-5. Armando Salinas conducted the trenching operations for the project. 


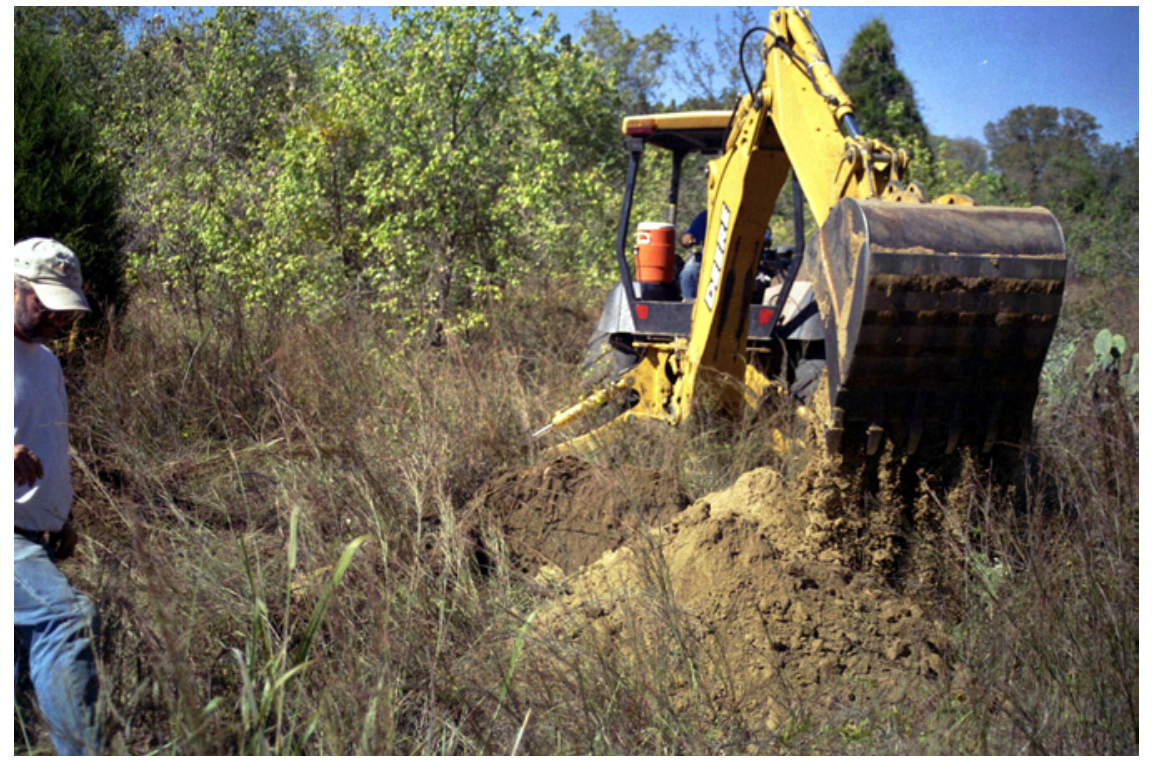

Figure 4-6. Monitoring backhoe trench excavations adjacent to Big Sandy Creek. and to develop a preliminary understanding of the nature of the soils and depositional history at the site. The results were then analyzed to evaluate the potential for buried, intact cultural deposits below any cultural material exposed on the surface.

All prehistoric artifacts from shovel tests and a few selected prehistoric surface items were collected. All historic artifacts discovered in shovel tests were recorded, but only selected historic artifacts from shovel tests and from the surface were collected. All collected artifacts are housed at TARL.

\section{Surface Observation Areas}

When visible, a 100 percent inventory of prehistoric artifacts was made. Each artifact was recorded on a standard form, specifying prehistoric flake types, cores, tested cobbles, bifaces, utilized and retouched pieces, ceramics, and diagnostic artifacts. On historic component sites, notes were made regarding the artifacts, and diagnostic attributes noted.

\section{Site Mapping and Photography}

Site maps, showing site boundaries, datum locations, shovel tests, sampled areas, collected items, features, areas of high artifact density, and physical features on the landscape were recorded. A field sketch map using a pace-and-compass method was prepared, while mapping data was also collected using the GPS. Landforms, roads, or streams that would be helpful in relocating the site were shown. Survey areas with site locations and 
boundaries were plotted on a field map and on 7.5' Series USGS quadrangles.

Archival quality $35 \mathrm{~mm}$ color prints and slides were made of all sites, features, and artifacts where appropriate. Photographs were recorded on standard CAS photo forms in the field. In addition to photographing general survey and excavation activities, particular attention was given to features such as hearths.

\section{Laboratory Methods}

Artifacts and samples were accounted for daily while in the field. Upon returning to San Marcos, cultural materials recovered during the project were inventoried at the CAS laboratory. All artifacts were then identified and analyzed. Lot numbers were assigned to artifacts in the lab. Artifacts and samples were separated by artifact type and recovery context to facilitate analysis. Processing of recovered artifacts began with washing and sorting into appropriate categories. This data was then entered into an Excel spreadsheet.

At the CAS lab all cultural material collected was prepared for storage in accordance with federal regulation 36 CFR Part 79, and in accordance with current TARL guidelines. Lithic, metal, and ceramic artifacts processed in the CAS laboratory were washed, air-dried, and stored in archivalquality bags (4 mil zip-lock plastic bags). Acid-free labels were placed in all artifact bags. Each bag was labeled with a provenience or corresponding bag number. Artifacts larger than a dime, and all tools had a small patch of acryloid B-72 applied in order to label with permanent ink which was then covered by a clear coat of acrylic. Other artifacts were separated by class and stored in acid-free boxes with standard labels.
Site Forms and Mapping

The information recorded in the field as well as preliminary analysis data derived in the lab were transferred to TexSite software "initial visit" forms for filing with TARL. Site and artifact data used in analyses were provided in database form compatible with Microsoft Excel. In addition to the general maps to be included in the final report, an additional sets of maps of the project area was prepared for the AGTX. These show the locations and site boundaries for all cultural resources in the inventory area, plotted on 7.5' Series USGS quadrangles.

\section{Chipped Stone Analysis}

Chipped stone pieces were categorized functionally as projectile points, preforms, drills, perforators, unifaces, and scrapers. Projectile points were generally assigned to a type based on the commonly accepted point typology developed for Central Texas (e.g. Turner and Hester 1999), but also with consideration of numerous published reports from the surrounding regions.

Scraper were determined upon the degree of retouch which is invasive enough to shape the edge. Not all unifaces are scrapers, however. Those with little edge modification remain classified as unifaces. Unifaces and bifaces that have been formally fashioned or shaped, and exhibited late stage, systematic sharpening and /or resharpening were categorized as scrapers.

Other pieces were categorized in terms of stage of reduction, such as cores, tested cobbles, quarry blanks, other bifaces, unifaces, and interior or exterior flakes. Quarry blanks are generally a thick biface, reduced to a middle stage, but can have some cortex remaining. Presumably they were reduced to make them easily transportable to areas where raw material was scarce (e.g., Nick- 
els et al. 1997; Nickels 2000:120-121). Other nondiagnostic bifaces include those in all stages of reduction that do not fit elsewhere. For purposes of this inventory, unifaces are flakes that have been modified, either expediently or moderately. Thus, the degree of retouch that could be determined macroscopically was considered. Expedient flake tools are those that have been utilized or have been minimally retouched, with no apparent attempt at shaping. Moderately retouched flakes are those that have been flaked to create an edge, but with no formal shaping.

\section{SoilMagnetic Susceptibility Measurements}

At the CAS lab, the soils were removed from bags and placed in plastic two-cm cubes. The cubes were labeled alphabetically in order to provide a cross reference with their provenience at the site. Each sample was then placed at room temperature in a Bartington magnetic susceptibility MS2B sensor, susceptibility values were displayed on an MS2 meter, and recorded in a computer database.

\section{pH Value Measurements}

The same samples collected for magnetic susceptibility analysis were then used to measure their $\mathrm{pH}$ values. Each sample was mixed with tap water in a beaker, and the 50/50 mix was stirred vigorously so that the soil was suspended in the solution. The $\mathrm{pH}$ values of the solution were then measured using a $\mathrm{pH}$ meter. The tap water alone was also measured. The $\mathrm{pH}$ value of the tap water that was $\sim 7.0$ (neutral) was then added or subtracted to the soil and water value.

\section{Curation}

Finally, all cultural material, field notes, forms, photographs, and drawings, along with a copy of the final report on acid-free paper, and computer disks pertaining to this project were stored in acid-free boxes at TARL. 


\title{
Chapter 5
}

\section{Site descriptions, Analysis, Recommendations, And Isolated Finds}

\author{
David L. Nickels, James E. Barrera, and Antonio E. Padilla
}

\section{Introduction}

This chapter provides a general description of the sites, and an analysis of the associated artifacts found during this project. At the request of the AGTX Environmental Resources Office, site locations are not included in this chapter; they are instead shown on a combined USGS topographic map within a pocket envelope attached to the back cover of this report. Site location information is restricted to protect sites. Access to this information must be granted by TXARNG or TARL.

As a matter of clarity, the survey areas designated for this project either slightly overlapped, or were on the periphery of previously surveyed areas (see Figure 2-2). As such, there are seven previously recorded sites either within or adjacent to the areas surveyed during this current project. They have all been fully documented, and we did not conduct any additional work at any of these seven sites. Their current status is shown in Table 5-1.

Eleven sites were discovered and tested during this project; seven of the eleven sites have prehistoric components only, two have both prehistoric and historic components, and two have historic components only (Table 5-2). The prehistoric component sites are discussed in Section I, followed by the historic component sites in Section II.

Table 5-1. Previously recorded sites either within or on the periphery of the current project's survey areas.

\begin{tabular}{|l|l|l|l|l|}
\hline \multicolumn{1}{|c|}{ Site } & \multicolumn{1}{|c|}{ Type } & \multicolumn{1}{c|}{$\begin{array}{c}\text { Level of } \\
\text { Investigation }\end{array}$} & $\begin{array}{c}\text { Current } \\
\text { NRHP Status }\end{array}$ & \multicolumn{1}{|c|}{ Reference } \\
\hline $41 \mathrm{BP} 471$ & Open Campsite & Shovel Test & $\begin{array}{l}\text { Potentially } \\
\text { Eligible }\end{array}$ & $\begin{array}{l}\text { Nickels and } \\
\text { Lehman 2003 }\end{array}$ \\
\hline $41 \mathrm{BP} 476$ & Lithic Scatter & Shovel Test & Ineligible & Mauldin 2001 \\
\hline $41 \mathrm{BP} 477$ & Open Campsite & Shovel Test & $\begin{array}{l}\text { Potentially } \\
\text { Eligible }\end{array}$ & $\begin{array}{l}\text { Nickels and } \\
\text { Lehman 2003 }\end{array}$ \\
\hline $41 \mathrm{BP} 479$ & $\begin{array}{l}\text { Historic } \\
\text { Homestead }\end{array}$ & Pedestrian & Ineligible & Mauldin 2001 \\
\hline 41BP481 & Historic Bridge & Pedestrian & Ineligible & Mauldin 2001 \\
\hline $41 \mathrm{BP482}$ & Historic Bridge & Pedestrian & Ineligible & Mauldin 2001 \\
\hline $41 \mathrm{BP483}$ & $\begin{array}{l}\text { Historic Trash } \\
\text { Scatter }\end{array}$ & Pedestrian & Ineligible & Mauldin 2001 \\
\hline
\end{tabular}


Table 5-2. Sites discovered during this project.

\begin{tabular}{|c|c|c|c|c|c|}
\hline Site & Prehistoric & Historic & Site & Prehistoric & Historic \\
\hline 41BP662 & $\begin{array}{l}\text { Open } \\
\text { Campsite }\end{array}$ & & 41BP668 & & Farmstead \\
\hline 41BP663 & & Farmstead & 41BP669 & Open Campsite & \\
\hline 41BР664 & $\begin{array}{l}\text { Open } \\
\text { Campsite }\end{array}$ & & 41BP670 & $\begin{array}{l}\text { Lithic } \\
\text { Procurement }\end{array}$ & Outbuilding, Dam \\
\hline 41BР665 & $\begin{array}{l}\text { Open } \\
\text { Campsite }\end{array}$ & & 41BP671 & Open Campsite & \\
\hline 41BP666 & $\begin{array}{l}\text { Open } \\
\text { Campsite }\end{array}$ & Farmstead & 41BP672 & Open Campsite & \\
\hline 41BP667 & $\begin{array}{l}\text { Open } \\
\text { Campsite }\end{array}$ & & & & \\
\hline
\end{tabular}

\section{Section I: Prehistoric Site Components}

\section{BP662}

\section{Description}

41BP662 (Figures 5-1 and 5-2) is a 641 square meters $\left(\mathrm{m}^{2}\right)$ prehistoric open campsite ranging in elevation from 427 to 431 feet. The site is situated on a terrace above the floodplain of Big Sandy Creek. Patilo complex (PaE) sandy soils cover the

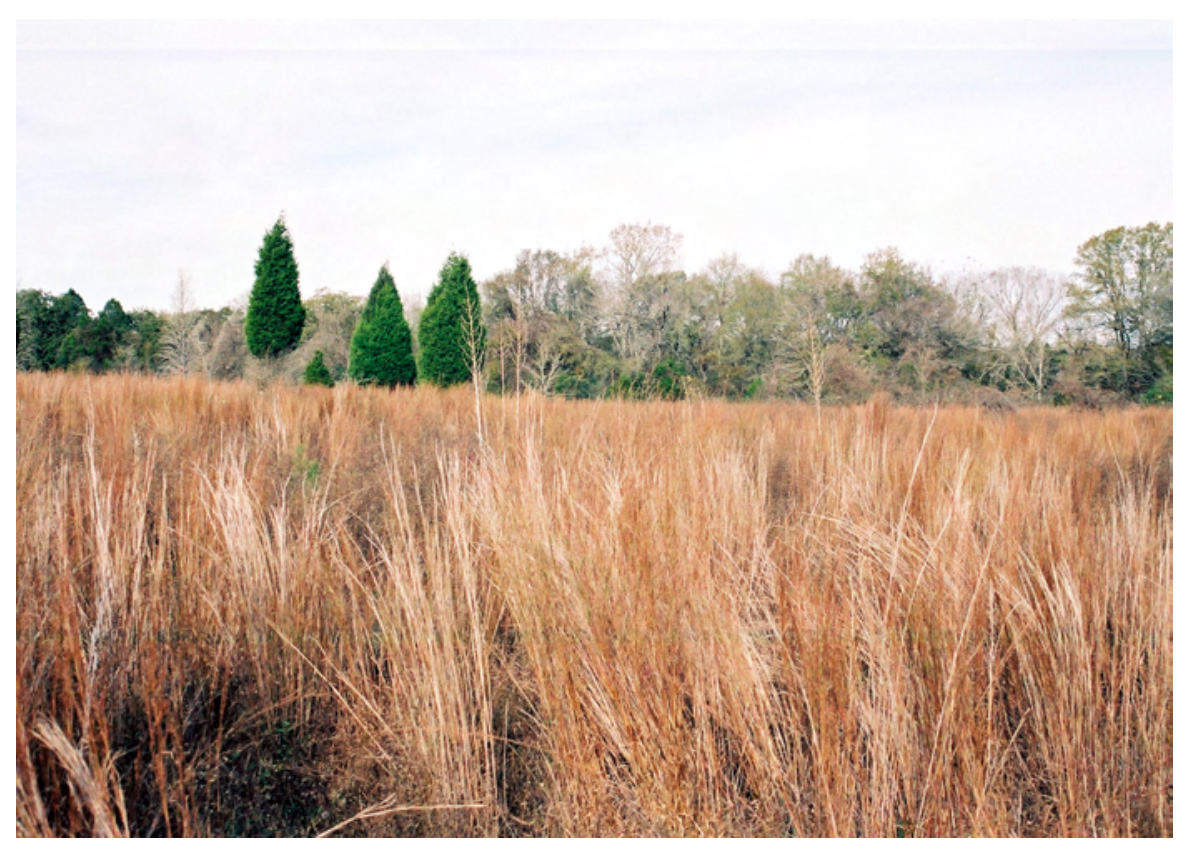

Figure 5-1. 41BP662 lies on a terrace of Big Sandy Creek; facing southwest. area and support waist-high grasses and weeds with scattered small cedar and pine trees. According to Mr. Abner Scott (personal communication, January 16, 2002), this site was cultivated by C. R. "Nick" Branton, a previous landowner. It is now overgrown with tall grasses and wild grapevines. The sandy soil is generally shallow and our shovel tests produced mottled gray and red clay near the surface, indicating that the area has been significantly disturbed. Our observations were that the general area had been disturbed in the distant past with earth moving equipmentas evidentby push piles, dirtmounds, and exposed clay patches. The nearest water source is Big Sandy Creek, approximately 90 meters (m) to the east. Surface visibility was less than five percent at the time of our September and November 2003 visits to the site. 


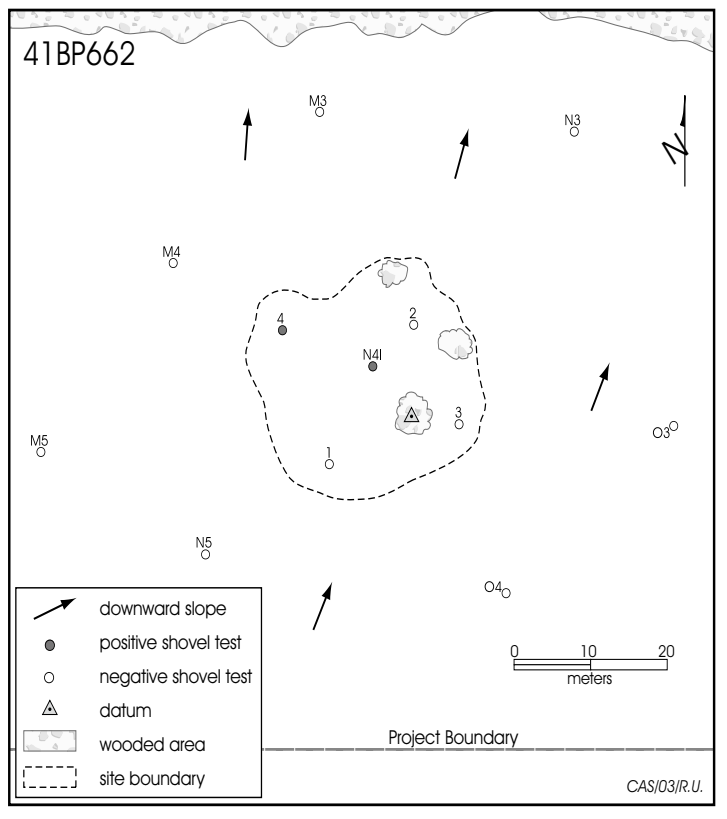

Figure 5-2. Site map,41BP662.

Levels of Work and Results

No artifacts were visible on the surface. This site was discovered in a high probability area near Big Sandy Creek during excavation of systematic shovel tests in 30 mintervals. Transect Shovel Test N4 in Area I (see Figures 4-2, 4-3 and 5-2) yielded an interior and exterior flake between 10-20 centimeters $(\mathrm{cm})$ below the surface.

Four additional shovel tests were placed within five meters in the four cardinal directions from
Shovel Test N4. The only possible cultural material recovered was a fire-cracked rock between 30-40 $\mathrm{cm}$ in Shovel Test 4. The results of shovel tests presented in Table 5-3 indicate significant subsurface disturbance has occurred at this site, with mottled clay present throughout Shovel Tests 1 and 3. Shovel tests placed around the site on Transects $\mathrm{M}$ and $\mathrm{O}$ were negative (see Figure 5-2).

Conclusions/Recommendations

In its current condition, it appears that this site was probably used as a short-term open campsite where limited lithic reduction activities occurred. An ephemeral remnant of the site (perhaps 10 percent) appears to remain intact, however, it is evident from shovel tests that the majority of the site has been heavily disturbed. Therefore we assess the research value of this site as a single entity to be minimal, and its value increases only slightly when considered in context with other small open campsites in the region. No further testing is recommended.

\section{BP664}

\section{Description}

41BP664 (Figures 5-3 and 5-4) is a 3,725 $\mathrm{m}^{2}$ prehistoric open campsite ranging in elevation from 472 to 475 feet (ft). The site is situated in a gradually

Table 5-3. Results of shovel tests at 41BP662.

\begin{tabular}{|c|c|c|c|c|c|}
\hline Depth $(\mathrm{cm})$ & ST N4 & ST 1 & ST 2 & ST 3 & ST 4 \\
\hline $0-10$ & & Clay Mottling & & & \\
\hline $10-20$ & 2 Flakes & Clay Mottling & Large Root & Clay Mottling & \\
\hline $20-30$ & & Clay Mottling & & Clay Mottling & \\
\hline $30-40$ & & Clay Mottling & & Clay Mottling & 1 Fire-Cracked Rock \\
\hline $40-50$ & & Clay Mottling & Orange Clay & Clay Mottling & \\
\hline $50-60$ & & Clay Mottling & & Orange Clay & Orange Clay \\
\hline $60-70$ & & Clay Mottling & & unexcavated & \\
\hline $70-80$ & Clay Mottling & Orange Clay & & & \\
\hline $80-90$ & Orange Clay & & & & \\
\hline & & & & & \\
\hline
\end{tabular}


sloping upland area, with a small, intermittent drainage approximately $20 \mathrm{~m}$ to the northwest. Axtell fine sandy loam (AfC2) covers the area and supports waist-high grasses, shrubs, weeds, and cacti, with scattered small cedar, and a stand of pine trees. The loamy soil is generally shallow, and shovel tests produced crushed gravels, indicating that the area has been significantly disturbed. Observations indicated that the general area had

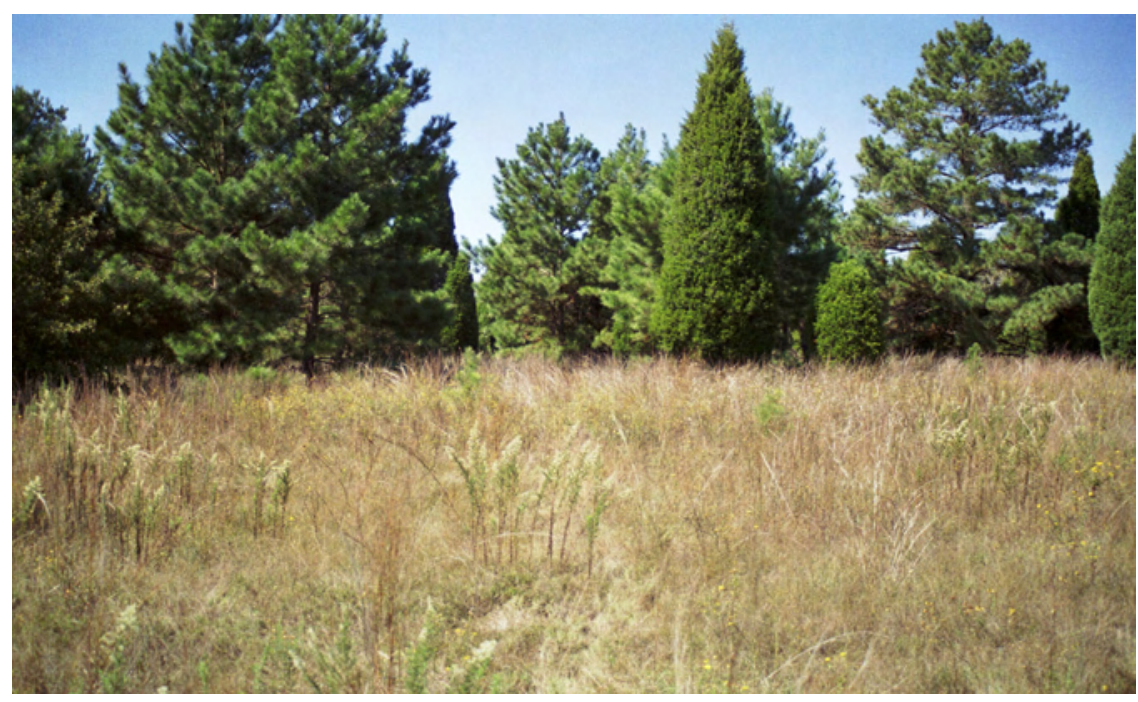

Figure 5-3. 41BP664 lies on an old, upper terrace and sideslope; facing west. in ever-expanding distances around Shovel Test P3 in order to define the site boundaries. The results of shovel tests presented in Table 5-4 indicate significant subsurface disturbance has occurred at this site, with crushed gravels, mottled clay, or petrified wood present in four shovel tests.

\section{Conclusions/Recommendations}

In its current condition, it appears that this site was probably used as a short-term open camp where limited lithic reductionactivities occurred. An ephemeral remnant of the site (perhaps 25 percent) appears to remain intact, however, it is evident from shovel tests that the majority of the site has either been heavily disturbed or lies within shallow soils. Therefore, we suggest that the research value of this site as a single

been disturbed in the distant past with earth moving equipment, push piles, dirt mounds, and exposed clay patches present. The nearest natural water source is Spring Branch Creek, approximately 150 $\mathrm{m}$ to the north. No artifacts were observed on the surface, but surface visibility was less than 10 percent at the time of October 2003 visit to the site.

\section{Levels of Work and Results}

No artifacts were visible on the surface, but this site was discovered during systematic excavation of shovel tests in a low probability, upland area away from any major drainage. Transect Shovel Test P3 in Area A (see Figures 4-1 and 5-4) yielded an interior flake between $0-10 \mathrm{~cm}$ below the surface. Thirteen additional shovel tests were placed

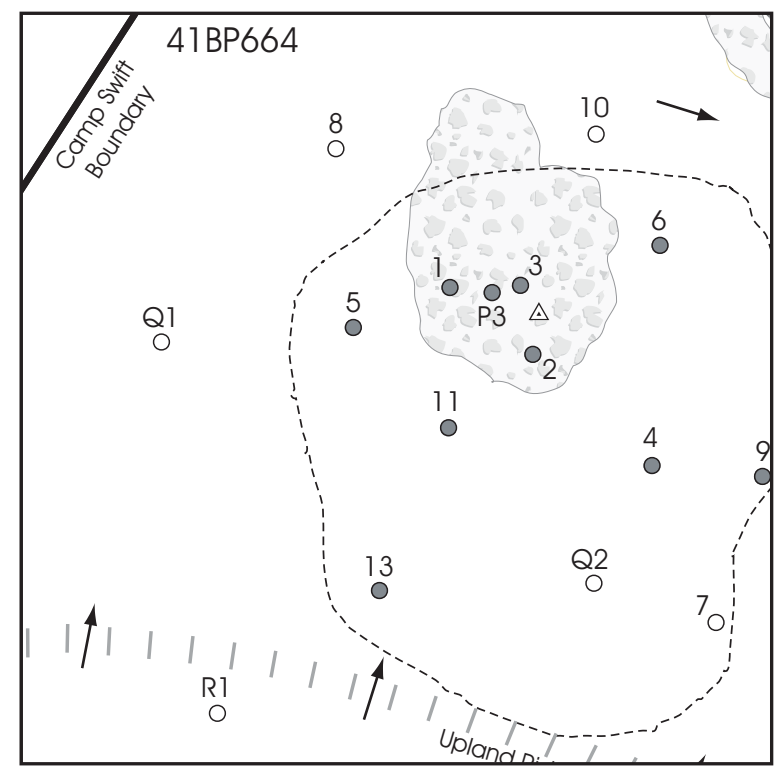

Figure 5-4. Site Map, 41BP664 
Table 5-4. Results of shovel tests at 41BP664.

\begin{tabular}{|c|c|c|c|c|c|c|c|c|c|c|c|c|c|c|}
\hline Depth $(\mathrm{cm})$ & ST P3 & ST 1 & ST 2 & ST 3 & ST 4 & ST5 & ST 6 & ST 7 & ST 8 & ST 9 & ST 10 & ST 11 & ST12 & ST 13 \\
\hline $0-10$ & IF & $1 \mathrm{FCR} ; \mathrm{fcr}$ & & $\mathrm{Cr} \mathrm{Gr}$ & & $f c r$ & $H S$ & & & & & IF; fcr & & IF \\
\hline $10-20$ & & $\mathrm{Cr} \mathrm{Gr}$ & $S$ & & IF & $I F ; E F ; f c r$ & & Clay & Clay & $F C R$ & & $f c r$ & & IF; HS \\
\hline $20-30$ & & $\mathrm{Cr} \mathrm{Gr}$ & Mottling & $H S$ & IF & $f c r$ & & & & & & Clay & & IF \\
\hline $30-40$ & Clay & Clay & Clay & FCR; fcr & & Clay & & & & Clay & & & & Clay \\
\hline $40-50$ & & & & Clay & & & FCR; PW & & & & Clay & & & \\
\hline $50-60$ & & & & & & & & & & & & & Clay & \\
\hline $60-70$ & & & & & Clay & & IF; fcr & & & & & & & \\
\hline $70-80$ & & & & & & & $E F ; f c r$ & & & & & & & \\
\hline $80-90$ & & & & & & & Clay & & & & & & & \\
\hline & & & & & & & & & & & & & & \\
\hline & & & & & & & & & & & & & & \\
\hline \multicolumn{15}{|c|}{ Key: CG - Crushed Gravel; EF - Exterior Flake; FCR - Fire-Cracked Rock >1"; fcr - fire-cracked rock <1"; HS - Heat Spall; } \\
\hline & IF - Inte & rior Flake; & DW - Petr & ified Wood & ; - & Shatter & & & - unex & xcavate & & & & \\
\hline
\end{tabular}

entity to be minimal, and its value increases only slightly when considered in context with other small open campsites in the region. No further testing is recommended.

\section{BP665}

\section{Description}

41BP665 (Figures 5-5 and 5-6) is a 2,829 $\mathrm{m}^{2}$ prehistoric open campsite ranging in elevation from 450 to $456 \mathrm{ft}$. The site is situated on a gradual sideslope and upper terrace adjacent to an unnamed, but deeply incised tributary. Axtell fine sandy loam (AfC2) covers the lower portion of the site adjacent to the stream, and Demona loamy fine sand $(\mathrm{DeC})$ makes up the upper portion of the site that lies on the sideslope. The area along the creek and south of an old fence line (see Figure 5-6) is heavily wooded with elm, pecan, and cedar trees. The area north of the fence line is mostly covered with thick grasses and scattered cedar trees. The marked contrast in vegetation suggests that the majority of the site has been cleared and farmed in historic times, and the site is now predominantly covered with old field growth. Gopher mounds were evident in the southeastern portion of the site only. No artifacts were observed on the surface, but surface visibility was less than 20 percent at the time of our October 2003 visit to the site.

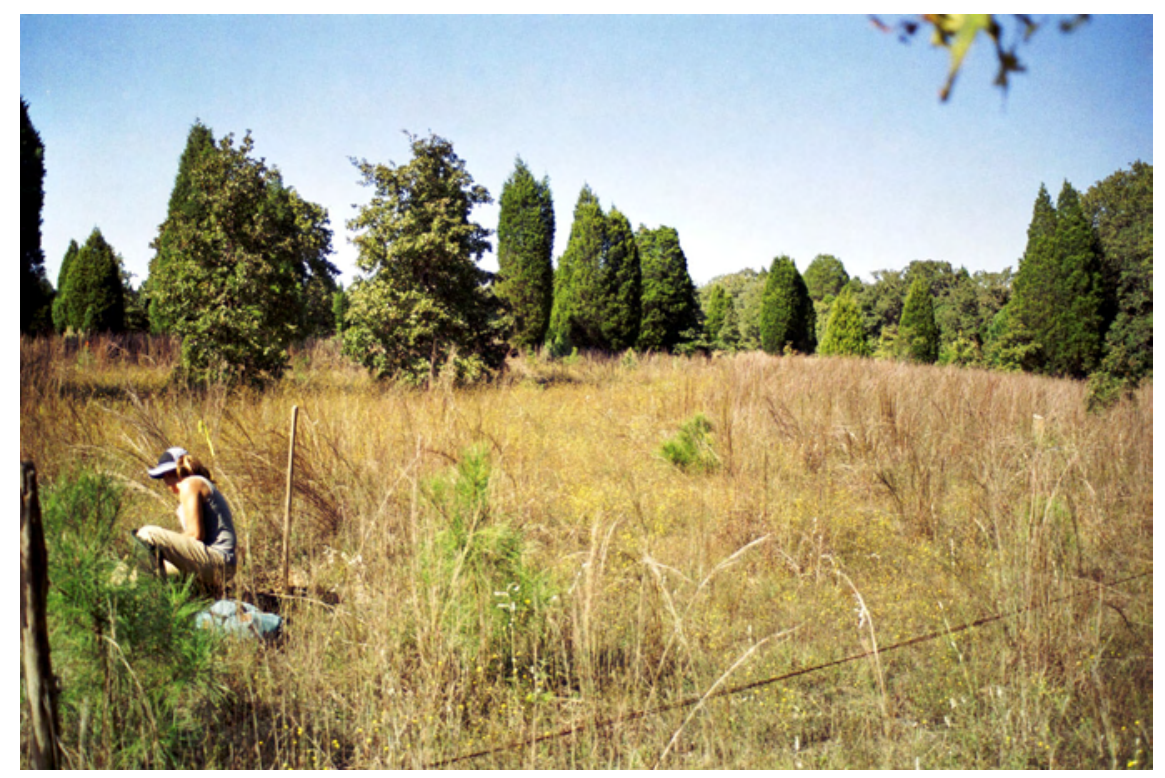

Figure 5-5. Melissa Lehman collecting information at a shovel test location on 41BP665, situated on an upper terrace and sideslope; facing northwest. 


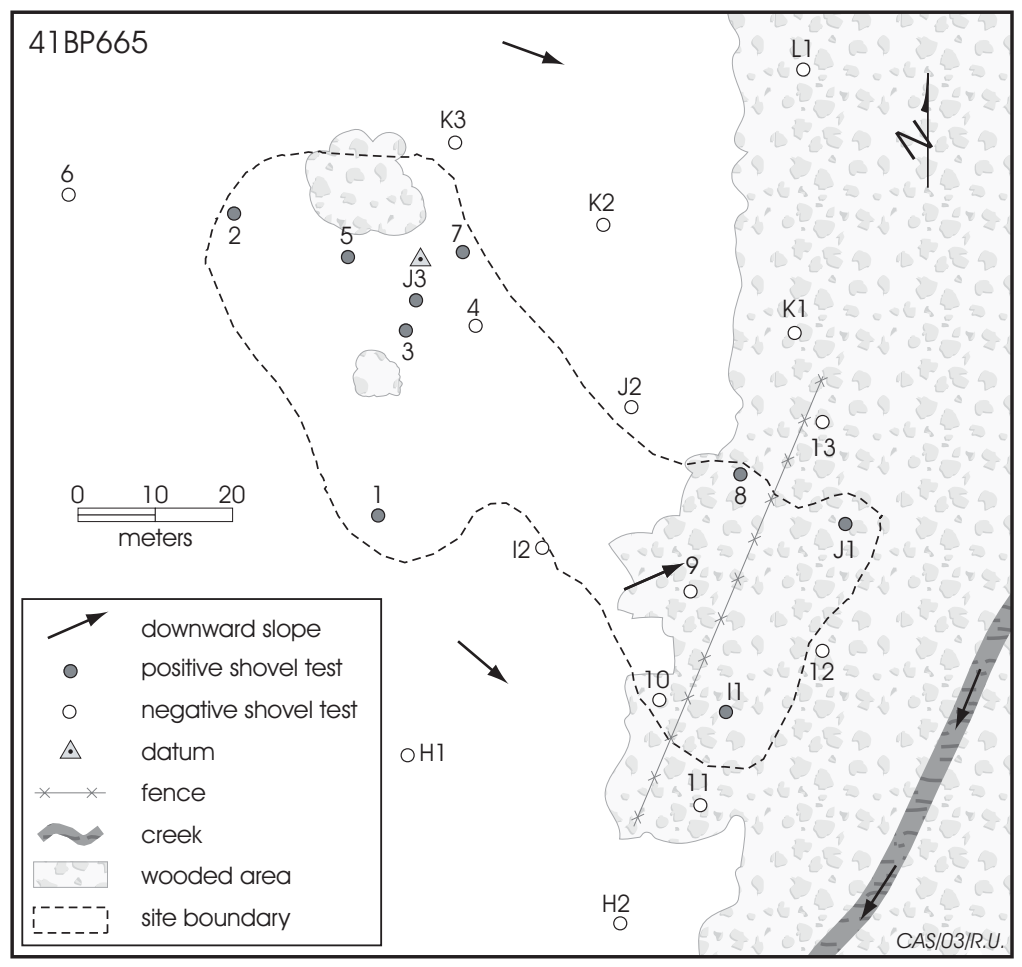

Figure 5-6. Site map, 41BP665

\section{Levels of Work and Results}

No artifacts were visible on the surface, but this site was discovered during systematic excavation of shovel tests in $30 \mathrm{~m}$ intervals in a high probability area adjacent to a major drainage. Transect Shovel Test J3 in Area B (see Figures 41 and 5-6) yielded four large fire-cracked rocks that appear to be part of a hearth feature between 60 $80 \mathrm{~cm}$ below the surface. A heat spall and a small piece of fire-cracked rock were also found in Shovel Tests I1 and J1, respectively. Thirteen additional shovel tests were placed in ever-expanding distances around Shovel Test J3 in order to define the site boundaries. In addition to the probable hearth feature, the results of shovel tests presented in Table 5-5 indicate possibly intact cultural deposits between $50-70 \mathrm{~cm}$ in Shovel Tests 2 and 3.

\section{Conclusions/Recommendations}

Although this site lies in what is apparently an old field, and presumably the upper ca. $30 \mathrm{~cm}$ may have been disturbed by plowing and rodent burrows in limited areas, the results from shovel tests suggest a possibly intact feature and associated debitage buried between $50-80 \mathrm{~cm}$ below the surface in the northern portion of the site, and the rodent burrows observed on the surface are approximately $30 \mathrm{~m}$ southeast of there. We recommend that a 1-x-1 mexcavation unit be placed in the immediate area of Shovel Test J3 to uncover the possible hearth remains as well as stratigraphic cultural data. We also recommend that three carefully excavated backhoe trenches be placed on the site in the areas of Shovel Tests 2 and 3 to further assess the integrity of this site. Any additional

Table 5-5. Results of shovel tests at 41BP665.

\begin{tabular}{|c|c|c|c|c|c|c|c|c|c|c|c|c|c|c|c|c|}
\hline Depth $(\mathrm{cm})$ & ST I1 & ST J1 & ST J3 & ST 1 & ST 2 & ST 3 & ST 4 & $\underline{\text { ST5 }}$ & ST 6 & ST 7 & \begin{tabular}{|l|} 
ST 8 \\
\end{tabular} & ST 9 & ST 10 & ST 11 & ST12 & ST 13 \\
\hline $0-10$ & & & & $f_{C r}$ & & & & & & $f_{c r}$ & & & & & & \\
\hline $10-20$ & & $H S$ & & & & & & & & & & & & & & \\
\hline $20-30$ & & & & & & $f_{c r}$ & & & & & & & & & & \\
\hline $30-40$ & & & & & & & & & Mottling & & & & & & & \\
\hline $40-50$ & $f c r$ & Clay & & & & & & $f C r$ & Mottling & & $f c r$ & Clay & & & & \\
\hline $50-60$ & Clay & & & & FCR & IF & & & Mottling & & Clay & & Clay & & & Clay \\
\hline $60-70$ & & & 2 FCR & & $H S$ & & & & Clay & FCR & & & & Clay & Clay & \\
\hline $70-80$ & & & $2 F C R$ & & & & Mottling & $f c r$ & & $f_{c r}$ & & & & & & \\
\hline $80-90$ & & & & & & & Mottling & & & & & & & & & \\
\hline $90-100$ & & & & Clay & & Sand & Mottling & Clay & & Clay & & & & & & \\
\hline $100-110$ & & & & & Mottling & & & & & & & & & & & \\
\hline & & & & & & & & & & & & & & & & \\
\hline \multicolumn{17}{|c|}{ Key: FCR - Fire-Cracked Rock >1"; fcr - fire-cracked rock <1"; HS - Heat Spall; IF -I nterior Flake } \\
\hline & & & & - unexce & & & & & & & & & & & & \\
\hline
\end{tabular}


cultural features identified in backhoe trench excavations should be investigated during the Phase II test excavation program.

\section{BP666}

\section{Description}

41BP666 (Figures 57 and 5-8) is a very large site, covering approximately $51,714 \mathrm{~m}^{2}(12.8$ acres), and ranging over a broad upland ridge and its sideslopes between two

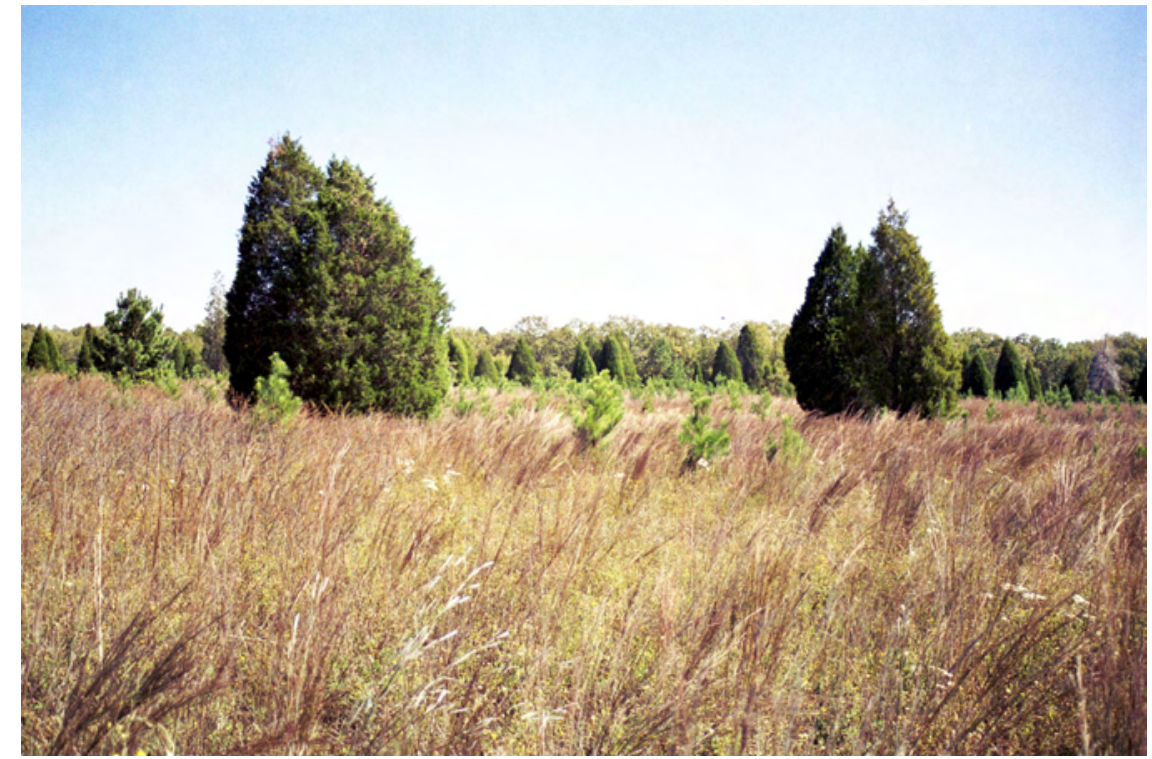

Figure 5-7. 41BP666 covers a broad upland ridge and sideslope between two drainages; facing northeast.

drainages. As such the site ranges in elevation from 450-465 feet. Deep, Patilo complex soils (PaE) cover the ridge, supporting tall scattered cedars, and a stand of large pine trees. The drainage along its southern edge is an unnamed intermittent drainage, that has catchment pools in sandstone bedrock and clay. The drainage on its northern edge is Spring Branch, a constantly flowing stream that locals say has never dried up, even in the worst droughts. At the confluence of these two drainages and below the end of this ridge is 41BP477, an open campsite deeply buried in terrace deposits. The settings for this site and 41BP477 are very similar FIGURE 5-8. REDACTED to that of 41BP486 and 41BP488 (see Nickels et al. 2003).

Because the ridge is now densely covered with vegetation, there are very few areas where surface visibility is greater than 5 percent. Although it is difficult to tell now, the ridge may have been farmed in historic times. There is a historic component at the northern edge of this site, and an old road runs along its northeastern portion (see Section II. Historic Components below). Erosional swales are present along its southeastern edge where the

Figure 5-8. Site Map,41BP666. 
elevation declines markedly. The only gopher mounds observed were outside the western edge of the site, around Shovel Test 14 (Figure 5-8).

\section{Levels of Work and Results}

This site was first encountered in its northern portion during systematic transect shovel test excavations. This area was initially assessed as a high probability area because of its ridge setting between two streams. We recovered three flakes from Shovel Test A1, with one from between 80$90 \mathrm{~cm}$ below the surface. Subsequent systematic shovel tests were ecavated in 30-40 m intervals to determined how large the site was, and defined a site boundary as well as discrete areas of prehistoric artifact concentrations within the boundary. For management purposes, we designated Areas $\mathrm{A}$ and $\mathrm{B}$ as distinct areas of concentration, and placed a sub-datum in Area B. In addition, we placed additional shovel tests between normal transect tests in order to better define Area B. Finally, a second sub-datum was placed in the northern, historic component of the site.

Only three prehistoric artifacts were found on the entire site's surface; an exterior flake $>3 \mathrm{~cm}$, a tertiary bifacial thinning flake $<2 \mathrm{~cm}$, and one firecracked rock. However, 39 of the 45 shovel tests placed on the prehistoric component of the site were positive. The only disturbance apparent in any of the site's shovel tests was evidenced by the presence of a bullet in the upper $10 \mathrm{~cm}$ of Shovel Test C30, a bullet between 10-20 cm in Shovel Test
4, and two pieces of barbed wire between $10-20 \mathrm{~cm}$ in Shovel Test A1. Table 5-6 presents the totals by category. Table 5-7 gives the results by individual positive shovel test.

Figures 5-9 through 5-12 show artifact concentrations below the surface. Figure 5-9 shows all chipped stone (debitage and tools) recovered from below the surface. Note that there are two discrete areas of concentration, with high nodes centered around Shovel Tests C 8 and 16, suggesting two loci where lithic reduction activities occurred.

If the ridge has been plowed, then the cultural material within the upper 20-30 cm may be horizontally displaced and dispersed, with undisturbed concentration areas. In this case, 29 of the 67 pieces (43.3 percent) of chipped stone recovered were within the upper $30 \mathrm{~cm}$. Figure 5-10 shows the distribution of those 29 pieces across the site. Note that in Figure 5-10, instead of two distinct high nodes as shown in Figure 5-9, there is now only one distinct high node, with four generally equal but dispersed nodes within the same general area as shown in Figure 5-9. The pattern shown in Figure 5-10 could depict undisturbed deposits representing many different loci; however, because of their shallow depth, we believe it probably represents cultural material horizontally dispersed by plowing.

Figure 5-11 shows the distribution of all chipped stone recovered below $30 \mathrm{~cm}$ across the site $(n=38)$. As in Figure 5-9, where two high nodes

Table 5-6. Totals of prehistoric cultural remains recovered from shovel tests at 41BP666.

\begin{tabular}{|c|c|c|c|}
\hline No. Items & No. Items & No. Items & No. Items \\
\hline 52 Flakes & $\begin{array}{c}\text { 9 Pieces of Lithic } \\
\text { Shatter }\end{array}$ & $\begin{array}{c}\text { 20 Fire-Cracked Rocks } \\
>1 \text { " in Size }\end{array}$ & $\begin{array}{c}\text { 2 Chunks of Burned } \\
\text { Clay }\end{array}$ \\
\hline $\begin{array}{c}5 \text { Utilized } \\
\text { Flakes }\end{array}$ & 1 Gound Stone Mano & $\begin{array}{c}46 \text { Fire-Cracked Rock } \\
\text { Pieces }<1 \text { " in Size }\end{array}$ & $\begin{array}{c}\text { 4 Charcoal Samples } \\
\text { (not collected) }\end{array}$ \\
\hline 1 Biface & 1 Smoothing Stone & 11 Heat Spalls & \\
\hline
\end{tabular}




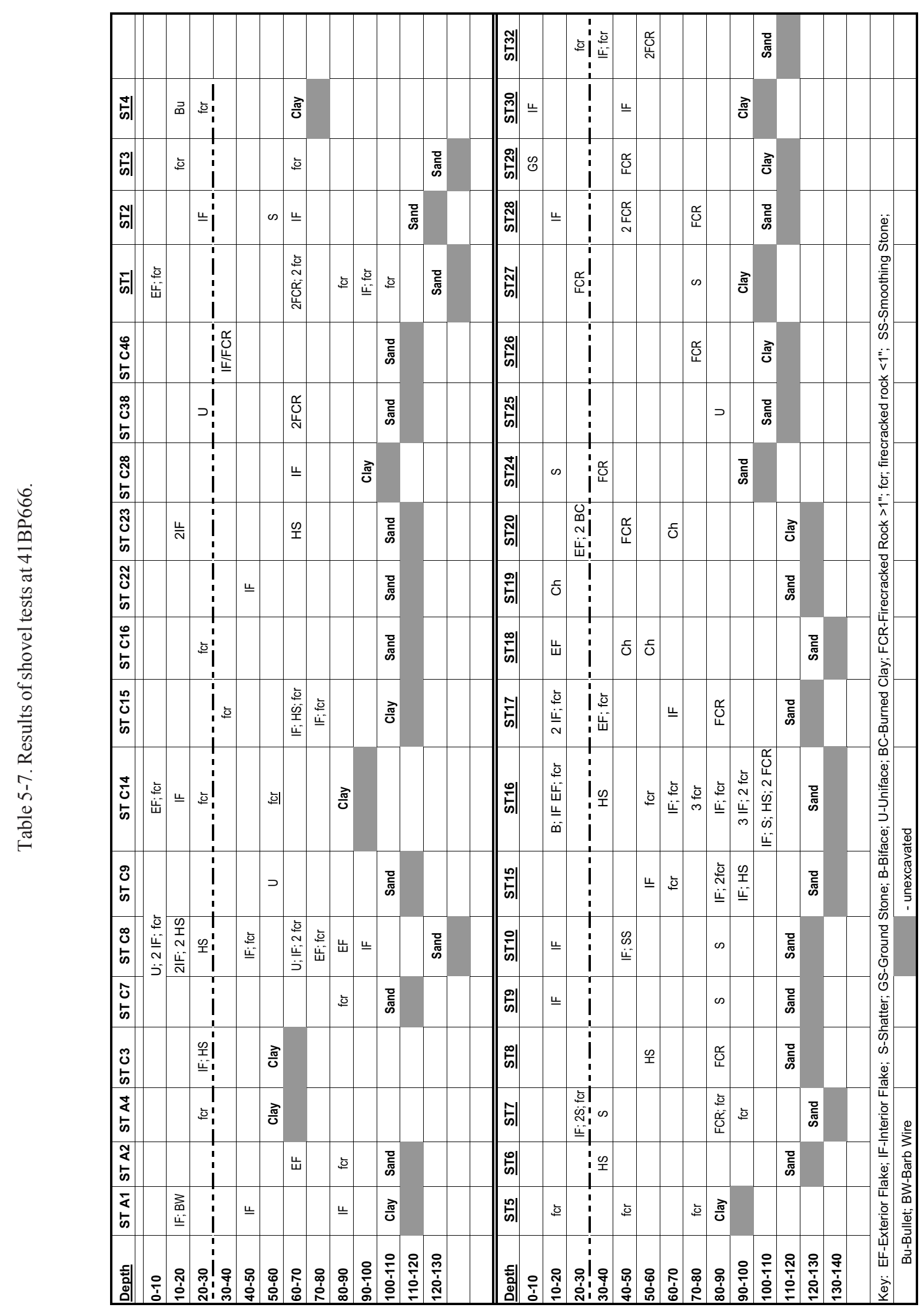


FIGURE 5-9. REDACTED

Figure 5-9. Distribution contours of all chipped stone artifacts from below the surface at 41BP666 $(n=67)$.

existed in the areas of Shovel Tests C8 and 16, there are two high nodes representing levels below $30 \mathrm{~cm}$ in those same areas. Even after removing artifacts that might have been disturbed by historic process in the upper $30 \mathrm{~cm}$, the data suggests that there are two distinct, and potentially intact cultural deposits below $30 \mathrm{~cm}$.

An examination of Table 5- 7 revealed that 18 out of the 19 fire-cracked rocks $>1$ " in size were recovered from below $30 \mathrm{~cm}$. Although admittedly problematic because of very low numbers in individual shovel tests, Figure 5-12 shows the distribution of those 18 fire-cracked rock, and depicts two
FIGURE 5-10. REDACTED

Figure 5-10. Distribution contours of all chipped stone within the upper $30 \mathrm{~cm}$ at $41 \mathrm{BP} 666(\mathrm{n}=29)$.

high nodes. One high node centers on Shovel Test 16 , the same shovel test that resulted in a high node for flakes below $30 \mathrm{~cm}$ (see Figure 5-10). Notably, no fire-cracked rock high node is associated with Shovel Test C8 (see Figure 5-10), but rather a high node in fire-cracked rock is present in the northwestern portion of the site around Shovel Test 1, and in the southern portion around Shovel Tests 28, 29 , and 32.

Figures 5-9 through 5-12 can be used to argue that disturbance probably occurred within the upper $30 \mathrm{~cm}$, probably due to plowing. These same figures can be used to suggest that there is a reasonable likelihood of finding intact features and associated cultural material below $30 \mathrm{~cm}$ in the areas of Shovel Tests 16 and C8 in the middle of the site, around Shovel Test 1 in the northern portion, 
FIGURE 5-11. REDACTED

Figure 5-11. Distribution contours of all chipped stone from below $30 \mathrm{~cm}$ across $41 \mathrm{BP} 666(\mathrm{n}=38)$.

and around Shovel Tests 28, 29, and 32 in the southern end of the site.

\section{Conclusions/Recommendations}

Even though this site lies in an old agricultural field, and presumably the upper ca. $30 \mathrm{~cm}$ has been disturbed by plowing, the results of shovel tests suggest three areas where possibly intact features and associated lithic artifacts are buried deeper than $30 \mathrm{~cm}$ below the surface. The area around Shovel Test 16 is especially worth further investigations because seven lithic artifacts and 10 pieces of fire-cracked rock were directly associated within single levels or interdigitated among levels between $50-110 \mathrm{~cm}$ below the surface. Other shovel tests that produced fire-cracked rock and lithic artifacts in direct association are Shovel Tests C8, C15, 1,
FIGURE 5-12. REDACTED

Figure 5-12. Distribution contours of all fire-cracked rocks greater than 1" in size across 41BP666.

15,17 , and 32 . We therefore recommend a minimum of nine backhoe trenches be excavated within those areas of concentration shown in Figures 5-11 and 5-12 to further assess the integrity of this site. The trenches should be carefully excavated in 3 to 5 -cm levels in a scraping fashion to expose possible burned rock features, artifact concentrations or preserved faunal material (even though none were recovered). Once exposed, the cultural materials should be manually excavated.

\section{BР667}

\section{Description}

41BP667 (Figures 5-13 and 5-14) is a small, $364 \mathrm{~m}^{2}$ prehistoric open campsite situated on a gradually sloping terrace made up of Sayers (Sa) 
fine sandy loam adjacent to Big Sandy Creek. The portion of the terrace where the site is located ranges in elevation from 428 to $432 \mathrm{ft}$. The lower, incised channel of Big Sandy Creek is about $40 \mathrm{~m}$ north of the site. The area along the creek is heavily wooded with elm, pecan, and cedar trees, while the site area is less densely wooded, giving way to tall grasses and scattered cedar trees. Surface visibility was less than 20 percent at the time of our October 2003 visit to the site.

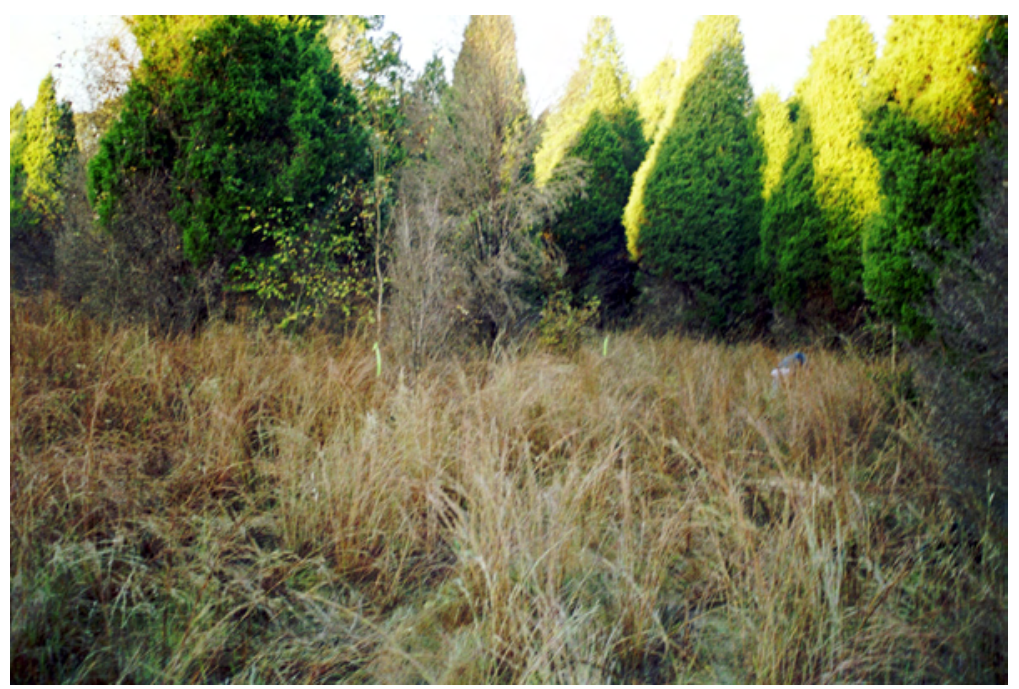

Figure 5-13.41BP667 is a small prehistoric open campsite situated on a gradually sloping terrace adjacent to a densely wooded area along Big Sandy Creek; facing southwest.

\section{Levels of Work and Results}

This site was discovered in systematic shovel tests ecavated in $30 \mathrm{~m}$ intervals within this high probability, terrace setting adjacent to Big Sandy Creek. Initially, we found an exterior flake between $60-70 \mathrm{~cm}$ in Shovel Test J14. We then placed an additional nine shovel tests around Shovel Test J14 in order to determine the site boundary as well as the depth of cultural material and soil type.

The results of shovel tests are shown in Table 5-8. A total of three flakes, a piece of lithic shatter, a tiny piece of fire-cracked rock, and a badly burned biface (possibly a dart point fragment) were found beneath the surface (see Figure 5-14). Although surface visibility was limited, three fire-cracked rocks were observed scattered in the shallow trench running along the eastern portion of the site (see Figure 5-14). Generally, soils are shallower on the northwestern portion of the site. The trench was approximately 20 $\mathrm{cm}$ deep and was cut into the

Table 5-8. Results of Shovel Tests at 41BP667.

\begin{tabular}{|c|c|c|c|c|c|c|c|c|c|c|}
\hline Depth $(\mathrm{cm})$ & ST J14 & ST 1 & ST 2 & ST 3 & ST 4 & ST5 & ST 6 & ST 7 & ST 8 & ST 9 \\
\hline \multicolumn{11}{|c|}{$0-10$} \\
\hline $10-20$ & & & & $S$ & & & & & & \\
\hline \multicolumn{11}{|l|}{$20-30$} \\
\hline $30-40$ & & $R F$ & IF & & & & & & $B$ & \\
\hline $40-50$ & & & & & & & & & & Clay \\
\hline $50-60$ & & & & & & & & Clay & & \\
\hline $60-70$ & EF & & & & Clay & Clay & Clay & & fcr & \\
\hline $70-80$ & Clay & Clay & Clay & Clay & & & & & Clay & \\
\hline \multicolumn{11}{|l|}{$80-90$} \\
\hline \multicolumn{11}{|l|}{$90-100$} \\
\hline \multicolumn{11}{|l|}{$100-110$} \\
\hline \multirow{2}{*}{\multicolumn{11}{|c|}{ Key: B - Biface; EF - Exterior Flake; IF - Interior Flake; RF - Retouched Flake; S - Shatter ; }} \\
\hline & & & & & & & & & & \\
\hline & fcr-fire- & cked rc & $<1 "$. & & - unexc & & & & & \\
\hline
\end{tabular}




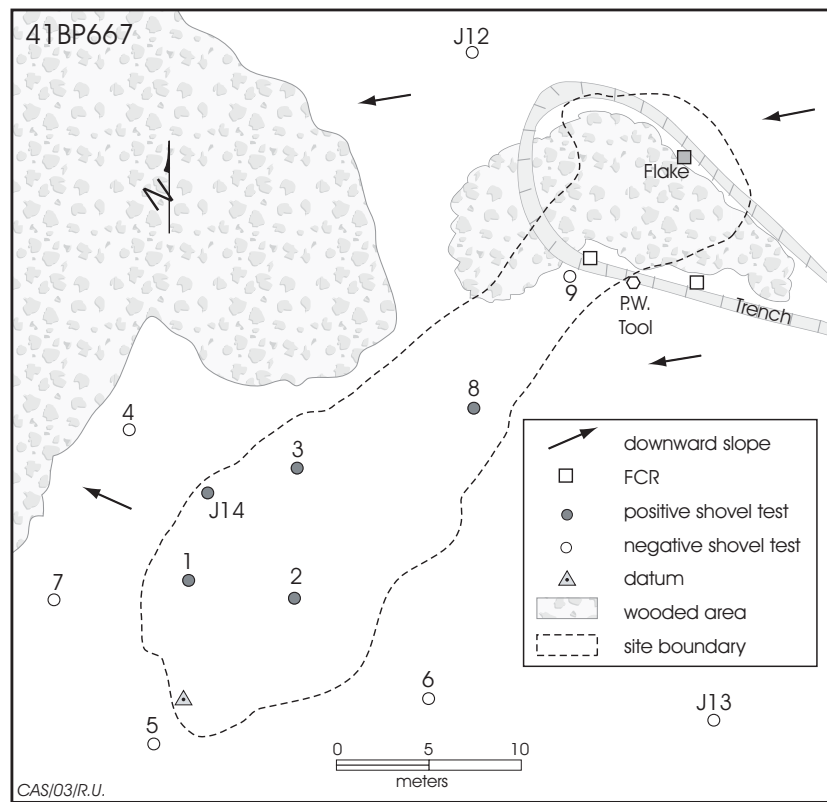

Figure 5-14. Site Map41BP667.

underlying clay (Bt) horizon. Otherwise, orange clay was exposed at the surface east of Shovel Test 9, and in a few areas around the trench.

A possible tool made from petrified or silicified wood was collected from the back dirt along the edge of the trench (Figure 5-15). Choppers and pressure flakers fashioned from silicified wood have been documented at the Chesser Site in nearby Lee County (Rogers and Kotter 1995:109112). A bifacial chopping or cutting tool was uncovered at 41GM224 in Grimes County to the northeast (Rogers 1994), and a silicified wood tool identified as a hammerstone was found at the Kennedy Bluffs Site in Bastrop County (Bement 1989:147148). Morphologically, the tool found at 41BP667 most closely resembles three tools identified as cobble flakers at the Chesser Site. It is $149 \mathrm{~mm}$ long, rectangular in cross section, and it has a series of stepped step fractures on its distal end, apparently caused by chopping. No other surface artifacts were observed.

\section{Conclusions/Recommendations}

Despite the trench disturbance, there may still be intact cultural deposits within this terrace deposit, especially between $30-40 \mathrm{~cm}$ below the surface around Shovel Tests 1, 2, and 8 . Notably, a retouched flake and a heavily burned biface were found at that level. The presence of fire-cracked rocks in the trench suggest that there may still be buried, intact hearth features at this site. Also, the presence of the petrified wood chopper suggests that this site might contain an unusual, perhaps unique, artifact assemblage that is not well documented in this portion of Texas, and this aspect supports the recommendation of fur-

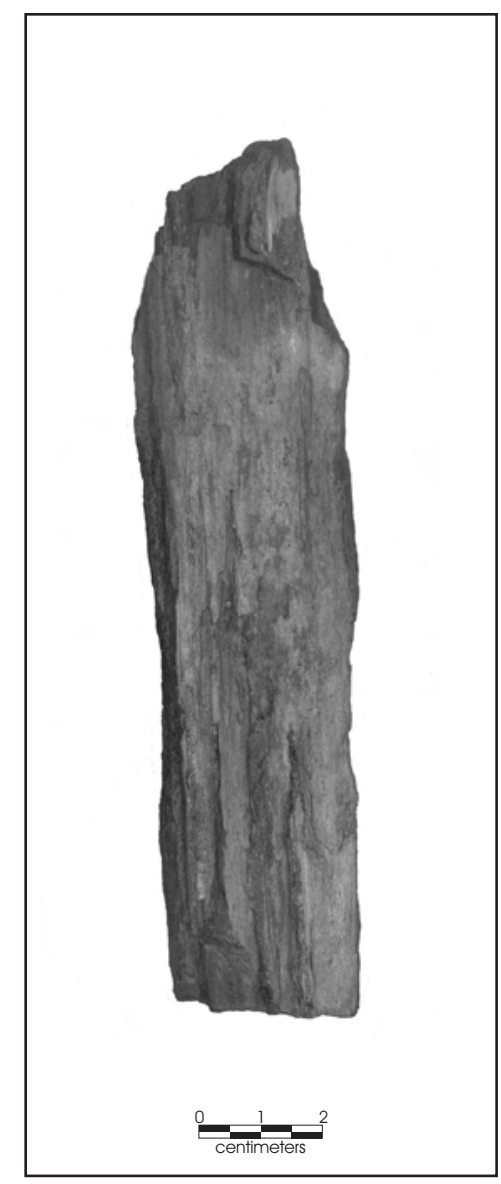

Figure 5-15. A petrified wood chopping tool was found on the surface of 41BP667. 
ther investigations. Because of the potential for intact features at a generally shallow depth $(30-40 \mathrm{~cm})$, in lieu of excavating backhoe trenches we recommend three 1-x-1 m excavation units should be used to further test this site.

\section{1ВР669}

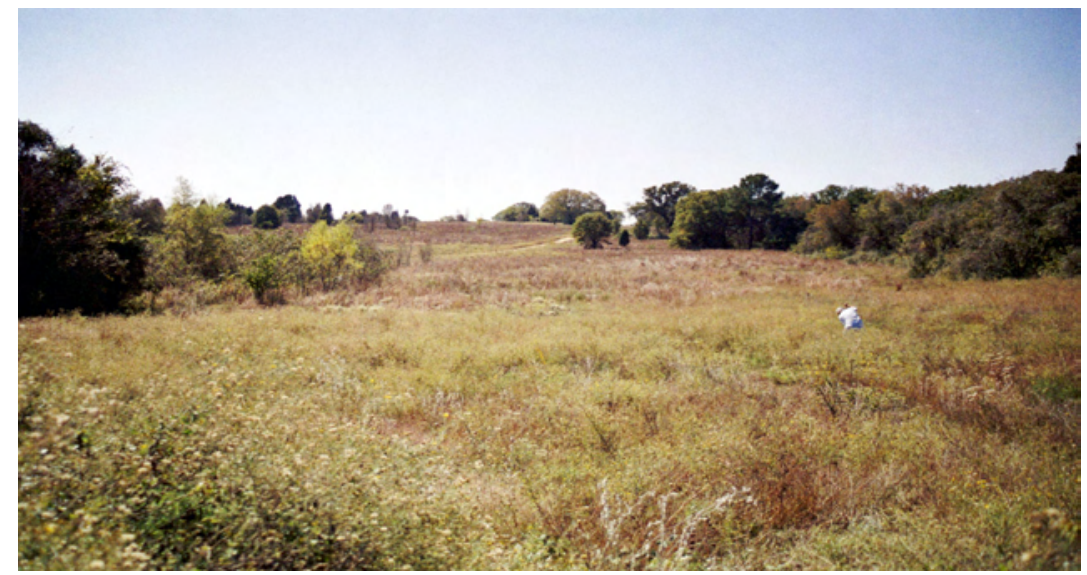

Figure 5-16. 41BP669 is a small prehistoric open campsite situated on a gradually sloping terrace adjacent to Big Sandy Creek; facing south.
41BP669 (Figures 5-16 and 5-17) is a $1,107 \mathrm{~m}^{2}$ prehistoric open campsite ranging in elevation from $435-445 \mathrm{ft}$. The site is situated on a sideslope above an outside meander of Big Sandy Creek, $75 \mathrm{~m}$ to the southeast. Demona loamy fine sand $(\mathrm{DeC})$ covers the area and supports waist-high grasses and weeds, with scattered small elm and cedar trees. Although the sandy soil is generally deep, our observations were that the general area has been disturbed. Tank tracks crisscrossed the site, and an old road depression was evident along a barbed wire fence running through the center of the site. Its southern edge has been disturbed by the construction of Wine Cellar Road. A sandy berm, possiblywindblown sand, has accumulated along the fence row, as is frequently seen in sandy areas. Surface visibility was approximately 15 percent at the time of our October 2003 visit to the site, and numerous rodent burrows were also visible.
41BP669

\section{Levels of Work and Results}

As with all prehistoric components found during this survey, 41BP669 was also discovered during systematic transect shovel tests. Materials

FIGURE 5-17. REDACTED

Figure 5-17. Site Map,41BP669. 
recovered in shovel testis are listed in Table 5-9. This area was considered a high probability area for site occurrence because of its proximity to a Big Sandy Creek upper terrace. Shovel tests were positioned in $30 \mathrm{~m}$ intervals. No artifacts were visible on the surface, but after cultural material was found in three transect shovel tests (A2, B1, B2), we excavated an additional seven shovel tests in order to determine the site's boundary and evaluate its integrity. Four interior flakes, a badly burned biface, two heat spalls, two pieces of lithic shatter, and two pieces of small $(<2.5 \mathrm{~cm})$ firecracked rock were recovered from the shovel tests (see Table 5-9).

\section{Conclusions/Recommendations}

As noted above, disturbances are clearly visible on the surface. Although shovel tests within the homogeneous sands did not reveal subsurface disturbance, the results likewise did not provide clear evidence of intact features or associated cultural material. As such, we assess the significance of this site as minimal, and therefore ineligible for nomination to the NRHP. No further work is recommended.

\section{BP670}

\section{Description}

41BP670 has a prehistoric lithic procurement component covering $1,200 \mathrm{~m}^{2}$, located at the confluence of two intermittent drainages (Figures 5-18 and 5-19) between 455-465 feet in elevation. Unfortunately, the area has been used in historic times as a gravel borrow pit and sandstone bedrock quarry. A sandstone structure and dam that comprise the historic structural component of this site are discussed below (Section II. Historic Components). Sandstone bedrock is prevalent on the banks and bottoms of both drainages. The larger drainage that courses along the southern portion of the site does not flow constantly, but has many catch pools. Although the soils are mapped (Baker 1979) as Axtell fine sandy loam (AfC2), there is little left on the site proper, and a sparse scatter of stone tools and debitage lies on the heavily eroded clay and gravel surface.

\section{Levels of Work and Results}

This site was discovered during the surface survey phase of the project while conducting

Table 5-9. Results of Shovel Tests at 41BP669.

\begin{tabular}{|c|c|c|c|c|c|c|c|c|c|c|}
\hline Depth (cm) & ST A2 & ST B1 & ST B2 & ST 1 & $\underline{\text { ST } 2}$ & $\underline{\text { ST } 3}$ & ST 4 & $\underline{\text { ST5 }}$ & $\underline{\underline{\text { ST } 6}}$ & ST 7 \\
\hline \multicolumn{11}{|l|}{$0-10$} \\
\hline $10-20$ & & & & & & & & & IF & \\
\hline $20-30$ & & & $H S$ & & & & & & & \\
\hline $30-40$ & & & $S$ & & & & & & & \\
\hline $40-50$ & & & & $H S$ & & & & & & \\
\hline $50-60$ & & fcr & IF & & & & & & $B$ & IF \\
\hline \multicolumn{11}{|l|}{$60-70$} \\
\hline $70-80$ & & & $S$ & & & & & & & \\
\hline $80-90$ & fcr & & & Clay Mottling & Clay & & & & & IF \\
\hline $90-100$ & & & & Clay Mottling & & & & & & \\
\hline $100-110$ & & Sand & Sand & & & Sand & & Sand & Sand & Sand \\
\hline \multirow[t]{3}{*}{$110-120$} & Sand & & & & & & Sand & & & \\
\hline & & & & & & & & & & \\
\hline & \multicolumn{4}{|c|}{ Key: B - Biface; IF - Interior Flake; S - Shatter; HS - Heat Spall; fcr - fire-cracked rock <1" } & Hents & inall. $f e$ & fir & rences & $\mathrm{rok}^{2}$ & \\
\hline & & - unexc & cavated & & & & & & & \\
\hline
\end{tabular}




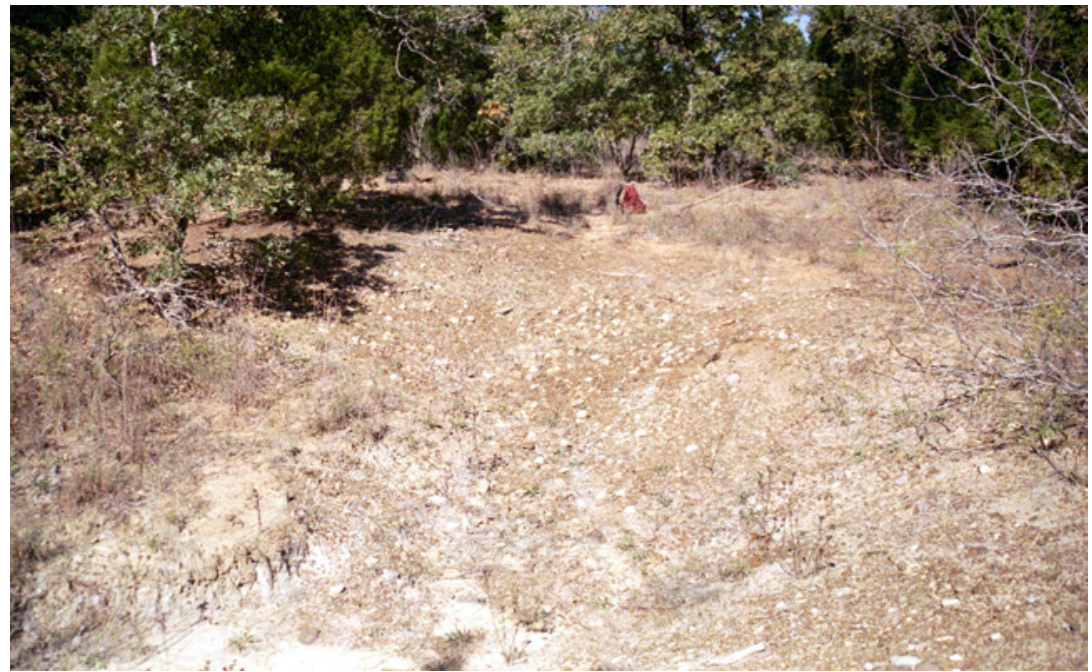

Figure 5-18. 41BP670 is an ephemeral scatter of chipped stone tools and debitage in a historic quarry with Uvalde gravels exposed; facing northwest.

transects in 30 mintervals in proximity to a substantial drainage. Because the small scatter of chipped stone lay on eroded clay and gravel surfaces amidst a much larger area of clay and gravel surfaces, gravel borrow pits, and quarried sandstone areas, we did not excavate shovel tests on the prehistoric component. Shovel tests higher up on the landscape around the historic component revealed red clay between $5-10 \mathrm{~cm}$ in all four tests. During a 100 percent surface inventory we documented one heat treated bifacial gouge slightly less than $5 \mathrm{~cm}$ long, a bifacial quarry blank approximately $10 \mathrm{~cm}$ long (Figure 5-20), one unifacially retouched flake $4 \mathrm{~cm}$ long, and four exterior flakes ranging between 3 and $9 \mathrm{~cm}$ long; no prehistoric artifacts were collected.

\section{Conclusions/Recommendations \\ Because of the highly dis- turbed nature of the prehistoric component of this site, its ability to}

contribute significantly to the prehistory of the area and region is minimal. The site's significance increases only slightly when considered in context with other sites in the area or region. Therefore, it is recommended ineligible for consideration for nomination to the NRHP and no further work on the prehistoric component is recommended.

\section{BP671}

\section{Description}

41BP671 is a large $\left(6,455 \mathrm{~m}^{2}\right)$ open campsite located on a wooded sideslope, ridge, and small

\author{
FIGURE 5-19. REDACTED
}




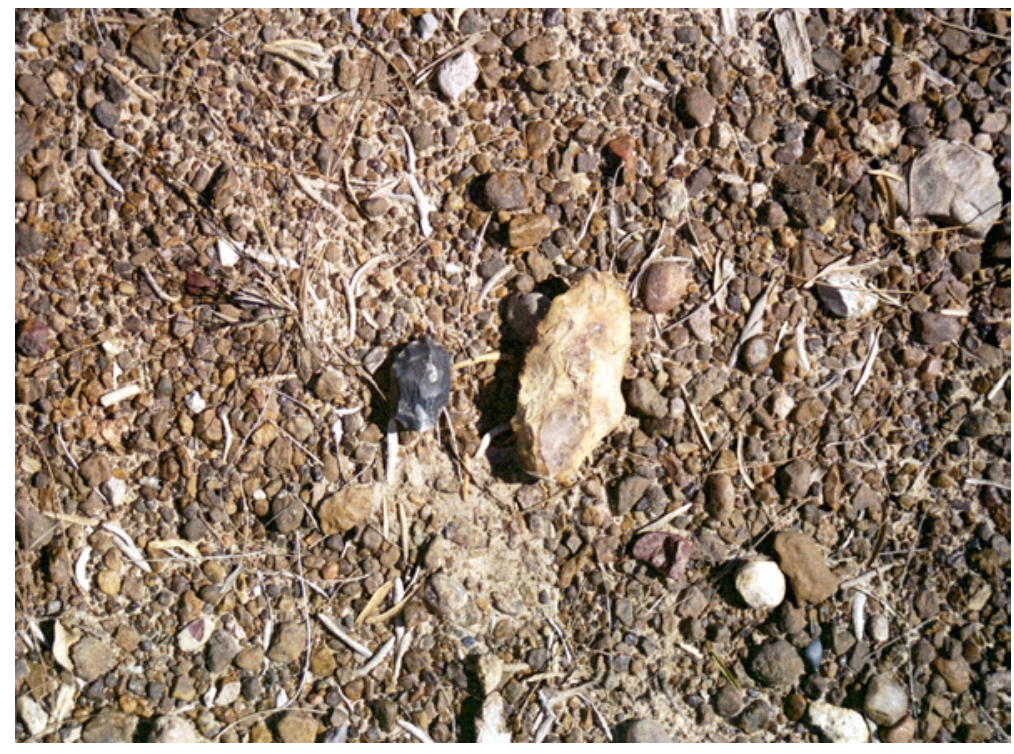

Figure 5-20. A uniface and one of the bifaces found on the surface at $41 \mathrm{BP} 670$.

island in the middle of an intermittent drainage (Figures 5-21 through 5-24). Ranging from 450-462 $\mathrm{ft}$ in elevation, it is covered with hickory, elm, oak, pecan, and cedar trees, with shrubs and sparse grasses as understory. The unnamed drainage along its western edge is deeply incised, with $5 \mathrm{~m}$ cutbank exposures in some areas. Although intermittently flowing, the drainage has numerous catch pools in its clay and sandstone bedrock bottom. Although the Axtell fine sandy loam (AfC2) is sometimes eroded along the creek's edge where red clay is occasionally exposed, deep Patilo complex soils $(\mathrm{PaE})$ otherwise cover the sideslope and ridge. Disturbances observed on the surface include some treefall impressions and an occasional badgersize burrow.

\section{Levels of Work and Results}

We discovered this site during systematic excavation of shovel tests on transects. Shovel tests were placed $30 \mathrm{~m}$ apart along the drainage, and expanded to between 40-60 m apart as we went up the sideslope away from the drainage. Artifacts were initially found in Transect Shovel Tests S4, S5, and $\mathrm{U} 2$ before an additional 28 shovel tests were placed around the site to define its boundaries and vertical integrity. For management purposes we designated the two artifact concentration areas on this site as Area A and Area B.

A third distinct part of the site lies on an "island" or relict portion of the sideslope, isolated when the drainage course shifted (see Figure 5-23). However, excavation of shovel tests on the island (Shovel Tests 26-28) revealed one flake and one tiny piece of fire-cracked rock within very coarse sands mixed with gravels, suggesting that any cultural deposits on the island are in a secondary, alluvial deposit.

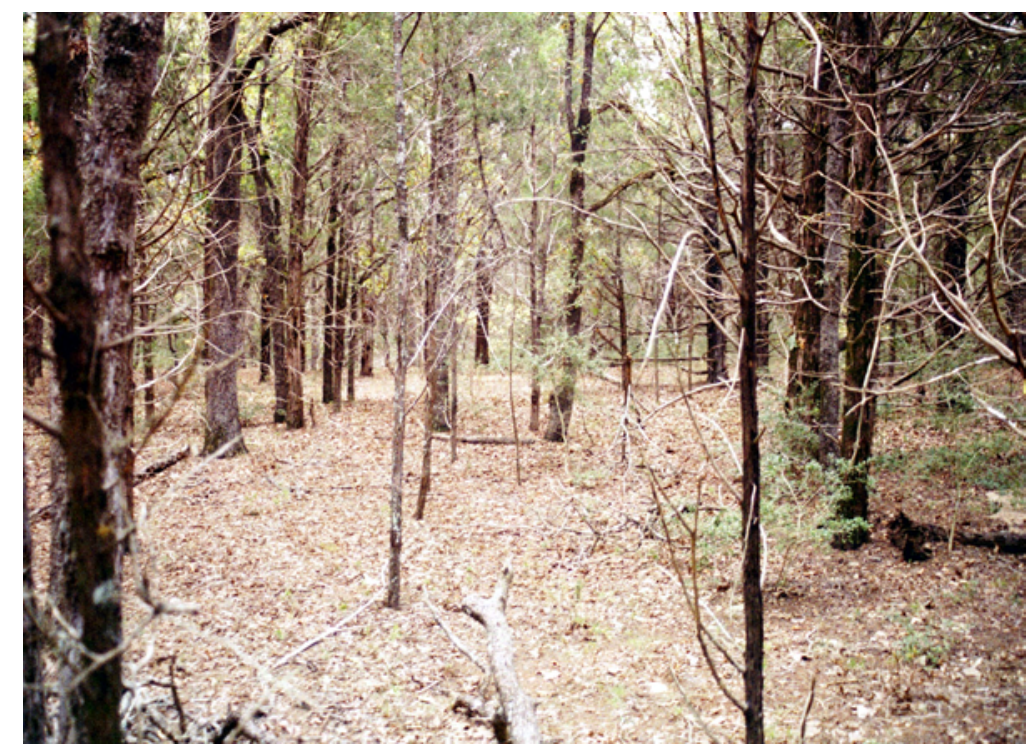

Figure 5-21. 41BP671 is a large open campsite buried in this heavily wooded area; facing east. 
Table 5-10 provides the results of shovel tests. The only possible prehistoric artifacts observed on the entire site were fire-cracked rock in Area B. However, in Area A two small bone fragments were recovered from between $30-40 \mathrm{~cm}$ (Shovel Test 2) and 40-50 cm (Shovel Test 5). Somewhat problematic in Area A is the recovery of crushed gravel between 40-50 $\mathrm{cm}$ in Shovel Test 6 . This may be

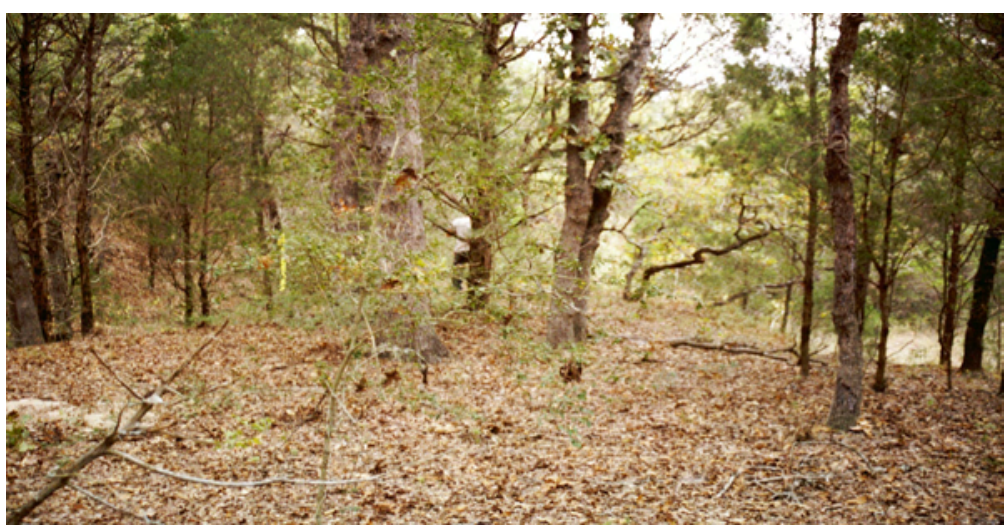

Figure 5-23. Shovel tests on "island" formed when stream shifted at 41BP671; facing northwest. due to rodent disturbance or a small-scale fluvial feature otherwise not visible in the homogeneous sands. The continuum of charcoal found in Shovel Tests 9 and 16 may represent root burns.

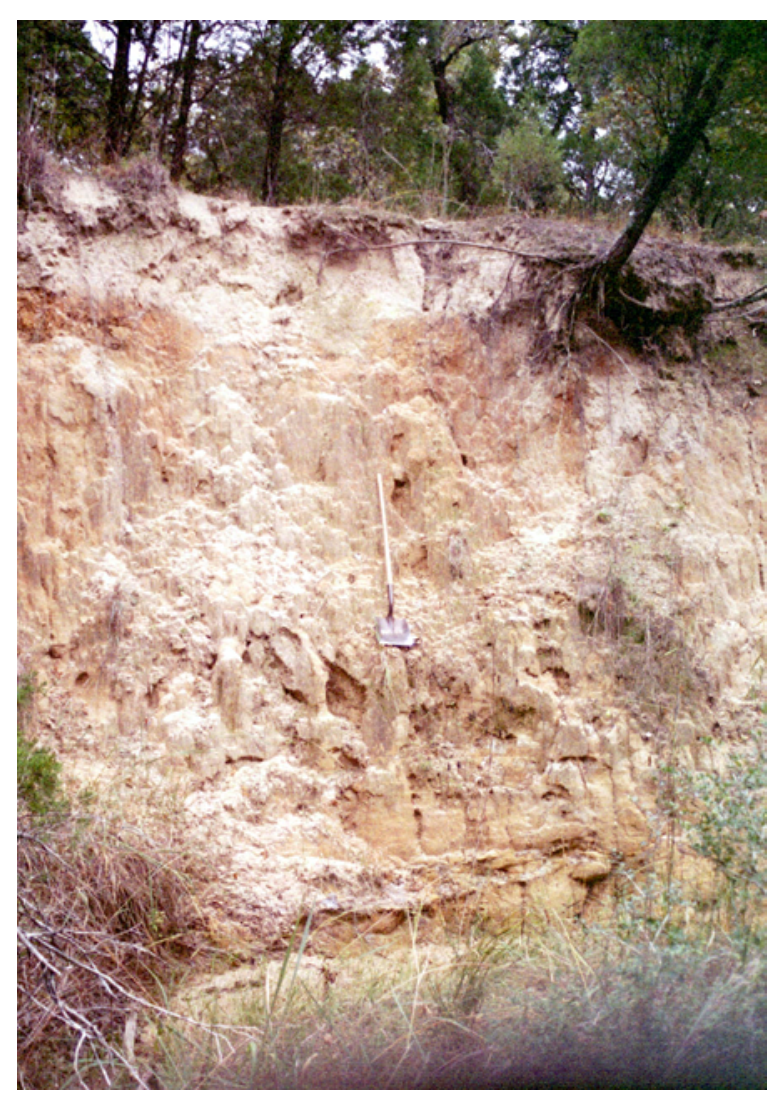

Figure 5-22. Drainage cutbank adjacent to 41BP671; facing southeast.
In Area B, we recovered larger fire-cracked rock pieces from Shovel Tests 14 and S5 between $70-80 \mathrm{~cm}$ below the surface. The fragment in Shovel Test 14 is actually broken into three pieces, and refitted. These two shovel tests are $2.5 \mathrm{~m}$ apart suggesting a possibly intact hearth in the immediate area.

FIGURE 5-24. REDACTED

Figure 5-24. Site map,41BP671. 
Table 5-10. Results of shovel tests at 41BP671.

\begin{tabular}{|c|c|c|c|c|c|c|c|c|c|c|c|c|c|c|c|c|c|c|c|}
\hline Area & A & A & A & A & A & A & A & A & A & B & B & B & B & B & B & B & B & B & B \\
\hline Depth & ST U2 & ST1 & ST2 & ST5 & $\underline{\text { ST6 }}$ & $\underline{\mathrm{ST7}}$ & ST 9 & ST 10 & ST 12 & ST S4 & ST S5 & ST 14 & ST16 & ST17 & ST18 & ST 20 & ST 22 & ST 26 & ST 28 \\
\hline $0-10$ & & & & & & & $\mathrm{Ch}$ & & $B$ & & & fcr & & & & & & & \\
\hline $10-20$ & & & $E F$ & & & & $\mathrm{Ch}$ & & & & & & $f c r$ & & & $s$ & & & \\
\hline $20-30$ & IF & & $\mathrm{Ch}$ & & & & $\mathrm{Ch}$ & & & $F C R$ & & & $C h$ & & & & & & \\
\hline $30-40$ & & & & Bone & & & $\mathrm{Ch}$ & $S$ & & Clay & & & $C h$ & & & & & & $f c r$ \\
\hline $40-50$ & & & Bone & & CG & $E F ; S ; f c r ; C h$ & $\mathrm{Ch}$ & & & & & & $\mathrm{fcr} ; \mathrm{Ch}$ & $s$ & & & & & \\
\hline $50-60$ & & & & & & & $\mathrm{Ch}$ & & Ch & & & & $\mathrm{Ch}$ & & & & & $s$ & Clay \\
\hline $60-70$ & & & & for & & & $\mathrm{Ch}$ & & & & & for & $\mathrm{Ch}$ & & & & $s$ & & \\
\hline $70-80$ & & & & & $F C R$ & & $\mathrm{Ch}$ & & for & & $F C R$ & ${ }^{*} F C R ; f c r$ & $\mathrm{Ch}$ & & IF & & Clay & Clay & \\
\hline $80-90$ & & $S$ & & & & $\mathrm{Ch}$ & $\mathrm{Ch}$ & & & & & & $H S$ & Clay & $f c r$ & & & & \\
\hline $90-100$ & & & & & & & $\mathrm{Ch}$ & & & & & & $2 \mathrm{fcr}$ & & & & & & \\
\hline $100-110$ & Sand & Sand & Sand & FCR; fcr & Sand & Sand & Sand & Sand & Sand & & Sand & Sand & & & Sand & Sand & & & \\
\hline 110-120 & & & & & & & & & & & & & Sand & & & & & & \\
\hline $120-130$ & & & & Sand & & & & & & & & & & & & & & & \\
\hline \multicolumn{20}{|l|}{ 130-140 } \\
\hline & & & & & & & & & & & & \multicolumn{5}{|c|}{ * Large FCR in ST 14 is articulated in 3 pieces. } & & & \\
\hline & & & & & & & & & & & & & & & & & & & \\
\hline \multicolumn{19}{|c|}{ Key: EF - Exterior Flake; IF - Interior Flake; S - Shatter; B - Biface; FCR - Fire-Cracked Rock >1"; fcr - fire-cracked rock <1"; Ch - Charcoal; CG - Crushed Gravel } & \\
\hline & & & & - unexcav & & & & & & & & & & & & & & & \\
\hline
\end{tabular}

\section{Conclusions/Recommendations}

The results of shovel test excavations suggest that an intact buried hearth might exist in the immediate area of Shovel Tests 14 and S5 in Area B. Additionally, two pieces of bone were found between $30-50 \mathrm{~cm}$ in Area A. The presence of preserved faunal remains is rare at Camp Swift and other sandy mantle sites in the region. We therefore recommend a minimum of four backhoe trenches be excavated within those areas of concentration to further assess the integrity of this site. The trenches should be carefully excavated in 3 to $5 \mathrm{~cm}$ levels in a scraping fashion to expose possible features, or in this case, preserved faunal material. If discovered, features or exposed faunal material should then be excavated by hand.

\section{BP672}

\section{Description}

41BP672 is an open campsite covering approximately $6,836 \mathrm{~m}^{2}$ of a sloping, upper terrace of Big Sandy Creek (Figures 5-25 and 5-26). Elevation at the site ranges from 430-440 ft above mean sea level. The terrace is made up of Patillo complex soils (PaE). According to Mr. Abner Scott (per- sonal communication, January 16, 2002), this area was cultivated by C. R. "Nick" Branton, a previous landowner. It is now overgrown with tall grasses and wild grapevines. It also lies at the periphery of an upslope area previously approved as a "Dig Area" for mechanical equipment. Excavation of shovel tests in 1995 by AGTX personnel in the Dig Area produced no artifacts (Wormser and Leshley 1995).

\section{Levels of Work and Results}

Initial surface assessment of this site noted the southern portion had been heavily disturbed by mechanical earth-moving equipment. Numerous push piles, apparent bladed short roads and trails, an earthen mound, and exposed clay areas are prevalent on the upslope and along its southern edge. No artifacts were observed on the surface, but the site was discovered during systematic excavation of shovel tests in $30 \mathrm{~m}$ intervals along a high site probability terrace. Table 5-11 provides the results of shovel tests on and around the site. Included within the table are cryptic notes taken during excavation of shovel tests and extracted from the shovel test forms. Note that the disturbed area 
drawn on Figure 5-26, the site map, is based upon observations of mixed sediments. More obvious disturbances such as push piles and graded areas exist farther south and upslope.

\section{Conclusions/Recommendations}

The evidence produced from shovel tests indicates that much of the site has been disturbed. This is FIGURE 5-26. REDACTED evident in Shovel Tests H2 and K1. However intact sediments and soils, along with artifacts, were encountered in Shovel Tests G1, G2, I2, and I3 in the lower portion of the terrace, closer to Big Sandy Creek (see Table 5-11). We recommend four backhoe trenches be excavated along the lower portion of the terrace to further evaluate the integrity Figure 5-26. Site map, 41BP672. of this site adjacent to the creek. The trenches should be carefully excavated in $\sim 5$ cm levels in a scraping fashion so to expose possible features. Once exposed, the features should be

excavated by hand.

\section{Section II: Historic Components}

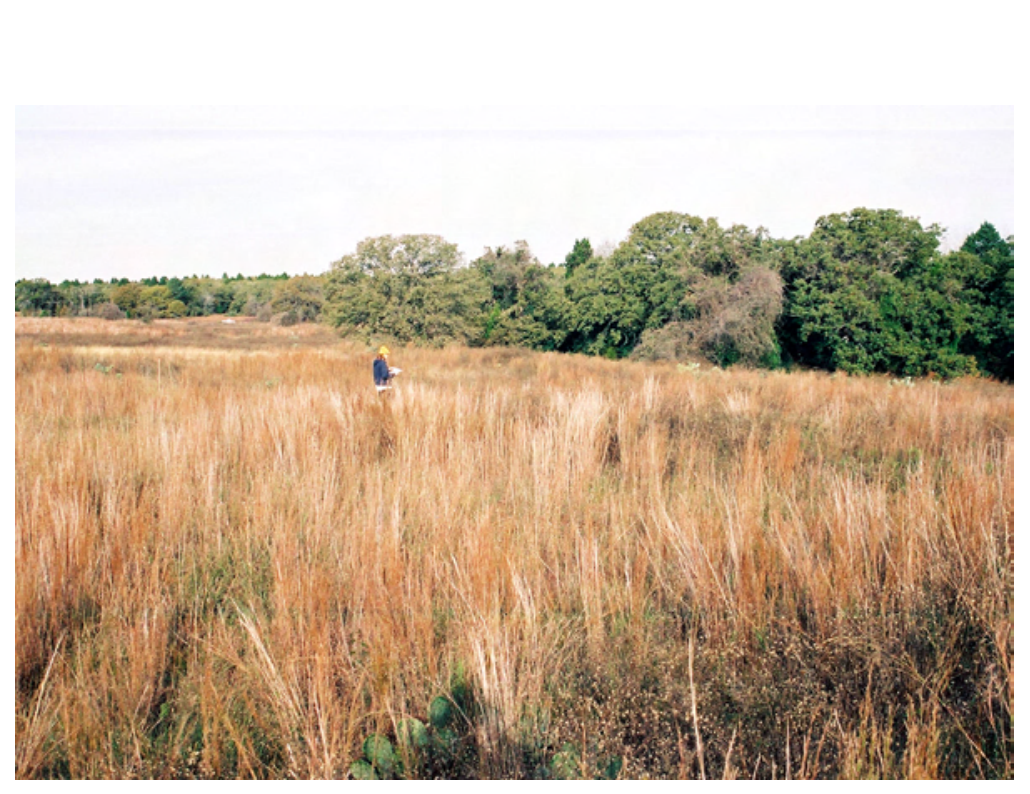

\section{$41 B P 663$}

\section{Description}

41BP663 (Figures 5-27 and $5-28$ ) is a farmstead with no remaining structures. Based upon shovel tests and an ephemeral surface scatter, the site encompasses 2,079 $\mathrm{m}^{2}$. A rectangular mound ca. 10-15 cm high in thick brush is the probable location of a bulldozed house. As with virtually all pre-WWII structures at Camp

Figure 5-25. 41BP672 is situated on an upper terrace near Big Sandy Creek; facing north. 


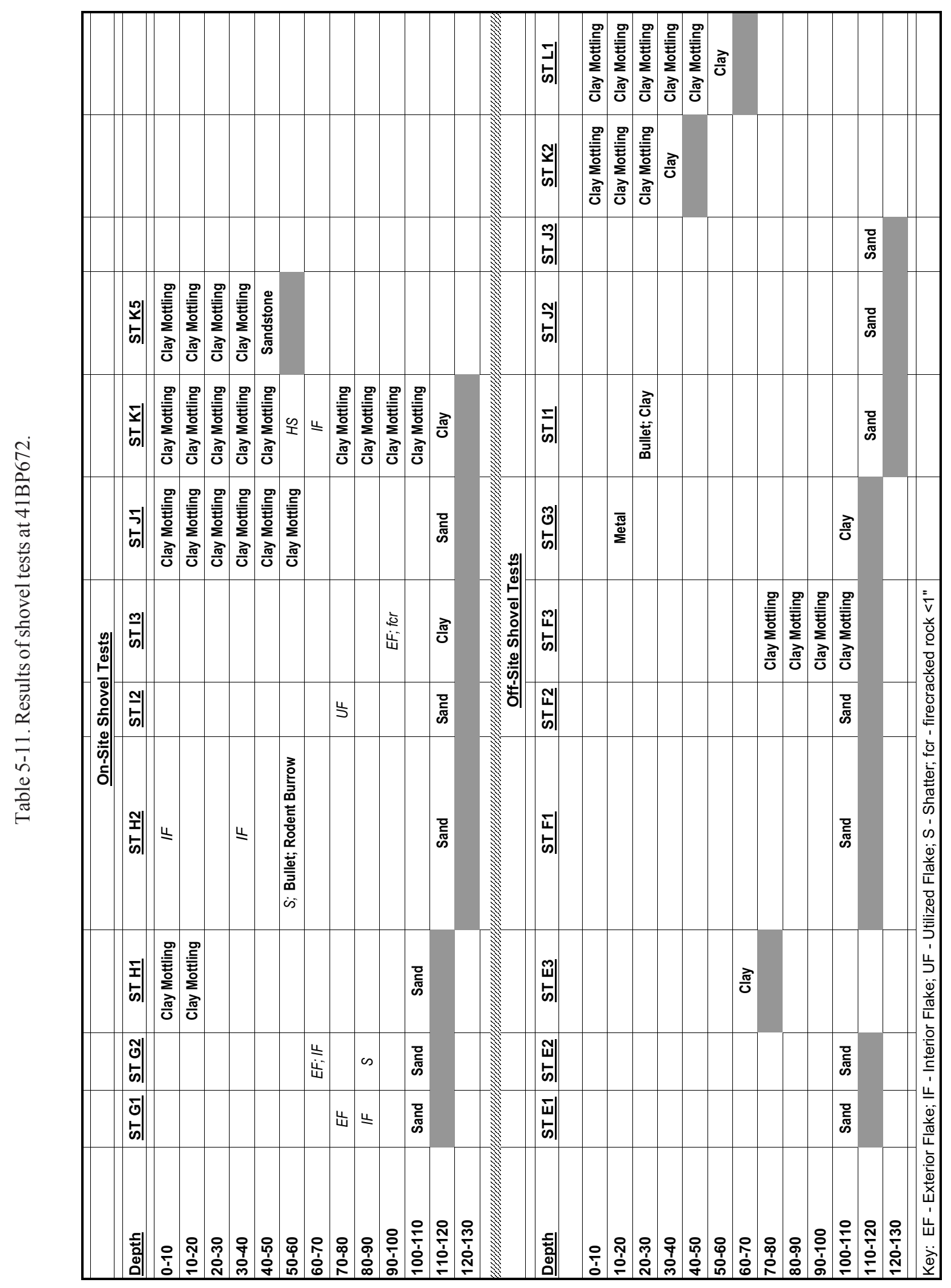




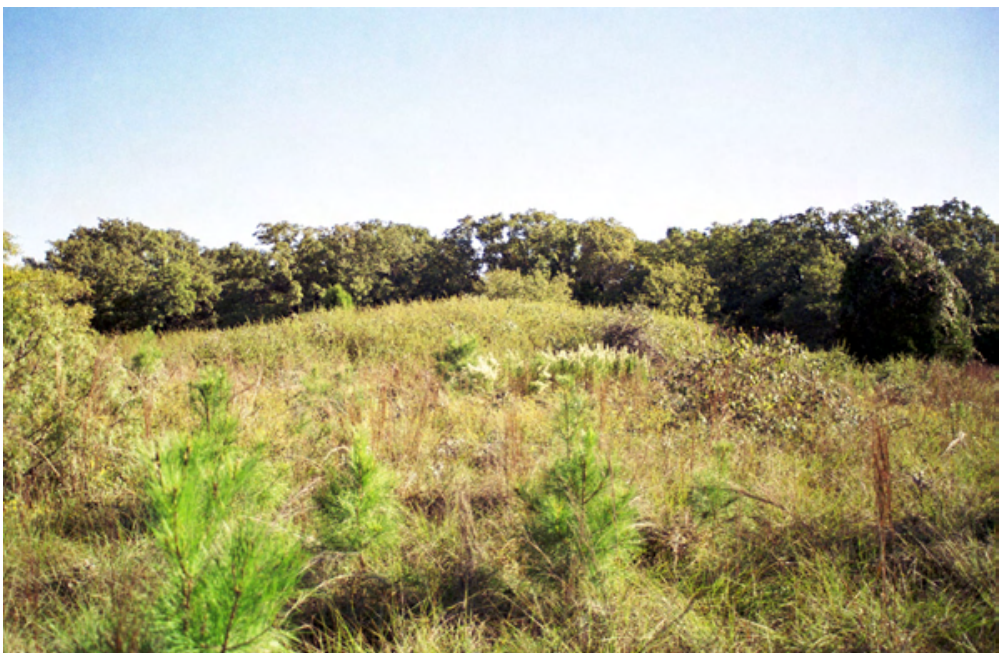

Figure 5-27. Site 41BP663; the bulldozed house that may have belonged to the Vonkochneritz family was in the middle of this thicket; facing northeast.

Swift, houses, any outbuildings, pens, and corrals were bulldozed during Camp Swift's development in World War II. The house was situated on a flat upland area, $15 \mathrm{~m}$ south of Scott Falls Road at an elevation of $472-474 \mathrm{ft}$.

Tabor fine sandy loam (TfB) covers the area and supports waist-high grasses and weeds, with scattered small cedar and pine trees. As farmland, Tabor loam would have been good for growing grasses and legumes, and fair for grain and seed crops. Otherwise, cattle would do well on Tabor soils rangeland (Baker 1979). The sandy soil is generally shallow and shovel tests produced mottled orange clay underlying the historic artifacts, indicating that the area has been significantly disturbed. The nearest fresh water source is Spring Branch Creek, approximately 150 $\mathrm{m}$ to the northwest. Surface visibility was less than 5 percent at the time of the September 2003 visit to the site.

Levels of Work and Results

A dense thicket of brush located in an otherwise open, grassy field seemed out of context, perhaps representing a highly disturbed area. In addition, a 1936 county highway map indicated a structure in the general area (copy on file, CAS). Therefore, in addition to Transect Shovel Test J1, six shovel tests were placed around the edge of the thicket, and one in the middle of the thicket (see Figure 5-28). The results of shovel test excavations are given in Table 5-12.

Limited archival research into this property
FIGURE 5-28. REDACTED

Figure 5-28. Site map,41BP663. 
Table 5-12. Results of shovel tests at 41BP663.

\begin{tabular}{|c|c|c|c|c|c|c|c|c|}
\hline Depth $(\mathrm{cm})$ & $\underline{\text { ST J1 }}$ & sT 1 & $\underline{\text { ST } 2}$ & $\underline{\mathrm{ST}} 3$ & $\underline{\text { ST } 4}$ & $\underline{\text { ST5 }}$ & $\underline{\text { ST } 6}$ & $\underline{\text { st } 7}$ \\
\hline $0-10$ & & & & & Metal Snap Clear Glass & & & Clear Glass; Amber Glass; Square Nail; Stoneware \\
\hline $10-20$ & Heat Spall & & & & & & Clear Glass; Light Green Glass & 3 Square Nails; 2 Whiteware Sherds \\
\hline $20-30$ & & & & Square Nail; Deer Tooth & & & & Unidentifiable Metal Fragments \\
\hline $30-40$ & & & Clay Mottling & Angular Ironite & & & & 2 Square Nails \\
\hline $40-50$ & Orange Clay & & & Light Green Glass & Small Fire-Cracked Rock & Clay Mottling & Clear Glass & Clay Mottling \\
\hline $50-60$ & & Orange Clay & Orange Clay & Clay Mottling & Clay Mottling & Clay Mottling & & Orange Clay \\
\hline $60-70$ & & & & Orange Clay & & Orange Clay & Clay Mottling & \\
\hline $70-80$ & & & & & Orange Clay & & Clay Mottling & \\
\hline $80-90$ & & & & & & & Orange Clay & \\
\hline & & & & & & & & \\
\hline
\end{tabular}

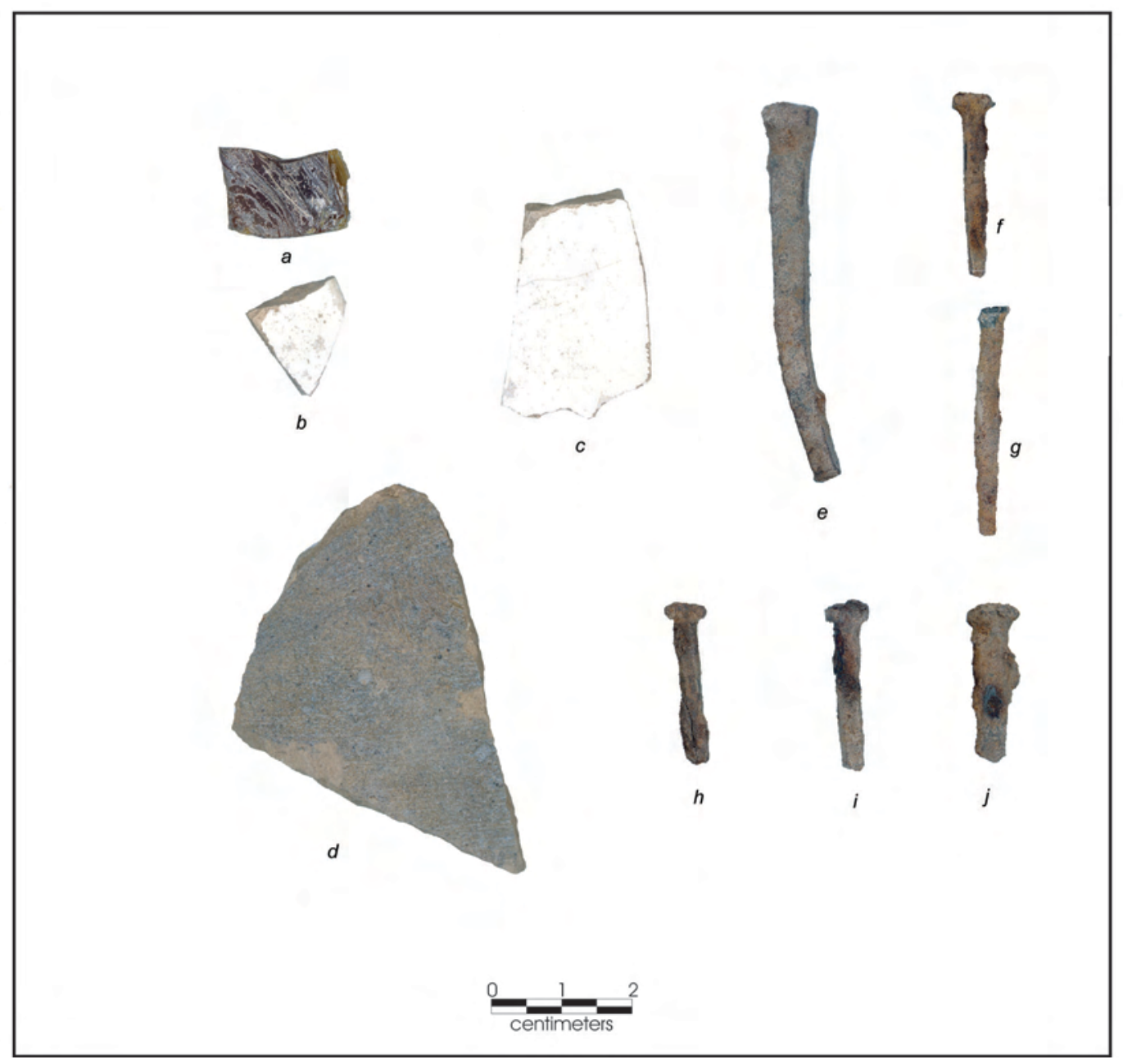

Figure 5-29. Selected artifacts collected from shovel tests at 41BP663; a: amber glass, b \& c: whiteware, d: stoneware, e-j: square nails. 
revealed that in 1929, S. Vonkochneritz owned the 100-acre parcel surrounding the house site (Bastrop County Map 2003), however a search of the Handbook of Texas, Bastrop County archives and a internetsearch did not provide additional information.

Ideally, the artifacts found around the house should corroborate the approximated time period during which the house was constructed and occupied. Selected items discussed below are shown in Figure 5-29. All seven nails recovered were square. In the early 1900 s round nails became common and mass- produced. Although square nails were used in the early 1800 s and are still in use today, their most common period of use was before 1900. In undisturbed contexts from well-documented structures, data on cut, square, and round nails can be useful (e.g., Jurney 1988). However, given the disturbed context of this site, we can only say that given the ubiquity of square nails, and the absence of round nails, it suggests that the house was constructed before 1900 .

Two pieces of undecorated whiteware were found in Shovel Test 7, and two sherds were found in a gully approximately $20 \mathrm{~m}$ to the southeast of the mound (see Figure 5-29). Whiteware is a highlyfired refined clay with a vitreous surface. Unfortunately for archaeologists, the use of whiteware in Texas spans a considerable time period. Undecorated whiteware was commonly imported to America from Britain during the 1800 s, but the demand for undecorated wares increased significantly in America by 1860 . This type became a common tableware for middle class families in this portion of Texas after the 1860 s, replacing pewter and wooden wares (Fox et al. 1989:45), however these whitewares are still being produced today (Miller 1991, 1993). Therefore, its presence at the Vonkachneritz site broadly places the potential occupation of the site from about 1860 through today.

One stoneware sherd was found in Shovel Test 7. Stoneware is a utilitarian ware and was commonly used in Texas kitchens and dairies from 1860 through 1950 (Greer 1981:13-26). This particular specimen has an unglazed interior, with a grey slip covering its exterior. Generally, vessels were unglazed on the interior before about 1850 in the United States (Greer 1981). The earliest pottery kilns in Bastrop County began operation in the mid1850s; those nearest to 41BP663 were in McDade, and they began operating in the 1890s (Greer nd; Moore 1977:176-177), producing a variety of wares for residents of Bastrop County. As such, it is feasible that the stoneware piece recovered from 41BP663 dates to around 1850, but more feasibly probably dates to just before the turn of the century.

Six bottle glass sherds were found; two are light green, one is clear frosted, two are clear, and the sixth is amber. The two clear glass sherds likely date to no earlier than 1930. Although somewhat discolored, the opalescent, rainbow effect on these pieces is simply a silicate skeleton left behind after moisture has leached out some of the lime and soda in the glass. They do not show signs of amethyst or amber discoloration caused by sunlight exposure to clear glass containing either manganese or selenium, used between 1880 and 1930 (Munsey 1970).

One of the light green glass sherds has embossed lettering on it suggesting it could date to the early 1800 s. Both pieces are thin, well made, and exhibit only slight patination. No other diagnostic traits are shown on either of the two pieces; however, they are not unlike bottle glass specimens dating from the turn of the century to modern times. The clear glass sherd with a frosted surface also appears to have been manufactured after 1930. 
Although the frosting technique was used in the early 1800 s, and is still used today, the purity and clarity of this specimen indicate a post-ca.1930 date.

The dark amber glass sherd has a very heavily patinated or "sickened" surface suggesting it is older than the other five glass sherds. Its amber color is apparently due to the degradation of selenium, an additive to make clear glass between 1915 and 1930 (Munsey 1970).

A single suspender button or snap from a pair of work overalls was found in Shovel Test 4. It has a heavily rusted ferrous facing with a cuprous backing. Overalls were and still are very common farm work clothes. By the mid-1800s, they were the first mass-produced pieces of clothing (Overalls 2003). In sum, the snap we found could date from ca. 1850 through modern times.

\section{Conclusions/Recommendations}

In general, the ages of the artifacts such as the square nails, the metal snap, and the stoneware sherd, suggest a possible mid-nineteenth century occupation, while the glass suggests an occupation through post1930. Nevertheless, the site has been bulldozed, there are no structural remains above ground, and we found no other evidence of significant historical importance. A search of the Handbook of Texas, Bastrop County archives and a global internet search failed to provide information of any significance associated with the name of Vonkochneritz, or similarly spelled names. As such, the site as ineligible for nomination to the NRHP, and no further work is recommended.

\section{BP666}

\section{Description}

41BP666 (see Figures 5-30 and 5-31) contains the remains of a twentieth century farmstead on a gentle sideslope near Spring Branch, a constantly flowing, spring-fed stream. The only intact remains discovered at this site are the bricks forming the chimney base. Otherwise, scattered artifacts are found strewn across the site or in push piles. Secondary growth trees and brush mark the previously cleared area, surrounded by mature elm, oak, and cedar trees. As farmland, the Patillo complex soils $(\mathrm{PaE})$ would have been good for growing grasses and legumes, and fair for grain and seed crops. Otherwise, cattle would do well on Patillo soils rangeland (Baker 1979).

\section{Levels of Work and Results}

During an interview with previous Camp Swift landowner, Abner Scott on January 16, 2002, Mr. Scott informed us that a man named Noel Branton

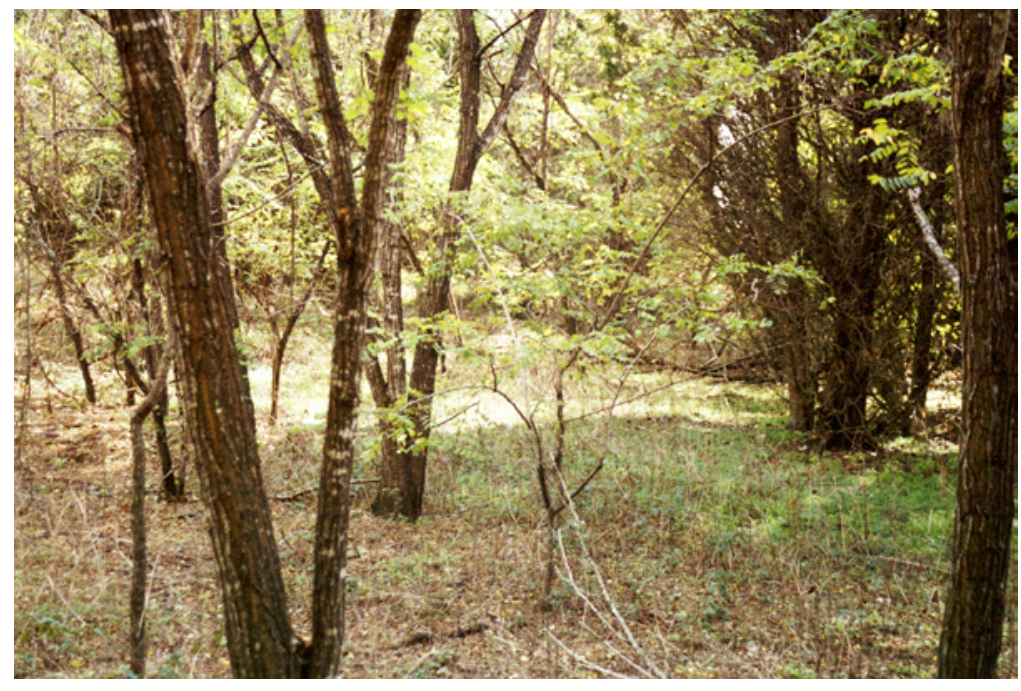

Figure 5-30. This was the site of Noel Branton's house; facing southeast at41BP666. 
FIGURE 5-31. REDACTED

Figure 5-31. Map of the historic component at 41BP666.
O. Buckley, December 26, 1926

(Bastrop County Database 2003;

Bastrop County Marriage Index

2003). Exactly when the house was constructed is unknown, although a 1929 landowner map of Bastrop County indicates "N. Branton" owned 100 acres at this location(Bastrop County Map 2003). By 1938, Noel Branton's name appeared on a Petit Jury list in Elgin, Texas (Texas Genealogy 2003). Noel died in Bastrop on April 1, 1989 (Bastrop County Database 2003).

According to Mr. Scott, when Noel Branton moved out of the house and into town, the house was rented by Mr. Scott's mother-in-law and father-in-law, who raised their children there before the military took the land. While living in the house, Mr. Scott's in-laws paid the rent by farming for shares or one-half of the crops they raised. lived in a house in this general area. The house was built for Noel by his father and mother, Cornelius Robert (C. R.) "Nick” Branton and May (Scott) Branton. C. R. "Nick" Branton was Abner Scott uncle, and thus, Abner Scott and Noel Branton were cousins.

According to Bastrop County Records, C. R. "Nick" Branton married May Scott on October 10, 1894. Their son, Noel Ernest Branton was born on September 25, 1895 (Bastrop County Births 2003). In 1917, at about age 22, he registered for the Selective Draft in Elgin, and later married Myrtle
Documentation of the site included a surface inventory, noting probable locations of the house, outbuilding, pens, old fence posts, gates, and old roads. An old road ran southeast to the remains of an old gate, with a railroad tie across a gully to provide traction. The road ran down into the creek bottom before its path became obscured. Its direction heads toward C. R. "Nick" Branton's house at $41 \mathrm{BP} 397$.

Ideally, the artifacts, construction items, and method of construction found at a site should corroborate the approximated time period during 
which the house was constructed and occupied; in this case, based upon the above discussion, about 1920 through about 1942.

Although the dullyellow, modern looking bricks forming the base of the chimney had no maker's mark, they were extremely well made, hard, and high-fired, with undamaged, sharp corners. They were mortared together with strong, fine, unrotten mortar. Because of other bricks found scattered on the surface, at first we

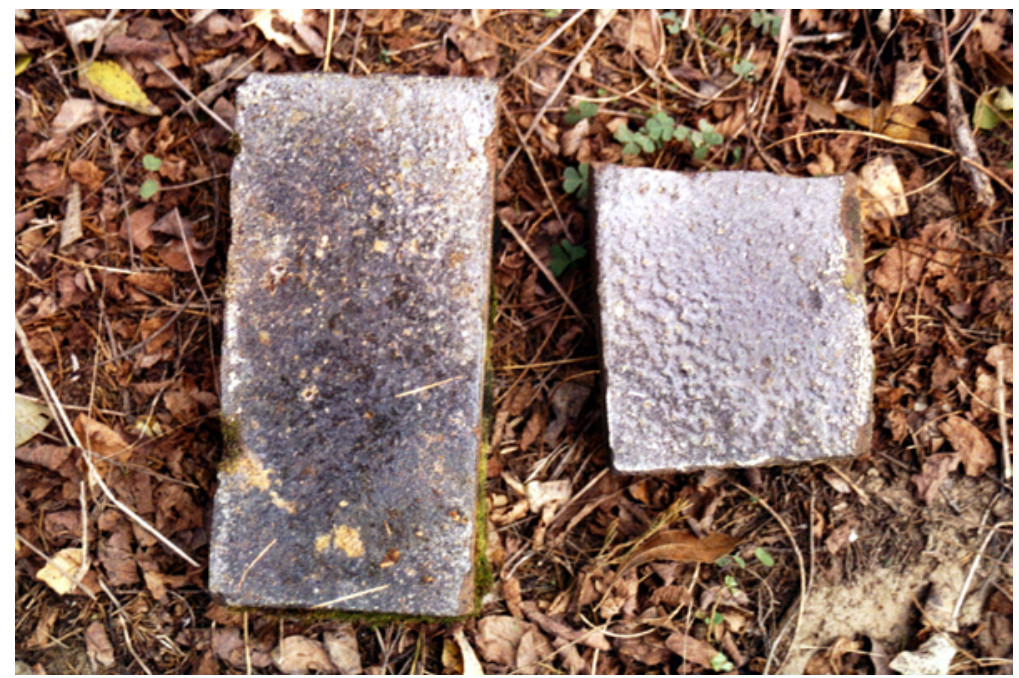

Figure 5-33. Gray, salt glazed, red bricks found on the surface at 41BP666, presumably from a pottery kiln. suspected they were perhaps part of a kiln, but after uncovering them, measuring their outline $(190 \mathrm{~cm} \mathrm{x}$ $190 \mathrm{~cm}$ ), and examining burned versus unburned faces, it was concluded that they formed the chimney base (Figure 5-32).

Quite contrary to the fine made, fire-darkened, yellow bricks that make up the chimney are three red, crude, and poorly-fired bricks with thick, dark gray glaze on both faces (Figure 5-33). These

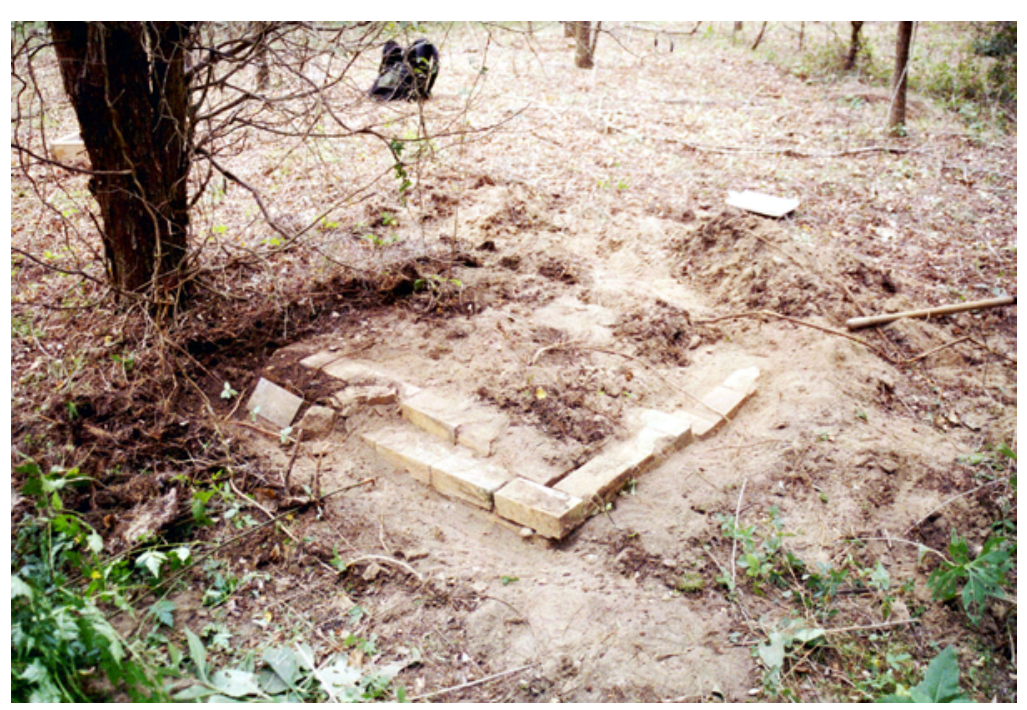

Figure 5-32. Chimney base at Noel Branton's house, 41BP666; facing southeast. unlabeled red brick fragments are crumbly with large clasts, rounded edges. Making crude bricks was not uncommon among early Anglo settlers, beginning in the $1820 \mathrm{~s}$, and continued through the first quarter of the twentieth century, before brickmaking becamemoreindustrialized(Steinbomer 1982:33-70). These specimens are not unlike those made during the last quarter of the nineteenth century in local kilns.

However, these three bricks appear to be actual bricks from the kiln rather than bricks fired within a kiln for use in other construction because 1) they are glazed, and 2) they are glazed on two sides. The glazing on opposite faces suggest that they were not part of the wall of a kiln, but more likely part of a draft opening near the ceiling of a kiln. Construction bricks are almost never glazed unless for decorative purposes, and glazing of this thickness results from often repeated firings in kilns where pottery vessels are purposely salt- 
glazed or alkaline-glazed.

These are undoubtedly kiln bricks very much like those found at other pottery kiln sites dating from the late 1800 s through the early 1900 s, such as 41WN59, the Suttles Kiln in Wilson County; and the Wilson pottery kilns in Guadalupe County (David Nickels, personal observation, 2002) and as seen on many other pottery and/or brick kilns of the same era in Texas (e.g., Greer n.d., 1981).

The glazing on these specimens appears to be salt glaze. Although one of the earliest techniques for glazing pottery in North America, it was likely introduced into Texas by migrants from the southern United States by 1850. Because of expense and a shortage of salt during the Civil War, it was not a common technique used by rural potters until around the 1870s and 1880s (Greer 1981). Although some local potters continued to use the salt glaze method well into the first quarter of the twentieth century, for the most part, salt glazing was replaced by either Bristol glaze and/or Albany slip. The salt glaze is fixed to the vessel by throwing common salt into a heavily fired kiln. At the right temperature salt will vaporize, and when combined with the silica on clay pot surfaces, forms sodium silicate, or salt glaze. Although the ideal surface is smooth, in old wood fired brick kilns the surface of the glaze very much resembles that of an orange peel, with many small bumps. The color is merely a reflection of the amount of iron in the clay vessel (Greer 1981).

A broken gallon-sized stoneware crock was found on the surface (Figure 5-34).
Its interior is fully covered with a brown Albany slip; its exterior upperportion is also Albany slipped, but its lower portion is coated with off-white Bristol glaze. This combination of Albany slip on the shoulder, mouth and interior of vessels, with a Bristol glaze body was most commonly produced between 1880 and 1920 (Greer 1981:212).

A whole, clear glass condiment bottle (Figure 5-35) was also found on the surface, partially covered by leaves. The glass is very clear, with no hue or evidence of sickening, indicating it was made after 1930, and has had little exposure to sunlight. It has two mold seams running all the way up the neck and onto the top of the lip, and an off-centered machine-made valve mark on the bottom, indicating it was made after 1903. It would have been labeled with a paper label which is no longer attached.

However, the distinguishing markings on this bottle reveal its true age. On the bottom is a raised letter "O" inside a square, with the numbers " 3 " on one side of the square, and " 7 " on the other side. The "O" indicates it was manufactured by the

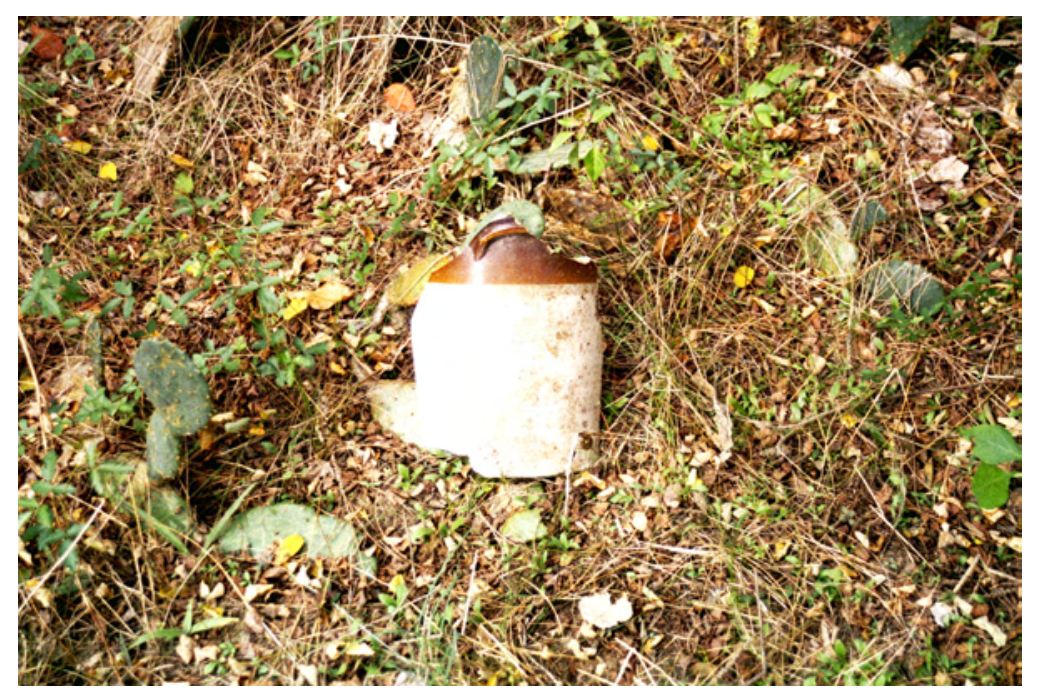

Figure 5-34. Broken, one gallon stoneware crock found on the surface at $41 \mathrm{BP} 666$. 


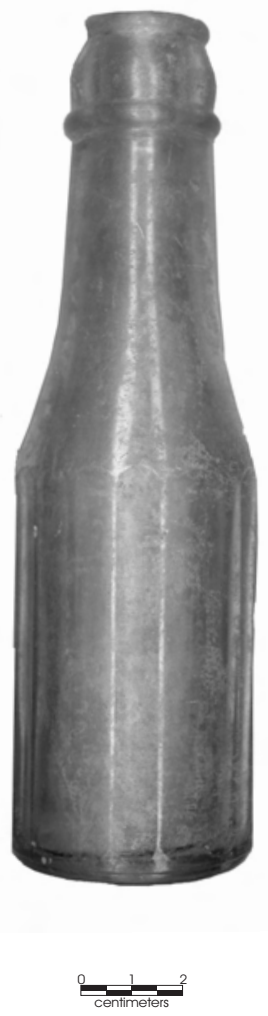

Figure 5-35. This clear glass condiment bottle found on the surface at 41BP666 was produced in either 1917 or 1927 by the Owens Bottle Company.

Owens Bottle Company. In 1909, the company's predecessor began making vinegar, grape juice, and catsup bottles, among others. The Owens Bottle Company was formed from consolidated interests and began using the "O" inside a square as a trademark in Ohio in 1911. The " 3 " indicates that the bottle was manufactured at the Fairmont, West Virginia facility, and the "7" indicates it was produced in either 1917 or 1927 (Toulouse 1971:393397).

Finally, approximately $90 \mathrm{~m}$ southeast of where the house stood is an earthen berm beside a 46 foot long trench. The gradually sloping trench is 5 feet at its deepest. There are no artifacts or construction materials in the trench, but standing on its side and attached to two cedar posts is a wooden door (Figures 5-36 and 5-37). The wood is still in good shape, with mortised edges and modern hardware. The cedar posts also have rusted barbed wire attached to them. Two cinder blocks were lying on the surface just north of the berm, but they could be unrelated to the berm construction. The purpose of construction and use of the berm and trench is unknown. Other items observed on the surface are listed in Table 5-13.

\section{Conclusions/Recommendations}

Based upon archival research and the words of an informant, the house at 41BP666 belonged to Noel Branton was constructed around 1920. Others lived in the house and farmed the area until 1942, when the military acquired the land. Generally, the artifacts and construction material date to this time period. Although the stoneware crock may have been produced earlier, stoneware is very durable, and commonly kept in households for many years after it was produced. Normally, given

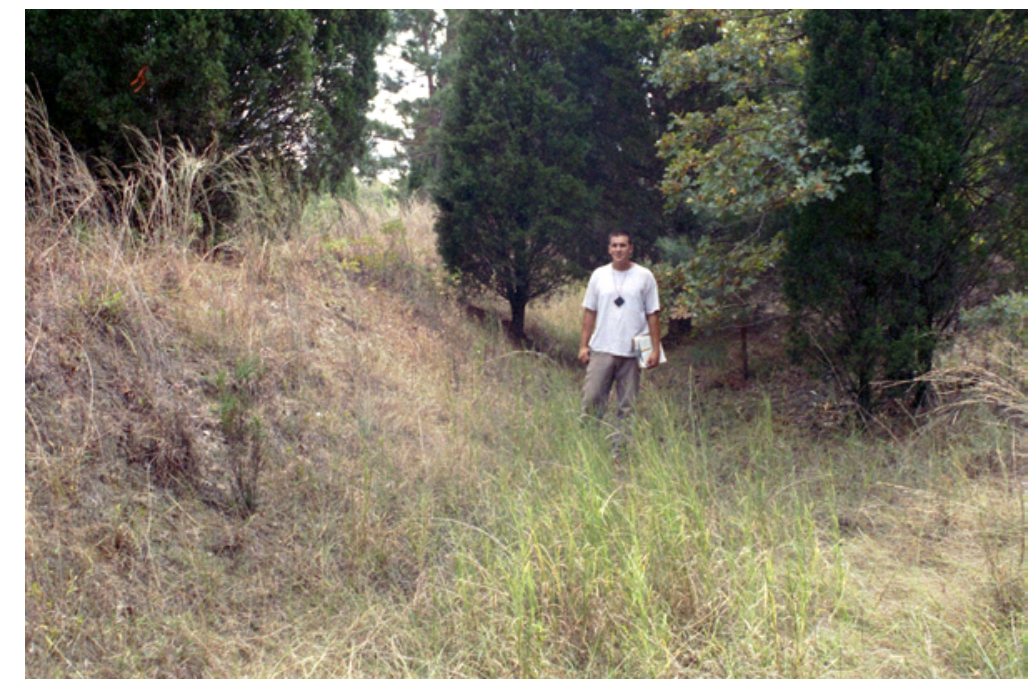

Figure 5-36. 41BP666; Jimmy Barrera in trench beside earthen berm; facing southeast. 


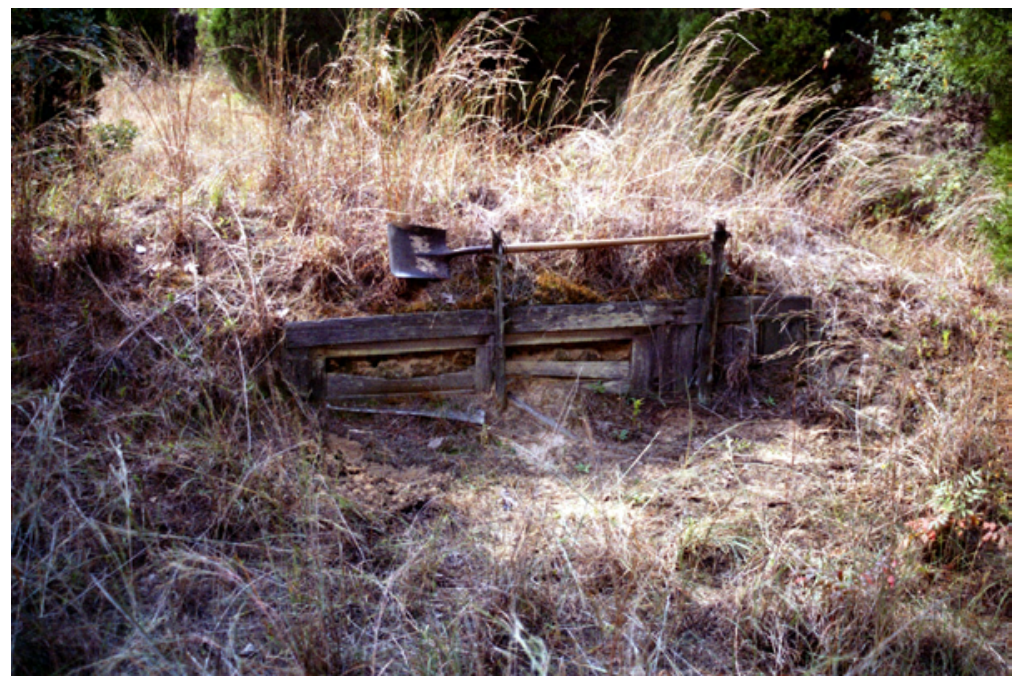

Figure 5-37.41BP666; Earthen berm with wooden door and cedar fence posts; facing southwest.

the poor condition of the house and site in general, it would be recommended ineligible for NRHP.

However, the three glazed, red bricks found on the surface are clearly an anomaly at this site. Their crude manufacture and their salt glazed surfaces suggest they were part of a pottery kiln used between about 1880 and 1920. The earliest pottery kilns in Bastrop County began operation in the mid1850s and only eight are documented in Bastrop County (Greer nd; Moore 1977:176-177). Local kilns were a unique industry, providing necessary goods to rural landowners located far from major trading centers.

If the glazed bricks found at 41BP666 repre-

Table 5-13. Historic items observed on the surface at 41BP666.

\begin{tabular}{|l|l|}
\hline Light green jar glass & Patterned sheet metal siding \\
\hline Clear bottle glass (no hue) & Scattered yellow bricks \\
\hline Cobalt bottle glass (screw top) & Glazed kiln bricks \\
\hline Clear glass condiment bottle & Unidentifiable tin fragments \\
\hline Clear & Fence post with round nail \\
\hline Clear, frosted dinner plate & Cedar fence post \\
\hline stoneware, 1-gallon crock & H-Brace and corner posts \\
\hline Whiteware & Railroad tie corner posts \\
\hline Tin wash tub & Woven wire \\
\hline Enamel coated wash basin & Barbed wire \\
\hline \hline
\end{tabular}




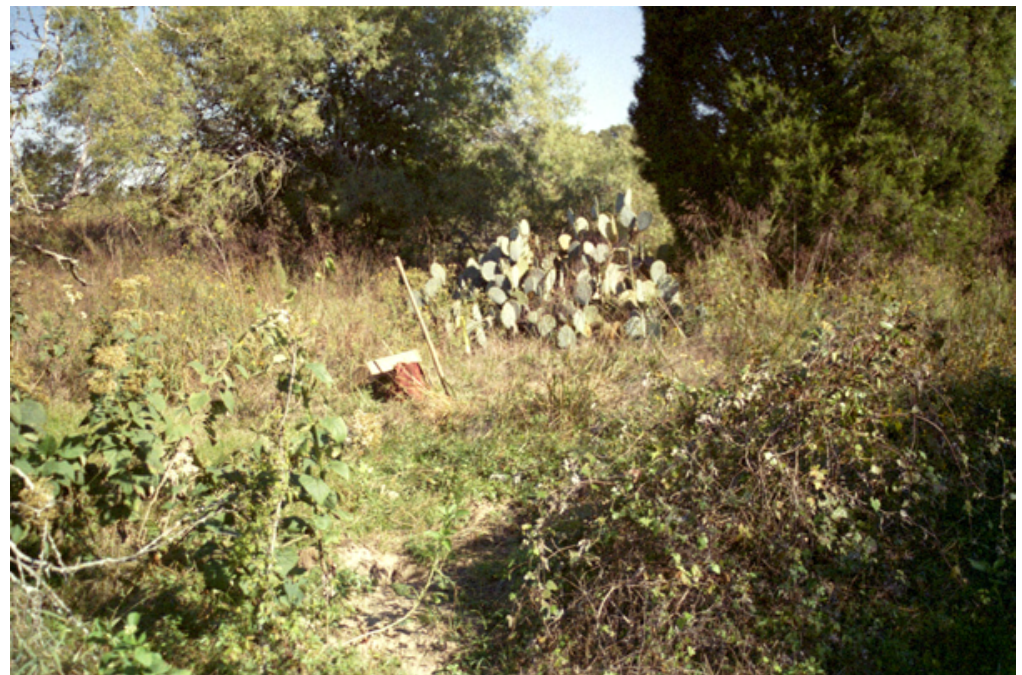

Figure 5-38. 41BP668 lies at the base of a slope, on an old field; facing north. hibited only slight "sickening" or patina, with no amethyst hue or amber discoloration, indicating they probably post-date 1930 (Munsey 1970). The light green and brown glass, medium thick sherds also exhibit little patina, and are both well made, suggesting a date of manufacture probably after the turn of the century. The three undecorated whiteware sherds do not help define the age of this site (see discussion in 41BP667). 40-cm deep trench has been cut along the eastern and southern edges of the site. No structural remains, well, or artifacts were visible on the surface as it was overgrown with vines and brush. Approximately $90 \mathrm{~m}$ to the southeast is a pond formed by an earthern dam at the head of an intermittent drainage.

\section{Levels of Work and Results}

Although a 1936 road map of Bastrop County shows a structure in this general area, the exact location could not be pinpointed. Systematic excavation of shovel tests on $30 \mathrm{~m}$ transects identified cultural materials. Transect Shovel Test I1 yielded a rim portion of a thick, iron pot with a 9-inch $(22.5$ $\mathrm{cm})$ opening, generally straight sides, and possibly a flat bottom. Table 5-14 provides the results of an additional three shovel tests placed on the site.

All 25 clear glass sherds ex-
The two stoneware sherds have Albany slip (or some local variation) on both their interior and exterior, suggesting a probable manufacturing date of between about 1875 and 1900 (Greer 1981:197,

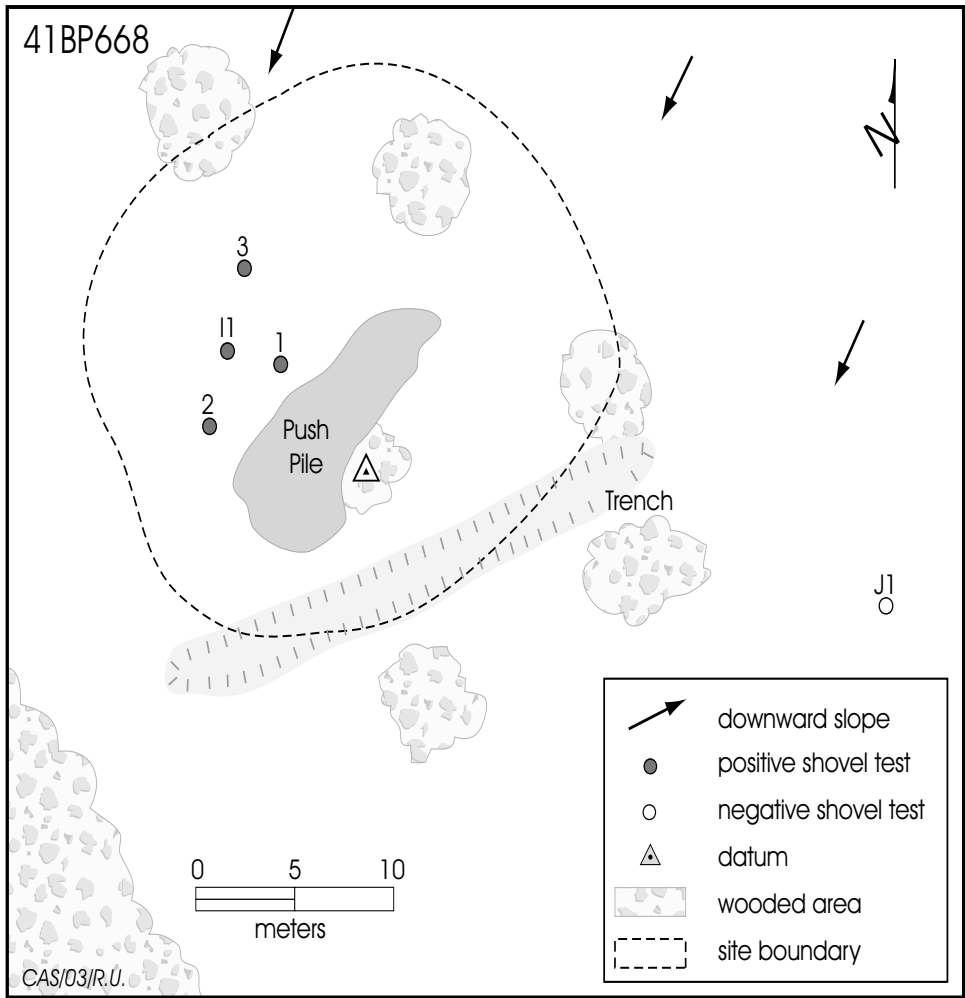

Figure 5-39. Site map, 41BP668 
Table 5-14. Results of Shovel Tests at 41BP668.

\begin{tabular}{|c|c|c|c|c|}
\hline $\begin{array}{c}\text { Shovel Test } \\
11 \\
\end{array}$ & $\begin{array}{c}\quad \underline{0-10 \mathrm{~cm}} \\
\text { Iron Pot Fragment }\end{array}$ & $10-20 \mathrm{~cm}$ & $20-30 \mathrm{~cm}$ & $30-40 \mathrm{~cm}$ \\
\hline 1 & $\begin{array}{c}\text { Stoneware Sherd } \\
3 \text { Clear Glass Sherds } \\
2 \text { Whiteware Sherds } \\
2 \text { Unidentifiable Metal Fragments }\end{array}$ & $\begin{array}{c}\text { Stoneware Sherd } \\
8 \text { Clear Glass Sherds } \\
\text { Brown Glass Sherd } \\
2 \text { Square Nails } \\
\text { Unidentifiable Metal Fragment }\end{array}$ & $\begin{array}{c}\text { Porcelain Cup Handle } \\
10 \text { Clear Glass Sherds } \\
6 \text { Square Nails }\end{array}$ & Clay \\
\hline 2 & $\begin{array}{c}\text { Red Brick Fragment } \\
2 \text { Clear Glass Sherds } \\
5 \text { Unidentifiable Metal Fragments }\end{array}$ & Clay & & \\
\hline 3 & $\begin{array}{c}\text { Clear Glass Sherd } \\
\text { Light Green Glass Sherd }\end{array}$ & $\begin{array}{c}\text { Red Brick Fragment } \\
\text { Clear Glass Sherd } \\
\text { Unidentifiable Metal Fragment }\end{array}$ & $\begin{array}{c}\text { Whiteware Sherd } \\
\text { Square Nail }\end{array}$ & Clay \\
\hline
\end{tabular}

200). Local potters produced a variety of glazed and unglazed wares during the late 1800s in Bastrop County. The white porcelain cup handle most likely postdates 1832 , when it was commonly manufactured in the United States (Barber 1976:126-127; Ivey and Fox 1981:35).

The other two construction items, two unlabeled red brick fragments, were crumbly, with large clasts, rounded edges, and generally very poorly made under low firing conditions. By the 1820s Anglo settlers were making their own crude bricks, and they continued to fire their own bricks through the first quarter of the twentieth century until the production of bricks became more industrialized(Steinbomer 1982:33-70). The specimens from 41BP668 are similar those made during the last quarter of the nineteenth-century in local kilns.

\section{Conclusions/Recommendations}

In summary, the red brick and square nails recovered from shovel tests suggest the house was likely constructed before 1900 . The artifacts on the other hand, suggest a longer period of occupation at the site. The porcelain, undecorated whiteware and stoneware may represent the earlier occupation, ca. 1875-1900, while the glass bottle sherds probably reflect a post-1930 occupation.

Without extensive archival research, we can state that the house remains and associated artifacts designated as 41BP668 presumably belonged to a J. Sanders. This site lies in the extreme northeastern corner of Tract D-130, a parcel listed as being owned by J. Sanders in 1929 (Bastrop County Map 1929). There are also household artifacts and a cistern in the north-central portion of this parcel documented as site 41BP473 (Sullo and Wormser 1996).

Nevertheless, this site has been heavily disturbed there are no intact structures, and the artifacts appear to be mixed. As such, we suggest that the site is ineligible for nomination to the NRHP, and no further work is recommended. 


\section{$41 B P 670$}

\section{Description}

The historic component at 41BP670 covers approximately $1,672 \mathrm{~m}^{2}$, consisting of gravel borrow pits, an alignment of hewn sandstone, remnants of a probable dam across an intermittent drainage, old fencing, and a few pieces of glass. It is located in and alongside an intermittent drainage (Figures 5-40 and 5-41) between 455$465 \mathrm{ft}$ in elevation. The southeastern portion of this site was used in

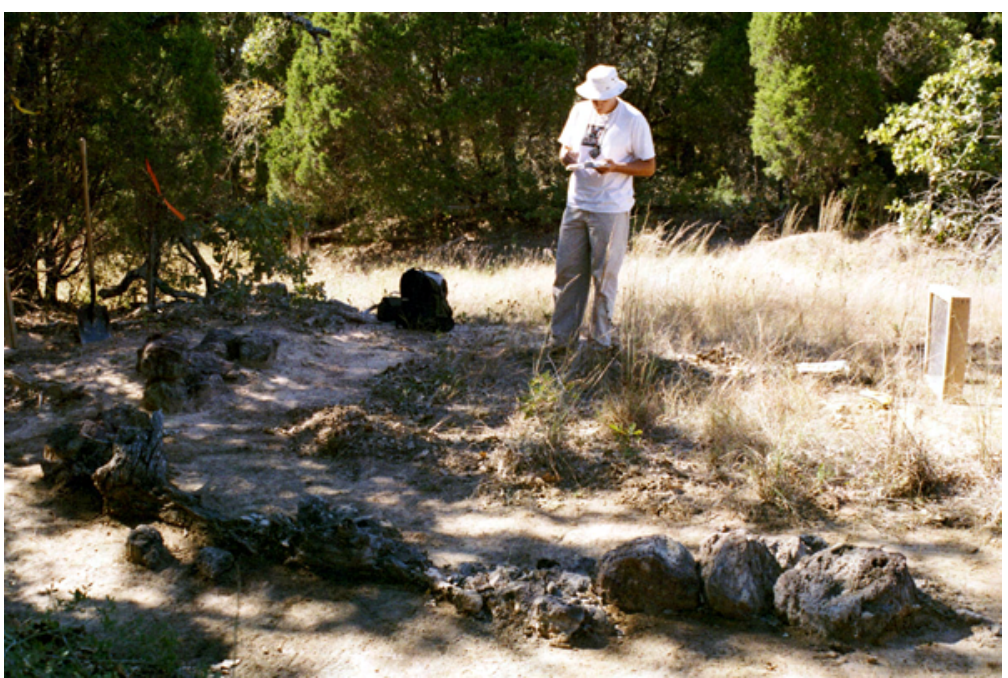

Figure 5-40. Jimmy Barrera recording sandstone structure remains at 41BP670; facing west. prehistoric times as a lithic procurement area (see Section I. Prehistoric Components). The area along the drainage in the western edge of the site is heavily wooded, but both sides of the drainage have apparently been cleared for farming. A pipeline right-of-way has been cleared through the center of the site. Although the soils are mapped (Baker 1979) as Axtell fine sandy loam ( $\mathrm{AfC} 2$ ), there is little left on the south and eastern portion of the site. However, north and west of the pipeline the soils are much deeper as evidenced in the creek cutbank.

\section{Levels of Work and Results}

The sandstone structural remains were carefully examined, photographed, and sketched (Figures 5-40 through 5-43). The stones were arranged in one layer of 6 to 10 -inch $(15 \times 25 \mathrm{~cm})$ thick pieces, but stacked vertically in two courses along the western wall. The stones were set on the underlying red clay, with no foundation trench, and no mortar. As shown, there are only two sides to this $10 \times 16 \frac{1}{2}$ feet $(\sim 3 \times 5 \mathrm{~m})$ structure. It is not known if all four sides were constructed, if they

FIGURE 5-41. REDACTED

Figure 5-41. Site map,41BP670. 


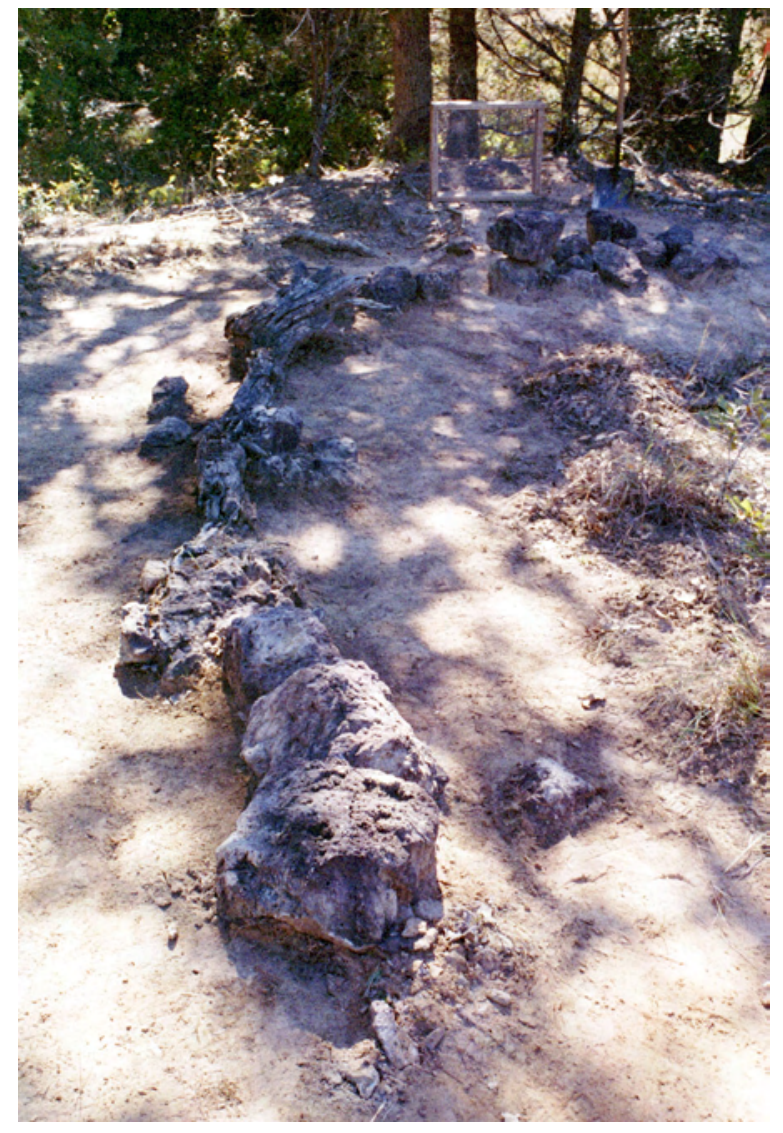

Figure 5-42. Sandstone structural remains at 41BP670; facing southeast.

were stone robbed for other purposes, or whether the other two sides were removed when the pipeline was built. There were no nails or other construction material to suggest a wooden superstructure, and no similar-sized sandstone was found along the edge of the right-of-way. Note that the south wall has an opening in it near the corner that has been filled in by a fallen tree. Also the south wall has a substantial, but very short north extending transverse wall.

Although heavily eroded, with 41BP670. excellent surface visibility, no artifacts were found around the structure. Four shovel tests were excavated in areas presumed to be the interior and exterior of the structure (see Figure 5-41). Red clay was encountered in all four between 3 and 8 $\mathrm{cm}$ below the surface, and no artifacts were found.

Soil samples were collected from eight shovel probes to evaluate them for soil susceptibility and $\mathrm{pH}$ values. The locations of these probes are shown on Figure 5-43. Note that Samples 5 through 8 are all on the outside of the structure, while Samples 1 through 4 are on the inside.

First we measured the soil susceptibility values of the eight samples and created a bar graph of those values, as shown in Figure 5-44. Quite simply, magnetic susceptibility in soils is enhanced by organic enrichment, especially by ashes from campfires (for a detailed explanation see, Heller and Evans 1995; Singer and Fine 1989). It is frequently used to identify buried paleosols and/or buried human occupation zones (e.g., Collins 1994; Gose and Nickels 2001).

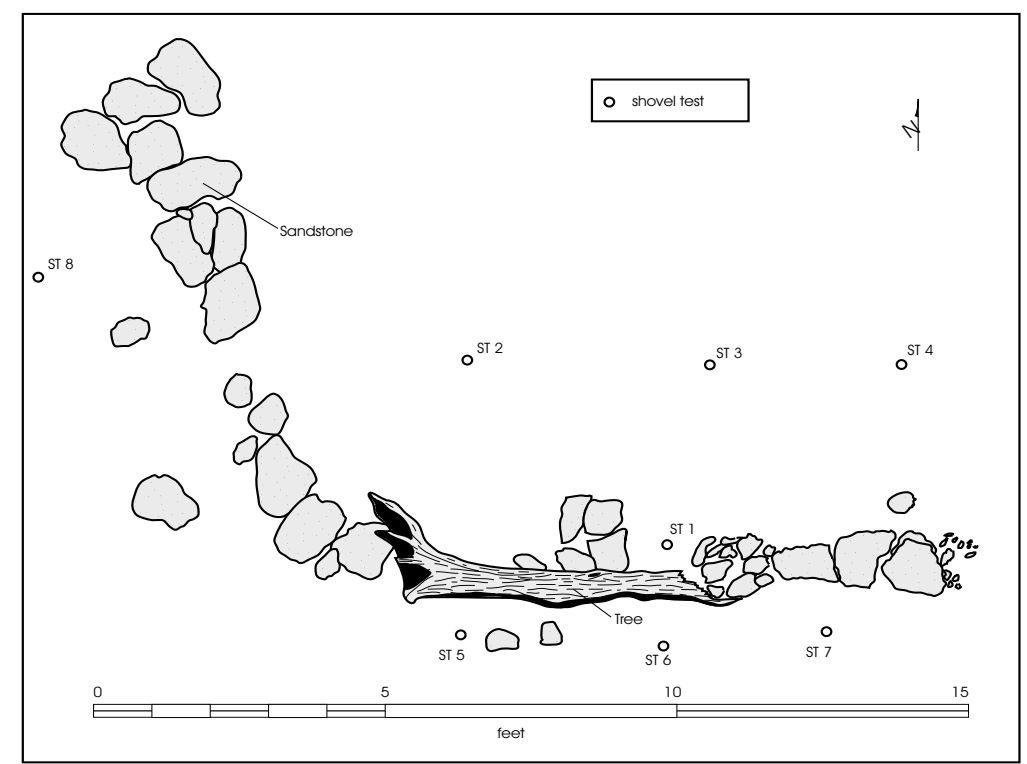

Figure 5-43. Sketched planview of sandstone structural remains at 


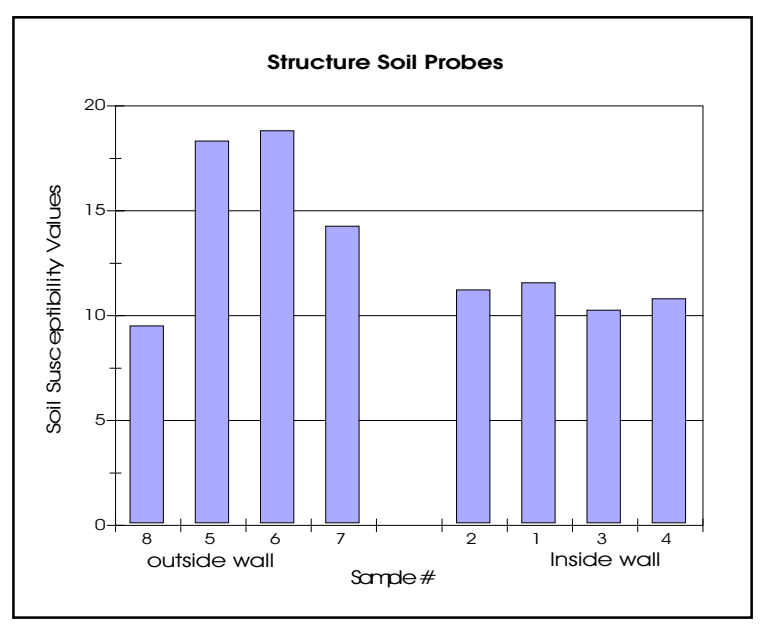

Figure 5-44. Soil susceptibility $\left(\mathrm{Xm} \mathrm{10} 0^{-6}\right)$ values collected from shovel probe samples around the structural walls from 41BP670; Samples 1-4 inside, others outside the wall.

The purpose here was to evaluate any differences in values inside the structure compared to outside. If burning took place inside the structure in a hearth or fireplace, a susceptibility value in that area should be enhanced. An examination of Figure 5-44 indicates that the values inside the structure (Samples 1-4) are significantly lower than those outside, except for Sample 8, and Samples 5-7 carry the highest values. Interpretation of these data is that the high values in Samples 5-7 are directly attributable to the rotting tree trunk lying along the south wall, and the lower value samples represent the normal soil susceptibility in the area. Thus, there is no evidence of burning in any of the eight samples. We were especially interested in Sample 1 because we thought the short, north jutting wall was a remanent of a chimney, however this hypothesis was not supported by the data.

Next, we measured the $\mathrm{pH}$ values of the eight samples and created a bar graph of those values, as shown in Figure 5-45. The amount of $\mathrm{pH}$ (phosphate) present in soils increases in areas where organic wastes have accumulated (Lewis 1978:310). Thus, as soil samples are evaluated, one would expect higher $\mathrm{pH}$ values to correlate with areas of increased human occupation, or animal wastes.

Finding no artifacts around the structure, and no evidence of burning, we suspected that the structure may have been a corral or pen enclosure for animals. If this was the case, then we would expect to see higher $\mathrm{pH}$ values inside the enclosure. However, as depicted in Figure 5-45, the high $\mathrm{pH}$ values are not inside the enclosure, but outside. Our interpretation from this dataset is that the enclosure was not used to hold animals. At this point of investigation, the function of the structure is unknown.

The available information still does not allow for a convincing determination of the structure's function. It could be that it was not used for agricultural purposes, but was used as a storehouse associated with the gravel quarrying operation.

Approximately $37 \mathrm{~m}$ up the creek from the structure are the remnants of a sandstone dam. At

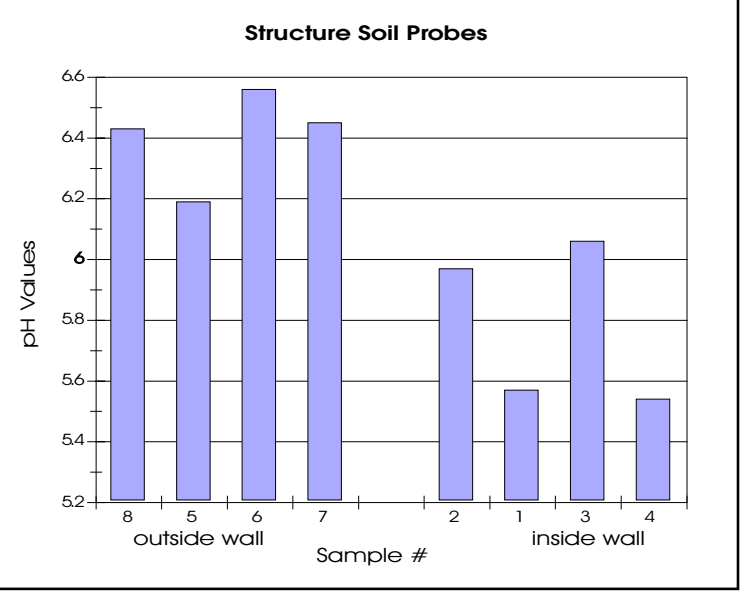

Figure 5-45. $\mathrm{pH}$ values collected from shovel probe samples around the structural walls from 41BP670; Samples 1-4 inside, others outside the wall. 
this point, the creek is about $6 \mathrm{~m}$ wide $\mathrm{x} 3 \mathrm{~m}$ deep (Figure 5-46). All that remains of the dam is approximately eight roughly hewn sandstones on each side of the creek. Next to these are the remains of a fence corner on the north side of the creek, rusty barbed wire strung across the creek, and another fence post on the south side of the creek.

In the creek bottom near the dam we found a clear glass Mason jar top, a brown glass sherd that looked modern, a modern spray can, and a brown whiskey bottle neck. Although the Mason fruit jar was being made as early as 1858 , this glass lid is very clear and well made, suggesting it is post1930.

The whiskey bottle neck is much older (Figure 5-47). The two mold seams on this highly polished, dark brown bottle stop an inch below the bottom of the lip, indicating it was made in a three-part leafmold. This type of mold was most commonly used in the late 1800s, but most definitely before 1903 (Munsey 1970). The bottle also has whittle marks, a wavy surface appearance, indicating it was likely blown in a cold mold during the start of the production day (Munsey 1970:46). The lip is a laid-on ring, smoothed or finished with a finishing tool (post1850), and the point of contact between the lip and the neck is very smooth, virtually undetectable. All together, the laid-on ring, tooled lip and undetectable seam indicate the bottle was made after 1880 . Finally, its color is another indicator of its age. Dark brown, thick bottle glass was a predominant color for whiskey bottles before 1900 (Munsey 1970). In sum, this bottle probably was manufactured between 1880 and 1900.

\section{Conclusions/Recommendations}

It was not possible to determine when and how the sandstone structure was used. It could have

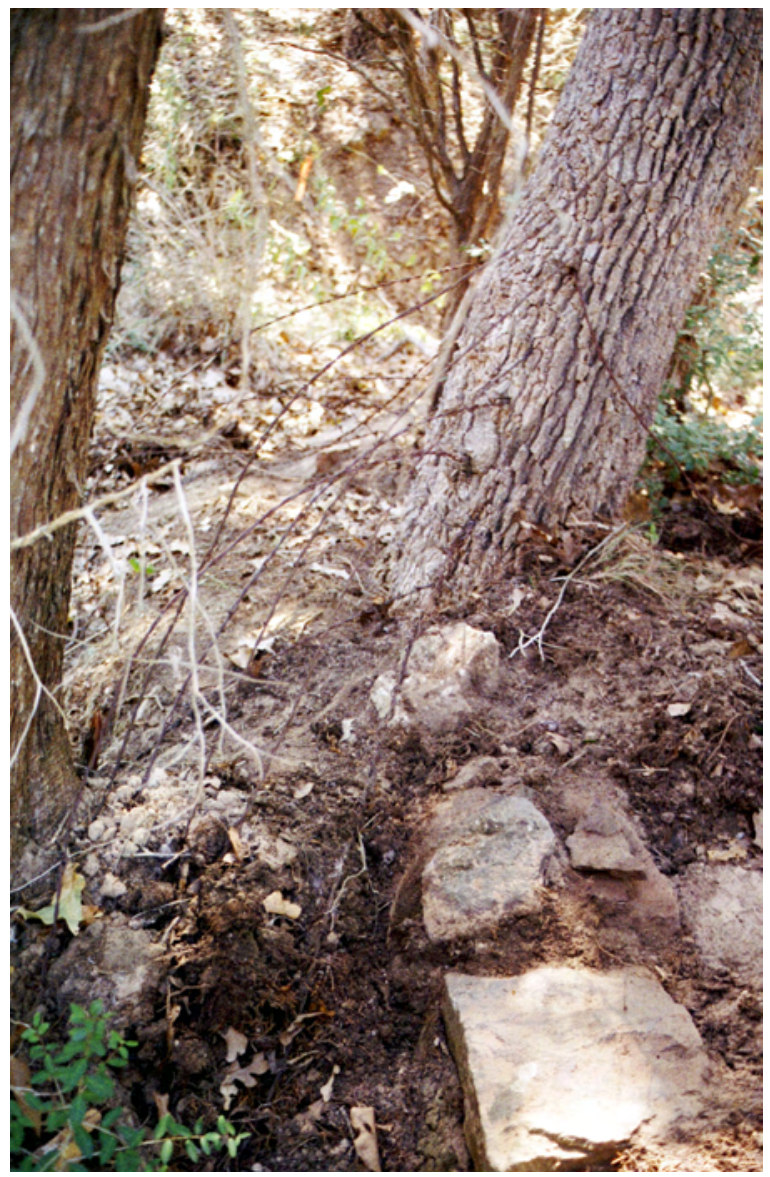

Figure 5-46. Remains of the dam on the creek at 41BP670; facing west.

been inhabited by humans or animals, or used as a utility shed for the gravel pit operation. We could not determine the age of the dam either. The few artifacts on the site indicate an age range from 1880 to modern. The oldest was a whiskey bottle neck found in the creek bottom $14 \mathrm{~m}$ upstream from the dam.

Site 41BP670 is on the southern portion of a 100 -acre property owned by Mr. S. Vonkochneritz in 1929 (Bastrop County Map 2003). The discovery of artifacts in the area around the Vonkochneritz farmstead (41BP663) could place an occupation there as early as 1880 (see discussion of 41BP663 in this section). The sandstone structure and dam, and the gravel quarry operation may be associated 


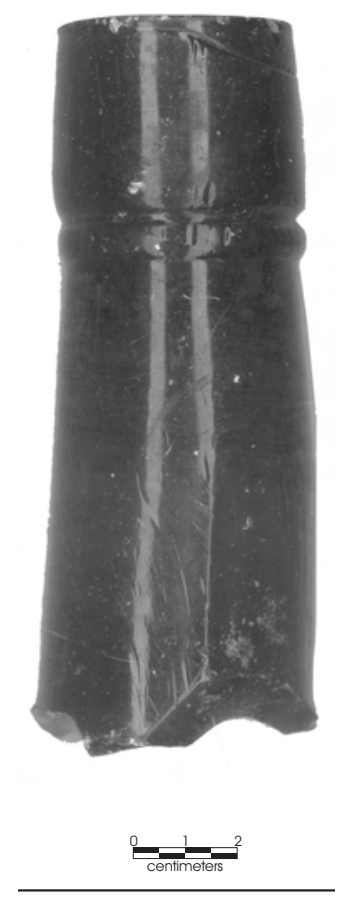

Figure 5-47. This dark brown whiskey bottle neck dating to between 1880 and 1900 was found in the creek bottom above the dam at 41BP670.

with the occupation at 41BP663. The old whiskey bottle found just upstream from the dam dates to that same time period, and it is possibly related to the stone structure but this association is weak.

The site lacks clearly associated and datable artifacts, the sandstone structure and dam has limited interpretive potential, and the site is not linked with a known historical figure. As such, we assess the site as ineligible for nomination to the NRHP, and no further work is recommended.

\section{Section III. Isolated Finds}

A total of seven prehistoric and two historic isolated finds were recorded. All were plotted on topographic maps using GPS. In the case of prehistoric items, an intensive surface inspection was conducted and a sufficient number of shovel tests were excavated to determine that they were not in the context of a site. In the cases of historic items, an intensive surface inspection was considered sufficient.

\section{Prehistoric Isolated Finds}

Isolated Find 1 consists of one flake and two tiny pieces of fire-cracked rock within the upper 20 $\mathrm{cm}$ of Shovel Test O2 in Area B. The artifacts were clearly within disturbed colluvium; dense gravels and angular pieces of rotted bedrock were encountered from the surface to $60 \mathrm{~cm}$. Eight shovel tests placed around Shovel Test O2 were negative (Figure 5-48).

Isolated Find 2 is a single cracked, but articulated burned rock found between $40-50 \mathrm{~cm}$ below the surface in Shovel Test C4, Area B. This burned rock was found mixed with dense gravels on the upper boundary of the underlying red clay $\mathrm{Bt}$ horizon. In addition to systematic transect shovel tests placed around Shovel Test C4, we excavated an additional four shovel tests within five meters in the four cardinal directions; all were negative (Figure 5-49).

Isolated Find 3 is a single piece of fire-cracked rock recovered from the upper $10 \mathrm{~cm}$ of Shovel Test J2, Area A. Gravels were encountered in all levels until clay was encountered $35 \mathrm{~cm}$ below the surface. In addition to systematic transect shovel tests placed around Shovel Test J2, an additional four shovel tests placed within five meters in the four cardinal directions were negative (Figure 5$50)$.

Isolated Find 4 consists of a single fire-cracked rock and charcoal found between $60-70 \mathrm{~cm}$ below the surface in Shovel Test F5, in Area F. However, 


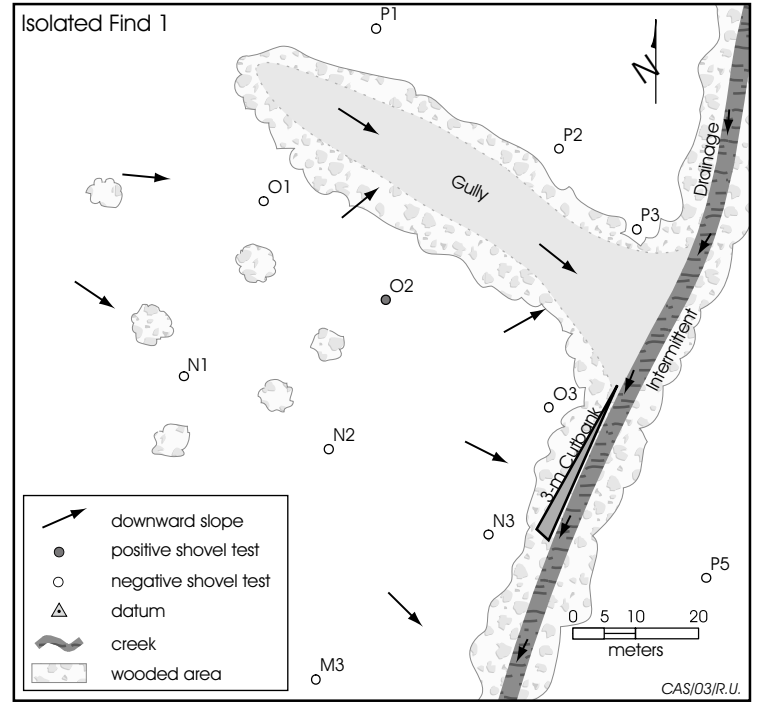

Figure 5-48. Shovel tests in the area of Isolated Find 1.

there are several problems with their context. While Shovel Test F5 was placed on a ridge between two drainages classified as a high site probability area, it was also on a 30 percent slope adjacent to an active floodplain. Mottled orange clay was encountered 20-30 cm deep, $20 \mathrm{~cm}$ of clayey alluvium was lying above the fire cracked rock and charcoal, and the solid clay Bt horizon was just below them. Three additional shovel tests

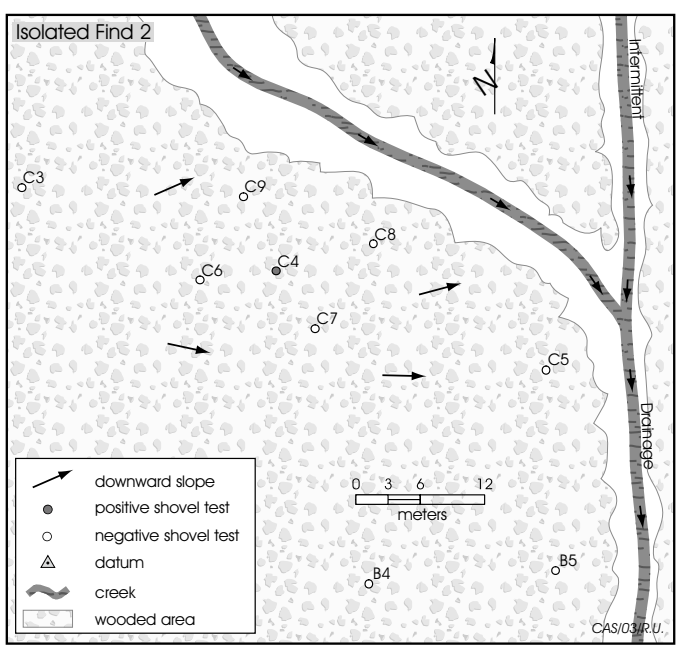

Figure 5-49. Shovel tests in the area of Isolated Find 2. placed on the least eroded areas around Shovel Test F5 were negative, encountering the Bt horizon at 5, 22, and $35 \mathrm{~cm}$ (Figure 5-51).

Isolated Find 5 is a single flake with crushed gravels in the same level, $20-30 \mathrm{~cm}$ below the surface in Shovel Test B4, Area I. The location of this shovel test is on the edge of a bladed, unimproved road, in an area that has been cultivated (Abner Scott, personal communication January 16, 2002). It is also near a concrete structure

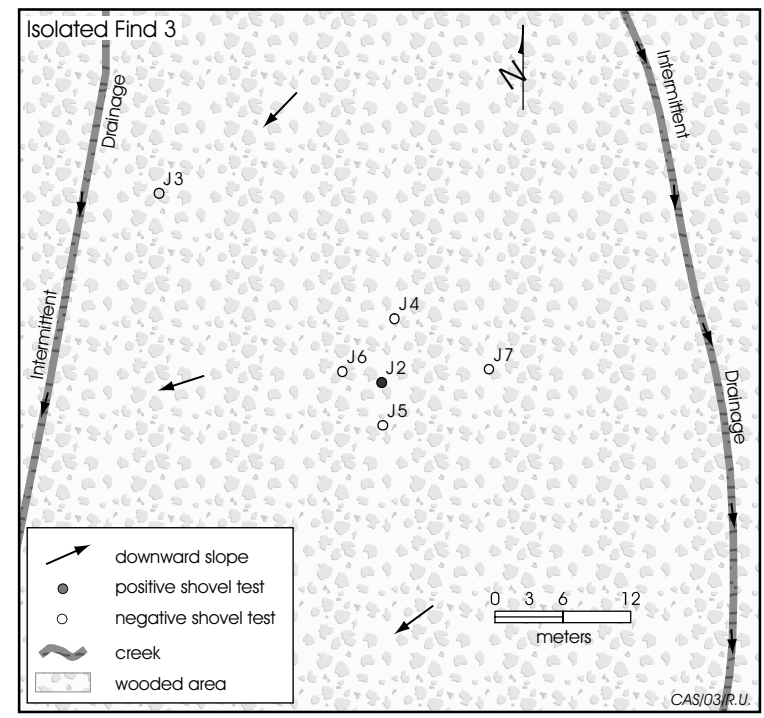

Figure 5-50. Shovel tests in the area of Isolated Find 3.

constructed during World War II, and is on the periphery of an area used as a training area for heavy equipment operators (Wormser and Leshley 1995). Systematic transect shovel tests within $30 \mathrm{~m}$ or less of Shovel Test B4 were all negative (Figure 5-52).

Isolated Find 6 is a single flake found in the upper $10 \mathrm{~cm}$ of Shovel Test J32 in Area J, just above the active floodplain of Big Sandy Creek. Mottled clay was encountered in this shovel test from the surface to the underlying Bt horizon at $30 \mathrm{~cm}$. In 


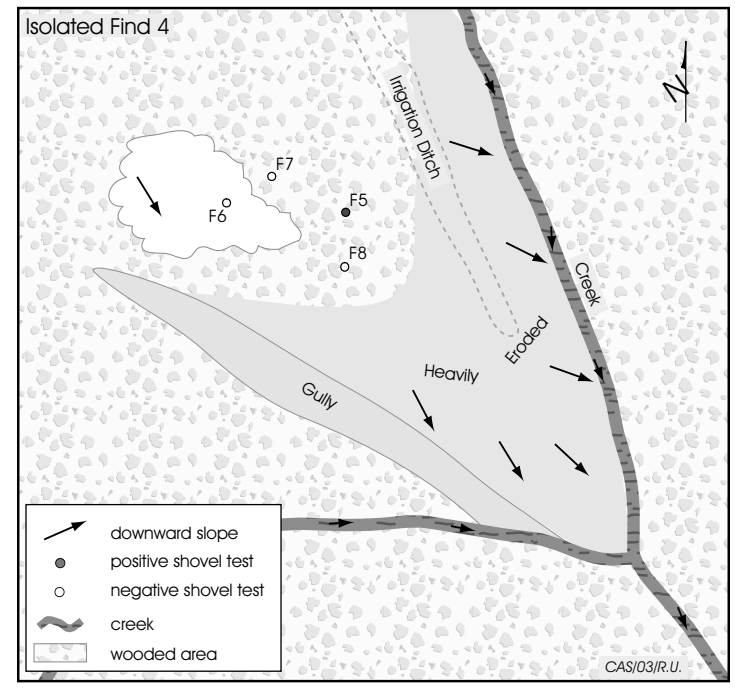

Figure 5-51. Shovel tests in the area of Isolated Find 4.

addition to systematic transect shovel tests placed within $30 \mathrm{~m}$ around Shovel Test J2, an additional four shovel tests placed within five meters of it in the four cardinal directions; all were negative, and all encountered the Bt horizon between $35-40 \mathrm{~cm}$ below the surface (Figure 5-53).

Isolated Find 7 is a single interior flake found between $50-60 \mathrm{~cm}$ below the surface in Shovel Test E1, Area K. In addition to systematic transect shovel tests, we placed four shovel tests in the four cardinal directions within five meters of Shovel Test E1 (Figure 5-54). All four were terminated on orange and gray clay between $80-100 \mathrm{~cm}$ below the surface, and none produced artifacts.

\section{Historic Isolated Finds}

Isolated Find 8 consists of two small decorated whiteware sherds lying on a heavily eroded surface beside the upper reaches of a small tributary in Area A. Both pieces were decorated with a printed pattern not unlike most 1950s dinnerware. Although we closely examined the surrounding surface area and cutbanks, no other artifacts were
FIGURE 5-52. REDACTED

Figure 5-52. Shovel tests in the area of Isolated Find 5.

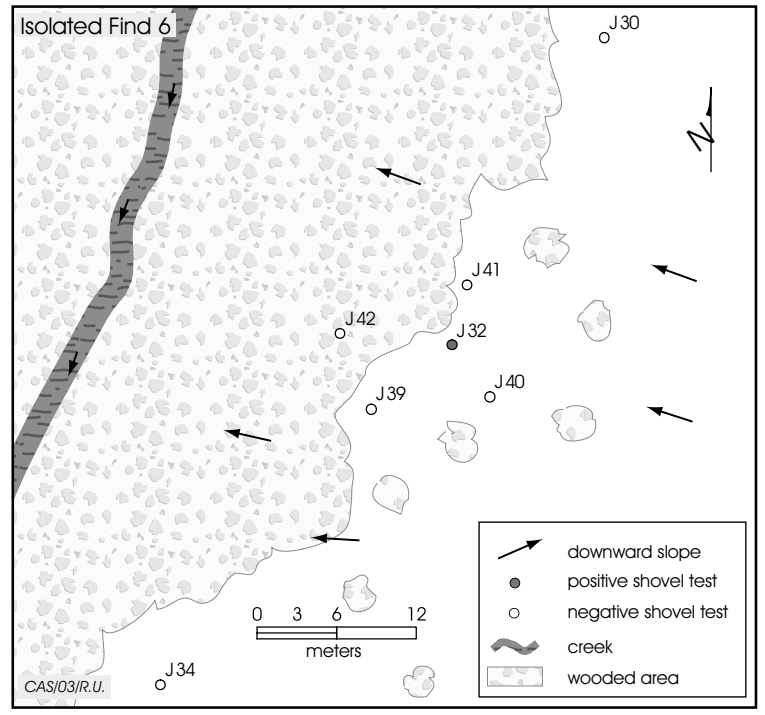

Figure 5-53. Shovel tests in the area of Isolated Find 6.

observed. The closest documented historic site is 41BP479, situated upslope with early to mid-twentieth century house remains, an extensive trash scatter, and an abandoned 1953 Chevrolet (Robinson et al. 1997; David Nickels, personal observation 2003). 


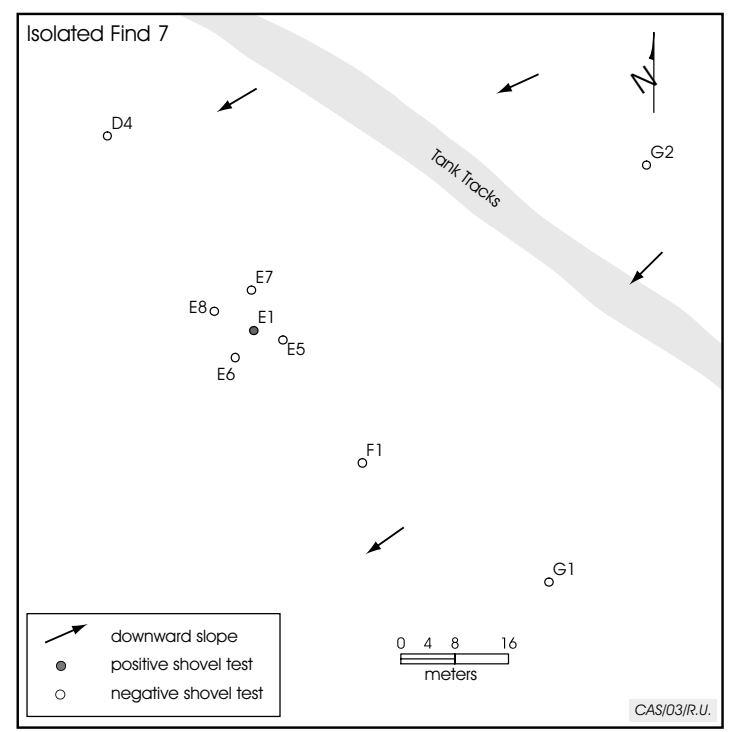

Figure 5-54. Shovel tests in the area of Isolated Find 7.
Isolated Find 9 is a 10-cm long, square, amber snuff bottle found lying in the bottom of a small drainage in the eastern portion of Area A. Its age likely dates to the latter part of the nineteenth century. It has an offset, round mold seam, indicating it was machine made; the absence of embossing suggesting it had been paper labeled; and a cork stopper opening. However, there is no series of raised dots on its base (a possible measure of the strength of the snuff) that would indicate it was manufactured before 1900. Tall, square snuffbottles were produced around the turn of the century (Munsey 1970:77). Although we thorough examined of the drainage bottom, and the surrounding area's surface, only a fragmented and rusted tin can was found in the drainage and it could not be related to the snuff bottle. 


\section{Chapter 6}

\section{Research Design Issues}

\section{David L. Nickels}

\section{Introduction}

In Chapter 4 we discussed certain issues that could possibly be addressed by the completion of this survey. In turn, we detailed our methods for conducting the survey so that we could gather the information we needed to address the research issues. This chapter now discusses what we learned or did not learn. It is divided into two sections. The first section discusses issues directly associated with the prehistoric period, while the second section deals with the occupation and development of land that is now Camp Swift during the historic period.

With the completion of this survey, all 11,500 acres of Camp Swift have been surveyed. Since the first survey was conducted in 1979, this final survey finished 24 years later, and numerous survey crews using varying survey methods, a total of 181 archaeological sites have been documented on the 11,500 acres comprising the currently configured Camp Swift. There are 106 prehistoric components and 90 historic components on the 181 sites (17 are multicomponent). Technological advances now allow us to compare and contrast multiple lines of evidence looking for settlement patterns across the landscape.

\section{Section I: Prehistoric Issues}

Prehistoric SiteDensity andDistribution

The 106 prehistoric component types are totaled by site type in Table 6-1. Traditionally, prehistoric site types classified as either open campsites, lithic procurement sites, and lithic scatters were identified during the surveys. Open campsites were identified by the presence of intact burned rock features or scattered fire-cracked rock, evidence of late-stage reduced lithic tools, and a wide variety of either chipped or ground stone tools. In some cases an open campsite had a combination of all three; in some cases a single hearth or scattered burned rock with only a few flakes was also typed as an open campsite. The key factor in classifying a site as an open campsite was the presence of burned rock.

Lithic procurement sites were identified on the basis of evidence that gravel deposits were used as a source of raw material. Within the gravels should be evidence of early stage reduction in the form of tested cobbles, minimally scarred cores, large exterior flakes, and possibly quarry blanks broken

Table 6-1. Prehistoric component types documented at Camp Swift.

\begin{tabular}{|c|c|}
\hline Prehistoric Components & Number \\
\hline Open Campsites & 74 \\
\hline Lithic Scatters & 21 \\
\hline Lithic Procurement & 11 \\
\hline Total & $\mathbf{1 0 6}$ \\
\hline
\end{tabular}


during manufacture. The absence of campsite features and material, the presence of cores and flakes regardless of stages of reduction, and possibly crudely flaked bifaces broken during manufacture or discarded broken tools identified sites as lithic scatters.

Although today's survey standards and techniques are more stringent than those of 20-30 years ago, there is a good beginning from which to build a Geographic Information Systems (GIS) database. The 106 prehistoric components were found over an 11,500 acre area; that equates to only one site every 108.5 acres. During the current survey, we found nine prehistoric components over a 307 acre area; that equates to one site every 34 acres. Regardless of the numerous variables that can effect the results of any survey, we have to presume that the multiple surveys done at Camp Swift have created an overall representative, although not complete, sample of sites both discovered and undiscovered. Using the data obtained since the first formal survey of Camp Swift in 1979 (Skelton and Freeman 1979), it is possible to examine prehistoric density and distribution through time.

\section{Occupation of the Area Through Time}

As discussed below, a total of 90 historic components have been documented across the 11,500 -acre area, or one site per every 128 acres. Notably, these sites range in ages from about 1850 to 1940 , or 90 years. Compare that to the 106 prehistoric sites that have been found within the same area, and range in age from perhaps 250 to perhaps 11,000 years old. Although site types are categorically named differently, today's trash scatters are somewhat analogous to yesterday's lithic scatters, and today's houses and farmsteads are essentially yesterday's open campsites. Native Americans buried the deceased in isolated graves and cemeteries, just as the Anglo Americans did.
Native Americans procured raw material for stone tools at procurement sites, and much later workers mined lignite in the area in the early 1900s.

If one disregards the numerous factors influencing occupation of the area through time, in simple terms, the numbers mean that Native Americans occupied the land on sites in nearly the same spatial proximity to each other as Anglo Americans did, but over an 11,000-year period rather than a 90year period. This in turn suggests that Native Americans either used the area very sparsely over an 11,000-year period or they used it intensively during specific time periods, while abandoning it for much longer periods.

A total of 41 projectile points have been "typed", with 28 of those clearly assigned a named type. For this analysis, we elect to not use those 11 points categorized generally as Archaic, Middle Archaic, Late Archaic, or dart, as they are too generic, or in some cases perhaps just a guess (e.g., Boyd 1997:262-264; Collins 1998; Hall 1982:340-348; Turner and Hester 1999:246-249). In the case of arrow points, we believe the use of arrow points is more clearly defined so as to place them in the Late Prehistoric period. The Clear Fork gouge has been found in various temporal period contexts so we did not assign it to a specific time period.

Thus, we have 30 diagnostic stone tools with which to evaluate the occupation of the Camp Swift area through time. There are also two sites where sandy paste, Native American pottery has been found, and we feel confident placing the occupation of those sites within the Late Prehistoric period. We caveat the following discussion however, by acknowledging that 1) this dataset was derived from both survey and excavations, 2) older diagnostic artifacts may have been reused by later inhabitants, 3) the recovery of diagnostic artifacts 
Table 6-2. Diagnostic artifacts recovered from Camp Swift sites.

\begin{tabular}{|c|c|c|c|c|c|c|c|c|c|c|c|c|c|c|c|c|c|c|c|c|c|c|c|c|c|}
\hline Site & 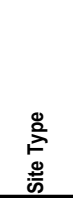 & 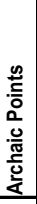 & 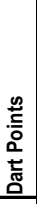 & 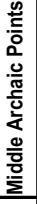 & 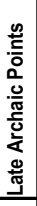 & 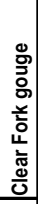 & 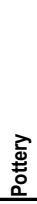 & 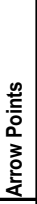 & 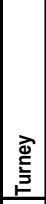 & \begin{tabular}{|l|} 
긴 \\
은 \\
닌 \\
\end{tabular} & 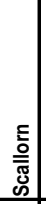 & 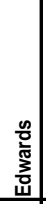 & $\stackrel{\stackrel{\varrho}{\bar{\omega}}}{\underline{\underline{m}}}$ & 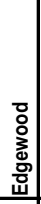 & 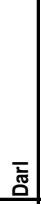 & $\begin{array}{l}\grave{b} \\
\dot{w} \\
\tilde{w} \\
\end{array}$ & 은 & $\begin{array}{l}\overline{\bar{\Phi}} \\
\stackrel{ \pm}{0} \\
\Sigma\end{array}$ & 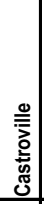 & 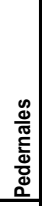 & 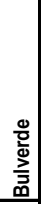 & $\begin{array}{l} \pm \\
\frac{0}{0} \\
\frac{2}{2}\end{array}$ & 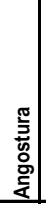 & $\frac{n}{\frac{n}{2}}$ & Totals \\
\hline BP100 & Camp & & & & & & $\mathrm{x}$ & & & & & & & & & & & & & & & & & & $\mathbf{0}$ \\
\hline BP121 & Camp & & & & & & & & & & & & & & & & & 1 & & & & & & & 1 \\
\hline BP128 & Proc & & & & & & & & & & & 1 & & & & & & & & & & & & & 1 \\
\hline BP380 & Proc & & & & & & & & & & & & & & & & & & & 1 & & & & & 1 \\
\hline BP381 & Camp & & & & & & & & & & & & & & & & & & & & 1 & & & & 1 \\
\hline BP389 & Proc & & & & & & & & & & & & & & & & 1 & & & & & & & & 1 \\
\hline BP390 & Proc & & & & & & & & & & & & & & & & & & & & & 1 & & & 1 \\
\hline BP391 & Camp & & & & & & & & & & 1 & & & & & & & & & & & & & & 1 \\
\hline BP392 & Camp & & 1 & & & & & & & & & & & & & & & & & & & & & & 1 \\
\hline BP397 & Proc & 1 & & & & & & & & & & & & & & & & & & & & & & & 1 \\
\hline BP477 & Camp & & & & & & & & & & 1 & & & & & & & & & & & & & & 1 \\
\hline BP485 & Camp & & & 1 & 4 & & & & & & & & 1 & & & & & & & 1 & & & 1 & & 8 \\
\hline BP486 & Camp & & & & & & & & & & & & & & & & & & & 1 & & & & & 1 \\
\hline BP488 & Camp & & & & 1 & & $x$ & 2 & & & 1 & & & & & & & & & & & & & & 4 \\
\hline BP495 & Camp & & & & & 1 & & & & & 3 & & & & 1 & & & & & & & & & 1 & 6 \\
\hline BP496 & Camp & & & & & & & & & & & & & 1 & & & & & & & & & & & 1 \\
\hline BP497 & Camp & & & & & & & & & & 1 & & & & & & & & & & & & & & 1 \\
\hline BP506 & Camp & 1 & & & & & & & & & 2 & & & & & & & & & & & & & & 3 \\
\hline BP520 & Camp & & 1 & & & & & & & & & & & & & & & & & & & & & & 1 \\
\hline BP521 & Camp & & & & & & & & & 1 & 1 & & & & & 1 & & & 1 & & & & & & 4 \\
\hline BP528 & Camp & & 1 & & & & & & & & & & & & & & & & & & & & & & 1 \\
\hline BP530 & Camp & & & & & & & & 1 & & & & & & & & & & & & & & & & 1 \\
\hline BP94 & Camp & & & & & & & & & & & & & & & 1 & & & & & & & & & 1 \\
\hline & & & & & & & & & & & & & & & & & & & & & & & & & \\
\hline Totals & & 2 & 3 & 1 & 5 & 1 & 2 & 2 & 1 & 1 & 10 & 1 & 1 & 1 & 1 & 2 & 1 & 1 & 1 & 3 & 1 & 1 & 1 & 1 & 44 \\
\hline & & & & & & & & & & & & & & & & & & & & & & & & & \\
\hline & & & & & & & & \multicolumn{5}{|c|}{ Late Prehistoric } & & & & \multicolumn{4}{|c|}{ Late Archaic } & & \multicolumn{5}{|c|}{ Early Archaic/ } \\
\hline & & & & & & & & & \multicolumn{3}{|c|}{\begin{tabular}{l|}
$(n=18)$ \\
\end{tabular}} & & & & & \multicolumn{3}{|c|}{$(n=11)$} & & & \multicolumn{5}{|c|}{ Paleo $(n=3)$} \\
\hline
\end{tabular}

can be directly attributable to visibility, and 4) in this analysis the absence of diagnostic artifacts excludes the site(s) from study. Undoubtedly, an untold number more have been collected from sites at Camp Swift in historic and modern times, but we'll work with the available data; 32 diagnostic artifacts from 23 sites. Table 62 lists the sites with typed points and pottery used in our analysis.

Based upon these 32 diagnostic artifacts, Figure 6-1 shows the number of temporal components per every 100-year span at Camp Swift, but standardized for the length of each

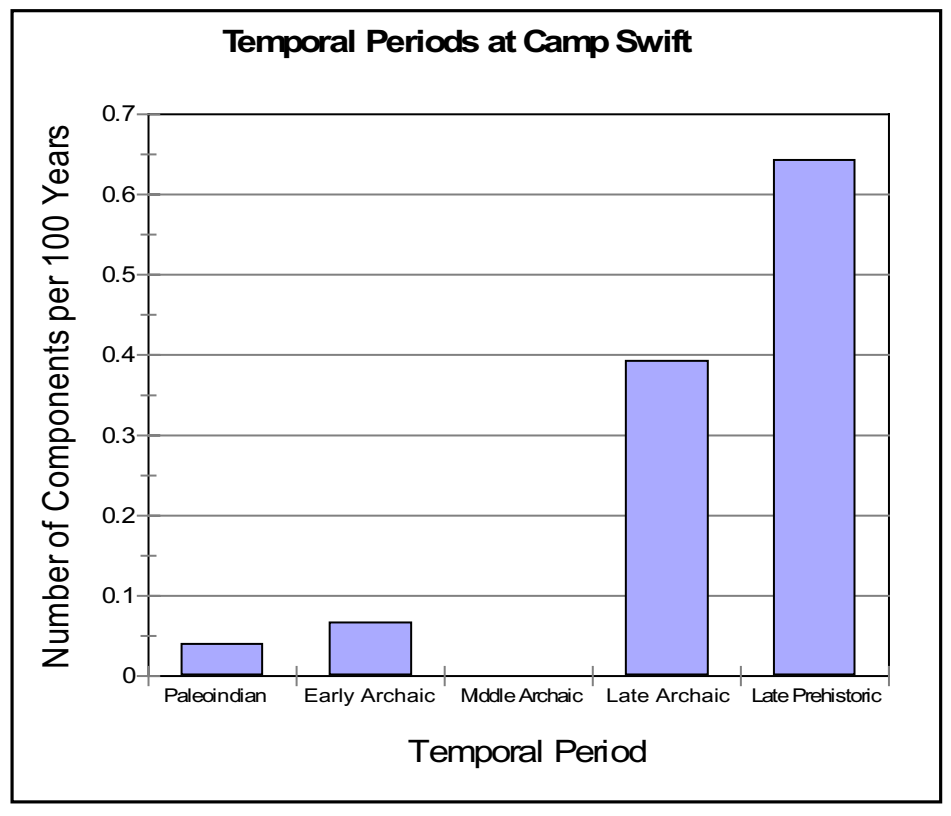

Figure 6-1. Temporal periods represented by diagnostic artifacts. 
temporal period. In other words, we used Michael Collins' (1995:376) chronologies of point types as the basis for what point types were produced in the various time periods defined for Central Texas, then divided the number of years for that period into the number of points found for that period and multiplied by 100 years. For example, the Late Archaic period spans a 2,800-year period, from 4000-1200 B.P., and there are 11 Late Archaic diagnostic artifacts. Therefore, $11 \div 2,800=.0039$ gives us the number of components per year, and we then multiply $.0039 \times 100$ (years), we get the number of components per 100 years (.3928). We do not assume that all periods were continuously occupied, but these calculations provide a basis for assessing gross temporal patterns of occupational intensity.

Based upon a limited number of diagnostic artifacts that we may presume represent the overall use of the Camp Swift area in prehistory, the inference is that the area was used infrequently during the Paleoindian and Early Archaic periods, and was used much more frequently during the Late Archaic (Figure 6-1). It was then most heavily occupied during the Late Prehistoric period.

Conspicuously absent however, are any diagnostic artifacts associated with the Middle Archaic period (see Table 6-2, and Figure 6-1), approximately 60004000 B.P. This phenomena is not unusual in certain regions of Texas. Although the Middle Archaic period is viewed as occurring earlier in the High Plains for example (Johnson and Holliday 1986:46), that area was all but abandoned during the 3,000-yeardry and warm
Altithermal (Hughes 1991). The drier regions of Texas were abandoned during the Middle Archaic. During this same period, Native American populations were concentrated in Central Texas near the Balcones Escarpment where numerous springs flowed and game and plant foodstuffs were abundant.

\section{Distances to Water}

First, we plotted all 106 components over drainage distributions available from the Texas Natural Resources Conservation Commission (TNRCC). That data outlines the five major drainages and their first-order tributaries on Camp Swift; i.e., Big Sandy Creek, McLaughlin Creek, Dogwood Creek, Dogwood Branch, Spring Branch, and Harris Creek. We then calculated the distance from various site types to the closest water source. Overall, campsites were located from between $1 \mathrm{~m}$ and $580 \mathrm{~m}$ to a water source (Figure 6-2). On average, the 66 open campsites discovered during previous surveys are $165 \mathrm{~m}$ from the nearest water source, while the eight open campsites discovered during the current survey are $130 \mathrm{~m}$ from the

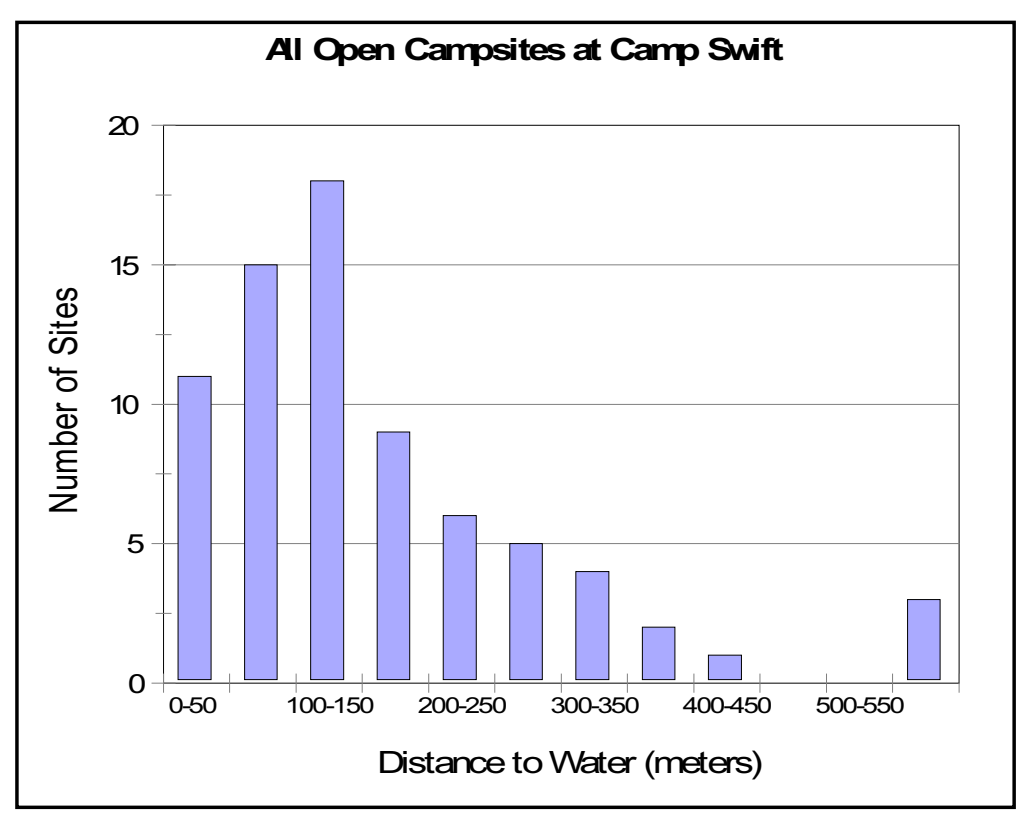

Figure 6-2. Distances to water from all 74 open campsites. 
Table 6-3. Distances of open campsites at Camp Swift with diagnostic artifacts to water.

\begin{tabular}{|l|c|c|c|}
\hline \multicolumn{1}{|c|}{ Period } & $\begin{array}{c}\text { No. Open Campsites } \\
\text { w/ Diagnostic Artifacts }\end{array}$ & $\begin{array}{c}\text { No. Diagnostic } \\
\text { Artifacts }\end{array}$ & $\begin{array}{c}\text { Average Distance } \\
\text { to Water (meters) }\end{array}$ \\
\hline Late Prehistoric & 11 & 18 & 235 \\
\hline Late Archaic & 10 & 11 & 190 \\
\hline Early Archaic & 2 & 2 & 306 \\
\hline Paleoindian & 1 & 1 & 215 \\
\hline
\end{tabular}

nearest water source; not a significant difference.

The modern hydrology is not representative of all periods during the past 12,000 years. Rather, it likely represents only periodic episodes over the past age span, and that there were obvious cyclical wet and dry periods. As discussed in the following paragraphs, diagnostic artifacts at Camp Swift represent the Late Prehistoric, Late Archaic, Early Archaic, and Paleoindian periods. Admittedly problematic because of the small number of diagnostic artifacts, distances of open campsites to water during each of these periods are shown in Table 63 and Figure 6-3. Before reading the following more detailed discussion on sites with diagnostic

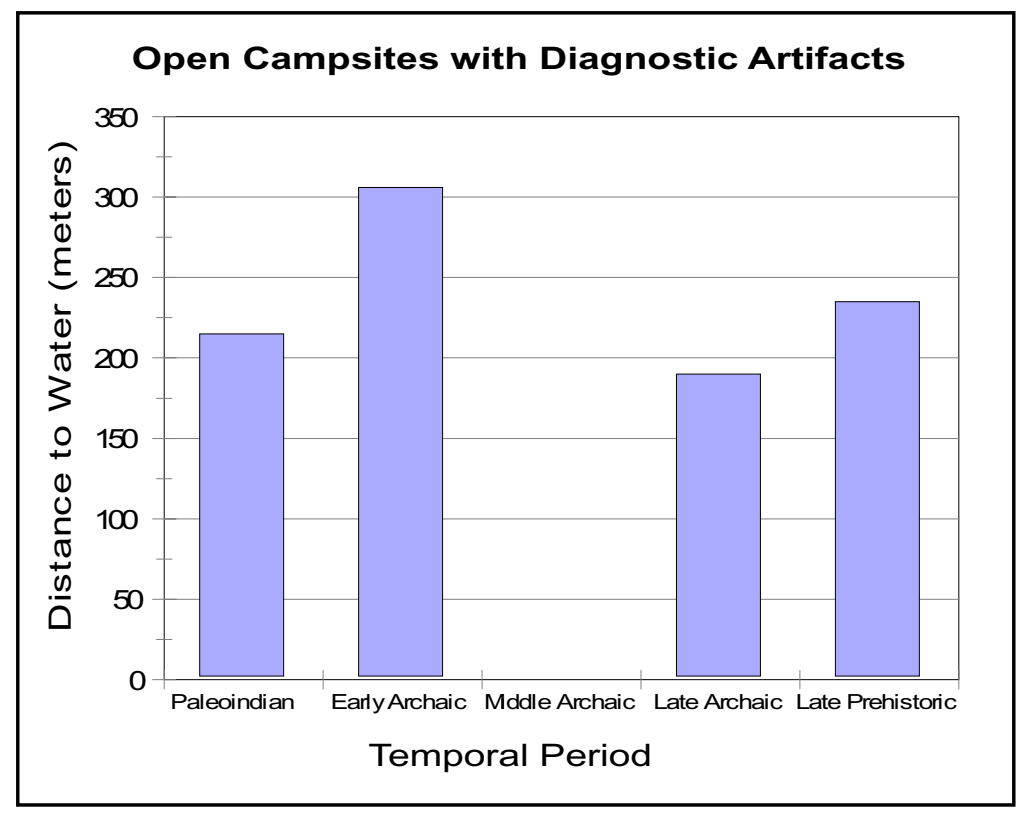

Figure 6-3. Distance to water from open campsites with diagnostic artifacts. artifacts, the astute reader will note that some sites contain diagnostic artifacts from more than one period.

The implication is campsites were located closer to water during the 2,800-year Late Archaic period than at any other time. This coincides with a period of wetter conditions noted in biosilica, stable isotopes, bog pollen and microfauna studies (Bousman 1998; Brown 1998; Humphrey and Ferring 1994; Robinson 1979, 1982).

Overall, the average distance from all 74 open campsite components to water is $163 \mathrm{~m}$; however, we have diagnostic artifacts from only 14 of the 74

(20.3 percent) open campsites. That being the case, we cannot presume for example, that the other 59 sites could all date to one time period (even the Middle Archaic), or that they could be equally divided among all time periods. Using the 15 components with diagnostic artifacts as a sample, and the fact that the distance of $190 \mathrm{~m}$ during the Late Archaic is closer to the overall distance of $163 \mathrm{~m}$, there is a high probability that many of the 59 unknowns are likely Late Archaic occupations. As such, we suggest that the data are likely skewed by Late Archaic occupations. 
Next, we calculated the distances from open campsites to lithic procurement sites. The measurements range from 140 to 2,424 meters. The average distance from campsite to procurement site is $1,029 \mathrm{~m}$, but the distribution is heavily skewed with a mode between 400-600 meters (Figure 6-4).

The pie chart shown in Figure 6-5 shows the number of campsites that are closest to the 11 procurement sites. Notably 41BP92, 41BP97, 41BP98 and 41BP670 are closer to more campsites than the remaining seven procurement sites, and assuming the quality of raw

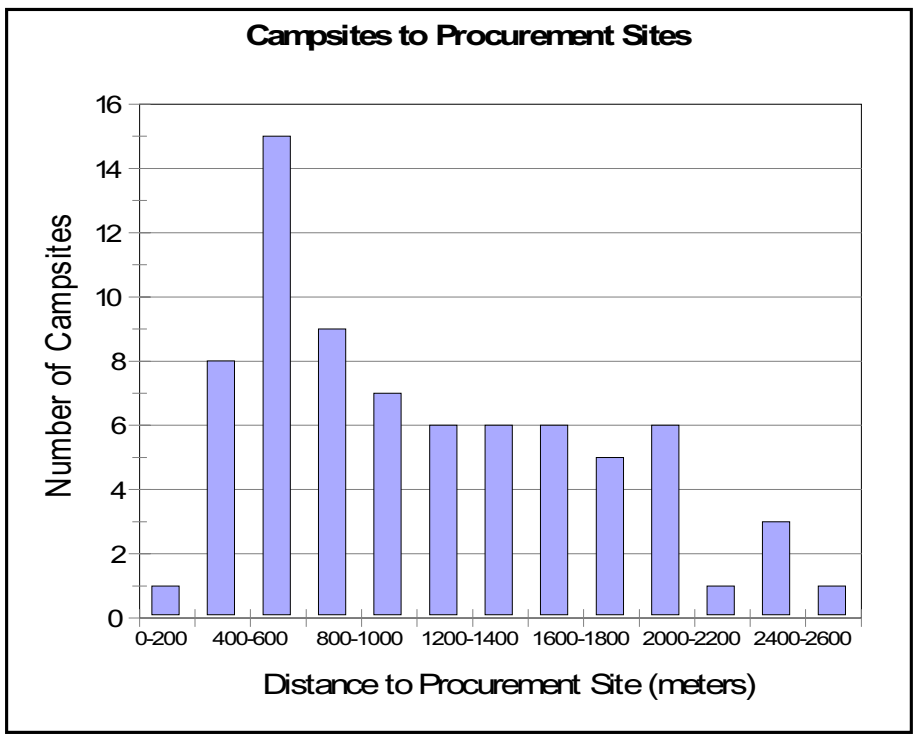

Figure 6-4. Distances to lithic procurement sites from all open campsites on Camp Swift. material is homogeneous across the landscape, these four sites should exhibit evidence of more intense exploitation than at the other seven sites. This poses a research question concerning raw material use that is beyond the scope of this survey project.

To evaluate the distances traveled during different time periods, we used the 12 campsites where diagnostic artifacts representing one time period were found. Seven Late Prehistoric and five Late Archaic sites comprised the sample (see Table 6-2). No clear differences are apparent between the two periods, with an average of 1,154 $m$ during the Late Archaic and an average of 1,200 $m$ during the Late Prehistoric (Figure 6-6).

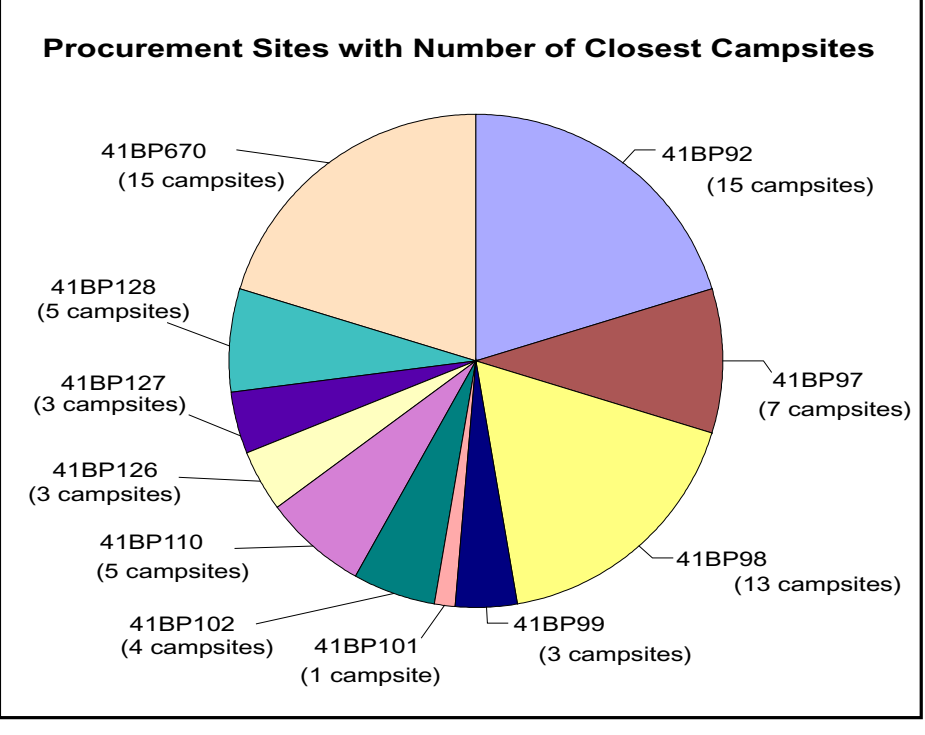

Figure 6-5. Pie chart showing the eleven lithic procurement sites plotted by the percent of nearest camp sites $(n=74)$.

\section{Depth and Formation of the Sandy Mantle}

One important research issue that must be investigated on any archaeological project is our understanding of the geological context of archaeological sites (Butzer 1982; Waters 1992). We hoped that the results obtained from the anticipated ca. 500 shovel tests to be excavated during this survey project would complement our current studies at Camp Swift, and add 


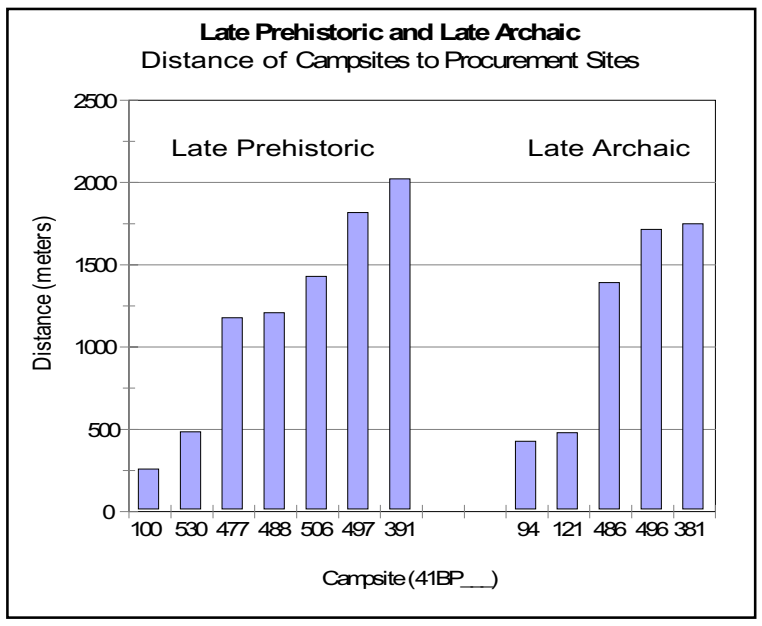

Figure 6-6. Late Prehistoric and Late Archaic campsites and their distances from the nearest lithic procurement site.

to both our understanding of how the sandy mantle was formed in east Central Texas, as well as the potential for intact archaeological sites existing within the mantle.
Depth of the Sandy Mantle

\section{Shovel Test Results}

During this survey we excavated 664 shovel tests and nine backhoe trenches over 307 acres of diverse topography and ecological settings. Table 6-4 presents the number and depths of shovel tests dug in various soil types, which in turn infer topographical settings. As may be expected because of the steeper slopes on which they are found, a single shovel test placed in Jedd stony soils was the shallowest. A common conception that archaeological sites are likely to be deeply buried in stream terraces (Axtell soils) is not borne out by the data, showing that soils are on average ca. $30-51 \mathrm{~cm}$ deep in those areas. The deepest soils encountered were on uplands, and in floodplains or bottomlands, suggesting that deeply buried sites are likely to be found in these two disparate settings.

Table 6-4. Depths of soil as determined by shovel tests.

\begin{tabular}{|c|c|c|c|c|}
\hline $\begin{array}{c}\text { No. } \\
\text { Shovel } \\
\text { Tests }\end{array}$ & $\begin{array}{c}\text { Average } \\
\text { Depth } \\
\text { (cm) }\end{array}$ & Soil Type & Setting & $\begin{array}{l}\text { No. Open } \\
\text { Campsites } \\
\text { Found }\end{array}$ \\
\hline 10 & 30.8 & $\begin{array}{l}\text { Axtell fine sandy loam, } 1 \\
\text { to } 5 \% \text { slopes }\end{array}$ & $\begin{array}{l}\text { Stream terraces and } \\
\text { uplands }\end{array}$ & \\
\hline 201 & 50.15 & $\begin{array}{l}\text { Axtell fine sandy loam, } 2 \\
\text { to } 5 \% \text { slopes, eroded }\end{array}$ & $\begin{array}{lll}\text { Stream terraces } & \text { and } \\
\text { uplands } & & \\
\end{array}$ & 4 \\
\hline 156 & 65.36 & $\begin{array}{l}\text { Demona loamy fine } \\
\text { sand, } 1 \text { to } 5 \% \text { slopes }\end{array}$ & $\begin{array}{l}\text { Ridgetops, sideslopes, } \\
\text { upland drainageways }\end{array}$ & 1 \\
\hline 1 & 28.00 & $\begin{array}{l}\text { Jedd stony soils, } 5 \text { to } \\
20 \% \text { slopes }\end{array}$ & $\begin{array}{l}\text { Small ridgetops, hilly } \\
\text { sideslopes }\end{array}$ & \\
\hline 181 & 74.88 & Patilo series & Uplands & 2 \\
\hline 102 & 70.37 & Sayers series & $\begin{array}{l}\text { Floodplains, } \\
\text { bottomlands }\end{array}$ & 1 \\
\hline 13 & 57.15 & $\begin{array}{l}\text { Tabor fine sandy loam, } 1 \\
\text { to } 3 \% \text { slopes }\end{array}$ & Broad uplands & \\
\hline
\end{tabular}




\section{Backhoe Trench Results}

\section{Geoarchaeology}

Nine backhoe trenches were excavated on the lower terrace of Big Sandy Creek (see Appendix B) to evaluate the nature of deposition and soil formation. No artifacts were observed in any of the trenches. A discussion of each backhoe trench follows, along with detailed sediment descriptions. In the field the sediments were divided into zones. A zone is a distinctive and homogeneous descriptive unit. Soil horizon designations were assigned in the field or later in the lab. Soil horizon and deposi- tional unit designations follow the Soil Survey Division Staff classifications (1993). Additionally we collected sediment samples from each trench for magnetic susceptibility and $\mathrm{pH}$ analyses and these data are presented and discussed.

\section{Backhoe Trench 1}

This backhoe trench was excavated into the left T1 terrace of Big Sandy Creek (Table 6-5). Two depositional units were observed. The uppermost unit occurs between $0-75 \mathrm{~cm}$ below the surface and the lower unit between 75-170+ $\mathrm{cm}$. Five zones were recognized in the uppermost unit

Table 6-5. Backhoe Trench 1, west wall profile.

\begin{tabular}{|c|c|c|c|}
\hline Zone & Depth (cm) & Horizon & Description \\
\hline 1 & $0-5$ & Ap & $\begin{array}{l}\text { Dark brown (10YR } 3 / 3) \text { loam, common rootlets, few roots, } \\
\text { leaf litter on surface, abundant decayed organic matter, } \\
\text { loose friable, lower boundary very abrupt and marked by } \\
\text { decomposing paper bag. }\end{array}$ \\
\hline 2 & $5-20$ & A1 & $\begin{array}{l}\text { Brown }(10 \text { YR } 4 / 3) \text { subangular blocky firm clay loam, } \\
\text { common worm burrows and casts, common rootlets few } \\
\text { large roots, clear smooth lower boundary. }\end{array}$ \\
\hline 3 & $20-25$ & $\mathrm{~A} 2$ & $\begin{array}{l}\text { Dark yellowish-brown (10YR 4/4) slightly lighter than } \\
\text { above, slightly firm clay loam, common rootlets, few roots; } \\
\text { abrupt smooth lower boundary (not an unconformity). }\end{array}$ \\
\hline 4 & $25-50$ & A3 & $\begin{array}{l}\text { Light olive-brown }(2.5 \mathrm{Y} 5 / 3) \text { friable sandy loam, common } \\
\text { rootlets, very few roots, clear smooth lower boundary. }\end{array}$ \\
\hline 5 & $50-75$ & B & $\begin{array}{l}\text { Light yellowish-brown }(2.5 \mathrm{Y} 5 / 4) \text { friable sandy loam, } \\
\text { common rootlets, few roots, clear smooth lower boundary. }\end{array}$ \\
\hline 6 & $75-105$ & 2B1 & $\begin{array}{l}\text { Olive-yellow ( } 2.5 \mathrm{Y} \text { 6/6) slightly firm, weak coarse } \\
\text { subangular blocky sandy loam, few rootlets, few roots, } \\
\text { firmness implies cementation but no CaCO3 present, slight } \\
\text { evidence of iron staining, clear smooth lower boundary. }\end{array}$ \\
\hline 7 & $105-170$ & $2 \mathrm{~B} 2$ & $\begin{array}{l}\text { Firm light yellowish-brown ( } 2.5 \mathrm{Y} 6 / 4) \text { to dark yellowish- } \\
\text { brown sandy loam, weak coarse subangular blocky, slightly } \\
\text { cemented and more firm than zone above, few roots, rare } \\
\text { rootlets, some darker } 4-5 \mathrm{~cm} \text { zones within zone } 7 \text {, lower } \\
\text { boundary not observed. }\end{array}$ \\
\hline
\end{tabular}


and consist of Ap, A1, A2, A3 and B horizons. The Ap horizon consists of a dark brown loam between $0-5 \mathrm{~cm}$ and a paper bag was discovered at the bottom of the zone. The A1-3 horizons range between $5-50 \mathrm{~cm}$ below the surface and grade from a brown clay loam to a light olive brown sandy loam. The A3 horizon grades down into a light yellowish-brown sandy loam that forms a B horizon. This B horizon sits unconformably on a $2 \mathrm{~B} 1$ horizon that marks the lower unit. The absence of an A horizon above Zone 6 capping the lower unit indicates truncation due to erosion. The lower unit changes from an olive yellow to a yellowish-brown sandy loam.

Soil susceptibility and $\mathrm{pH}$ were measured in sediment samples from the profile (Figure 6-7). Soil $\mathrm{pH}$ measures the acidity or alkalinity of soil. The $\mathrm{pH}$ scale goes from 0 to 14 . Soils with a $\mathrm{pH}$ level of 7 are neutral. From pH 7 to 0 soils are increasingly more acidic and from $\mathrm{pH} 7$ to 14 soils are increasingly more alkaline or basic. Soils tend to become acidic due to a series of processes. Rainwater leaches away basic ions (calcium, magnesium, potassium and sodium), carbon dioxide from decomposing organic matter and root respiration dissolves in soil water to form a weak organic acids. Strong organic and inorganic acids, such as nitric and sulfuric acid, are produced from decaying organic matter and the oxidation of ammonium and sulfur fertilizers. Strongly acid soils are usually the result of the action of these strong organic and inorganic acids.

Magnetic susceptibility of soils is a measure of the magnetic potential of the soil and in unbroken sequences these values tend to gradually change. Magnetic susceptibility is a measure of the ratio of the induced magnetization to an inducing field. It is expressed in Xm which is chi normalized by mass and presented in cgs units (Dalan and Banerjee 1998; Takac and Gose 1998). Measures are further modified by multiplying them by $10^{-6}$ (Takac and Gose 1998). Magnetic susceptibility can be used to define depositional breaks or unconformities, and peaks in human occupations.

Susceptibility values peak at $16.97\left(\mathrm{Xm}^{-6} 0^{-6}\right)$ in Zone 2 (A1 horizon) and then decline below this value. There is not a great deal of change between the depositional units (Zones 5-6), but a slight drop is visible. Even though soil acidity does not change a great deal, it reflects a reverse pattern with the highest $\mathrm{pH}$ level in the surface Ap horizon and the lowest in the A horizons. This may suggest that the A horizons have been leached to a minor degree.

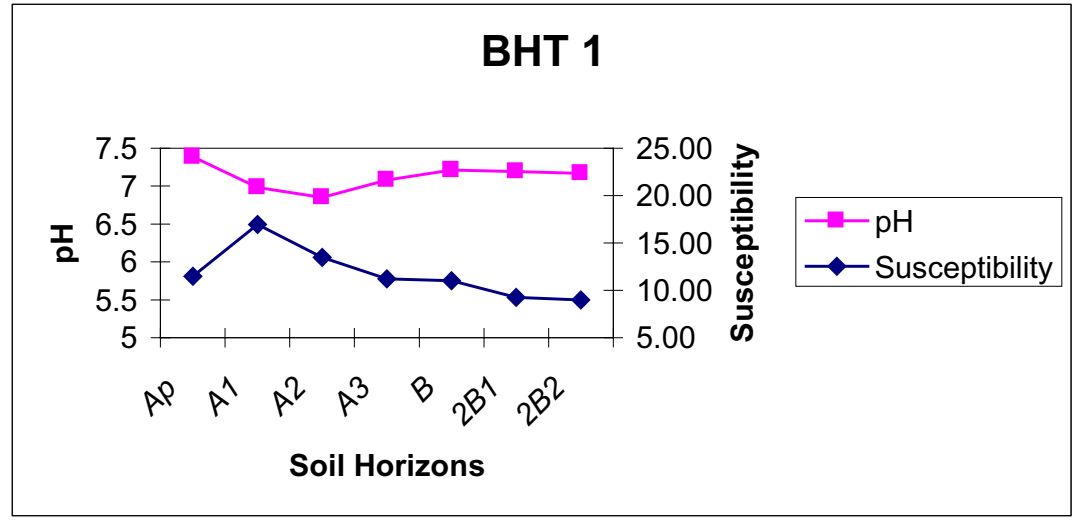

Figure 6-7. Magnetic susceptibility $\left(\mathrm{Xm} 10^{-6}\right)$ and $\mathrm{pH}$ values for Backhoe Trench 1.
The presence of visible soil structure in the $\mathrm{A} 1,2 \mathrm{~B} 1$ and 2B2 horizons implies that the sediments are intact. The mode of deposition, especially in the clay loam A1 and $\mathrm{A} 2$ horizons, appears to be primarily fluvial because of the fine grained sediments, but a colluvial contribution cannot be 
Table 6-6. Backhoe Trench 2, west wall profile.

\begin{tabular}{|c|c|c|c|}
\hline Zone & Depth (cm) & Horizon & Description \\
\hline 1 & $0-5$ & $\mathrm{O}$ & $\begin{array}{l}\text { Leaf litter, loose leaves \& twigs, decomposing with depth, } \\
\text { clear smooth lower boundary, very firm, abrupt lower } \\
\text { boundary. }\end{array}$ \\
\hline 2 & $5-19$ & A & $\begin{array}{l}\text { Dark grayish-brown ( } 10 \text { YR } 4 / 2) \text { very firm clay loam, fine } \\
\text { medium subangular blocky, common insect and earthworm } \\
\text { burrows and casts, common rootlets, clear smooth lower } \\
\text { boundary. }\end{array}$ \\
\hline 3 & $19-39$ & $\mathrm{AB}$ & $\begin{array}{l}\text { Brown (10YR 4/3) medium-fine moderate subangular } \\
\text { blocky clay loam, common earthworm burrows and casts, } \\
\text { few rootlets, few roots (some large), clear smooth lower } \\
\text { boundary. }\end{array}$ \\
\hline 4 & $39-60$ & B & $\begin{array}{l}\text { Dark yellowish-brown (10YR 4/4) slightly firm clayey } \\
\text { sandy loam, less clay than above, common rootlets and } \\
\text { roots, few pieces of scattered charcoal, clear smooth lower } \\
\text { boundary. }\end{array}$ \\
\hline 5 & $60-72$ & $2 \mathrm{~A}$ & $\begin{array}{l}\text { Light yellowish-brown }(2.5 \mathrm{Y} 6 / 4) \text { weak medium sub- } \\
\text { angular-blocky sandy loam, common rootlets, few roots, } \\
\text { scattered charcoal flecking, clear-smooth to wavy lower } \\
\text { boundary. }\end{array}$ \\
\hline 6 & $72-100$ & $2 \mathrm{~B}$ & $\begin{array}{l}\text { Light yellowish-brown ( } 2.5 \mathrm{Y} \text { 6/3) slightly firm medium } \\
\text { weak subangular to blocky sandy loam, few scattered } \\
\text { charcoal flecks, clear smooth lower boundary. }\end{array}$ \\
\hline 7 & $100-164$ & $2 \mathrm{C} 1$ & $\begin{array}{l}\text { Grayish-brown to light olive-brown to brown }(2.5 \mathrm{Y} 5 / 2 \text { to } \\
5 / 4 \text { ) friable sandy loam with two dark brown clayey sand } \\
\text { sub-horizons which appear to be depositional between from } \\
110-120 \text { and is not a lamellae, faint fine horizontal layering. }\end{array}$ \\
\hline 8 & $164-205$ & $2 \mathrm{C} 2$ & $\begin{array}{l}\text { Loose light yellowish-brown ( } 2.5 \mathrm{Y} 6 / 4) \text { sandy loam with } \\
\text { common faint medium gray to reddish-yellow mottles, } \\
\text { slight gleying, clear smooth lower boundary. }\end{array}$ \\
\hline 9 & $205-260$ & $2 \mathrm{G}$ & $\begin{array}{l}\text { Gray to light brownish-gray ( } 2.5 \mathrm{Y} 6 / 1 \text { to } 6 / 2 \text { ) weak, coarse, } \\
\text { sub-angular blocky sandy clay loam, common fine to } \\
\text { medium dark reddish-brown mottles, common rootlets, } \\
\text { reddish-brown mottles increase with depth. }\end{array}$ \\
\hline
\end{tabular}


ruled out.

\section{Backhoe Trench 2}

Backhoe Trench 2 was excavated in the terrace of Big Sandy Creek. Nine sediment zones were identified within two depositional units. The uppermost depositional unit displayed $\mathrm{O}, \mathrm{A}, \mathrm{AB}$ and $\mathrm{B}$ horizons in the upper $60 \mathrm{~cm}$. Between 60-260 $\mathrm{cm}$ below the surface were $2 \mathrm{~A}, 2 \mathrm{~B}, 2 \mathrm{C}$, $2 \mathrm{C} 2$ and $2 \mathrm{G}$ horizons (Table 6-6).

Leaflitter was documented in the upper $5 \mathrm{~cm}$. Between 5-19 $\mathrm{cm}$ there was a dark grayish-brown firm clay loam A horizon followed by a brown clay loam AB horizon from 19-39 cm. The lowest soil horizon in this sedimentary unit was a dark yellowish-brown clayey sandy loam B horizon. The uppermost soil horizon (Zone 5) in the second depositional unit consists of a light yellowish brown sandy loam. This grades to a slightly darker yellowish-brown sandy loam 2B horizon between $72-100 \mathrm{~cm}$. Between $100-164 \mathrm{~cm}$ is a grayish-brown to brown sandy loam with 2 dark brown clayey sub-horizons. These appear to be depositional and not lamellae. This zone is a $2 \mathrm{C} 1$ horizon. A 2C2 horizon consisting of a light yellowish-brown sandy loam with gray to reddish-yellow mottles occurs between 164-205 $\mathrm{cm}$, and the lowermost zone between 205-260 consists of a gray to light brownish-gray sandy clay loam with dark reddish-brown mottles that increase down profile. This lowest zone is gleyed.

Soil susceptibility values in the uppermost unit are highest in the $\mathrm{AB}$ horizon and then decline in the B horizon (Figure 6-8). In

\section{BHT 2}

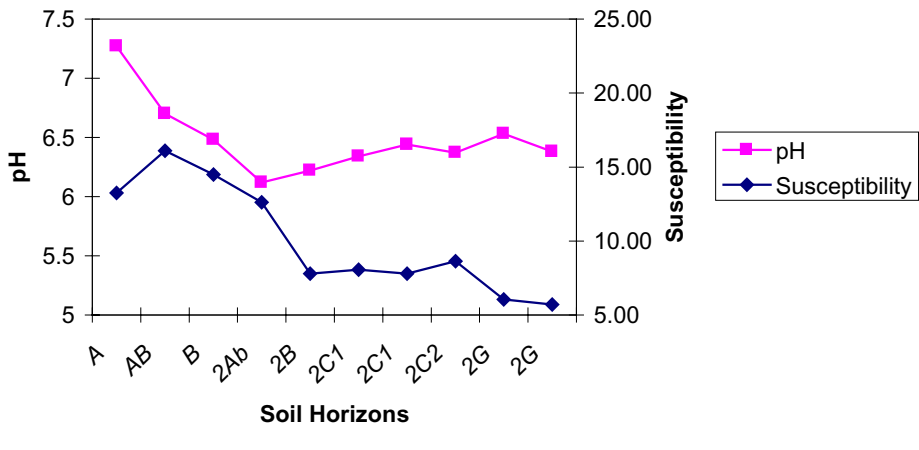

Figure 6-8. Magnetic susceptibility $\left(\mathrm{Xm}_{10} 0^{-6}\right)$ and $\mathrm{pH}$ values for Backhoe Trench 2.

the second depositional unit susceptibility values are highest in the $2 \mathrm{Ab}$ horizon and lowest in the gleyed (2G) horizon. The alkaline levels of the surface soil (A horizon) are the greatest and suggest a recent age or unleached condition for Unit 1. The more acidic $\mathrm{pH}$ levels measured in the $2 \mathrm{Ab}$ horizon probably imply greater leaching.

\section{Backhoe Trench 3}

Sediments in Backhoe Trench 3 consist of a single depositional unit with a surface A horizon between $0-23 \mathrm{~cm}$ consisting of a brown to dark brown clay loam (Table 6-7). Below the A horizon are three $\mathrm{B}$ horizons consisting of a dark yellowishbrown clay-silt loam to loam between $23-71 \mathrm{~cm}$.

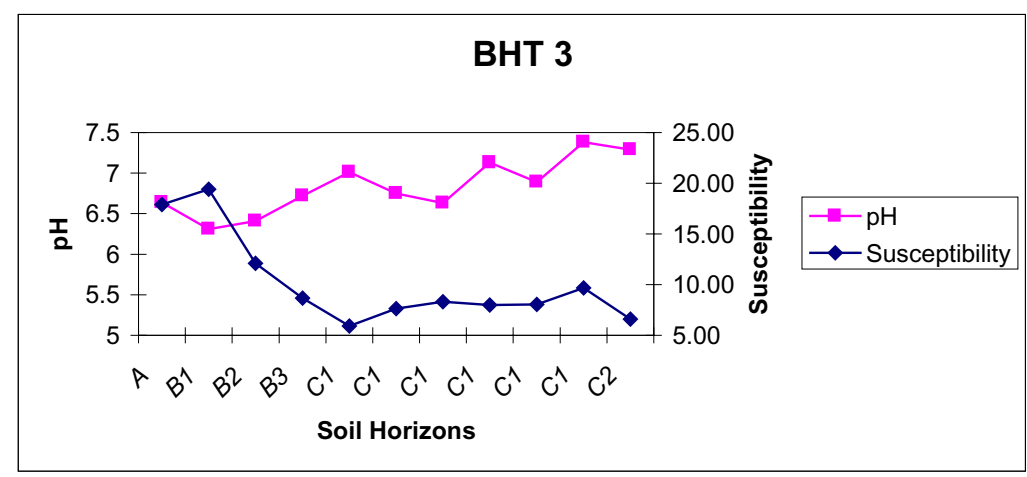

Figure 6-9. Magnetic susceptibility $\left(\mathrm{Xm}_{10^{-6}}\right)$ and $\mathrm{pH}$ values for Backhoe Trench 3. 
Table 6-7. Backhoe Trench 3, west wall profile.

\begin{tabular}{|c|c|c|c|}
\hline Zone & Depth (cm) & Horizon & Description \\
\hline 1 & $0-23$ & A & $\begin{array}{l}\text { Brown to dark-brown }(2.5 \mathrm{Y} 4 / 3) \text { fine to medium sub- } \\
\text { angular blocky firm clay loam, common roots and rootlets, } \\
\text { clear smooth lower boundary. }\end{array}$ \\
\hline 2 & $23-35$ & B1 & $\begin{array}{l}\text { Dark yellowish-brown }(2.5 \mathrm{Y} 5 / 4) \text { fine moderate sub- } \\
\text { angular blocky firm clay loam to silt loam, common roots } \\
\text { and rootlets, clear smooth lower boundary. }\end{array}$ \\
\hline 3 & $35-47$ & B2 & $\begin{array}{l}\text { Dark yellowish-brown ( } 2.5 \mathrm{Y} 5 / 4) \text { weak fine subangular } \\
\text { blocky slightly firm loam lighter than above, few roots and } \\
\text { rootlets, clear smooth lower boundary. }\end{array}$ \\
\hline 4 & $47-71$ & B3 & $\begin{array}{l}\text { Dark yellowish-brown }(2.5 \mathrm{Y} 5 / 4) \text { friable, fine, weak sub- } \\
\text { angular loam, few roots and rootlets, clear smooth lower } \\
\text { boundary. }\end{array}$ \\
\hline 5 & $71-178$ & $\mathrm{C} 1$ & $\begin{array}{l}\text { Light brown (2.5Y 6/4) friable sandy loam with alternating } \\
\text { brown slightly firm loam layers between } 96-110 \mathrm{~cm} \text { and } \\
149-156 \mathrm{~cm} \text { and a yellowish-brown }(2.5 \mathrm{Y} 5 / 6) \text { slightly firm } \\
\text { loam with weak, fine, subangular blocky small reddish- } \\
\text { brown mottles up to } 1 \mathrm{~cm} \text { in diameter between } 120-135 \mathrm{~cm} \text {, } \\
\text { brown root casts up to } 7 \mathrm{~cm} \text { in diameter, few roots and } \\
\text { rootlets, abrupt-smooth to wavy lower boundary. }\end{array}$ \\
\hline 6 & $178-210+$ & $\mathrm{C} 2$ & $\begin{array}{l}\text { Gray }(2.5 Y \text { Y } 6 / 1) \text { firm clay loam, with reddish mottles that } \\
\text { are distinct fine to medium. }\end{array}$ \\
\hline
\end{tabular}

Next, a C1 horizon consisting of a light brown sandy loam with alternating brown and yellowish- brown loam layers is between $71-178 \mathrm{~cm}$. The lowest soil horizon is a C2 horizon found between 178-210+ $\mathrm{cm}$ and consists of a gray clay loam.

The $\mathrm{pH}$ readings in the $\mathrm{C} 1$ horizon demonstrate the cyclic nature of deposition in this soil horizon, while the elevated susceptibility readings in the A and B1 horizons reflect the impact of elevated organic levels in the two uppermost soil horizons (Figure 6-9).

\section{Backhoe Trench 4}

The sediments in Backhoe Trench 4 (Table 68) reflect a single soil solum in a single depositional unit. The upper $13 \mathrm{~cm}$ are a brown sandy loam A horizon. Between 13-107 cm is a brown sandy loam $\mathrm{B} 1$ horizon that is followed by a light olive brown sand B2 horizon between 107-120 cm. From 120$190+\mathrm{cm}$ is a light yellowish-brown sand with clay lamellae ranging in thickness from 1-5 cm. This lower horizon is anE horizon. Soil susceptibility and $\mathrm{pH}$ levels show very little change, and suggest that a single unit is reflected (Figure 6-10). 
Table 6-8. Backhoe Trench 4, southwest wall profile.

\begin{tabular}{|c|c|c|c|}
\hline Zone & \multicolumn{3}{|c|}{ Depth $(\mathrm{cm})$ Horizon Description } \\
\hline 1 & $0-13$ & A & $\begin{array}{l}\text { Brown (10YR } 5 / 4) \text { friable sandy loam, common rootlets, no } \\
\text { roots, clear smooth lower boundary. }\end{array}$ \\
\hline 2 & $13-107$ & B1 & $\begin{array}{l}\text { Brown }(2.5 \mathrm{Y} 5 / 4) \text { very friable, massive, sandy loam, } \\
\text { common rootlets, clear smooth lower boundary. }\end{array}$ \\
\hline 3 & $107-120$ & B2 & $\begin{array}{l}\text { Light olive brown ( } 2.5 \mathrm{Y} 5 / 4) \text { friable sand, } 3 \text { soil lamellae } 1 \\
\text { mm in thickness and they are dark brown, clear smooth } \\
\text { lower boundary. }\end{array}$ \\
\hline 4 & $120-190+$ & $\mathrm{E}$ & $\begin{array}{l}\text { Light yellowish brown }(2.5 \mathrm{Y} 6 / 4) \text { sand w/regular lamellae } \\
\text { ranging from } 1 \mathrm{~mm} \text { to } 5 \mathrm{~cm} \text { in thickness, lower boundary } \\
\text { not observed. }\end{array}$ \\
\hline
\end{tabular}

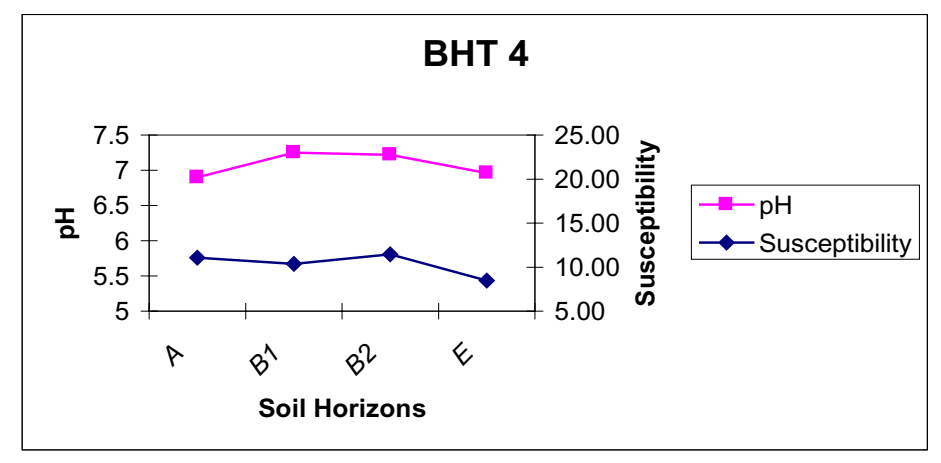

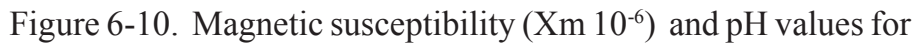
Backhoe Trench 4.

\section{Backhoe Trench 5}

The profile in Backhoe Trench 5 consists of three depositional units and six soil horizons. The uppermost unit was documented between $0-37 \mathrm{~cm}$ and consists of A and B soil horizons. A buried soil was observed between $37-70 \mathrm{~cm}$, but it sat unconformably on a series of $\mathrm{B}$ horizons between 70-290 cm (Table 6-9).
Soil $\mathrm{pH}$ levels show elevated values in the surface horizons perhaps implying the lack of leaching in these young deposits (Figure 6-11). The slightly lower $\mathrm{pH}$ value in the $2 \mathrm{Ab}$ horizon and the slightly elevated value in the $3 \mathrm{~B} 1$ horizon could be interpreted as a function of carbonate leaching. The susceptibility values do not provide much information due to the lack of variability. 
Table 6-9. Backhoe Trench 5, southeast wall profile.

\begin{tabular}{|cccc|}
\hline Zone & Depth (cm) & Horizon & Description \\
\hline 1 & $0-21$ & A & $\begin{array}{l}\text { Dark grayish-brown (10YR4/2) friable sandy loam, } \\
\text { common rootlets, clear smooth lower boundary. }\end{array}$ \\
3 & $21-37$ & B & $\begin{array}{l}\text { Brown (10YR 5/3) friable, sandy loam, plenty of common } \\
\text { rootlets and roots, clear sloping lower boundary. }\end{array}$ \\
4 & $37-70$ & 2Ab & $\begin{array}{l}\text { Light olive-brown (2.5Y 5/3) friable, sandy loam, lower } \\
\text { boundary is abrupt to smooth and sloping (unconformable } \\
\text { lower boundary). }\end{array}$ \\
5 & 30-118 & 3B1 & $\begin{array}{l}\text { Light-olive brown (2.5Y 5/4) medium-weak sub-angular } \\
\text { blocky slightly firm sandy loam. Few rootlets and few } \\
\text { insect burrows infilled with white sand from below. 3 } \\
\text { lamellae up to 1 cm thick and they are dark reddish-brown } \\
\text { clay loam, clear smooth lower boundary. }\end{array}$ \\
6 & 270-290 & 3Bt & $\begin{array}{l}\text { Light yellowish-brown (2.5Y 6/4) massive friable sandy } \\
\text { loam. Few (4) soil lamellae up to 3 cm thick, few rootlets, } \\
\text { no roots, clear smooth lower boundary. } \\
\text { Light yellowish-brown (2.5Y 6/3) clay loam, observed in } \\
\text { backhoe bucket but not described in situ due to depth of } \\
\text { trench. }\end{array}$ \\
\hline
\end{tabular}

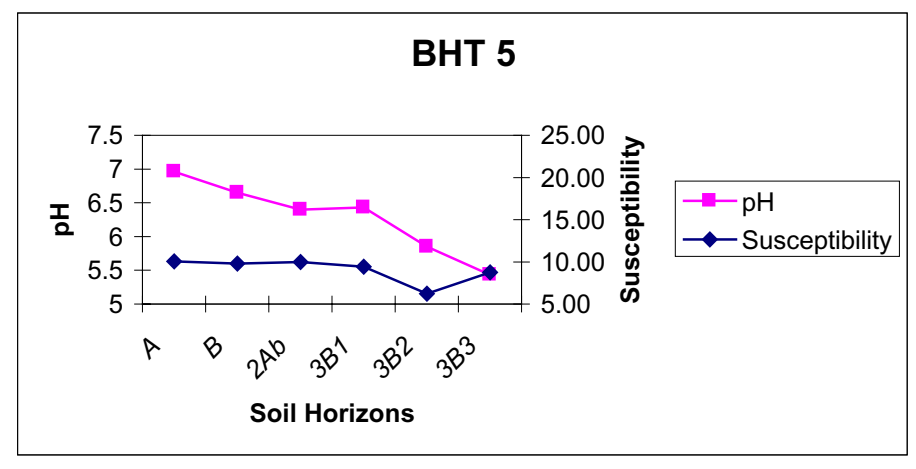

Figure 6-11. Magnetic susceptibility $\left(\mathrm{Xm} \mathrm{10}^{-6}\right)$ and $\mathrm{pH}$ values for Backhoe Trench 5. 
Table 6-10. Bachhoe Trench 6, north wall profile.

\section{Zone Depth Horizon Description}

\begin{tabular}{|llll|}
\hline 1 & $0-74$ & A & $\begin{array}{l}\text { Brown (2.5Y 5/3) loose, friable, massive sandy loam, } \\
\text { common rootlets decreasing down profile, few roots, clear } \\
\text { smooth lower boundary. }\end{array}$ \\
2 & $74-101 \quad$ B1 & $\begin{array}{l}\text { Light brown (2.5Y 5/4) loose sandy loam with three dark } \\
\text { brown to dark reddish-brown thin lamellae. Clear smooth } \\
\text { lower boundary. }\end{array}$ \\
& & \\
$101-180+\quad$ B2 & $\begin{array}{l}\text { Very pale brown (10YR 6/3 to 6/4) slightly firm sandy } \\
\text { loam, with at least seven lamellae up to 3 cm in thickness. } \\
\end{array}$ \\
& $\begin{array}{l}\text { Few rootlets almost no roots. Noticeably firmer than } \\
\text { above, no visible structure, massive. }\end{array}$ \\
\hline
\end{tabular}

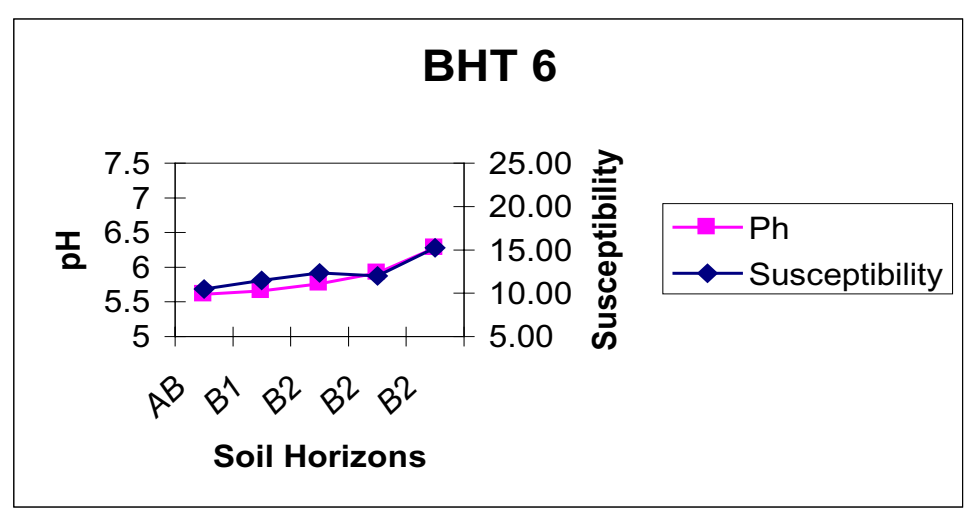

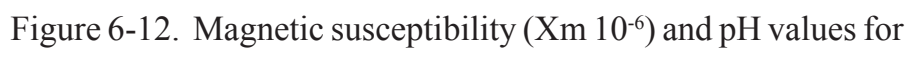
Backhoe Trench 6.

\section{Backhoe Trench 6}

Sediments in the $180 \mathrm{~cm}$ exposed in Backhoe Trench 6 demonstrate a simple single soil solum with an A horizon between 0-74 $\mathrm{cm}$ and two B horizons between 74-180+ $\mathrm{cm}$. The slight increase in soil $\mathrm{pH}$ and magnetic susceptibility suggests a limited degree of leaching in a single weathered depositional unit (Table 6-10, Figure 6-12).

\section{Backhoe Trench 7}

Sediments in Backhoe Trench 7 show a sole weathered soil solum in single depositional unit(Table 6-11). Five soil horizons ranging from a very dark grayish- brown clay loam A horizon to a light yellowish-brown sandy loam indicate a fair degree of soil formation. SoilpHlevels(Figure 6-13) also suggest a moderate degree of leaching. The susceptibility values indicate that the uppermost organic enriched soil horizons have greater magnetic susceptibility and this is probably due to the amount of organic matter.

\section{Backhoe Trench 8}

The sediments in Backhoe Trench 8 were divided into two depositional units (Table 6-12). The uppermost unit consists of an A horizon and a B horizon. The second depositional unit begins at 57 $\mathrm{cm}$ below the surface and consists of five soil horizons. A buried A horizon marks the top of this 


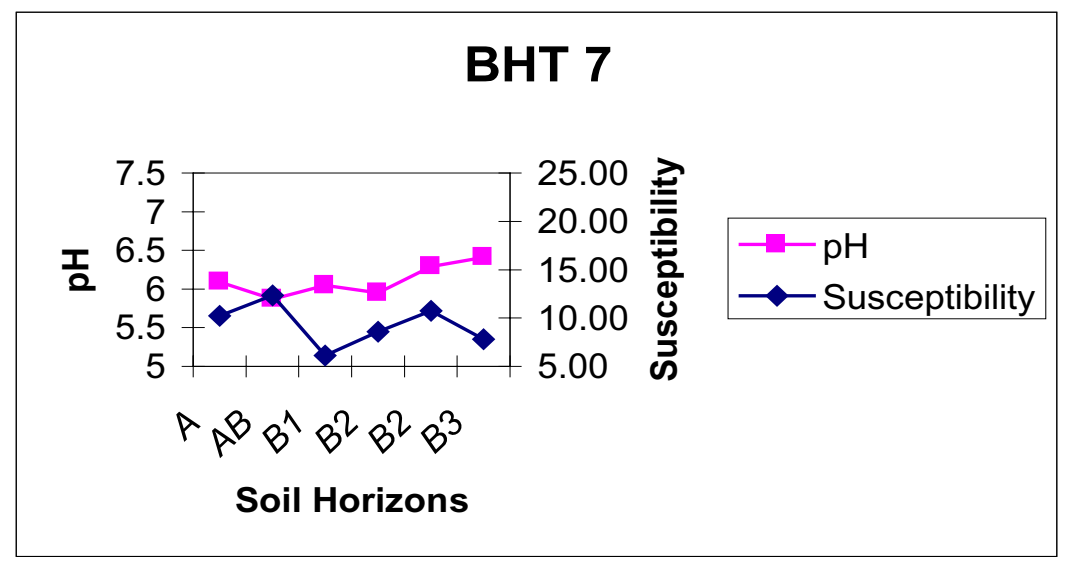

Figure 6-13. Magnetic susceptibility $\left(\mathrm{Xm} \mathrm{10}^{-6}\right)$ and $\mathrm{pH}$ values for Backhoe Trench 7.

unit. Leaching has formed an E horizon below this between $66-82 \mathrm{~cm}$. Following the E horizon are two $\mathrm{B}$ horizons and $\mathrm{a} \mathrm{C}$ horizon.

Magnetic susceptibility values in Backhoe
Trench 8 clearly show the elevated values due to organic enrichment found in the two A soilhorizons. Soil pH values are less distinct, however the lower values in the $2 \mathrm{Ab}$ horizon are probably due to carbonate leaching from thatzone (Figure 6-14).

\section{Backhoe Trench 9}

The sediments in Backhoe Trench 9 are divided into four depositional units and eight soil horizons (Table 6-13). A horizons are found between 1-7 cm, 25-33 $\mathrm{cm}, 69-93 \mathrm{~cm}$, and $120-140 \mathrm{~cm}$. Each marks the top of a depositional unit. The soil susceptibility values are surprisingly low at the surface, but jump in the

Table 6-11. Backhoe Trench 7, northeast wall profile.

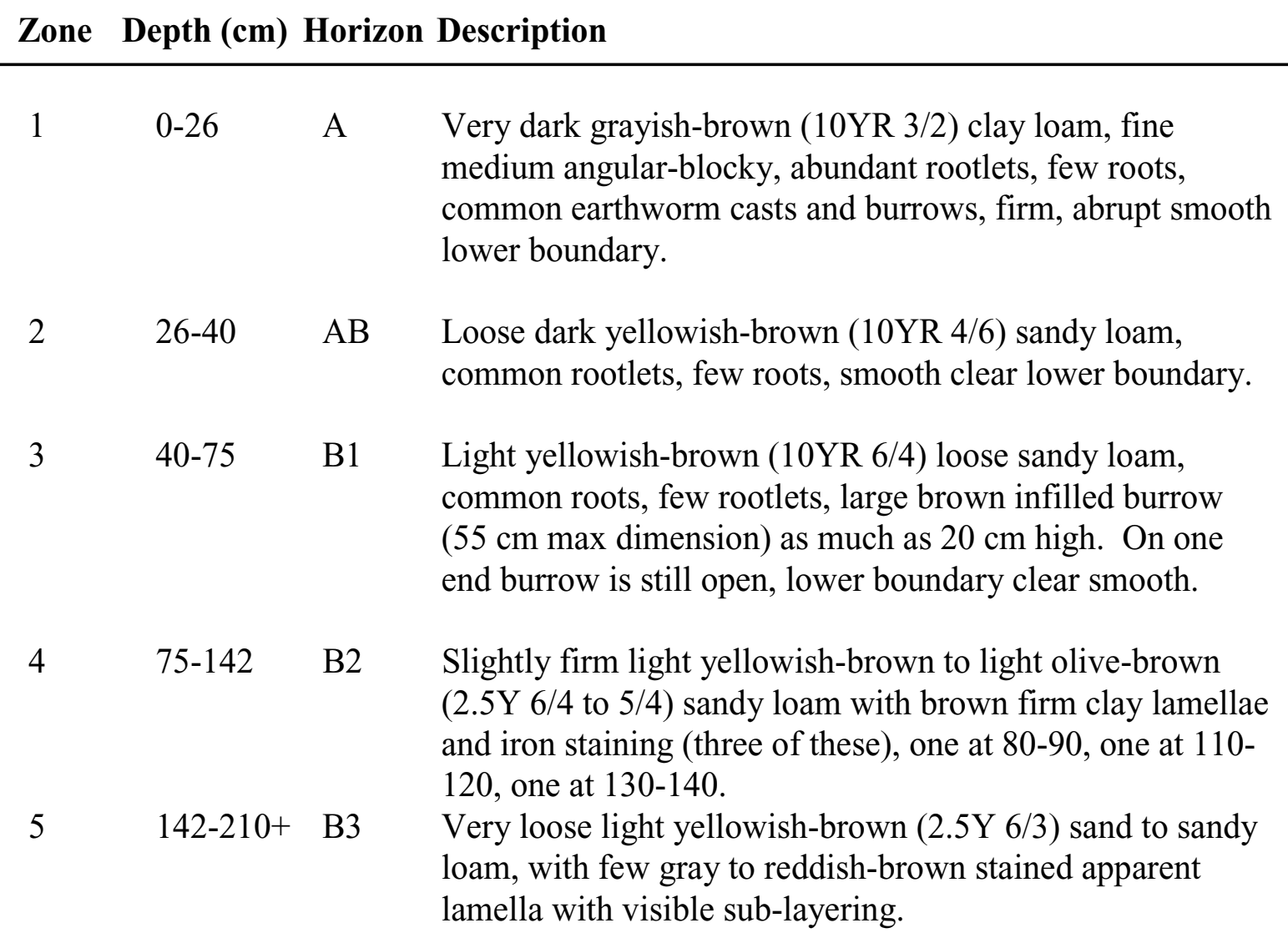




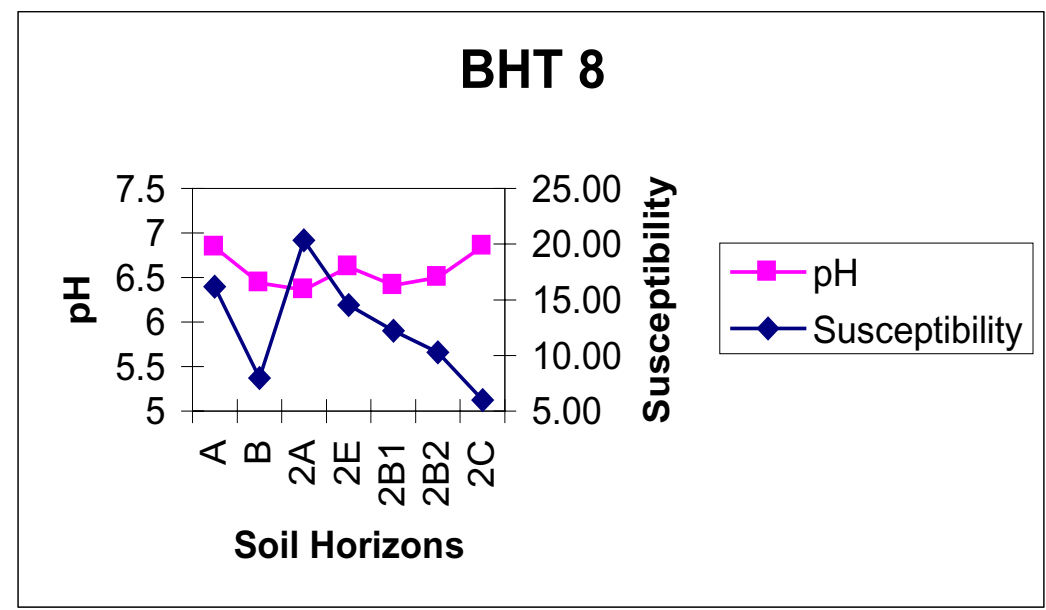

Figure 6-14. Magnetic susceptibility $\left(\mathrm{Xm}_{10}^{-6}\right)$ and $\mathrm{pH}$ values for Backhoe Trench 8 third depositional unit. Soil pH values are also surprisingly low in the uppermost soil horizons (Figure 6-15).

Conclusions

The sediments described in the nine backhoe trenches illustrate the nature of sedimentation adjacent to small streams at Camp Swift. Without additional chronological information, the degree of soil weathering suggests that the age of these deposits is not great and probably limited to

Table 6-12. Backhoe Trench 8, southeast wall profile

\begin{tabular}{|c|c|c|c|}
\hline Zone & Depth (cm) & Horizon & Description \\
\hline 1 & $0-36$ & A & $\begin{array}{l}\text { Dark yellowish-brown }(10 Y R 4 / 4) \text { firm clay/loam with fine } \\
\text { moderate sub-angular blocky structure. Clear smooth lower } \\
\text { boundary, common rootlets and roots. }\end{array}$ \\
\hline 2 & $36-57$ & B & $\begin{array}{l}\text { Dark yellowish-brown (10YR 4/6) slightly firm sandy loam } \\
\text { few roots and rootlets, no structure few charcoal flecks, } \\
\text { abrupt irregular but flat lower boundary. }\end{array}$ \\
\hline 3 & $57-66$ & $2 \mathrm{Ab}$ & $\begin{array}{l}\text { Dark yellowish-brown }(10 \mathrm{YR} 4 / 4) \text { firm clay loam, few } \\
\text { roots and rootlets. Clear to abrupt wavy to irregular lower } \\
\text { boundary. }\end{array}$ \\
\hline 4 & $66-82$ & $2 \mathrm{E}$ & $\begin{array}{l}\text { Yellowish-brown (10YR 5/4) friable sandy loam rare roots, } \\
\text { smooth to irregular flat lower boundary. }\end{array}$ \\
\hline 5 & $82-95$ & 2B1 & $\begin{array}{l}\text { Yellowish-brown (10YR 5/6) firm loam rare roots, weak } \\
\text { medium sub-angular blocky structure, clear smooth lower } \\
\text { boundary. }\end{array}$ \\
\hline 6 & $95-123$ & $2 \mathrm{~B} 2$ & $\begin{array}{l}\text { Firm very weak medium, sub-angular blocky light olive- } \\
\text { brown }(2.5 \mathrm{Y} 5 / 3) \text { sandy loam, almost no roots, gradual } \\
\text { smooth lower boundary. }\end{array}$ \\
\hline 7 & $123-190+$ & $2 \mathrm{C}$ & $\begin{array}{l}\text { Loose, coarse very pale brown (10YR } 7 / 3) \text { sand, lower } \\
\text { boundary not observed. }\end{array}$ \\
\hline
\end{tabular}




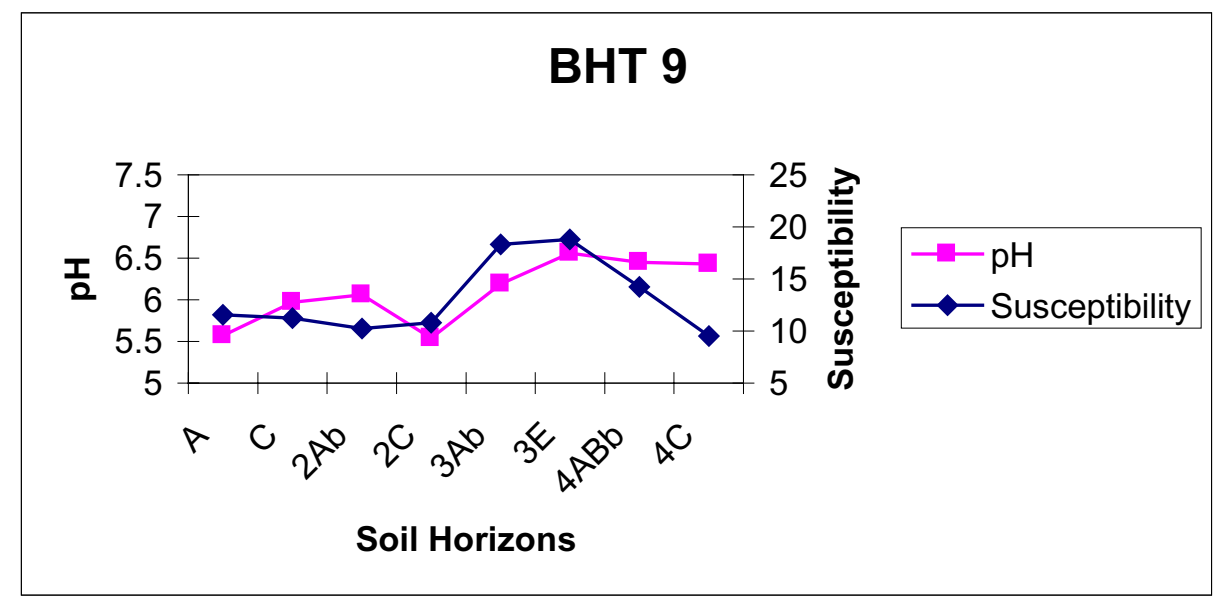

Figure 6-15. Magnetic susceptibility $\left(\mathrm{Xm} \mathrm{10}^{-6}\right)$ and $\mathrm{pH}$ values for Backhoe Trench 9.

Table 6-13. Backhoe Trench 9, southeast wall profile

\begin{tabular}{|c|c|c|c|}
\hline Zone & Depth (cm) & Horizon & Description \\
\hline 1 & $1-7$ & A & $\begin{array}{l}\text { Dark grayish brown (10YR 4/2) loose sandy clay loam with } \\
\text { abundant loose decomposing organic matter, a very thin } \\
\text { layer of leaf litter on the surface, abrupt smooth boundary. }\end{array}$ \\
\hline 2 & $7-25$ & $\mathrm{C}$ & $\begin{array}{l}\text { Yellowish brown (10YR 5/4) sandy loam with abundant } \\
\text { rootlets few roots no observable structure clear smooth } \\
\text { lower boundary. }\end{array}$ \\
\hline 3 & $25-33$ & $2 \mathrm{Ab}$ & $\begin{array}{l}\text { Yellowish brown (10YR } 5 / 4) \text { sandy clay loam common } \\
\text { rootlets no roots evidence of insect burrowing with light } \\
\text { filled burrows, thin deposited clayey layer, clear smooth } \\
\text { lower boundary. }\end{array}$ \\
\hline 4 & $33-69$ & $2 \mathrm{C}$ & $\begin{array}{l}\text { Light olive brown }(2.5 \mathrm{Y} 5 / 4) \text { sandy loam common rootlets } \\
\text { few roots, few rodent burrows, clear smooth lower } \\
\text { boundary. }\end{array}$ \\
\hline 5 & $69-93$ & $3 \mathrm{Ab}$ & $\begin{array}{l}\text { Light olive brown ( } 2.5 \mathrm{Y} 5 / 3) \text { sandy loam few filled insect } \\
\text { burrows few charcoal flecks, few roots and rootlets, clear } \\
\text { smooth lower boundary. }\end{array}$ \\
\hline 6 & $93-120$ & $3 \mathrm{E}$ & $\begin{array}{l}\text { Pale yellow ( } 2.5 \mathrm{Y} 7 / 4) \text { coarse sandy loam clear smooth } \\
\text { lower boundary. }\end{array}$ \\
\hline 7 & $120-140$ & $4 \mathrm{ABb}$ & $\begin{array}{l}\text { Light yellowish brown }(2.5 \mathrm{Y} 6 / 4) \text { sandy loam few roots no } \\
\text { structure, clear smooth lower boundary. }\end{array}$ \\
\hline 8 & $140-170+$ & $4 \mathrm{C}$ & Loose friable light yellowish brown ( $2.5 \mathrm{Y}$ 6/3) sandy loam. \\
\hline
\end{tabular}


the Late Holocene. The number of depositional units is not an indication of age but rather an indication of stream erosion and renewed deposition in the nature of rapid cut and fill sequences.

\section{Section II: Historic Issues}

\section{Historic Spatial Relationships}

The archaeological and archival investigations of these historic sites help clarify the spatial relationships of early Euro-American farming, ranching, and industrial activities in Bastrop County. Previous historical investigations have shown that settlements were established by the $1850 \mathrm{~s}$. This inventory provides additional insights into the evolution of settlement patterns in the Camp Swift area through the beginning of WWII.

\section{HistoricEconomy}

Within a few decades after the first land grants were obtained for the Camp Swift area, small communities and towns developed in the immediate and nearby areas. Among those were the Oak Hill, Dogwood, and Wayside communities, and the towns of Elgin, McDade, and Sayersville (Table 6-14). Little is known about the Wayside or Dogwood communities. Oak Hill, on the other hand, was evidently the earliest community and at one point had a multipurpose facility which served as a school and meeting place for church congregations (Smyrl 2003).

Nearly all historic structures were destroyed when Camp Swift was created, thus making an interpretation of architecture based upon remnants problematic at best. Therefore, evidence obtained by careful documentation of structural remains should not be used in an attempt to infer the probable economic scale of the occupants. Very little has been discovered in the categories of ceramics, glass, and metal that would suggest an anomaly in economic and class structure among a generally rural, middle and lower income farming community. However, by comparing the increases in housing and community development with the surrounding area, we are able to surmise a comparable standard of living. As the population and economy of Bastrop County changed, so did the makeup of the area that is now Camp Swift.

Skelton and Freeman (1979) have suggested that several more farmsteads were present at Camp Swift, but these have not been discovered by past surveys; nevertheless, for this analysis we use the 48 known homesteads out of a total of 90 historic components (Table 6-15). We reviewed the previous survey results to determine the distributions of temporally diagnostic artifacts for the historic farmsteads. By doing so, we were able to estimate the number of components by decade from 1850 to 1930 for the entire 11,500 acres of Camp Swift (Figure 6-16). These data were used to estimate the potential average size of farmstead in Camp Swift by decade. Based upon diagnostic artifacts found at the historic farmsteads, Figure 616 provides a relative estimate of the decreasing

Table 6-14. Early developments in the Camp Swift area.

\begin{tabular}{|l|c|c|c|c|}
\hline & Elgin & McDade & Oak Hill & Sayersville \\
\hline Established & 1871 & 1869 & 1849 & 1886 \\
\hline $1^{\text {st }}$ Post Office & 1873 & 1873 & & 1889 \\
\hline $1^{\text {st }}$ School & Ca. 1873 & 1874 & Pre-1879 & Ca. 1911 \\
\hline $1^{\text {st }}$ Church & & Pre-1873 & Pre-1879 & Pre-1911 \\
\hline
\end{tabular}


Table 6-15. Historic component types on Camp Swift.

\begin{tabular}{|c|c|}
\hline 90 Historic Components & Number \\
\hline Houses (Farmsteads) & 48 \\
\hline Trash Scatters & 23 \\
\hline Corrals & 4 \\
\hline Wells & 4 \\
\hline Cemeteries & 3 \\
\hline Bridges & 2 \\
\hline House and Winery & 1 \\
\hline Mines and Residences & 1 \\
\hline Stock Tank & 1 \\
\hline Isolated Grave & 1 \\
\hline School & 1 \\
\hline Outbuilding and Dam & 1 \\
\hline Total & $\mathbf{9 0}$ \\
\hline
\end{tabular}

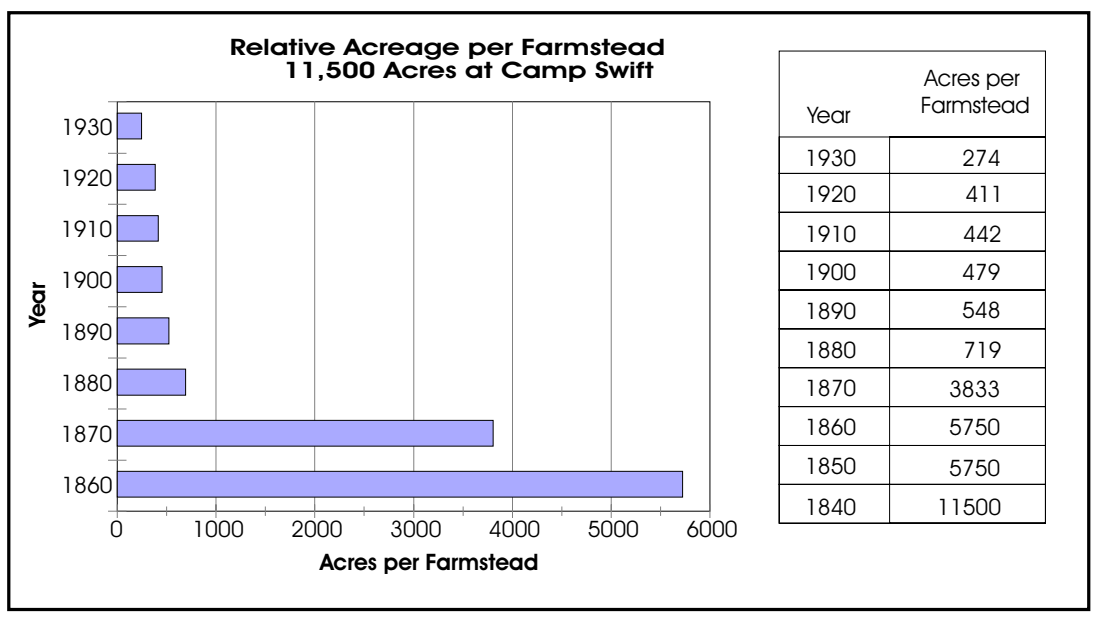

Figure 6-16. Decreasing acreage of farmsteads on Camp Swift.
Texas. Following the War, returning soldiers and freed slaves sought new lands. Notably, over the 40-year period between 1880 and 1920, the population of Bastrop County increased nearly 242 percent. During this same time period, as seen in Table 6-16, noteworthy events that affected the development of Camp Swift lands included the opening and closing of mines, a flourishing brick industry, more stores, newssize of farmsteads within the current 11,500-acre Camp Swift configuration.

Based upon this limited archaeological data alone, it appears by 1880 , the area experienced a burst of settlement compared to the previous decades. Undoubtedly, the advent of the Civil War stifled settlement here just as it did throughout papers, new church organizations, new schools, and practicing professionals.

In general, populations in the surrounding communities and Bastrop County declined just prior to 1920 and 1940. Primary causes were likely human losses and hardships endured during and immediately following WWI and the Great Depression. 
Table 6-16. Developments on Camp Swift relative to the surrounding area.

\begin{tabular}{|c|c|c|c|c|c|c|}
\hline & Bastop Co. & Oak Hill & McDade & Elgin & Sayersville & \\
\hline Year & Census & Census & Census & Census & Census & Noteworthy Events Affecting Camp Swift Residents \\
\hline 1849 & & & & & & Beginning of Oak Hill Community \\
\hline & & & & & & \\
\hline 1860 & 7,006 & & & & & 596 farms in Bastrop County \\
\hline 1861 & & & & & & Civil War: 1861-1865 \\
\hline 1868 & & & & & & Earliest marked grave in Oak Hill Cemetery \\
\hline 1869 & & & & & & McDade established \\
\hline & & & & & & \\
\hline 1870 & ca. 11000 & & & & & Railroad through McDade \\
\hline 1871 & & & & & & Houston \& Texas Railroad flagstop \\
\hline 1873 & & & & & & Post office, Baptist Sunday School in Elgin \\
\hline 1873 & & & & & & McDade incorporated, w/post office, cotton gin, Bapist church \\
\hline 1874 & & & & & & 1st school in McDade \\
\hline 1876 & & & & & & Antoine Aussiloux purchase 60 acres for winery in Camp Swift area \\
\hline 1879 & & & ca. 150 & ca. 400 & & New Facility for school and 3 church congregations in Oak Hill; \\
\hline & & & & & & Methodist Episcopal, Presbyterian, Christian \\
\hline & & & & & & Newspaper, gristmill, gin in Elgin \\
\hline & & & & & & \\
\hline 1881 & & & & & & Broom factory $\mathrm{w} / 10$ workers in McDade \\
\hline 1882 & & & & & & Baptist services began in Oak Hill; Methodist in Elgin \\
\hline 1882 & & & & & & Oak Hill now an established farming community, with cotton and corn \\
\hline & & & & & & as cash crops; vegetables and livestock for subsistence \\
\hline 1882 & & & & & & Earliest marked burial in New Hope Cemetery \\
\hline 1884 & & & & & & 1st brickmaking operation in Elgin, w/5 general stores, 2 druggists, \\
\hline & & & & & & 3 cotton gins, 1 saloon \\
\hline 1884 & & & & & & District school and still 1 church in Mcdade \\
\hline 1885 & & & & & & Antoine Aussiloux purchases 43 acres to construct dam across \\
\hline & & & & & & Spring Branch and irrigation ditch to his lower grape fields \\
\hline 1886 & & & & & & Taylor, Bastrop \& Houston Railroad (MK\&T) through Elgin, \\
\hline & & & & & & shipping point for cotton, wool, livestock \\
\hline 1886 & & & & & & Sayersville founded as cotton production center, then cordwood supplier \\
\hline 1889 & & & & & & Sayersville post office opened \\
\hline 1890 & & & ca. 250 & 831 & & Elgin - 2 hotels, broom factory, 2 doctors, 1 dentist, Courier Newspaper \\
\hline 1890 & & & & & & McDade Mentor Newspaper; McDade Pottery in operation; several \\
\hline & & & & & & coal mines in area \\
\hline 1896 & & & ca. 400 & & & 1 grade school, 3 churches, 2 blacksmiths, 2 milliners, 2 doctors in Mcdade \\
\hline & & & & & & \\
\hline 1900 & 26,845 & & & 1,258 & & 3,509 farms in Bastrop County \\
\hline 1903 & & & & & & Brickmaking industry in Elgin began in earnest \\
\hline 1905 & & & & & & 39 students, 1 teach in Oak Hill School \\
\hline 1907 & & & & & & Oak Hill School District formed \\
\hline & & & & & & \\
\hline 1914 & & & ca. 500 & & & Sayers lignite mine opened \\
\hline 1914 & & & & & & Texas Fire Brick workers lived in Sayersville; factory closed in 1914 \\
\hline 1916 & & & & & & 1 school, 1 church, several stores in Sayersville \\
\hline$\overline{1919}$ & & & & & & Texas Prohibition Amendment passed by Texas legislature, effectively \\
\hline & & & & & & putting Aussiloux's winemaking operation out of business \\
\hline & & & & & & \\
\hline 1920 & 26,649 & & & & & Natural gas replaced cordwood fuel in 1920s, detrimental to Sayersville \\
\hline 1920 & & & & & & 3,325 farms in Bastrop County \\
\hline 1922 & & & & & & Sayersville post office closed \\
\hline 1925 & & & ca. 600 & & & 4-block business district in McDade \\
\hline 1925 & & & & & & Antoine Aussiloux died \\
\hline 1928 & & & & & & Sayers lignite mine burned and closed \\
\hline 1929 & & & & & & Onset of the Great Depression \\
\hline & & & & & & \\
\hline 1930 & & & & & & McDade population declines in the 1930s \\
\hline 1933 & & & & & & 21st Amendment repealed Prohibition \\
\hline 1938 & & & & & & Rail passenger discontinued by this time in Sayersville \\
\hline 1940 & 21,610 & & & & ca. 50 & 2 business left in Sayersville; McDade Pottery closed in early 1940s \\
\hline 1940 & & & & & & 2,473 farms in Bastrop County \\
\hline 1942 & & & & & & Military takes over Camp Swift \\
\hline
\end{tabular}


Nevertheless, despite the growth and decline of towns and communities, Figure 6-16 indicates the sizes of farmsteads within the currently configured Camp Swift area decreased only slightly through the years 1880 through 1930 . The implica- tions are that the area remained a close-knit and hardy rural farming community, with farms established by 1880 remaining generally unaffected by local, national, and world events until the Great Depression. 


\section{Chapter 7}

\section{Summary AND Recommendations}

\section{David L. Nickels}

\section{Project Summary}

A pedestrian survey with shovel tests excavated in systematic intervals across 307 acres resulted in the discovery of 11 archeological sites and 9 isolated finds (see Table 5-2 and Chapter 5). The summary and recommendations for archaeological sites are discussed in this chapter; all nine isolated finds were assessed as not eligible for listing on the National Register of Historic Places. This project was undertaken to assist the TXARNG in meeting their requirements under Sections 106 and 110 of the NHPA. Establishing a full and complete inventory of prehistoric and historic archaeological sites is a critical step in meeting these requirements. Under these Sections, the protection of cultural resources is related to their eligibility for inclusion in the NRHP, which is in turn dependent on their significance as defined in 36 CFR Part 60.

\section{Project Results}

Of the 11 documented sites, seven have prehistoric components only, two sites have only a historic component, and two have both prehistoric and historic components. A total of 668 shovel tests and nine backhoe trenches were excavated within the project area. CAS personnel conducted a limited surface collection of unique items, collected selected historic items from shovel tests, and collected all prehistoric subsurface artifacts.

\section{Management Considerations - Prehistoric Components}

The purpose of this survey project was to provide the AGTX with a more accurate inventory of sites at Camp Swift. Our assessment of the research potential of these sites is based on the physical integrity of sites, the archaeological evidence present at a specific site, and the potential for significant research issues to be addressed by an investigation of the site. If deposits are significantly mixed, the potential of the recovered evidence to address the historic context issues discussed in Chapters 4 and 6 is significantly impeded.

Although we agree that the research potential of a site is viewed as a continuum; different levels of integrity are relevant for addressing different research issues. Nevertheless, sites with high physical integrity are more likely to yield data sets that are potentially capable of addressing a wider variety of research issues. The surface assemblages on eroded sediments are deflated, and generally represent palimpsests in secondary contexts. As such their research potential is considered minimal. However, in many cases, it appears there may be intact deposits below the surface. Therefore, we rely primarily on the results obtained from shovel testing to assess the physical integrity and research potential of each site. Sites were judged based on the following criteria: 
High potential: High integrity sites. Sites upon which shovel test results have indicated a pattern of stratified deposits, have potentially buried, intact deposits and/or datable features, and otherwise have the potential to address the research issues discussed in Chapters 4 and 6.

Moderate potential: Potentially high integrity sites. Sites upon which shovel tests results have not clearly demonstrated high integrity, but with further testing could yield buried, intact deposits and/or datable features, and otherwise have the potential to address the research issues discussed in Chapters 4 and 6.

Minimal potential: Little or no integrity sites. Sites upon which shovel testing results have produced no evidence of intact deposits, and/or have otherwise been disturbed so that there is little or no potential for providing credible information.

As the current project involved only limited excavation of shovel tests, recommendations required to be made by CAS according to the survey contract were as follows: 1) Eligible for the NRHP, 2) Not eligible for the NRHP, or 3 ) Requires further investigation beyond the scope of the inventory survey.

\section{Prehistoric Site Recommendations}

Phase II test excavation investigations are recommended on five prehistoric sites. The work plan for these sites should be structured to accommodate levels of effort which will provide sufficient information to determine whether or not sites are intact, and if sites appear to be intact, additional work should be sufficient to determine NRHP eligibility. Table 7-1 lists the five prehistoric component sites that need additional excavation units and/ or backhoe trenching to determine their integrity.

A probable buried hearth feature was located at 41BP665 during shovel testing. In this case, we recommend a 1-x-1-m excavation unit be used to further investigate this feature. We also recommend backhoe trenching be employed to search for additional features.

At 41BP667, the soils are shallow, and we observed fire-cracked rock (possibly hearths), a stone tool, and chipped debitage on the back dirt of a shallow trench. Therefore, we do not recommend backhoe trenching as the most viable and prudent method for further investigating this site. We instead, recommend that three 1-x-1-m excavation units excavated at 41BP667 will be sufficient to evaluate its integrity.

Otherwise, we recommend backhoe trenches as a primary investigation method on the remaining three sites, followed by hand excavation of units in locations of features identified during trenching operations. Specifically, backhoe trenching should be conducted to better assess the integrity of sites and buried components. Backhoe trench locations should be selected to sample areas likely to contain intact features as indicated by artifact density maps and positive shovel tests. If features are discovered, 1-x-1-m excavation units should be placed over them and excavated in order to help determine site eligibility.

Although the exact number of trenches dug on any given site should be determined by the project archaeologist in the field, based on shovel test excavations we are able to provide an estimate of the appropriate number to be placed at each site (see Table 7-1). Enough trenches should be dug to verify that either there are no intact deposits on the 
site that warrant test excavations, or that there appear to be intact deposits that warrant controlled excavation. In the latter case, enough information should be collected to allow the formulation of a data recovery plan.

Phase II excavation units should be dug after backhoe trenches have been completed. These controlled excavations should be directed toward investigation of cultural features or artifact concentrations. In the event that a cultural feature is clearly observed in a backhoe trench, the project archaeologist should open up a hand-excavated unit to investigate the feature.

NRHP eligibility is contingent upon the ability of a site to yield whole, significant, and credible information from high integrity contexts. In that regard, critical review should be made of the contextual presence or absence of well-preserved faunal, botanical, and charcoal remains, the presence or absence of datable material, the presence or absence of diagnostic artifacts, the presence or absence of intact features, the association of other cultural debris, and the overall geoarchaeological assessment of the site. Although all of these attributes are uncommon in sandy mantle sites, a combination of at least some of these attributes is critical to an eligibile site evaluation.

Ageomorphologist/gearchaeologist should describe and intrepret the profiles of each backhoe trench. When appropriate, soil particle size analysis, radicarbon assays, magnetic susceptibility, and $\mathrm{pH}$ analysis should be conducted. These data could be used to support conclusions regarding the potential of any given location to yield intact archaeological materials. Soil particle analysis provides a basis for determining pedogenesis and depositional processes before, during, and after site formation.
Sequential radiocarbon ages may be necessary to corroborate the ages of archaeological deposits and sediment depositional sequences at the site. Soil magnetic susceptibility may be used to either identify or corroborate the presence of buried palaeosols and/or potential humanoccupation zones. Measurments for $\mathrm{pH}$ levels may corroborate the presence and areas of increased human activity.

\section{Moderate Integrity Site Components}

Although there are no prehistoric component sites that we can yet assess as possessing high integrity, there are five prehistoric site components we assess as demonstrating moderate integrity, and these are potentially capable of having high research potential; thus we believe further investigation beyond the scope of this inventory survey are required before recommendations can be made regarding their eligibility for nomination to the NRHP. The minimum work required to further assess each site's potential for a Phase II test excavation program is presented in Table 7-1. Possible additional hand-excavated units may be required if potentially intact features are encountered.

\section{Minimum Integrity SiteComponents}

There are four prehistoric sites and/or distinct prehistoric component areas of sites we assess as having little or no integrity, likewise having minimal research potential, and thus these are recommended as not eligible for the NRHP. They are 41BP662, 41BP664, 41BP669 and 41BP670.

\section{Management Considerations - Historic Components}

Four historic components were documented during this project; their occupations ranging from the late 1800s through the early 1940s. Two are related to early farming activities in the Camp Swift 
Table 7-1. Recommendations for Phase II testing efforts for prehistoric site components assessed as having moderate integrity.

\begin{tabular}{|c|c|c|}
\hline Site & Backhoe Trenches & 1-x-1 m units \\
\hline 41BР665 & 3 & $\begin{array}{l}1 \text { plus additional units if } \\
\text { features discovered }\end{array}$ \\
\hline 41ВР666 & 9 & $\begin{array}{c}0, \text { unless features } \\
\text { discovered }\end{array}$ \\
\hline 41BР667 & 0 & $\begin{array}{l}3 \text { plus additional units if } \\
\text { features discovered }\end{array}$ \\
\hline 41BР671 & 4 & $\begin{array}{c}0, \text { unless features } \\
\text { discovered }\end{array}$ \\
\hline 41BР672 & 4 & $\begin{array}{l}0, \text { unless features } \\
\text { discovered }\end{array}$ \\
\hline
\end{tabular}

area. One is related to farming, but may also have the remains of a pottery kiln. The fourth has a dam and stone outbuilding that may be related to farming and/or a gravel quarry operation.

Department of the Interior Regulations 36 CFR 60 provide for National registration of historic properties that:

A) are associated with events that have made a significant contribution to the broad patterns of our history; or

B) are associated with the lives of persons significant in our past; or

C) embody the distinctive characteristics of a type, period, or method of construction, or that represent the work of a master, or that possess high artistic values, or that represent a significant and distinguishable entity whose components may lack individual distinction; or

D) have yielded, or may yield, information important in prehistory or history.

In addition, the integrity of individual properties should be evaluated in relation to like properties with a similar cultural theme, within the same geographical area, and generally within the same frame. It is within these contexts and with these criteria which we assess the integrity of the historic components

\section{Historic Site Recommendations}

Based on the management considerations discussed above, we assess 41BP663, 41BP668, and 41BP670 as ineligible for the NRHP, and recommended no further investigations.

At 41BP666, the farming operation appears to date to the first half of the twentieth century. However, the presence of kiln-glazed bricks and period stoneware suggest this may have been the site of local pottery production around the turn of the century. Such rural enterprises, somewhat uncommon, are poorly documented in the region and in the state of Texas. W believe that 41BP666 has moderate research potential. In order to properly determine whether or not a kiln could have existed at 41BP666, in-depth archival research and oral interviews with potential descendants should be conducted, along with an appropriate, noninvasive geomagnetic or conductivity survey of the area. 


\section{Summary}

We believe that the initial, Phase I survey and shovel tests has provided enough data to indicate that the prehistoric components at 41BP665, 41BP666, 41BP667, 41BP671, and41BP672 might have the potential to provide significant information to the prehistory of the region and Texas. Therefore, we recommend that these five prehistoric sites be further investigated with a combination of backhoe trenches to identify buried features and hand excavations to recovered more acurate data from these intact features in a Phase II test excavation program. We recommend a plan of avoidance be implemented by the AGTX in the interim in order to protect these five sites.

Conversely, investigations at 41BP662, 41BP664, 41BP669, and 41BP670 have indicated that the prehistoric components at these four sites possess very minimal integrity. They are therefore ineligible for nomination to the NRHP, no further work is recommended, and clearance should be granted to the AGTX to use these areas for training as necessary.

After conducting limited archival investigations and shovel testing on the historic components at sites 41BP663, 41BP668, and 41BP670, our recommendation is that these three sites possess little integrity and additional investigations are unwarranted. They are therefore ineligible for nomination to the NRHP, no further work is recommended, and clearance should be granted to the AGTX to use these areas for training as necessary.

The only historic component tested during this project that has the potential to contribute significant information to the history of the region and Texas is located at 41BP666. Therefore, until such a time when additional archival research and testing can be conducted, we recommend a plan of avoidance be implemented by the AGTX in order to protect this site. 


\section{References Cited}

Baker, F. E.

1979 Soil Survey of Bastrop County, Texas. U.S. Department of Agriculture, Soil Conservation Service, Washington, D. C.

Barber, E. A.

1976 Bicentennial Edition, Historical Statistics of the United States, Colonial Times to 1970. U.S. Department of Commerce, Bureau of Census, Washington, D.C.

Barnes, V. E.

1974 Geological Atlas of Texas, Austin Sheet. Bureau of Economic Geology, University of Texas, Austin.

Bastrop County. The Handbook of Texas online.

$2003<$ http://www.tsha.tsha.utexas.edu/handbook/online/articles/view/BB/hcb3.html $>$ [Accessed 9:05 AM, November 20, 2003].

Bastrop County Births

$2003<$ http://www.rootsweb.com/birth/IM002053.jpg [Accessed 11:54 AM, December 2, 2003].

Bastrop County Database

$2003<$ http://www.rootsweb.com/consolidated.htm [Accessed 11:37 AM, December 2, 2003].

Bastrop County Map

$2003<$ http://freepages.genealogy.rootsweb.com $\sim$ txtammy/bastrop/map/map.html $>$ [Accessed 12:24 PM, December 2, 2003].

Bastrop County Marriage Index

2003 Grooms Index A to E. $<$ http://www.rootsweb.com/marriage/AtoF.htm>

[Accessed11:45 AM, December 2, 2003].

Bement, L. C.

1989 Excavations at 41 BP19 the Kennedy Bluffs Site, Bastrop County, Texas. Contract Reports in Archaeology, Report Number 5, Texas State Department of Highways and Public Transportation, Highway Design Division, Austin. 
Big Sandy Creek. The Handbook of Texas online.

2003 http://www.tsha.utexas.edu/handbook/online/articles/view/BB/rbbda.html

[Accessed 10:37 AM, November 25, 2003]

Black, S.L.

1986 The Clemente and Herminia Hinojosa Site, 41JW8: a Toyah Horizon Campsite in Southern Texas. Special Report No 18. Center for Archaeological Research, The University of Texas at San Antonio, San Antonio.

1989a Central Texas plateau prairie. From the Gulf Coast to the Rio Grande: Human Adaptation in Central, South and Lower Pecos Texas, by T.R. Hester, S.L. Black, D.G. Steele, B.W. Olive, A.A. Fox, K.J. Reinhard, and L.C. Bement, pp. 17-38. Research Series No. 33. Arkansas Archeological Survey, Fayetteville.

1989b Environmental setting. From the Gulf Coast to the Rio Grande: Human Adaptation in the Central, South, and Lower Pecos Texas, by T.R. Hester, S.L. Black, D.G. Steele, B.W. Olive, A.A. Fox, K.J. Reinhard, and L.C. Bement, pp. 5-17. Research Series No. 33. Arkansas Archeological Survey, Fayetteville.

1989c South Texas plain. From the Gulf Coast to the Rio Grande: Human Adaptation in the Central, South, and Lower Pecos Texas, by T.R. Hester, S.L. Black, D.G. Steele, B.W. Olive, A.A. Fox, K.J. Reinhard, and L.C. Bement, pp. 39-62. Research Series No. 33. Arkansas Archaeological Survey, Fayetteville.

Black, S.L., and A.J. McGraw

1985 The Panther Springs Creek Site: Cultural Change and Continuity in the Upper Salado Creek Drainage, South-Central Texas. Archaeological Survey Report, No. 100. Center for Archaeological Research, The University of Texas at San Antonio.

Black, S.L., L.W. Ellis, D.G. Creel, and G.T. Goode

1997 Hot Rock Cooking on the Greater Edwards Plateau: Four Burned Rock Midden Sites in West Central Texas (two volumes). Studies in Archeology 22. Texas Archeological Research Laboratory, The University of Texas at Austin. Texas Department of Transportation Environmental Affairs Department, Archeology Studies Program, Report 2.

Blair, W. F.

1950 The Biotic Provinces of Texas. Texas Journal of Science 2(1):93-117.

Bousman, C.B.

1998 Paleoenvironmental change in Central Texas: the palynological evidence. Plains Anthropologist (43)164:201219.

Bousman, C.B., B.W. Baker, and A.C. Kerr

2004 Paleoindian archeology in Texas. In: The prehistory of Texas, edited by Timothy Perttula, pp 15-97. Texas A\&M University Press, College Station.

Bousman, C.B., M.B. Collins, P. Goldberg, T. Stafford, J. Guy, B.W. Baker, D.G. Steele, M. Kay, G. Fredlund, P. Dering, S. Dial, V. Holliday, D. Wilson, P. Takac, R. Balinsky, and J.F. Powell

2002 The Paleoindian-Archaic transition: new evidence from Texas. Antiquity 76:980-990. 
Boyd, D.K.

1997 Caprock Canyonlands Archeology: A Synthesis of the Late Prehistory and History of Lake Alan Henry and the Texas Panhandle-Plains. Reports of Investigations, Number 110. 2 Vols. Prewitt \& Associates, Austin.

Brown, D.O.

1998 Late Holocene climates of North-Central Texas. Plains Anthropologist (43)164:157-172.

Brown, K.M.

1966 41BP55. University of Texas Archeological Society notes on file at the Texas Archeological Research Laboratory, The University of Texas, Austin.

1983 Archaeological Studies at the CPS Butler Lignite Prospect, Bastrop and Lee Counties, Texas 1983. Archaeological Survey Report, No. 140. Center for Archaeological Research, The University of Texas at San Antonio.

1987 Early occupation at Berger Bluff, Goliad County, Texas. Current Research in the Pleistocene 4:3-5.

Bruseth, J.E. and W.A. Martin

2001 OSL dating and sandy-mantle sites in East Texas. Current Archeology in Texas 3:1:12-17.

Buder, J.J.

2003 Sayersville, TX. http://www.tsha.utexas.edu/handbook/online/articles/view/SS/hrs19.html [Accessed Thu Jan 15 5:36:57 US/Central 2004].

Butzer, K.W.

1982 Archaeology as Human Ecology: Method and Theory for a Contextual Approach. Cambridge University Press, Cambridge.

Collins, M.B.

1975 Lithic technology as a means of processual inference. In Lithic Technology, edited by Earl Swanson, pp. 15-34. Mouton Publishers, The Hague.

1995 Forty years of archeology in Central Texas. Bulletin of the Texas Archeological Society 66:361-400.

2004 Archeology in Central Texas. In The Prehistory of Texas, edited by Timothy K. Perttula, pp. 101-126. Texas A\&M University Press, College Station, Texas.

Collins, M.B. (assembler and editor)

1998 Wilson-Leonard: An 11,000-year Archeological Record in Central Texas, Volumes 1 - 6. Studies in Archeology 31, Texas Archeological Research Laboratory, The University of Texas at Austin; Archeology Studies Program, Report 10, Texas Department of Transportation, Environmental Affairs Division, Austin.

Collins, M.B., G.L. Evans, T.N. Campbell, M.C. Winans, and C.E. Mears

1989 Clovis occupation at Kincaid Rockshelter. Current Research in the Pleistocene 6:3-5. 
Collins, M.B., C.B. Bousman, P. Goldberg, P.R. Takac, J.C. Guy, J.L. Lanata, T. W. Stafford, and V.T. Holliday 1993 The Paleoindian sequence at the Wilson-Leonard Site, Texas. Current Research in the Pleistocene 10:10-12.

Collins, M.B., W.A. Gose, and S. Shaw

1994 Preliminary geomorphological findings at Dust and nearby caves. Journal of Alabama Archaeology 40:35-56.

Collins, M.B., and K.M. Brown

2000 The Gault gisement: some preliminary observations. In Current Archeology in Texas 2(1):8-11.

Covey, C. (editor)

1961 Cabeza de Vaca's Adventures in the Unknown Interior of America. Collier Books, New York.

Creel, D.G.

1986 A Study of Prehistoric Burned Rock Middens in West Central Texas. Unpublished Ph.D. dissertation, The University of Arizona, Tucson.

1990 Excavations at 41TG91, Tom Green County, Texas. Texas State Department of Public Transportation, Highway Design Division, Publications in Archaeology Report No. 38. Austin.

Cutrer, T.W.

1985 The English Texans. The University of Texas Institute of Texas Cultures at San Antonio.

Dalan, R.A. and S.K. Banerjee

1998 Solving archaeological problems using techniques of soil magnetism. Geoarchaeology 13:1:3-36.

Davis, E.M.

1964 Investigations of C. J. McCormick Site near McDade, Bastrop County, Texas. Unpublished notes on file at Texas Archeological Research Laboratory, The University of Texas, Austin.

Dibble, D.S.

1976 Results of an Archeological Survey of Areas to be Affected by a Proposed Sanitary Landfill, Camp Swift Texas. Texas Archeological Survey Technical Bulletin No. 11, The University of Texas at Austin.

Dibble, D.S., and D. Lorrain

1968 Bonfire Shelter: A Stratified Bison Kill Site, Val Verde County, Texas. Miscellaneous Papers 1. Texas Memorial Museum, Austin.

Dillehay, T.D.

1974 Late Quaternary bison population changes on the Southern Plains. Plains Anthropologist 19(64): 180-196.

1979 An Archeological Reconnaissance of the Fayette Power Plant to Lytton Springs Transmission Line. Texas Archeological Survey Research Report 73, The University of Texas, Austin. 
Fawcett, W.B., Jr.

1975 An Archeological Survey of the Proposed Federal Youth Center, Bastrop County, Texas. Texas Archeological Survey Technical Bulletin No. 10, The University of Texas at Austin.

Fox, A.A., and D.E. Fox

1967 The Classen Rockshelter, 41BX23. Manuscript on file. Center for Archaeological Research, The University of Texas at San Antonio.

Fox, A.A., I.W. Cox, L. Highley, and D. Hafernik

1989 Archaeological and Historical Investigations at the Site of the New Bexar County Justice Center in Downtown San Antonio, Texas. Archaeological Survey Report, No. 184. Center for Archaeological Research, The University of Texas at San Antonio.

Frederick, C.D. and M.D. Bateman

2001 OSL dating and sandy-mantle sites in East Texas: a reply. Current Archeology in Texas 3:2:14-18.

Givens, R.D.

1968 On the peopling of America. Current Anthropology 9:219.

Goode, G.T.

1989 Archaeological testing and recommendations for the Kennedy Bluffs Site, 41BP19, in Bastrop County, Texas. Appendix II. In Excavations at 41BP19, the Kennedy Bluffs Site, Bastrop County, Texas by L.C. Bement. Contract reports in Archaeology, Report 5, Texas State Department of Highways and Public Transportation, Highway Design Division, Austin.

1991 Late Prehistoric burned rock middens in Central Texas, In The Burned Rock Middens of Texas: An Archaeological Symposium, edited by T.R. Hester, pp. 71-93. Studies in Archaeology 13. Texas Archeological Research Laboratory, The University of Texas at Austin.

Gose, W.A. and D.L. Nickels

2001 Archaeomagnetic and magnetic susceptibility analyses. In Test Excavations at the Culebra Creek Site, 41BX126, Bexar County, Texas, pp. 204-214, by D.L. Nickels, C.B. Bousman, J.D. Leach, and D.A. Cargill. Archaeological Survey Report, No. 265, Center for Archaeological Research, the University of Texas at San Antonio; Archeological Studies Program, Report 3, Environmental Affairs Division, Texas Department of Transportation, Austin.

Gould, F.W.

1975 Texas Plants - A Checklist and Ecological Summary. Bulletin MP-585:5-14. Texas Agricultural Experimentation Station, College Station.

Greer, G.H.

n.d. Manuscript on file, Georgianna H. Greer Collection, Center for Archaeological Research, The University of Texas at San Antonio.

1981 American Stonewares, The Art and Craft of Utilitarian Potters. Schiffer Publishing, Exton, England. 
Hall, G.D.

1981 Allens Creek: A Study in the Cultural Prehistory of the Brazos River Valley, Texas. Research Report 61. Texas Archeological Survey, The University of Texas at Austin.

1988 Prehistoric human food resource patches on the Texas Coastal Plain. Bulletin of the Texas Archeological Society 69:1-10.

Hall, G.D., S.L. Black, and C. Graves

1982 Archaeological Investigations at Choke Canyon Reservoir, South Texas: The Phase I Findings. Choke Canyon Series: Volume 5, Center for Archaeological Research, The University of Texas at San Antonio.

Harris, E.S.

1985 An Archaeological Study of the Timmeron Rockshelter (41HY95), Hays County, South Central Texas. Special Publication 4. Southern Texas Archaeological Association, San Antonio.

Heller, F., and M.E. Evans

1995 Loess magnetization. Reviews of Geophysics 33:211-240.

Henderson, J.

1978 Faunal analysis of site 41BX36, with data presented for 41BX377 and 41BX428. In The Fort Sam Houston Project: An Archaeological and Historical Assessment, edited by A. Gerstle, T.C. Kelly, and C. Assad, pp. 229-252. Archaeological Survey Report, No. 40. Center for Archaeological Research, The University of Texas at San Antonio.

Henry, D.O.

1989. Correlations between reduction strategies and settlements patterns. In: D.O. Henry and G.H. Odel (eds.), Alternative Approaches to Lithic Analysis. Archaeological Papers of the American Anthropological Association, Number 1, 139-155.

Hester, T.R.

1966 Daily log, Bastrop Archeological Survey. Copy on file at the Texas Archeological Research Laboratory, The University of Texas, Austin.

1995 Prehistory of South Texas. Bulletin of the Texas Archeological Society 66:427-459.

Holloway, R.G.

1988 Pollen Analysis of 41MI8, Mills County, Texas. Contribution 4. Laboratory of Quaternary Studies, Department of Anthropology, Eastern New Mexico State University, Portales.

Hudson, C.

1976 The Southeastern Indians. University of Tennessee Press, Knoxville.

Huebner, J.A.

1991 Late Prehistoric bison populations in Central and Southern Texas. Plains Anthropologist 36(137): 343-358. 
Hughes, J.T.

1991 Prehistoric cultural developments on the High Texas Plains. Bulletin of the Texas Archeological Society 60:1-55 (1989 volume published in 1991).

Hulbert, R.C., Jr.

1985 Vertebrate faunal remains. In The Panther Springs Creek Site: Cultural Change and Continuity within the Upper Salado Creek Watershed, South-Central Texas, edited by S. L. Black and A. J. McGraw, pp. 209-215. Archaeological Survey Report, No. 100. Center for Archaeological Research, The University of Texas at San Antonio.

Humphrey, J.D., and C.R. Ferring

1994 Stable isotopic evidence for latest Pleistocene and Holocene climatic change in North-Central Texas. Quaternary Research 41:200-213.

Ivey, J.E., and A.A. Fox

1981 Archaeological Survey and Testing at Ranchos de las Cabras, Wilson County, Texas. Archaeological Survey Report, No. 104. Center for Archaeological research, The University of Texas at San Antonio.

Jelks, E.B.

1953 Excavations at the Blum Rockshelter. Bulletin of the Texas Archeological Society, Vol. 24, pp. 189207.

1962 The Kyle Site: A Stratified Central Texas Aspect in Hill County, Texas. Archeology Series, No. 5. Department of Anthropology, The University of Texas, Austin.

Johnson, L., and G.T. Goode

1994 A new try at dating and characterizing Holocene climates, as well as archaeological periods, on the eastern Edwards Plateau. Bulletin of the Texas Archeological Society 65:1-51.

Johnson, E., and V.T. Holliday

1986 The Archaic record at Lubbock Lake. Current Trends in Southern Plains Archeology, edited by T. G. Baugh. Plains Anthropologist Memoir 22:7-54.

Johnson, L. Jr., D.A. Suhm, and C.D. Tunnell

1962 Salvage Archaeology of Canyon Reservoir: The Wunderlich, Footbridge, and Oblate Sites. Bulletin No. 5. Texas Memorial Museum, The University of Texas at Austin.

Judson, S, and M.E. Kauffman

1990 Physical Geology. Eighth edition, Prentice Hall, Englewood Cliffs, New Jersey.

Jurney, D.H.

1988 Cut and wire nails: function and temporal interpretations. In Historic Farming on the Hogwallow Prairies: Ethnoarchaeological Investigations of the Mountain Creek Area, North Central Texas, pp. 315-324. Joe Pool Archaeological Project, Volume II, complied by D.H. Jurney, S.A. Lebo, and M.M. Green. Archaeology Research Program, Institute for the Study of Earth and Man, Southern Methodist University, Dallas. 
Kelley, J.C.

1947a The Lehmann Rockshelter: a stratified site of the Toyah, Uvalde and Round Rock foci. Bulletin of the Texas Archeological and Paleontological Society 18:115-128.

1947b The cultural affiliations and chronological position of the Clear Fork Focus. American Antiquity 13(2):97-108.

Kelly, T.C.

1993 Preceramic projectile-point typology in Belize. Ancient Mesoamerica 4:205-227.

Kelly, T.C., and E. Roemer, Jr.

1981 Archaeological and Historical Investigations in Bastrop and Lee Counties, Texas. Archaeological Survey Report, No. 101, Center for Archaeological Research, The University of Texas at San Antonio.

Leach, J.D., and C.B. Bousman

2001 Cultural and secondary formation processes: on the dynamic accumulation of burned rock middens. In: Test Excavations at the Culebra Creek Site, 41BX126, Bexar County, Texas, by Nickels, D.L., C.B. Bousman, J.D. Leach, and D.A. Cargill, pp. 119-145. Archaeological Survey Report, No. 265, Center for Archaeological Research, The University of Texas at San Antonio. Archeology Studies Program, Report 3, Environmental Affairs Division, Texas Department of Transportation, Austin.

Leach, J.D., C.B. Bousman and D.L. Nickels

2005 Assigning context to artifacts in burned rock middens. Journal of Field Archaeology 30:201-203.

Leffler, J.J.

2001 The history of the Camp Swift area, 1830-1950. In An Archaeological Inventory of Camp Swift, Bastrop County, Texas, pp. 153-166, edited by B. Meissner. Archaeological Survey Report Number 316, Center for Archaeological Research, The University of Texas at San Antonio.

Leshley, C.M.

1994 Archeological Survey for Ammunition Storage Facilities at Camp Swift, Bastrop County, Texas. Unpublished Archeological Survey Report, Adjutant General's Department of Texas, Austin.

1996 Archeological Survey for the Proposed Army Aviation Support facility at the Camp Swift Military Reservation, Bastrop County, Texas. Unpublished Archeological Survey Report, Adjutant General's Department of Texas, Austin.

Lewis, D.R.

1978 Use of phosphate analysis for determining land use patterns. In Bulletin of the Texas Archeological Society 49:309-317.

Lim, B.G., F.B. Pearl, and S.W. Moss

2000 Cultural Resources Survey of US 290; SH 95 to One Mile East of FM 696, Bastrop County, Texas. Report of Investigations No. 1, prepared for the Texas Department of Transportation, Austin District by Quadrant Consultants, Inc., Houston. 
Lukowski, P.D.

1987 Archaeological Investigations at 41BX1, Bexar County, Texas. Archaeological Survey Report, No. 135. Center for Archaeological Research, The University of Texas at San Antonio.

Malone, J.

1968 Archeological Site Survey Work in Bastrop County. Report on file, Texas Archeological Research Laboratory, The University of Texas, Austin.

Marks, P.M.

2003a Elgin, Texas. The Handbook of Texas Online. http://www.tsha.utexas.edu/handbook/online/articles/ print/MM/hlm45.html [Accessed Thu Jan 16 11/01/43 US/Central 2004].

2003b McDade, Texas. The Handbook of Texas Online. http://www.tsha.utexas.edu/handbook/online/ articles/print/MM/hlm45.html [Accessed Thu Jan 15 5:33:35 US/Central 2004].

Martin, W.A., B.C. Yates, and G.J. Fritz

1988 Exploitation of subsistence resources within the Mountain Creek drainage. In Late Holocene Prehistory of the Mountain Creek Drainage, Joe Pool Lake Archaeological Project, Volume I, edited by D.E. Peter and D.E. McGregor. Archaeology Research Program, Southern Methodist University, Dallas.

Mauldin, R.P.

2001 Assessments and recommendations. In An Archaeological Inventory of Camp Swift, Bastrop County, Texas, pp. 175-186, edited by B. A. Meissner. Archaeological Survey Report Number 316, Center for Archaeological Research, The University of Texas at San Antonio.

2003a Development of burned rock middens at Camp Bowie. In Archaeological Testing to Determine the National Register Eligibility Status of 18 Prehistoric Sites on Camp Bowie, Brown County, Texas (2 volumes), pp. 175-196. Adjutant General's Department of Texas, Department of Facilities and Engineering, Environmental Branch, Austin, TX and Archaeological Survey Report, No. 334, Center for Archaeological Research, The University of Texas at San Antonio.

2003b Subsistence issues in Camp Bowie middens. In Archaeological Testing to Determine the National Register Eligibility Status of 18 Prehistoric Sites on Camp Bowie, Brown County, Texas (2 volumes), pp. 197-208. Adjutant General's Department of Texas, Department of Facilities and Engineering, Environmental Branch, Austin, TX and Archaeological Survey Report, No. 334, Center for Archaeological Research, The University of Texas at San Antonio.

Mauldin, R.P., and D.L. Nickels

2003 Chronological placement of Camp Bowie burned rock middens. In Archaeological Testing to Determine the National Register Eligibility Status of 18 Prehistoric Sites on Camp Bowie, Brown County, Texas (2 volumes), pp. 165-174. Adjutant General's Department of Texas, Department of Facilities and Engineering, Environmental Branch, Austin, TX and Archaeological Survey Report, No. 334, Center for Archaeological Research, The University of Texas at San Antonio.

McKern, W. C.

1939 The Midwestern Taxonomic Method as an aid to archaeological culture study. American Antiquity Vol. 4: 301-313

McKinney, W.W.

1981 Early Holocene adaptations in Central and Southern Texas:the problem of the Paleo-Indian-Archaic transition. Bulletin of the Texas Archeological Society 52:91-120. 
Meissner, B.A.

1991 Notes on the Excavation of 41BX952. Manuscript on file. Center for Archaeological Research, The University of Texas at San Antonio.

1993 Where the buffalo roam: archaeological evidence of bison populations in South and Central Texas. Manuscript on file. Center for Archaeological Research, The University of Texas at San Antonio.

Meissner, B.A. (editor)

2001 An Archaeological Inventory of Camp Swift, Bastrop County, Texas. Archaeological Survey Report Number 316, Center for Archaeological Research, The University of Texas at San Antonio.

Meltzer, D.J., and M.R. Bever

1995 Paleoindians of Texas: an update on the Texas Clovis fluted point survey. Bulletin of the Texas Archeological Society 66:47-81

Miller, G.L.

1991 A revised set of CC Index Values for classification and economic scaling of English ceramics from 1787 to 1880. Historical Archaeology 25(1):1-25.

1993 A user's guide to ceramic asssemblages, part four: some thoughts on classification of white earthenwares. Council for Northwest Historical Archaeology Newsletter, No. 26.

Monger, M.A.

1959 Mission Espititu Santo of Coastal Texas: An Example of Historic Site Archeology. Unpublished Master's Thesis, University of Texas, Austin.

Moore, B.

1977 Bastrop County, 1691-1900. Nortex Press, Wichita Falls, Texas.

Moore, D.

1987 Appendix II: additional archival investigations of seven historic sites within the CPS Butler Lignite Prospect, Bastrop and Lee Counties, Texas. Espey, Huston \& Associates, Austin.

Morris, W.

1970 The Wichita exchange; trade on Oklahoma's fur frontier, 1719-1812. Great Plains Journal (9)2:79-84. Great Plains Historical Association, Lawton, Oklahoma.

Munsey, C.

1970 The Illustrated Guide to Collecting Bottles. Hawthorn Books, Inc., New York.

Nash, M.A., R.F. Taylor, and E.A. Skokan

1995 A Cultural Resources Survey of the McNeil-Bastrop 138-Kv Transmission Line Rebuild Project, Bastrop and Travis Counties, Texas. Espey, Huston \& Associates, Austin.

Nash, M.A., D. Green, E. Baxter, and R. Brownlow

1996 Class III Cultural Resources Inventory and Biological Survey of 4 Wellpads and Access Road Routes, Camp Swift, Bastrop County, Texas. Document No. 960561, EH\&A Job No. 17293 Espey, Huston \& Associates, Inc., Engineering \& Environmental Consultants, Austin, TX. 
Nickels, D.L.

2000 The Biesenbach Site (41WN88): a Case Study in Diet Breadth. Unpublished Master's Thesis, The University of Texas at San Antonio.

Nickels, D.L., D.W. Pease, and C.B. Bousman

1997 Archaeological Survey of Lackland Air Force Base, Bexar County, Texas. Archaeological Survey Report, No. 248. Center for Archaeological Research, The University of Texas at San Antonio.

Nickels, D.L., C.B. Bousman, J.D. Leach, and D.A. Cargill

2001 Test Excavations at the Culebra Creek Site, 41BX126, Bexar County, Texas. Archaeological Survey Report No. 265, Center for Archaeological Research, The University of Texas at San Antonio; Archeology Studies Program, Report 3, Environmental Affairs Division, Texas Department of Transportation, Austin.

Nickels, D.L., M.L. Lehman, C.B. Bousman

2003 Archaeological Evaluation of 39 Category V Sites at Camp Swift, Bastrop County, Texas: 2001. Archaeological Studies Report No. 3, Center for Archaeological Studies, Southwest Texas State University.

Nightengale, B.A., S.C. Caran, D.K. Utley, and H.G. Wooldridge

1992 Cultural Resource and Geomorphological Investigations at the Powell Bend II Lignite Prospect, Bastrop County, Texas. Cultural Resources Report No. 1, Lower Colorado River Authority, Environmental Services Department, Austin, TX.

Nightengale, B.A., and H.B. Moncure

1996 Intensive Cultural Resource Survey and Monitoring at the LCRA Camp Swift Regional Wastewater Project, Bastrop County, Texas. Cultural Resources Report No. 3, Lower Colorado River Authority, Environmental Protection Division, Austin.

Overalls

2003 Overalls, Present at the Creation. http://www.npr.org/programs/morning/features/patc/overalls/ Accessed 2:56 PM, December 3, 2003.

Patterson, L.W.

1988 Intergroup conflict in prehistoric Texas. Houston Archeological Society Journal 90:8-10.

1995 The archeology of Southeast Texas. Bulletin of the Texas Archeological Society 66:239-264.

Perttula, T.K.

1995 The archeology of the Pineywoods and Post Oak Savanna of Northeast Texas. Bulletin of the Texas Archeological Society 66:331-359, Austin.

Perttula, T.K., M.R. Miller, R.A. Ricklis, D.J. Prikryl, and C. Lintz

1995 Prehistoric and historic ceramics in Texas. Bulletin of the Texas Archeological Society 66:175-235, Austin. 
Perttula, T.K., B.D. Skiles, M.B. Collins, M.C. Trachte, and F. Valdez, Jr.

1986 "This Everlasting Sand Bed": Cultural Resources Investigations at the Texas Big Sandy Project, Wood and Upshur Counties, Texas. Reports of Investigations, Number 52. Prewitt and Associates, Inc., Austin.

Prewitt, E.R.

1974 Archeological Investigations at the Loeve-Fox Site, Williams County, Texas. Research Report 49. Texas Archeological Survey, The University of Texas at Austin.

1981 Culture chronology in Central Texas. Bulletin of the Texas Archeological Society 52:65-89.

1985 From Circleville to Toyah: comments on Central Texas chronology. Bulletin of the Texas Archeological Society 54:201-238.

1991 Burned rock middens: a summary of previous investigations and interpretations. In The Burned Rock Middens of Texas: An Archeological Symposium, edited T.R. Hester, pp. 25-32. Studies in Archeology 13. Texas Archeological Research Laboratory, The University of Texas at Austin.

Prochnow, S.

2001 Geoarchaeological assessment. In An Archaeological Inventory of Camp Swift, Bastrop County, Texas, pp. 31-37, edited by B.A. Meissner. Archaeological Survey Report Number 316, Center for Archaeological Research, The University of Texas at San Antonio.

Ricklis, R.A., and M.B. Collins (editors)

1994 Archaic and Late Prehistoric Human Ecology in the Middle Onion Creek Valley, Hays County, Texas, Volumes I-II. Studies in Archaeology 19. Texas Archeological Research Laboratory, The University of Texas at Austin.

Robinson, D.G.

2001 Historic contexts for Camp Swift. In An Archaeological Inventory of Camp Swift, Bastrop County, Texas, pp. 155-159, edited by B.A. Meissner. Archaeological Survey Report Number 316, Center for Archaeological Research, The University of Texas at San Antonio.

Robinson, D.G., T.M. Meade, L. Haslouer, L. Gassaway, and D. Kay

1997 State of Texas trinomial form, 41BP385. Copy on file, Texas Archeological Research Laboratory, University of Texas, Austin.

Robinson, D.G., T.M. Meade, L. Haslouer, L. Gassaway, and D. Kay

2001 An Archaeological Inventory of Camp Swift, Bastrop County, Texas, edited by B.A. Meissner. Archaeological Survey Report Number 316, Center for Archaeological Research, The University of Texas at San Antonio.

Robinson, R.L.

1979 Biosilica and climatic change at 41GD21 and 41GD21A. In Archaeological Investigations of Two Prehistoric Sites on the Coleto Creek Drainage, Goliad County, Texas, edited by D.E. Fox, pp. 102113. Archaeological Survey Report, No. 69. Center for Archaeological Research, The University of Texas at San Antonio.

1982 Biosilica analysis of three prehistoric archaeological sites in the Choke Canyon Reservoir, Live Oak County, Texas: preliminary summary of climatic implications. In Archaeological Investigations at Choke Canyon Reservoir, South Texas: The Phase I Findings, edited by G.D. Hall, S.L. Black, and C. 
Graves, pp. 597-610. Choke Canyon Series, No. 5. Center for Archaeological Research, The University of Texas at San Antonio.

Rogers, R.

1994 Excavations at site 41GM224 in the Gibbons Creek Lignite Mine Permit 38A Area, Grimes County, Texas. Espey, Huston \& Associates, Inc., Austin.

Rogers, R., and E. Foster

1994 National Register Assessment of Three Archaeological Sites at the Gibbons Creek Lignite Mine, Grimes County, Texas. Espey, Huston \& Associates, Inc., Austin.

Rogers, R., and S. Kotter

1995 Archaeological Investigations at the Chesser Site (41LE59), at the Sandow Lignite Mine, Lee County, Texas. Prepared for Aluminum Company of America (ALCOA) by Espey, Huston \& Associates, Inc., Austin, TX.

Sackett, J.R.

1988 Style and ethnicity in archaeology: the case for isochrestism. The Uses of Style in Archaeology, pp 32-43, edited by M. Conkey and C. Hastorf. Cambridge University Press.

Schmidt, J.S., and M.E. Cruse

1995 Cultural Resources Survey, Camp Swift, Bastrop County, Texas. Espey, Huston \& Associates, Inc., Austin.

Sellards, E.H.

1940 Pleistocene artifacts and associated fossils from Bee County, Texas. Bulletin of the Geological Society of America 51:1627-1658.

Sellards, E.H., W.S. Adkins, and F.B. Plummer

1932 The Geology of Texas: Volume I. Stratigraphy. Bulletin No. 3232. Bureau of Economic Geology, University of Texas, Austin.

Shafer, H.J.

1977 Art and territoriality in the Lower Pecos region. Plains Anthropologist 22:13-22.

Singer, M.J., and P. Fine

1989 Pedogenic factors affecting magnetic susceptibility of Northern California soils. Soil Science of America Journal 53:1119-1127.

Skelton, D.W., and M.D. Freeman

1979 A Cultural Resource Inventory and Assessment at Camp Swift, Texas. Report No. 72, Texas Archeological Survey, University of Texas at Austin.

Skinner, S.A.

1981 Aboriginal demographic changes in Central Texas. Plains Anthropologist 26(92):111-118. 
Simmons-Smith, M.D.

1989 Texas Glass: An Illustrated History of the Three Rivers Glass Company, 1922-1937. Atwood Printing, New Braunfels, Texas.

Smyrl, V.E.

2003 Oak Hill, Texas. The Handbook of Texas Online. http://www.tsha.edu/handbook/online/articles/view/ OO/hvo42.html [Accessed Fri Jan 16 10:13:14 US/Central 2004]

Soil Survey Division Staff

1993 Soil Survey Manual. U. S. Department of Agriculture Handbook Number 18. U.S. Government Printing Press, Washington, D.C.

Sollberger, J.B., and T.R. Hester

1972 The Strohacker Site: a review of pre-Archaic manifestations in Texas. Plains Anthropologist 17(58): 326-344.

Sorrow, W.M., H.J. Shafer, and R.E. Ross

1967 Excavations at Stillhouse Hollow Reservoir. Papers of the Texas Archeological Salvage Project, No. 11.

Steinbomer, R.A.

1982 Brickmaking in Texas: a history of the industry and its product. Unpublished manuscript submitted to the Texas Historical Commission, Austin.

Stevenson, M.G.

1991 Beyond the formation of hearth-associated artifact assemblages. In The Interpretation of Archaeological Spatial Patterning, edited by E.M. Kroll and T.D. Price, pp. 269-299. Plenium Press, New York.

Stockton, E.D.

1973 Shaw's Creek Shelter: human displacement of artifacts and its significance. Mankind 9:112-117.

1977 Review of early Bondaian dates. Mankind 11:48-51.

Story, D.A.

1985 Adaptive strategies of Archaic cultures of the west Gulf Coastal Plain. In Prehistoric Food Production in North America, edited by R. I. Ford, pp. 19-56. Anthropological Papers No. 75. Museum of Anthropology, University of Michigan, Ann Arbor.

1990 Cultural history of the Native Americans. The Archeology of the Gulf Coastal Plain: Volume 1, pp. 163-366. Arkansas Archeological Survey Research Series No. 38.

Stringer, S. S.,and A.J. Wormser

1996 Archeological Survey for Proposed Pond Improvements, Camp Swift Military Reservation, Bastrop County, Texas. Unpublished report by the Adjutant General's Department of Texas, Austin.

Suhm, D.A.

1957 Excavations at the Smith Rockshelter, Travis County, Texas. The Texas Journal of Science 9:26-58. 
Sullo, D.M., and A.J. Wormser

1996 Archeological Survey for Proposed Bradley Fighting Vehicle Training "Area A" at Camp Swift Military Reservation, Bastrop County, Texas. Unpublished report by The Adjutant General's Department of Texas, Austin.

Swanton, J.R.

1939 Final Report of the United States De Soto Expedition Commission. United States Printing Office, Washington, D.C.

Takac, P.R. and W.A. Gose,

1998 Magnetic susceptibility of sediments. In Wilson-Leonard, An 11,000-year Archeological Record of Hunter-gatherers in Central Texas, Volume IV: Archaeological Features and Technical Analyses, pp. 1329-1341, assembled and edited by M.B. Collins. Studies in Archeology 31, Texas Archeological Research Laboratory, the University of Texas at Austin; Archeological Studies Program, Report 10, Environmental Affairs Division, Texas Department of Transportation, Austin.

Taylor, A.J.

1987 Archaeological Survey of the CPS Butler Lignite Prospect, Bastrop and Lee Counties, Texas, 1984. Archaeological Survey Report, No. 151, Center for Archaeological Research, The University of Texas at San Antonio.

Tera Corporation

1978 Preliminary Drafts of Selected LCRA Inputs to BLM for Camp Swift Lignite Lease. Dallas.

Texas Genealogy

2003 http://www.rootsweb.com txbastro/1930s.htm. Accessed 11:37 AM, December 2, 2003.

Thoms, A.V. (editor)

1993 The Brazos Valley Slopes Archaeological Project: Cultural Resources Assessments for the Texas A\&M University Animal Science Teaching and Research Complex, Brazos County, Texas. Archaeological Research Laboratory, Reports of Investigations No. 14. Texas A\&M University, College Station.

Toulouse, J.H.

1971 Bottle Makers and Their Marks. Thomas Nelson Inc., New York.

Treece, A.C., J.M. Quigg, C. Lintz, and K.A. Miller

1991 Cultural Resource Investigations in the O. H. Ivie Reservoir, Concho, Coleman, and Runnels Counties, Texas. Volume IV: Data Recovery Results from Ceramic Sites, Technical Report No. 346-IV. Mariah Associates, Inc., Austin.

Turner, S.E., and T.R. Hester

1998 A Field Guide to Stone Artifacts of Texas Indians. Gulf Publishing Co, Houston. 
Vierra, B.

1998 Archaeological Investigations at 41MV120, Maverick County, Texas. Archaeological Survey

Report No. 251. Center for Archaeological research, The University of Texas at San Antonio.

Villa, P.

1982 Conjoinable pieces and site formation processes. American Antiquity 47(2):276-290.

Villa, P., and J. Courtin

1983 The interpretation of stratified sites: A View from Underground. Journal of Archaeological Science 10:267-281.

Waters, M.R.

1992 Principles of Geoarchaeology: a North American Perspective. The University of Arizona Press, Tucson.

Waters, M.R., and L.C. Nordt

1996 Geomorphic Reconnaissance of Selected Segments of the MidTexas Pipeline. In Archaeological Survey of the Proposed 130-Mile MidTexas Pipeline, Gonzales, Dewitt, Lavaca, Colorado, Austin, and Waller Counties, Texas. Report prepared by SWCA Environmental Consultants, Inc. for MidTexas Pipeline Company, April 1996, Austin.

Weir, F.A.

1976 The Central Texas Archaic. Unpublished Ph.D. dissertation. Anthropology Department, Washington State University.

Weissner, P.

1983 Style and social information in Kalahari San projectile points. American Antiquity 48(2):253-276.

Wenke, R.J.

1990 Patterns in Prehistory: Humankind's First Three Million Years. 3rd Edition. Oxford University Press, Oxford, England.

Weslowsky, A.B., T.R. Hester, and D.K. Brown

1976 Archeological investigations at the Jetta Court Site (41TV151) Travis County, Texas. Bulletin of the Texas Archeological Society 47:25-87.

Wilbarger, J.W.

1985 Indian Depredations in Texas: Original Narratives of Texas History and Adventure, 1885. Reprinted by Eakin Press, Austin.

Wilding, L.P.

2000 Classification of soils. In Handbook of Soil Science, pp. E-175 - E-392, edited by M.E. Summer. CRC Press, Boca Raton, Florida. 
Wilmarth, M.G. (compiler)

1938 Lexicon of Geologic Names of the United States (Including Alaska). Bulletin 896, Geological Survey, United States Department of the Interior, two volumes. United States Government Printing Office, Washington, D.C.

Wilson, A.M.

1930 Areal Survey of Travis, Bastrop and Fayette Counties. Report on file, Texas Archeological Research Laboratory, The University of Texas, Austin.

Winship, G.P.

1896 The Coronado expedition, 1540-1542. In Fourteenth Annual report of the Bureau of American Ethnology 1892-1893, Part I, pp. 339-637. Government Printing Office, Washington, D.C.

Wood, W.R., and D.L. Johnson

1978 A survey of disturbance processes in archaeological site formation. Advances in Archaeological Method and Theory, vol. 1, edited by M.B. Schiffer, pp. 315-381. Academic, New York.

Wormser, A.J.

1993a Archeological Survey of Proposed Tank Ditches at the Northwest Side of Scott Hill at Camp Swift, Bastrop County, Texas. Unpublished report by the Adjutant General's Department of Texas, Austin.

1993b Archeological Survey of a Proposed Septic Field East of the Blackwell Drop Zone at Camp Swift, Bastrop County, Texas. Unpublished report by the Adjutant General's Department of Texas, Austin.

1994 Archeological Survey for Rechannelization of a Stream at the M60 Range Firing Line at Camp Swift, Bastrop County, Texas. Unpublished report by the Adjutant General's Department of Texas, Austin.

Wormser, A.J., and C.M. Leshley

1995 Archeological Survey for the Proposed $386^{\text {th }}$ Engineer Battalion Annual Squad and Platoon Training at Camp Swift, Bastrop County, Texas. Unpublished report by the Adjutant General's Department of Texas, Austin.

Yellen, J.E.

1977 Archaeological Approaches to the Present: Models for Predicting the Past. Academic Press, New York.

Young, J.H.

1974 The Toadstool Millionaires: A Social History of Patent Medicines in America before Federal Regulation. Princeton University Press, New Jersey. 


\section{APPENDixA}

\section{Shovel Test Data}

David L. Nickels

\begin{tabular}{|c|c|c|c|c|c|c|c|c|c|}
\hline Area & ST & Positive? & Depth & Bottom & Area/Site & ST & Positive? & Depth & Bottom \\
\hline$A$ & $\overline{\mathrm{A} 1}$ & & 38 & Clay & $A$ & P2 & & 58 & Clay \\
\hline$A$ & $\mathrm{~A} 2$ & & 20 & Clay & A & P3 & Yes & 30 & Clay \\
\hline$A$ & B1 & & 60 & Clay & $A$ & Q1 & & 10 & Clay \\
\hline$A$ & B2 & & 70 & Clay & $A$ & Q2 & & 30 & Clay \\
\hline$A$ & B3 & & 10 & Clay & $A$ & Q3 & & 38 & Clay \\
\hline$A$ & C1 & & 50 & Clay & $A$ & R1 & & 30 & Clay \\
\hline$A$ & $\mathrm{C} 2$ & & 80 & Clay & $A$ & $\mathrm{R} 2$ & & 5 & Clay \\
\hline$A$ & $\mathrm{C} 3$ & & 30 & Clay & $A$ & R3 & & 50 & Clay \\
\hline$A$ & D1 & & 100 & Clay & $A$ & R4 & & 35 & Clay \\
\hline $\bar{A}$ & $\overline{D 2}$ & & 60 & Clay & $A$ & S1 & & 27 & Clay \\
\hline$A$ & D3 & & 20 & Clay & $A$ & S2 & & 35 & Clay \\
\hline $\bar{A}$ & D4 & & 30 & Clay & $\bar{A}$ & $\mathrm{~T} 1$ & & 50 & Clay \\
\hline $\bar{A}$ & $\mathrm{E} 1$ & & 28 & Clay & $A$ & $\mathrm{~T} 2$ & & 35 & Clay \\
\hline $\bar{A}$ & E2 & & 60 & Clay & $A$ & $\mathrm{U} 1$ & & 20 & Clay \\
\hline $\bar{A}$ & E3 & & 100 & Clay & $\bar{A}$ & $\mathrm{~V} 1$ & & 9 & Clay \\
\hline$A$ & $\overline{E 4}$ & & 30 & Clay & $A$ & V2 & & 55 & Clay \\
\hline $\bar{A}$ & F1 & & 27 & Clay & $A$ & W1 & & 38 & Clay \\
\hline$A$ & $\mathrm{~F} 2$ & & 70 & Clay & $A$ & $\mathrm{X} 1$ & & 40 & Clay \\
\hline$A$ & F3 & & 13 & Clay & $B$ & A1 & Yes & 105 & Clay \\
\hline $\bar{A}$ & F4 & & 20 & Clay & B & A2 & Yes & 100 & Sand \\
\hline$A$ & G1 & & 50 & Clay & B & A3 & & 45 & Clay \\
\hline $\bar{A}$ & G2 & & 55 & Clay & B & A4 & Yes & 55 & Clay \\
\hline $\bar{A}$ & G3 & & 10 & Clay & B & A5 & & 10 & Clay \\
\hline $\mathrm{A}$ & G4 & & 45 & Clay & $B$ & B1 & & 65 & Clay \\
\hline $\bar{A}$ & $\mathrm{H} 1$ & & 50 & Clay & B & B2 & & 20 & Clay \\
\hline$A$ & $\mathrm{H} 2$ & & 60 & Clay & $B$ & B3 & & 70 & Clay \\
\hline$A$ & $\mathrm{H} 3$ & & 30 & Clay & B & B4 & & 20 & Clay \\
\hline$A$ & $\mathrm{H} 4$ & & 25 & Clay & B & B5 & & 60 & Clay \\
\hline $\bar{A}$ & 11 & & 35 & Clay & $B$ & B6 & & 30 & Clay \\
\hline$A$ & 12 & & 10 & Clay & B & B7 & & 15 & Clay \\
\hline$A$ & 13 & & 25 & Clay & $B$ & $\mathrm{C} 1$ & & 50 & Clay \\
\hline$A$ & J1 & Yes & 50 & Clay & B & $\mathrm{C} 2$ & & 30 & Clay \\
\hline $\bar{A}$ & $\mathrm{~J} 2$ & & 20 & Clay & $B$ & C3 & & 50 & Clay \\
\hline$A$ & J3 & & 30 & Clay & $B$ & $\mathrm{C} 4$ & Yes & 60 & Clay \\
\hline$A$ & K1 & & 10 & Clay & $B$ & C5 & & 45 & Clay \\
\hline $\bar{A}$ & $\mathrm{~K} 2$ & & 25 & Clay & B & C6 & & 40 & Clay \\
\hline
\end{tabular}




\begin{tabular}{|c|c|c|c|c|c|c|c|c|c|}
\hline Area & ST & Positive? & Depth & Bottom & Area/Site & ST & Positive? & Depth & Bottom \\
\hline $\mathrm{A}$ & $\mathrm{K} 3$ & & 50 & Clay & B & $\overline{C 7}$ & & 35 & Clay \\
\hline $\bar{A}$ & L1 & & 10 & Clay & B & $\mathrm{C} 8$ & & 60 & Clay \\
\hline$A$ & $\mathrm{~L} 2$ & & 20 & Clay & $B$ & C9 & & 50 & Clay \\
\hline$A$ & L3 & & 40 & Clay & $B$ & D1 & & 30 & Clay \\
\hline $\bar{A}$ & M1 & & 15 & Clay & $B$ & $\overline{\mathrm{D} 2}$ & & 100 & Sand \\
\hline $\bar{A}$ & $\mathrm{M} 2$ & & 10 & Clay & B & D3 & Yes & 100 & Sand \\
\hline $\bar{A}$ & $\mathrm{M3}$ & & 20 & Clay & $\mathrm{B}$ & $\mathrm{E} 1$ & & 20 & Clay \\
\hline $\bar{A}$ & N1 & & 15 & Clay & $B$ & E2 & & 100 & Sand \\
\hline A & N2 & & 13 & Clay & B & E3 & & 50 & Clay \\
\hline $\bar{A}$ & N3 & & 100 & Clay & B & F1 & & 27 & Clay \\
\hline $\bar{A}$ & N4 & & 25 & Clay & $\bar{B}$ & $\bar{F} 2$ & & 50 & Clay \\
\hline $\bar{A}$ & 01 & & 48 & Clay & B & $\overline{\mathrm{G} 1}$ & & 20 & Clay \\
\hline $\bar{A}$ & $\mathrm{O} 2$ & & 60 & Clay & $B$ & G2 & & 100 & Sand \\
\hline $\bar{A}$ & $\mathrm{O} 3$ & & 55 & Clay & $B$ & $\mathrm{H} 1$ & & 60 & Clay \\
\hline $\bar{A}$ & $\mathrm{P} 1$ & & 25 & Clay & $\bar{B}$ & $\mathrm{H} 2$ & & 100 & Sand \\
\hline $\mathrm{B}$ & 11 & Yes & 55 & Clay & C & C30 & & 100 & Sand \\
\hline B & 12 & & 100 & Clay & $C$ & C31 & & 105 & Clay \\
\hline B & $\mathrm{J} 1$ & Yes & 47 & Clay & C & C32 & & 52 & Clay \\
\hline$B$ & $\mathrm{~J} 2$ & & 100 & Sand & $\mathrm{C}$ & C33 & & 70 & Clay \\
\hline $\bar{B}$ & J3 & Yes & 100 & Sand & $\mathrm{C}$ & C34 & & 20 & Clay \\
\hline$B$ & J4 & & 33 & Clay & $C$ & C35 & & 55 & Clay \\
\hline B & K1 & & 60 & Clay & $\bar{C}$ & C36 & & 100 & Clay \\
\hline $\mathrm{B}$ & $\mathrm{K} 2$ & & 30 & Clay & $\bar{C}$ & C37 & & 35 & Clay \\
\hline $\mathrm{B}$ & K3 & & 80 & Clay & $\bar{C}$ & C38 & Yes & 100 & Sand \\
\hline $\bar{B}$ & $\mathrm{~L} 1$ & & 50 & Clay & 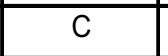 & C39 & & 100 & Sand \\
\hline$B$ & L2 & & 100 & Sand & C & $\mathrm{C} 4$ & & 25 & Clay \\
\hline$B$ & L3 & & 100 & Sand & C & C40 & & 25 & Clay \\
\hline$B$ & M1 & & 25 & Clay & C & C41 & & 28 & Clay \\
\hline$B$ & $\mathrm{M} 2$ & & 5 & Clay & C & C42 & & 100 & Sand \\
\hline$B$ & $\mathrm{M} 3$ & & 27 & Clay & $C$ & $\mathrm{C} 43$ & & 5 & Clay \\
\hline $\bar{B}$ & $\mathrm{~N} 1$ & & 16 & Clay & $\bar{C}$ & C44 & & 3 & Clay \\
\hline$B$ & N2 & & 50 & Clay & C & C45 & & 70 & Clay \\
\hline $\bar{B}$ & $\mathrm{~N} 3$ & & 20 & Clay & C & C46 & Yes & 100 & Sand \\
\hline B & 01 & & 25 & Clay & $\bar{C}$ & C47 & & 90 & Clay \\
\hline$B$ & $\mathrm{O} 2$ & Yes & 60 & Clay & $\bar{C}$ & C48 & & 20 & Clay \\
\hline$B$ & O3 & & 42 & Clay & C & C49 & & 80 & Clay \\
\hline$B$ & $\mathrm{P} 1$ & & 15 & Clay & C & $\mathrm{C5}$ & & 35 & Clay \\
\hline$B$ & $\mathrm{P} 2$ & & 25 & Clay & $\bar{C}$ & C50 & & 20 & Clay \\
\hline$B$ & $\mathrm{P} 3$ & & 10 & Clay & $C$ & C51 & & 95 & Clay \\
\hline B & Q1 & & 10 & Clay & C & C52 & & 18 & Clay \\
\hline$B$ & R1 & & 20 & Clay & C & C53 & & 100 & Sand \\
\hline B & $\mathrm{S1}$ & & 36 & Clay & $\bar{C}$ & C54 & & 70 & Clay \\
\hline
\end{tabular}




\begin{tabular}{|c|c|c|c|c|c|c|c|c|c|}
\hline Area & ST & Positive? & Depth & Bottom & Area/Site & ST & Positive? & Depth & Bottom \\
\hline$C$ & C1 & & 60 & Clay & $\mathrm{C}$ & C55 & & 20 & Clay \\
\hline $\bar{C}$ & $\mathrm{C} 10$ & & 47 & Clay & C & C56 & & 20 & Clay \\
\hline $\mathrm{C}$ & $\mathrm{C} 11$ & & 50 & Clay & $C$ & C57 & & 20 & Clay \\
\hline$C$ & $\mathrm{C} 12$ & & 80 & Clay & $C$ & C58 & & 7 & Clay \\
\hline C & C13 & & 90 & Clay & C & C59 & & 50 & Clay \\
\hline $\bar{C}$ & C14 & Yes & 80 & Clay & C & $\overline{C 6}$ & & 45 & Clay \\
\hline$C$ & C15 & Yes & 100 & Clay & $C$ & C60 & & 15 & Clay \\
\hline C & $\mathrm{C} 16$ & Yes & 100 & Sand & C & C61 & & 32 & Clay \\
\hline$C$ & C17 & & 40 & Clay & $C$ & C62 & & 20 & Clay \\
\hline $\bar{C}$ & C18 & & 35 & Clay & C & C63 & & 2 & Clay \\
\hline C & C19 & & 90 & Clay & C & C64 & & 20 & Clay \\
\hline C & $\mathrm{C} 2$ & & 30 & Clay & C & C65 & & 45 & Clay \\
\hline$C$ & $\mathrm{C} 20$ & & 80 & Clay & $C$ & $\mathrm{C} 7$ & Yes & 100 & Sand \\
\hline C & $\mathrm{C} 21$ & & 60 & Clay & C & $\mathrm{C} 8$ & Yes & 120 & Sand \\
\hline$C$ & $\mathrm{C} 22$ & Yes & 100 & Sand & $C$ & C9 & Yes & 100 & Sand \\
\hline C & $\mathrm{C} 23$ & Yes & 100 & Sand & $\bar{D}$ & $\mathrm{~A} 1$ & & 100 & Sand \\
\hline 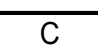 & $\mathrm{C} 24$ & & 20 & Clay & $\bar{D}$ & AA1 & & 100 & Sand \\
\hline$C$ & $\mathrm{C} 25$ & & 50 & Clay & $\bar{D}$ & $\overline{A A 2}$ & & 90 & Clay \\
\hline $\bar{C}$ & $\mathrm{C} 26$ & & 90 & Clay & $\mathrm{D}$ & $\overline{\mathrm{AA} 3}$ & & 45 & Clay \\
\hline C & $\mathrm{C} 27$ & & 50 & Clay & $\mathrm{D}$ & $\overline{A A 4}$ & & 20 & Clay \\
\hline $\bar{C}$ & $\mathrm{C} 28$ & Yes & 80 & Clay & $\bar{D}$ & AA5 & & 40 & Clay \\
\hline C & $\mathrm{C} 29$ & & 60 & Clay & $\bar{D}$ & $\mathrm{~B} 1$ & & 50 & Clay \\
\hline C & $\mathrm{C} 3$ & Yes & 35 & Clay & $\bar{D}$ & BB1 & & 100 & Sand \\
\hline $\bar{D}$ & BB2 & & 33 & Clay & $\bar{D}$ & S2 & & 90 & Sand \\
\hline $\bar{D}$ & BB3 & & 6 & Clay & $\bar{D}$ & S3 & & 100 & Sand \\
\hline $\bar{D}$ & $\mathrm{C} 1$ & & 70 & Clay & $\bar{D}$ & S4 & Yes & 35 & Clay \\
\hline $\bar{D}$ & $\mathrm{C} 2$ & & 100 & Sand & $\bar{D}$ & S5 & Yes & 100 & Sand \\
\hline $\bar{D}$ & $\overline{D 1}$ & & 67 & Clay & $\mathrm{D}$ & $\mathrm{T} 1$ & & 85 & Clay \\
\hline $\bar{D}$ & $\mathrm{E} 1$ & & 50 & Clay & $D$ & $\mathrm{~T} 2$ & & 70 & Clay \\
\hline $\bar{D}$ & F1 & & 90 & Clay & $\bar{D}$ & T3 & & 100 & Sand \\
\hline $\bar{D}$ & F2 & & 70 & Clay & $\bar{D}$ & $\mathrm{~T} 4$ & & 100 & Sand \\
\hline $\bar{D}$ & G1 & & 58 & Clay & $\bar{D}$ & T5 & & 100 & Sand \\
\hline $\bar{D}$ & $\mathrm{H} 1$ & & 70 & Clay & $\bar{D}$ & $\mathrm{U} 1$ & & 38 & Clay \\
\hline $\bar{D}$ & $\mathrm{H} 2$ & & 100 & Sand & $\bar{D}$ & $\mathrm{U} 2$ & Yes & 100 & Sand \\
\hline $\bar{D}$ & 11 & & 90 & Clay & $\bar{D}$ & U3 & & 100 & Sand \\
\hline $\bar{D}$ & $\mathrm{~J} 1$ & & 70 & Clay & $D$ & U4 & & 75 & Clay \\
\hline $\bar{D}$ & $\mathrm{~J} 2$ & Yes & 35 & Clay & $\bar{D}$ & U5 & & 100 & Sand \\
\hline $\bar{D}$ & $\mathrm{~J} 3$ & & 70 & Clay & $\bar{D}$ & U6 & & 65 & Clay \\
\hline $\bar{D}$ & $\mathrm{~J} 4$ & & 30 & Clay & $\bar{D}$ & V1 & & 40 & Clay \\
\hline $\bar{D}$ & $\mathrm{~J} 5$ & & 55 & Clay & $\mathrm{D}$ & $\overline{\mathrm{V} 2}$ & & 80 & Clay \\
\hline $\bar{D}$ & J6 & & 30 & Clay & $\bar{D}$ & V3 & & 100 & Sand \\
\hline$D$ & J7 & & 25 & Clay & $\bar{D}$ & V4 & & 100 & Sand \\
\hline
\end{tabular}




\begin{tabular}{|c|c|c|c|c|c|c|c|c|c|}
\hline Area & ST & Positive? & Depth & Bottom & Area/Site & ST & Positive? & Depth & Bottom \\
\hline $\mathrm{D}$ & K1 & & 100 & Sand & $\mathrm{D}$ & V5 & & 75 & Clay \\
\hline $\bar{D}$ & K2 & & 68 & Clay & $\bar{D}$ & V6 & & 93 & Clay \\
\hline $\bar{D}$ & K3 & & 49 & Clay & $\bar{D}$ & $\overline{\mathrm{W} 1}$ & & 45 & Clay \\
\hline $\bar{D}$ & $\overline{\mathrm{K} 4}$ & & 50 & Clay & $\bar{D}$ & $\overline{\mathrm{W} 2}$ & & 100 & Sand \\
\hline $\bar{D}$ & K5 & & 40 & Clay & $\bar{D}$ & W3 & & 100 & Sand \\
\hline $\bar{D}$ & $\overline{M 1}$ & & 26 & Clay & $\mathrm{D}$ & W4 & & 80 & Clay \\
\hline $\bar{D}$ & M2 & & 70 & Clay & $\mathrm{D}$ & W5 & & 60 & Clay \\
\hline $\bar{D}$ & $\mathrm{M} 3$ & & 100 & Sand & $\bar{D}$ & W6 & & 70 & Clay \\
\hline $\bar{D}$ & $\overline{M 4}$ & & 100 & Sand & $\bar{D}$ & $\mathrm{X1}$ & & 28 & Clay \\
\hline $\bar{D}$ & $\overline{\mathrm{N} 1}$ & & 28 & Clay & $\bar{D}$ & $\mathrm{X} 2$ & & 50 & Clay \\
\hline $\bar{D}$ & N2 & & 90 & Clay & $\bar{D}$ & $\mathrm{X3}$ & & 90 & Clay \\
\hline $\bar{D}$ & N3 & & 80 & Clay & $\mathrm{D}$ & $\overline{X 4}$ & & 100 & Clay \\
\hline $\bar{D}$ & 01 & & 100 & Sand & $\bar{D}$ & $\mathrm{X} 5$ & & 100 & Sand \\
\hline $\bar{D}$ & $\mathrm{O} 2$ & & 70 & Clay & $\bar{D}$ & $\mathrm{X6}$ & & 62 & Clay \\
\hline $\bar{D}$ & 03 & & 75 & Clay & $\bar{D}$ & $\mathrm{X7}$ & & 100 & Sand \\
\hline $\bar{D}$ & 04 & & 33 & Clay & $\bar{D}$ & $\overline{Y 1}$ & & 100 & Sand \\
\hline $\bar{D}$ & $\mathrm{P} 1$ & & 80 & Clay & $\mathrm{D}$ & Y2 & & 31 & Clay \\
\hline $\mathrm{D}$ & P2 & & 70 & Clay & $\mathrm{D}$ & $Y 3$ & & 100 & Sand \\
\hline $\bar{D}$ & $\mathrm{P3}$ & & 100 & Sand & $\mathrm{D}$ & $\mathrm{Y4}$ & & 100 & Sand \\
\hline $\bar{D}$ & $\overline{P 4}$ & & 58 & Clay & $\bar{D}$ & $\overline{Z 1}$ & & 20 & Clay \\
\hline $\bar{D}$ & $\overline{\mathrm{P} 5}$ & & 19 & Clay & $\bar{D}$ & $\overline{Z 2}$ & & 55 & Clay \\
\hline $\bar{D}$ & $\overline{\text { Q1 }}$ & & 65 & Clay & $\bar{D}$ & $\mathrm{Z3}$ & & 75 & Clay \\
\hline $\bar{D}$ & Q2 & & 100 & Sand & $\mathrm{D}$ & Z4 & & 90 & Clay \\
\hline $\bar{D}$ & Q3 & & 86 & Clay & $E$ & $\mathrm{E} 1$ & & 32 & Clay \\
\hline $\bar{D}$ & R1 & & 68 & Clay & $E$ & E10 & & 100 & Sand \\
\hline $\bar{D}$ & R2 & & 55 & Clay & $E$ & E11 & Yes & 20 & Clay \\
\hline $\bar{D}$ & R3 & & 100 & Clay & $\mathrm{E}$ & E12 & & 15 & Clay \\
\hline $\bar{D}$ & R4 & & 80 & Clay & $\mathrm{E}$ & E13 & & 10 & Clay \\
\hline $\bar{D}$ & R5 & & 86 & Clay & $E$ & E14 & & 2 & Clay \\
\hline $\bar{D}$ & $\mathrm{R} 6$ & & 95 & Clay & $E$ & E15 & & 5 & Clay \\
\hline $\bar{D}$ & $\overline{\mathrm{S} 1}$ & & 90 & Clay & $E$ & E16 & & 70 & Clay \\
\hline 41BP666 & 11 & & 10 & Clay & $\bar{G}$ & $\mathrm{G} 1$ & & 100 & Sand \\
\hline 41BP666 & 12 & & 15 & Clay & $\bar{G}$ & G10 & & 40 & Clay \\
\hline 41BP666 & 13 & & 15 & Clay & $\bar{G}$ & $\overline{\mathrm{G} 11}$ & & 100 & Clay \\
\hline 41BP666 & 14 & & 70 & Clay & $G$ & $\mathrm{G} 12$ & & 58 & Clay \\
\hline 41BP666 & 15 & Yes & 110 & Sand & $\bar{G}$ & $\overline{G 13}$ & & 60 & Clay \\
\hline 41BP666 & 16 & Yes & 110 & Sand & $\bar{G}$ & $\overline{\mathrm{G} 14}$ & & 90 & Clay \\
\hline 41BP666 & 17 & Yes & 100 & Sand & $\bar{G}$ & $\overline{\mathrm{G} 15}$ & & 100 & Clay \\
\hline 41BP666 & 18 & Yes & 110 & Sand & $\bar{G}$ & $\overline{G 16}$ & & 100 & Clay \\
\hline 41BP666 & 19 & & 100 & Sand & G & $\overline{G 17}$ & & 100 & Clay \\
\hline 41BP666 & 20 & Yes & 95 & Clay & $\bar{G}$ & $\overline{\mathrm{G} 18}$ & & 100 & Sand \\
\hline 41BP666 & 21 & & 68 & Clay & $\bar{G}$ & G19 & & 100 & Clay \\
\hline
\end{tabular}




\begin{tabular}{|c|c|c|c|c|c|c|c|c|c|}
\hline Area & ST & Positive? & Depth & Bottom & Area/Site & ST & Positive? & Depth & Bottom \\
\hline 41BP666 & 22 & & 10 & Clay & G & $\bar{G} 2$ & & 100 & Sand \\
\hline 41BP666 & 23 & & 28 & Clay & $G$ & $\mathrm{G} 20$ & & 70 & Clay \\
\hline 41BP666 & 24 & Yes & 100 & Sand & $\bar{G}$ & G21 & & 70 & Clay \\
\hline 41BP666 & 25 & Yes & 100 & Sand & $\bar{G}$ & $\bar{G} 22$ & & 100 & Clay \\
\hline 41BP666 & 26 & Yes & 90 & Clay & $\mathrm{G}$ & G3 & & 90 & Clay \\
\hline 41BP666 & 27 & Yes & 83 & Clay & $\mathrm{G}$ & G4 & & 40 & Clay \\
\hline 41BP666 & 28 & Yes & 100 & Clay & $\bar{G}$ & G5 & & 90 & Clay \\
\hline 41BP666 & 29 & Yes & 100 & Clay & $\bar{G}$ & $\overline{\mathrm{G} 6}$ & & 70 & Clay \\
\hline 41BP666 & 30 & Yes & 90 & Clay & $\bar{G}$ & $\overline{G 7}$ & & 56 & Clay \\
\hline 41BP666 & 31 & & 100 & Sand & $\bar{G}$ & G8 & & 80 & Clay \\
\hline 41BP666 & 32 & Yes & 100 & Sand & $\bar{G}$ & G9 & & 55 & Clay \\
\hline 41BP666 & 33 & & 100 & Clay & $\mathrm{H}$ & $\overline{\mathrm{A} 1}$ & & 100 & Sand \\
\hline 41BP666 & 34 & Yes & 50 & Clay & $\overline{\mathrm{H}}$ & $\bar{A} 2$ & Yes & 110 & Sand \\
\hline 41BP666 & 35 & Yes & 35 & Clay & $\mathrm{H}$ & $\mathrm{B} 1$ & Yes & 100 & Sand \\
\hline 41BP666 & 36 & & 70 & Clay & $\mathrm{H}$ & B2 & Yes & 100 & Sand \\
\hline 41BP666 & 37 & Yes & 30 & Clay & $\mathrm{H}$ & $\mathrm{C} 1$ & & 100 & Sand \\
\hline 41BP667 & 1 & Yes & 70 & Clay & $\mathrm{H}$ & $\mathrm{C} 2$ & & 100 & Sand \\
\hline 41BP667 & 2 & Yes & 70 & Clay & $\mathrm{H}$ & $\mathrm{D} 1$ & & 50 & Clay \\
\hline 41BP667 & 3 & Yes & 70 & Clay & $\mathrm{H}$ & D2 & & 100 & Sand \\
\hline 41BP667 & 4 & & 60 & Clay & $\mathrm{H}$ & E1 & & 100 & Sand \\
\hline 41BP667 & 5 & & 65 & Clay & $\bar{H}$ & E2 & & 100 & Sand \\
\hline 41BP667 & 6 & & 65 & Clay & $\mathrm{H}$ & F1 & & 100 & Sand \\
\hline 41BP667 & 7 & & 65 & Clay & $\mathrm{H}$ & F2 & & 100 & Sand \\
\hline 41BP667 & 8 & Yes & 50 & Clay & $\bar{H}$ & G1 & & 100 & Sand \\
\hline $\mathrm{H}$ & $\mathrm{H} 1$ & & 15 & Clay & 1 & $\bar{L} 5$ & & 100 & Sand \\
\hline 1 & $\bar{A} 1$ & & 70 & Clay & I & M1 & & 20 & Clay \\
\hline $\mathrm{I}$ & A2 & & 16 & Clay & I & M2 & & 70 & Clay \\
\hline 1 & A3 & & 68 & Clay & I & M3 & & 100 & Clay \\
\hline 1 & $\overline{\mathrm{A} 4}$ & & 47 & Clay & $\mathrm{I}$ & $\mathrm{M} 4$ & & 67 & Clay \\
\hline I & A5 & & 23 & Clay & I & M5 & & 50 & Clay \\
\hline $\mathrm{I}$ & $\overline{A A 1}$ & & 40 & Clay & I & $\mathrm{N} 1$ & & 10 & Clay \\
\hline $\mathrm{I}$ & B1 & & 100 & Sand & I & N2 & & 40 & Clay \\
\hline $\mathrm{I}$ & B2 & & 50 & Clay & $\mathrm{I}$ & N3 & & 80 & Clay \\
\hline $\mathrm{I}$ & B3 & & 100 & Sand & I & N4 & Yes & 90 & Clay \\
\hline $\mathrm{I}$ & B4 & Yes & 70 & Clay & I & N5 & & 100 & Sand \\
\hline $\mathrm{I}$ & B5 & & 50 & Clay & I & 01 & & 50 & Clay \\
\hline I & $\mathrm{B} 6$ & & 40 & Clay & I & $\mathrm{O} 2$ & & 100 & Clay \\
\hline $\mathrm{I}$ & BB1 & & 100 & Sand & I & O3 & & 100 & Clay \\
\hline I & BB2 & & 45 & Clay & I & $\mathrm{O4}$ & & 45 & Clay \\
\hline $\mathrm{I}$ & $\mathrm{C} 1$ & & 45 & Clay & I & $\mathrm{P} 1$ & & 85 & Clay \\
\hline I & $\mathrm{C} 2$ & & 75 & Clay & I & $\mathrm{P} 2$ & & 20 & Clay \\
\hline$I$ & C3 & & 100 & Sand & $I$ & $\mathrm{P} 3$ & & 50 & Clay \\
\hline
\end{tabular}




\begin{tabular}{|c|c|c|c|c|c|c|c|c|c|}
\hline Area & ST & Positive? & Depth & Bottom & Area/Site & ST & Positive? & Depth & Bottom \\
\hline 1 & $\mathrm{C} 4$ & & 70 & Clay & 1 & $\mathrm{P} 4$ & & 50 & Clay \\
\hline $\mathrm{I}$ & D1 & & 65 & Clay & $\mathrm{I}$ & Q1 & & 38 & Clay \\
\hline$T$ & D2 & & 100 & Sand & $T$ & Q2 & & 47 & Clay \\
\hline$T$ & D3 & & 88 & Clay & $T$ & Q3 & & 90 & Clay \\
\hline$T$ & D4 & & 100 & Clay & $T$ & $\overline{Q 4}$ & & 10 & Clay \\
\hline $\mathrm{I}$ & $\overline{E 1}$ & & 100 & Sand & $\mathrm{I}$ & R1 & & 100 & Clay \\
\hline $\mathrm{I}$ & E2 & & 100 & Sand & 1 & R2 & & 46 & Clay \\
\hline$T$ & E3 & & 60 & Clay & $T$ & S1 & & 40 & Clay \\
\hline $\mathrm{I}$ & $\overline{F 1}$ & & 100 & Sand & $\mathrm{I}$ & S2 & & 60 & Clay \\
\hline $\mathrm{I}$ & F2 & & 100 & Sand & I & $\mathrm{T} 1$ & & 80 & Clay \\
\hline $\mathrm{I}$ & F3 & & 100 & Sand & I & $\mathrm{T} 2$ & & 40 & Clay \\
\hline $\mathrm{I}$ & G1 & Yes & 100 & Sand & $\mathrm{I}$ & $\mathrm{U} 1$ & & 68 & Clay \\
\hline$T$ & G2 & Yes & 100 & Sand & $T$ & $\mathrm{U} 2$ & & 38 & Clay \\
\hline $\mathrm{I}$ & G3 & & 100 & Clay & $\mathrm{I}$ & V1 & & 60 & Clay \\
\hline $\mathrm{I}$ & $\mathrm{H} 1$ & & 100 & Sand & $\mathrm{I}$ & V2 & & 100 & Sand \\
\hline $\mathrm{I}$ & $\mathrm{H} 2$ & Yes & 110 & Sand & $\mathrm{I}$ & $\overline{W 1}$ & & 100 & Sand \\
\hline $\mathrm{I}$ & $\mathrm{H} 3$ & & 25 & Clay & $\mathrm{I}$ & $\mathrm{X} 1$ & & 50 & Clay \\
\hline 1 & 11 & & 100 & Sand & $\mathrm{I}$ & $\mathrm{Y1}$ & & 100 & Sand \\
\hline $\mathrm{I}$ & 12 & Yes & 100 & Sand & $\mathrm{I}$ & $\mathrm{Z1}$ & & 90 & Clay \\
\hline $\mathrm{I}$ & 13 & Yes & 110 & Sand & $\mathrm{J}$ & 39 & & 35 & Clay \\
\hline $\mathrm{I}$ & J1 & & 100 & Sand & $\mathrm{J}$ & 40 & & 40 & Clay \\
\hline $\mathrm{I}$ & $\mathrm{J} 2$ & & 100 & Sand & $\mathrm{J}$ & 41 & & 40 & Clay \\
\hline $\mathrm{I}$ & J3 & & 100 & Sand & $\mathrm{J}$ & 42 & & 35 & Clay \\
\hline $\mathrm{I}$ & $\mathrm{J} 4$ & & 50 & Clay & $\mathrm{J}$ & J1 & & 28 & Clay \\
\hline $\mathrm{I}$ & K1 & Yes & 100 & Sand & $\mathrm{J}$ & $\mathrm{J} 10$ & & 35 & Clay \\
\hline $\mathrm{I}$ & $\mathrm{K} 2$ & & 30 & Clay & $\mathrm{J}$ & $\mathrm{J} 11$ & & 20 & Clay \\
\hline $\mathrm{I}$ & K3 & & 85 & Clay & $\mathrm{J}$ & $\mathrm{J} 12$ & & 20 & Clay \\
\hline $\mathrm{I}$ & $\mathrm{K} 4$ & & 55 & Clay & $\mathrm{J}$ & J13 & & 50 & Clay \\
\hline $\mathrm{I}$ & $\mathrm{L} 1$ & & 50 & Clay & $\mathrm{J}$ & J14 & Yes & 70 & Clay \\
\hline $\mathrm{I}$ & L2 & & 50 & Clay & $\mathrm{J}$ & J15 & & 80 & Clay \\
\hline $\mathrm{I}$ & $\bar{L} 3$ & & 30 & Clay & $\mathrm{J}$ & $\mathrm{J} 16$ & & 40 & Clay \\
\hline$I$ & L4 & & 100 & Sand & $\mathrm{J}$ & J17 & & 100 & Sand \\
\hline $\mathrm{J}$ & $\mathrm{J} 18$ & & 37 & Clay & $\bar{K}$ & F1 & & 85 & Clay \\
\hline $\mathrm{J}$ & J19 & & 90 & Clay & $\bar{K}$ & F2 & & 100 & Sand \\
\hline $\mathrm{J}$ & $\mathrm{J} 2$ & & 60 & Clay & $\bar{K}$ & F3 & & 75 & Clay \\
\hline $\mathrm{J}$ & $\mathrm{J} 20$ & & 100 & Clay & $\bar{K}$ & F4 & & 60 & Clay \\
\hline $\mathrm{J}$ & $\mathrm{J} 21$ & & 100 & Sand & $\mathrm{K}$ & $\overline{G 1}$ & & 80 & Clay \\
\hline $\mathrm{J}$ & J22 & & 100 & Sand & $\mathrm{K}$ & $\overline{\mathrm{G} 2}$ & & 70 & Clay \\
\hline $\mathrm{J}$ & $\mathrm{J} 23$ & & 100 & Sand & $\bar{K}$ & G3 & & 80 & Clay \\
\hline $\mathrm{J}$ & J24 & & 45 & Clay & $\bar{K}$ & $\mathrm{H} 1$ & & 75 & Clay \\
\hline $\mathrm{J}$ & $\mathrm{J} 25$ & & 100 & Sand & $\mathrm{K}$ & $\mathrm{H} 2$ & & 45 & Clay \\
\hline $\mathrm{J}$ & $\mathrm{J} 26$ & & 38 & Clay & $\bar{K}$ & $\mathrm{H} 3$ & & 65 & Clay \\
\hline
\end{tabular}




\begin{tabular}{|c|c|c|c|c|c|c|c|c|c|}
\hline Area & ST & Positive? & Depth & Bottom & Area/Site & ST & Positive? & Depth & Bottom \\
\hline$J$ & J27 & & 80 & Clay & $\mathrm{K}$ & 11 & Yes & 30 & Clay \\
\hline $\mathrm{J}$ & J28 & & 10 & Clay & $\mathrm{K}$ & 12 & & 33 & Clay \\
\hline $\mathrm{J}$ & $\mathrm{J} 29$ & & 80 & Clay & $\mathrm{K}$ & J1 & & 20 & Clay \\
\hline $\mathrm{J}$ & J3 & & 10 & Clay & $\mathrm{K}$ & $\mathrm{J} 2$ & & 20 & Clay \\
\hline $\mathrm{J}$ & $\mathrm{J} 30$ & & 28 & Clay & $\bar{K}$ & $\mathrm{~K} 1$ & & 25 & Clay \\
\hline $\mathrm{J}$ & J31 & & 80 & Clay & $\mathrm{K}$ & $\mathrm{L} 1$ & & 15 & Clay \\
\hline $\mathrm{J}$ & $\mathrm{J} 32$ & Yes & 30 & Clay & 41BP663 & 1 & & 60 & Clay \\
\hline $\mathrm{J}$ & $\mathrm{J} 33$ & & 95 & Clay & 41BP663 & 2 & & 55 & Clay \\
\hline $\mathrm{J}$ & $\mathrm{J} 34$ & & 27 & Clay & 41BP663 & 3 & Yes & 70 & Clay \\
\hline $\mathrm{J}$ & $\mathrm{J} 35$ & & 60 & Clay & 41BP663 & 4 & Yes & 75 & Clay \\
\hline $\mathrm{J}$ & $\mathrm{J} 36$ & & 79 & Clay & 41BP663 & 5 & & 65 & Clay \\
\hline $\mathrm{J}$ & J37 & & 100 & Sand & 41BP663 & 6 & Yes & 88 & Clay \\
\hline $\mathrm{J}$ & $\mathrm{J} 38$ & & 50 & Clay & 41BP663 & 7 & Yes & 60 & Clay \\
\hline $\mathrm{J}$ & $\mathrm{J} 4$ & & 85 & Clay & 41BP664 & 1 & Yes & 30 & Clay \\
\hline $\mathrm{J}$ & J5 & & 100 & Sand & 41BP664 & 2 & Yes & 36 & Clay \\
\hline $\mathrm{J}$ & J6 & & 80 & Clay & 41BP664 & 3 & Yes & 45 & Clay \\
\hline $\mathrm{J}$ & J7 & & 12 & Clay & 41BP664 & 4 & Yes & 60 & Clay \\
\hline $\mathrm{J}$ & J8 & & 10 & Clay & 41BP664 & 5 & Yes & 25 & Clay \\
\hline $\mathrm{J}$ & J9 & & 18 & Clay & 41BP664 & 6 & Yes & 80 & Clay \\
\hline $\bar{K}$ & $\bar{A} 1$ & & 40 & Clay & 41BP664 & 7 & & 15 & Clay \\
\hline $\mathrm{K}$ & $\bar{A} 2$ & & 70 & Clay & 41BP664 & 8 & & 20 & Clay \\
\hline $\mathrm{K}$ & $\mathrm{A} 3$ & & 71 & Clay & 41BP664 & 9 & Yes & 40 & Clay \\
\hline $\mathrm{K}$ & B1 & & 65 & Clay & 41BP664 & 10 & & 50 & Clay \\
\hline $\mathrm{K}$ & B2 & & 75 & Clay & 41BP664 & 11 & Yes & 20 & Clay \\
\hline $\mathrm{K}$ & B3 & & 80 & Clay & 41BP664 & 12 & & 60 & Clay \\
\hline $\mathrm{K}$ & C1 & & 95 & Clay & 41BP664 & 13 & Yes & 35 & Clay \\
\hline $\bar{K}$ & $\mathrm{C} 2$ & & 95 & Clay & 41BP665 & 1 & Yes & & \\
\hline $\mathrm{K}$ & $\mathrm{C3}$ & & 90 & Clay & 41BP665 & 2 & Yes & & \\
\hline $\mathrm{K}$ & D1 & & 90 & Clay & 41BP665 & 3 & Yes & & \\
\hline $\mathrm{K}$ & $\mathrm{D} 2$ & & 80 & Clay & 41BP665 & 4 & & 100 & Clay \\
\hline $\mathrm{K}$ & D3 & & 70 & Clay & 41BP665 & 5 & Yes & & \\
\hline $\mathrm{K}$ & D4 & & 100 & Clay & 41BP665 & 6 & & 60 & Clay \\
\hline $\mathrm{K}$ & E1 & Yes & 95 & Clay & 41BP665 & 7 & Yes & & \\
\hline $\mathrm{K}$ & E2 & & 85 & Clay & 41BP665 & 8 & Yes & & \\
\hline $\mathrm{K}$ & E3 & & 75 & Clay & 41BP667 & 9 & & 75 & Clay \\
\hline $\mathrm{K}$ & E4 & & 100 & Clay & 41BP668 & 1 & Yes & 30 & Clay \\
\hline $\mathrm{K}$ & E5 & & 95 & Clay & 41BP668 & 2 & Yes & 30 & Clay \\
\hline $\mathrm{K}$ & E6 & & 100 & Clay & 41BP668 & 3 & Yes & 25 & Clay \\
\hline $\mathrm{K}$ & E7 & & 95 & Clay & 41BP669 & 1 & Yes & 105 & Clay \\
\hline \multirow[t]{3}{*}{$\mathrm{K}$} & E8 & & 80 & Clay & 41BP669 & 2 & & 80 & Sand \\
\hline & & & & & 41BP669 & 3 & & 105 & Sand \\
\hline & & & & & 41BP669 & 4 & & 110 & Sand \\
\hline
\end{tabular}




\begin{tabular}{|c|c|c|c|c|c|c|c|c|c|}
\hline Area & ST & Positive? & Depth & Bottom & Area/Site & ST & Positive? & Depth & Bottom \\
\hline & & & & & 41BP669 & 5 & & 100 & Sand \\
\hline & & & & & 41BP669 & 6 & Yes & 100 & Sand \\
\hline & & & & & 41BP669 & 7 & Yes & 100 & Sand \\
\hline & & & & & 41BP670 & 1 & & 5 & Clay \\
\hline & & & & & 41BP670 & 2 & & 10 & Clay \\
\hline & & & & & 41BP670 & 3 & & 8 & Clay \\
\hline & & & & & 41BP670 & 4 & & 5 & Clay \\
\hline & & & & & 41BP671 & 8 & & 85 & Clay \\
\hline & & & & & 41BP671 & 9 & & 100 & Sand \\
\hline & & & & & 41BP671 & 10 & Yes & 100 & Sand \\
\hline & & & & & 41BP671 & 11 & & 100 & Sand \\
\hline & & & & & 41BP671 & 12 & Yes & 100 & Sand \\
\hline & & & & & 41BP671 & 13 & & 100 & Sand \\
\hline & & & & & 41BP671 & 14 & Yes & 100 & Sand \\
\hline & & & & & 41BP671 & 15 & & 60 & Clay \\
\hline & & & & & 41BP671 & 16 & Yes & 110 & Sand \\
\hline & & & & & 41BP671 & 17 & Yes & 80 & Clay \\
\hline & & & & & 41BP671 & 18 & Yes & 100 & Sand \\
\hline & & & & & 41BP671 & 19 & & 100 & Sand \\
\hline & & & & & 41BP671 & 20 & Yes & 100 & Sand \\
\hline & & & & & 41BP671 & 21 & & 75 & Clay \\
\hline & & & & & 41BP671 & 22 & & 70 & Clay \\
\hline & & & & & 41BP671 & 23 & & 30 & Clay \\
\hline & & & & & 41BP671 & 24 & & 70 & Clay \\
\hline & & & & & 41BP671 & 25 & & 33 & Clay \\
\hline & & & & & 41BP671 & 26 & Yes & 70 & Clay \\
\hline & & & & & 41BP671 & 27 & & 60 & Clay \\
\hline & & & & & 41BP671 & 28 & Yes & 60 & Clay \\
\hline & & & & & 41BP672 & 1 & Yes & 42 & Bedrock \\
\hline
\end{tabular}


APENDIX B. REDACTED 